\title{
Surface-Water-Quality Assessment of
}

the Lower Kansas River Basin, Kansas and Nebraska-Results of Investigations, 1987-90

National Water-Quality Assessment

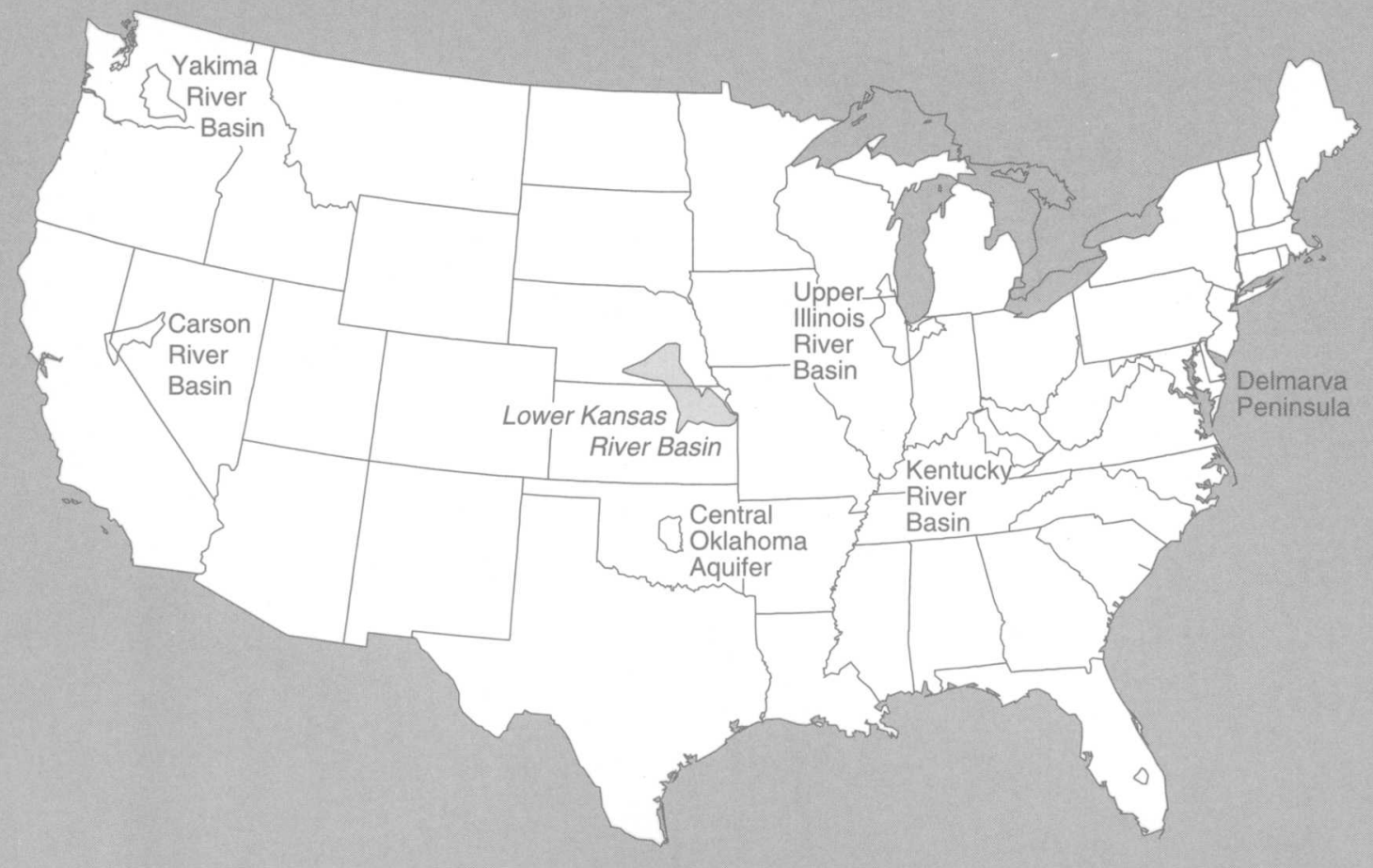

\section{United States}

\section{Geological}

Survey

Water-Supply

Paper 2451

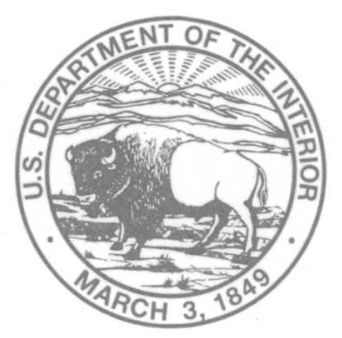




\section{AVAILABILITY OF BOOKS AND MAPS OF THE U.S. GEOLOGICAL SURVEY}

Instructions on ordering publications of the U.S. Geological Survey, along with prices of the last offerings, are given in the currentyear issues of the monthly catalog "New Publications of the U.S. Geological Survey." Prices of available U.S. Geological Survey publications released prior to the current year are listed in the most recent annual "Price and Availability List." Publications that may be listed in various U.S. Geological Survey catalogs (see back inside cover) but not listed in the most recent annual "Price and Availability List" may be no longer available.

Order U.S. Geological Survey publications by mail or over the counter from the offices given below.

\section{BY MAIL}

\section{Books}

Professional Papers, Bulletins, Water-Supply Papers, Techniques of Water-Resources Investigations, Circulars, publications of general interest (such as leaflets, pamphlets, booklets), single copies of Earthquakes \& Volcanoes, Preliminary Determination of Epicenters, and some miscellaneous reports, including some of the foregoing series that have gone out of print at the Superintendent of Documents, are obtainable by mail from

U.S. Geological Survey, Information Services

Box 25286, Federal Center, Denver, CO 80225

Subscriptions to periodicals (Earthquakes \& Volcanoes and Preliminary Determination of Epicenters) can be obtained ONLY from the

\section{Superintendent of Documents \\ Government Printing Office \\ Washington, DC 20402}

(Check or money order must be payable to Superintendent of Documents.)

\section{Maps}

For maps, address mail orders to

U.S. Geological Survey, Information Services Box 25286, Federal Center, Denver, CO 80225

\section{OVER THE COUNTER}

\section{Books and Maps}

Books and maps of the U.S. Geological Survey are available over the counter at the following U.S. Geological Survey Earth Science Information Centers (ESIC), all of which are authorized agents of the Superintendent of Documents:

- ANCHORAGE, Alaska-Rm. 101, 4230 University Dr.

- LAKEWOOD, Colorado-Federal Center, Bldg. 810

- MENLO PARK, California-Bldg. 3, Rm. 3128, 345 Middlefield Rd.

- RESTON, Virginia_USGS National Center, Rm. 1C402, 12201 Sunrise Valley Dr.

- SALT LAKE CITY, Utah-Federal Bldg., Rm. 8105, 125 South State St.

- SPOKANE, Washington-U.S. Post Office Bldg., Rm. 135, West 904 Riverside Ave.

- WASHINGTON, D.C.-Main Interior Bldg., Rm. 2650, 18th and C Sts., NW.

\section{Maps Only}

Maps may be purchased over the counter at the following U.S. Geological Survey offices:

- ROLLA, Missouri-1400 Independence Rd.

- STENNIS SPACE CENTER, Mississippi-Bldg. 3101 
Surface-Water-Quality Assessment of the

Lower Kansas River Basin, Kansas and

Nebraska: Results of Investigations, 1987-90

Edited by J.O. HELGESEN 


\title{
U.S. DEPARTMENT OF THE INTERIOR BRUCE BABBITT, Secretary
}

\author{
U.S. GEOLOGICAL SURVEY \\ GORDON P. EATON, Director
}

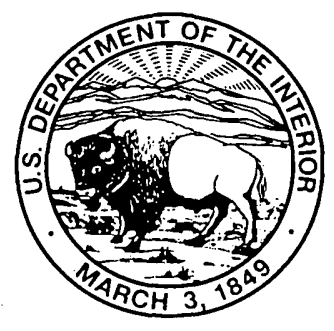

Any use of trade, product, or firm names in this publication is for descriptive purposes only and does not imply endorsement by the U.S. Government.

For sale by the

U.S. Geological Survey

Information Services

Box 25286, Federal Center

Denver, CO 80225

\section{Library of Congress Cataloging in Publication Data}

Surface-water-quality assessment of the lower Kansas river basin, Kansas and Nebraska : results of investigations, 1987-90 / edited by J.O. Helgensen.

p. $\quad$ cm. - (U.S. Geological Survey water supply paper ; 2451)

Includes bibliographical references ( $p$. ').

1. Water quality-Kansas-Kansas River Watershed. I. Helgensen, John O.

II. Series.

TD 224.K3S87 1996

363.73' 942 '097813-dc20 


\section{CONTENTS}

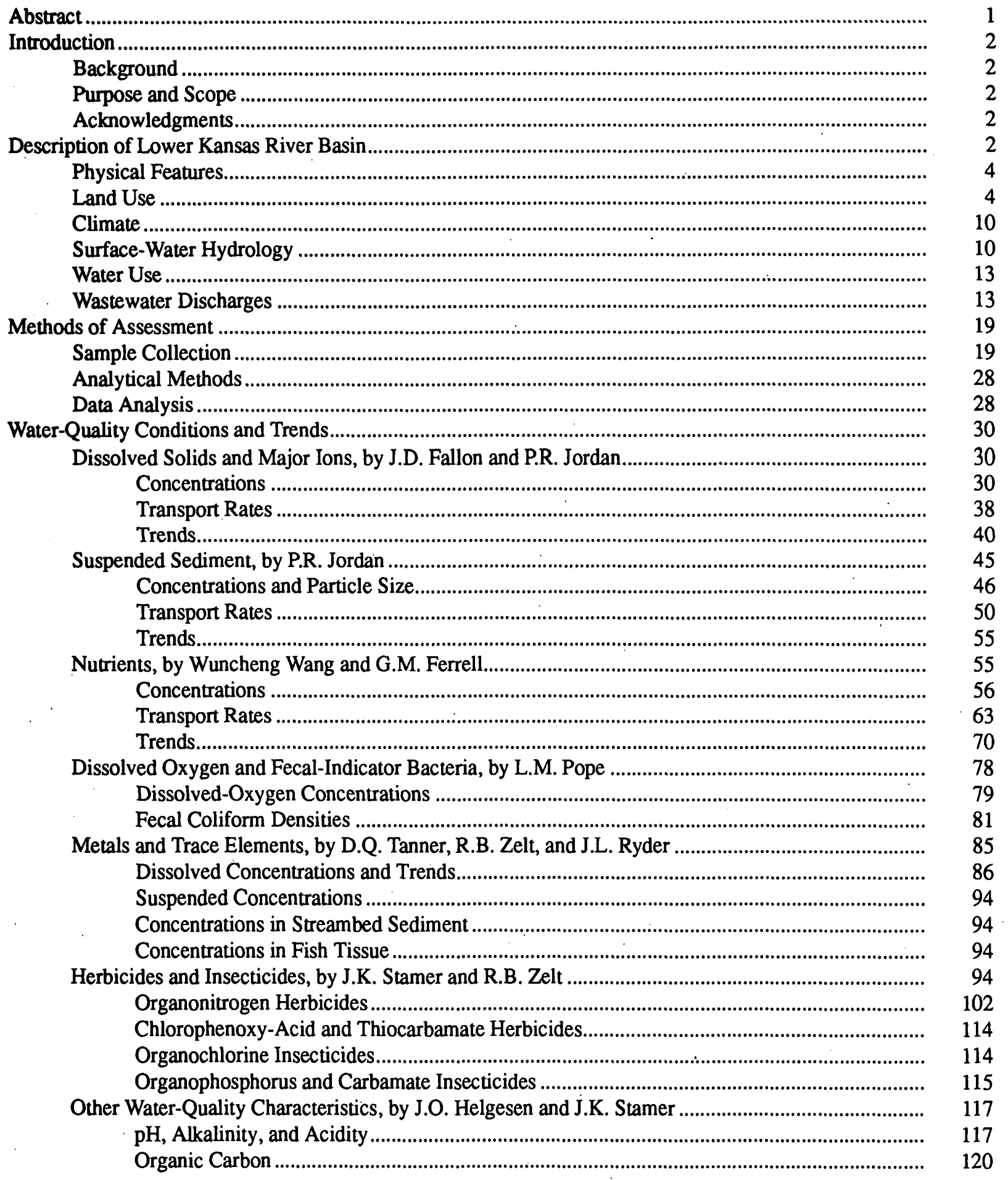




\section{CONTENTS-Continued}

Water-Quality Conditions and Trends-Continued

Other Water-Quality Characteristics, by J.O. Helgesen and J.K. Stamer-Continued

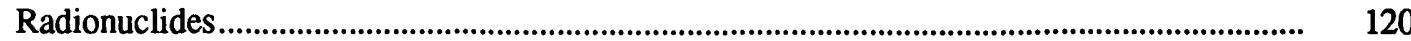

Summary

References Cited

\section{FIGURES}

1-6. Maps showing:

1. Major streams, surface-water impoundments, cities, and other geographic features in and near lower Kansas River Basin, Kansas and Nebraska.

2. Physiographic sections of lower Kansas River Basin.......................................................................

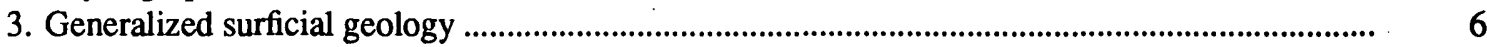

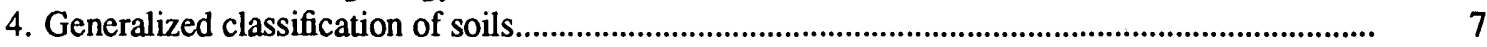

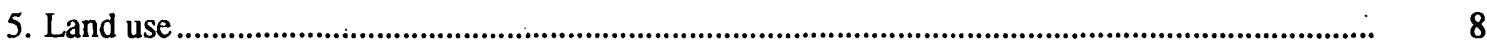

6. Cropland removed from production within lower Kansas River Basin, by county, due to implementation of Conservation Reserve Program, 1986-90

7. Map and graph showing mean annual precipitation, May 1987-April 1990, and departures from 1951-80 mean

8-11. Map showing:

8. Mean annual runoff, May 1987-April 1990, and departure from 1951-80 mean.............................. 14

9. Location of fixed- and synoptic-sampling stations, May 1987-April 1990 ................................... 17

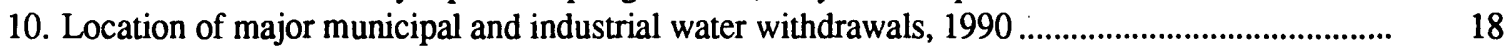

11. Location of major industrial and municipal permitted wastewater discharges, 1990 ...................... 20

12-15. Graphs showing:

12. Median concentrations of selected dissolved major ions in water at fixed stations in lower Kansas River Basin, Kansas and Nebraska, May 1987-April 1990

13. Distribution of dissolved-chloride concentrations in water at fixed stations in lower Kansas River Basin, Kansas and Nebraska, May 1987-April 1990

14. Distribution of suspended-sediment concentrations in lower Kansas River Basin, Kansas and Nebraska, May 1987-April 1990.

15. (A) Definition of and $(B)$ bimonthly departures from relation between suspendedsediment concentration and streamflow rate in lower Kansas River Basin, Kansas and Nebraska, May 1987-April 1990.

16. Map showing mean annual transport rates of suspended sediment in lower Kansas River Basin, Kansas and Nebraska, May 1987-April 1990

17. Diagrams showing sources and estimated annual amounts of $(A)$ total nitrogen and $(B)$ total phosphorus in lower Kansas River Basin, Kansas and Nebraska, 1987-90.

18. Map showing concentrations of dissolved nitrite plus nitrate, as nitrogen, in water at synopticsampling stations, November 1988

19. Map showing concentrations of total ammonia plus organic nitrogen, as nitrogen, in water at synoptic-sampling stations, November 1988

20. Graphs showing seasonal variations in concentrations of dissolved nitrite plus nitrate, as nitrogen, in water at selected fixed stations in lower Kansas River Basin, Kansas and Nebraska, May 1987-April 1990.

21. Graphs showing seasonal variations in concentrations of dissolved ammonia, as nitrogen, in water at selected fixed stations in lower Kansas River Basin, Kansas and Nebraska, May 1987April 1990

22. Map showing concentrations of total phosphorus in water at synoptic-sampling stations, November 1988 . 


\section{FIGURES-Continued}

23. Graphs showing seasonal variations in concentrations of total phosphorus in water at selected fixed stations in lower Kansas River Basin, Kansas and Nebraska, May 1987-April 1990

24. Map showing predawn instantancous dissolved-oxygen concentrations, July 24-29, 1988, and location of municipal wastewater-treatment plants with permitted discharges of 1.0 million gallons per day or more.

25. Graphs showing diel variability of dissolved-oxygen concentrations in water at selected synopticsampling stations in lower Kansas River Basin, Kansas and Nebraska, July 24-29, 1988

26. Map showing instantancous densities of Escherichia coli for synoptic survey of July 24-29, 1988, and location of municipal wastewater-treatment plants with permitted discharges of 1.0 million gallons per day or more

27. Graph showing densities of Escherichia coli in the Big Blue River, Litule Blue River, and Kansas River subbasins in lower Kansas River Basin, Kansas and Nebraska, for synoptic survey of July 24-29, 1988.

28. Graph showing concentrations of dissolved lithium in water at fixed stations in lower Kansas

River Basin, Kansas and Nebraska, May 1987-April 1990

29. Map showing concentrations of atrazine in surface water during low flow, July 1988, and estimated atrazine use by county, 1989

30-34. Graphs showing:

30. Distribution of concentrations of five major herbicides in surface water in lower Kansas River Basin, Kansas and Ncbraska, during low flow, July 1988

31. Scasonal variations of atrazine and metolachlor concentrations in surface water in lower Kansas River Basin, Kansas and Ncbraska, during low flow, July 1988 to May-June 1989 .....

32. Distribution of five major herbicides in surface water collected over the expected range of streamflows at 12 fixed stations in lower Kansas River Basin, Kansas and Nebraska, March 1989-Fcbruary 1990

33. Concentrations of atrazine in water in unregulated and regulated reaches of Delaware and Big Blue Rivers, March 1989-February 1990

34. Daily mean streamflow and concentrations of atrazine in water from West Fork Big Blue River near Dorchester, Nebraska, May 10-June 21, 1987.

35. Map showing mean of monthly mean concentrations of atrazine at 12 fixed stations, March 1989February 1990

36. Map showing concentrations of organochlorine insecticides in fish tissue, 1987-89, relative to National Academy of Science and National Academy of Engineering guidelines and U.S. Food and Drug Administration chlordane action level.

\section{TABLES}

1. Summary of land-use change within lower Kansas River Basin, by county, due to implementation of the Conservation Reserve Program, 1986-90

2. Selected characteristics of streamflow at selected sampling stations in lower Kansas River Basin, Kansas and Nebraska

3. Selected inorganic constituents and properties, their association with principal environmental effects, and their association with the water-quality issues addressed by the National Water-Quality Assessment Program.

4. Sampling stations, listed in downstream order, May 1987-April 1990.

5. Statistical summary of data for dissolved solids and major ions in water from fixed stations in lower Kansas River Basin, Kansas and Nebraska, May 1987-April 1990.

6. Transport rates of dissolved solids, sodium, and chloride at selected fixed stations in lower Kansas River Basin, Kansas and Nebraska, May 1987-April 1990

7. Trend-test results for dissolved solids and selected major ions in water from selected fixed stations in lower Kansas River Basin, Kansas and Nebraska 


\section{TABLES-Continued}

8. Statistical summary of data for suspended-sediment concentration and particle size in lower Kansas River Basin, Kansas and Nebraska, May 1987-April 1990

9. Transport rate and yield of suspended sediment at fixed stations in lower Kansas River Basin, Kansas and Nebraska, May 1987-April 1990

10. Annual transport rate of suspended sediment at Kansas River stations for selected years of low, medium, and high streamflows, $1978-90$ water years

11. Trend-test results for flow-adjusted suspended-sediment concentrations at selected fixed stations...... in lower Kansas River Basin, Kansas and Nebraska

12. Statistical summary of data for nutrients in water from fixed stations in lower Kansas River Basin, Kansas and Nebraska, May 1987-April 1990

13. Transport rates and yields of nutrients at fixed stations in lower Kansas River Basin, Kansas and Nebraska, May 1987-April 1990

14. Trend-test results for nitrogen and phosphorus in water from selected fixed stations in lower Kansas River Basin, Kansas and Nebraska

15. Statistical summary of concentrations of selected dissolved metals and trace elements in water from fixed stations in lower Kansas River Basin, Kansas and Nebraska, May 1987-April 1990.........

16. Trend-test results for dissolved iron and manganese in water from selected fixed stations in lower Kansas River Basin, Kansas and Nebraska.

17. Statistical summary of concentrations of trace elements in suspended sediment from selected fixed stations in lower Kansas River Basin, Kansas and Nebraska, May 1987-April 1990

18. Median and 90th-percentile concentrations of selected elements in streambed sediment of firstand second-order streams in lower Kansas River Basin; Kansas and Nebraska, SeptemberOctober 1987, geometric mean concentrations in soils of the western United States, and abundance in selected rock types

19. Summary of data for selected trace elements in composite samples of whole fish from 14 sampling stations, 1979-86, and from 12 sampling stations, 1987-90, in lower Kansas River Basin, Kansas and Nebraska

20. Estimated quantities of pesticides used in the lower Kansas River Basin, Kansas and Nebraska, 1989

21. Statistical summary of concentrations of herbicides and insecticides in water from streams in lower Kansas River Basin, Kansas and Nebraska, May 1987-February 1990.

22. Summary of detections of organochlorine insecticides in streambed sediment in lower Kansas River Basin, Kansas and Nebraska, during extended low flow, April 1989

23. Statistical summary of data on $\mathrm{pH}$, alkalinity, and organic carbon in water from fixed stations in lower Kansas River Basin, Kansas and Nebraska, May 1987-April 1990

24. Trend-test results for $\mathrm{pH}$ of water from selected fixed stations in lower Kansas River Basin, Kansas and Nebraska 


\begin{tabular}{|c|c|c|}
\hline Multiply & By & To obtaln \\
\hline $\begin{array}{r}\text { inch (in.) } \\
\text { inch per year (in/yr) } \\
\text { foot (ft) } \\
\text { mile (mi) } \\
\text { acre } \\
\text { square mile }\left(\mathrm{mi}^{2}\right) \\
\text { gallon per day }(\mathrm{gal} / \mathrm{d}) \\
\text { million gallons per day }(\mathrm{Mgal} / \mathrm{d}) \\
\text { cubic foot per second (ft } 3 / \mathrm{s}) \\
\text { acre-foot (acre-ft) } \\
\text { acre-foot per year (acre-ft } / \mathrm{yr}) \\
\text { pound }(\mathrm{lb}) \\
\text { ton }(\mathrm{short}) \\
\text { pound per square mile }\left(\mathrm{lb} / \mathrm{mi}^{2}\right) \\
\text { ton per year }\left(\text { ton } / \mathrm{yr}^{2}\right) \\
\left.\text { ton per square mile (ton } / \mathrm{mi}^{2}\right) \\
\text { degree Fahrenheit }\left({ }^{\circ} \mathrm{F}\right)\end{array}$ & $\begin{array}{l}2.54 \\
2.54 \\
0.3048 \\
1.609 \\
4,047 \\
2.590 \\
0.06309 \\
0.06309 \\
0.02832 \\
1,233 \\
1,233 \\
0.4536 \\
0.9072 \\
0.1751 \\
0.9072 \\
0.3503 \\
(1)\end{array}$ & $\begin{array}{l}\text { centimeter } \\
\text { centimeter per year } \\
\text { meter } \\
\text { kilometer } \\
\text { square meter } \\
\text { square kilometer } \\
\text { liter per day } \\
\text { million liters per day } \\
\text { cubic meter per second } \\
\text { cubic meter } \\
\text { cubic meter per year } \\
\text { kilogram } \\
\text { megagram } \\
\text { kilogram per square kilometer } \\
\text { megagram per year } \\
\text { megagram per square kilometer } \\
\text { degree Celsius }\left({ }^{\circ} \mathrm{C}\right)\end{array}$ \\
\hline
\end{tabular}

\section{Additional Abbreviations}

$\begin{array}{ll}\mathrm{mg} / \mathrm{L} & =\text { milligram per liter } \\ \mu \mathrm{g} / \mathrm{L} & =\text { microgram per liter } \\ \mathrm{col} / 100 \mathrm{~mL} & =\text { colonies per } 100 \text { milliliters } \\ \mu \mathrm{g} / \mathrm{g} & =\text { microgram per gram } \\ \mu \mathrm{g} / \mathrm{kg} & =\text { microgram per kilogram } \\ \mathrm{pC} \mathrm{i} / \mathrm{L} & =\text { picocurie per liter } \\ \mathrm{millirem} / \mathrm{yr} & =\text { millirem per year }\end{array}$

The use of company or trade names in this report is for information or identification purposes only and does not constitute endorsement by the U.S. Geological Survey. 



\title{
Surface-Water-Quality Assessment of the Lower Kansas River Basin, Kansas And Nebraska: Results of Investigations, 1987-90
}

\author{
Edited by J.O. Helgesen
}

Abstract

Surface-water-quality conditions and trends were assessed in the lower Kansas River Basin, which drains about 15,300 square miles of mainly agricultural land in southeast Nebraska and northeast Kansas. On the basis of established water-quality criteria, most streams in the basin were suitable for uses such as public-water supply, irrigation, and maintenance of aquatic life. However, most concerns identified from a previous analysis of available data through 1986 are substantiated by analysis of data for May 1987 through April 1990. Less-than-normal precipitation and runoff during 1987-90 affected surface-water quality and are important factors in the interpretation of results.

Dissolved-solids concentrations in the main stem Kansas River during May 1987 through April 1990 commonly exceeded 500 milligrams per liter, which may be of concern for public-water supplies and for the irrigation of sensitive crops. Large concentrations of chloride in the Kansas River are derived from ground water discharging in the Smoky Hill River Basin west of the study unit. Trends of increasing concentrations of some dissolved major ions were statistically significant in the northwestern part of the study unit, which could reflect substantial increases in irrigated acreage.

The largest concentrations of suspended sediment in streams during May 1987 through April 1990 were associated with high-density cropland in areas of little local relief and medium-density irrigated cropland in more dissected areas. The smallest concentrations were measured downstream from large reservoirs and in streams draining areas having little or no row-crop cultivation. Mean annual suspended-sediment transport rates in the main stem Kansas River increased substantially in the downstream direction. No conclusions could be reached concerning the relations of suspended-sediment transport, yields, or trends to natural and human factors.

The largest sources of nitrogen and phosphorus in the study unit were fertilizer and livestock. Nitrate-nitrogen concentrations in stream-water samples did not exceed 10 milligrams per liter; relatively large concentrations in the northwestern part of the study unit were associated with fertilizer application. Concentrations of total phosphorus generally were largest in the northwestern part of the study unit, which probably relates to the prevalence of cultivated land, fertilizer application, and livestock wastes.

Deficiencies in dissolved-oxygen concentrations in streams occurred locally, as a result of discharges from wastewater-treatment plants, algal respiration, and inadequate reaeration associated with small streamflow. Large densities of a fecal-indicator bacterium, Escherichia coli, were associated with discharges from municipal wastewater-treatment plants and, especially in the northwestern part of the study unit, with transport of fecal material from domestic livestock.

The largest concentrations of the herbicide atrazine generally were measured where the largest quantities of atrazine were applied to the land. Large atrazine concentrations, 10 to 20 micrograms per liter, were measured most 
frequently in unregulated principal streams during May and June. Downstream of reservoirs, the seasonal variability of atrazine concentrations was decreased compared to that of inflowing streams.

\section{INTRODUCTION}

\section{Background}

Beginning in 1986, the Congress appropriated funds for the U.S. Geological Survey to test and refine concepts for a National Water-Quality Assessment (NAWQA) Program (Hirsch and others, 1988). The NAWQA Program is designed to address a variety of water-quality issues that include chemical contamination, acidification, eutrophication, salinity, sedimentation, and sanitary quality. The long-term goals of the program are to:

1. Provide a nationally consistent description of current water-quality conditions for a large part of the Nation's water resources;

2. Define long-term trends (or lack of trends) in water quality; and

3. Identify, describe, and explain, as possible, the major factors that affect observed waterquality conditions and trends.

This information will provide water managers, policy makers, and the public with an improved scientific basis for evaluating the effectiveness of water-quality-management programs and for projecting the likely effects of contemplated changes in land- and water-management practices.

The NAWQA Program is organized into study units on the basis of known hydrologic systems (Leahy and others, 1990), either major river basins or large parts of aquifers or aquifer systems. The pilot phase of the assessment program covers seven study units (see cover) representing a diversity of hydrologic environments and water-quality conditions. The subject of this report is the lower Kansas River Basin, which consists of the Kansas River and its drainage area downstream from the confluence of the Republican and Smoky Hill Rivers to the confluence with the Missouri River (fig. 1). A description of the study, which focuses primarily on surface water, is given by Stamer and others (1987).

\section{Purpose and Scope}

This report presents the results of the waterquality assessment of the lower Kansas River Basin in Kansas and Nebraska, conducted during 1987-90. Specifically, the report describes water-quality conditions, long-term trends, and relations of water quality to natural and human factors.

The scope of the report includes the analysis of data to assess current surface-water-quality conditions and long-term trends, and to identify the major factors that affect them. The report is based on data collected primarily by the U.S. Geological Survey from May 1987 through April 1990, and on earlier data collected by several agencies and presented by Jordan and Stamer (1991).

\section{Acknowledgments}

The authors and editor thank the many local, State, and Federal agencies for their cooperation in providing information and data used to prepare this report. Specifically, assistance from the Kansas Department of Health and Environment, the Nebraska Department of Environmental Quality, and U.S. Environmental Protection Agency's Region VII, is appreciated. Special thanks are given to the members of the lower Kansas River Basin Liaison Committee (Stamer and others, 1987) and the National Coordinating Work Group (Hirsch and others, 1988), who provided useful guidance for conducting this study.

\section{DESCRIPTION OF LOWER KANSAS RIVER BASIN}

The lower Kansas River Basin (Dugan and others, 1991) includes about $15,300 \mathrm{mi}^{2}$ and coincides with the area defined by the U.S. Water Resources Council as hydrologic subregion 1027 (Seaber and others, 1984). Although $7.5 \mathrm{mi}^{2}$ of the subregion lies within Missouri, drainage from this small area near the confluence of the Kansas and Missouri Rivers does not affect the quality of water 


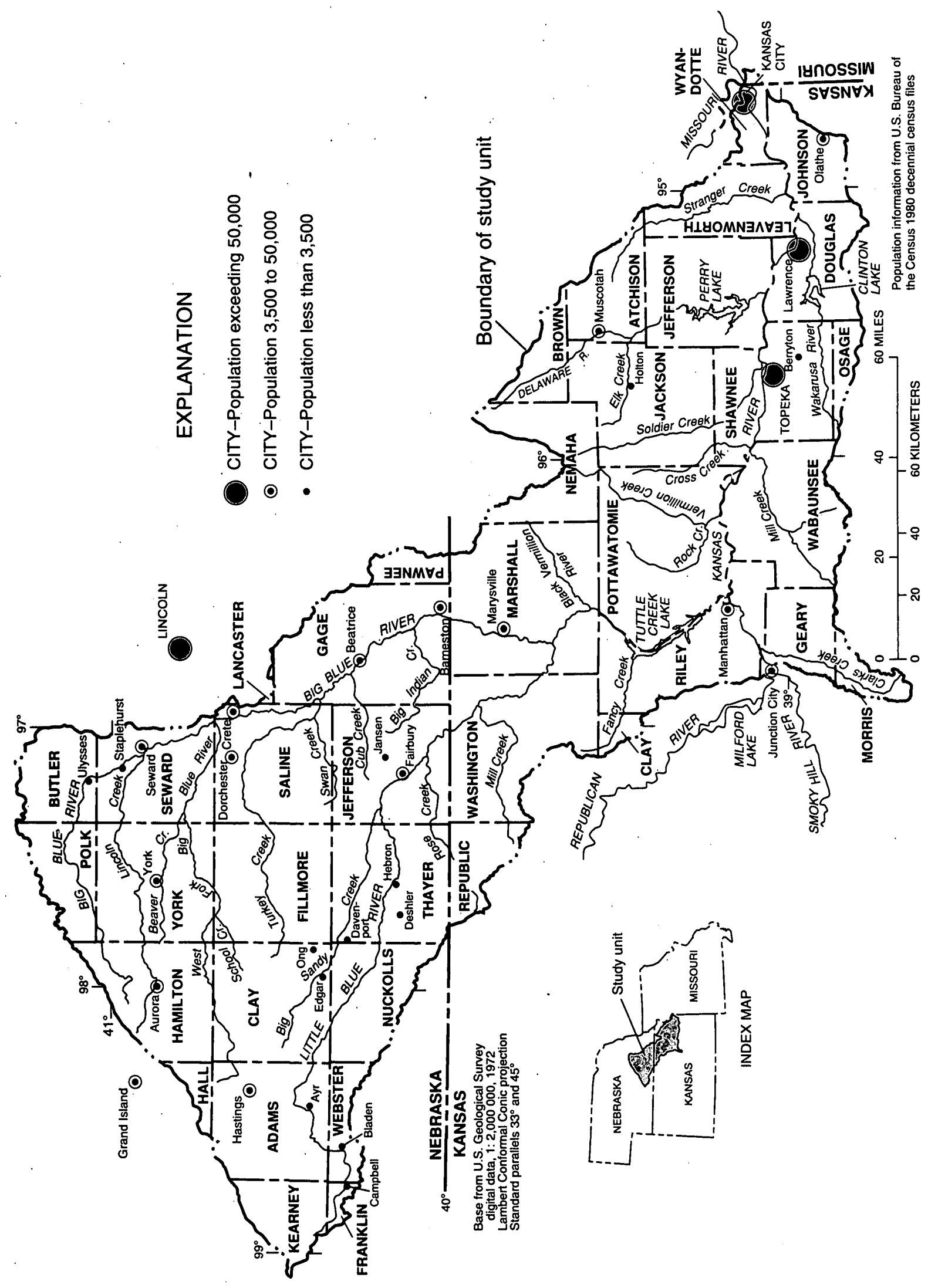

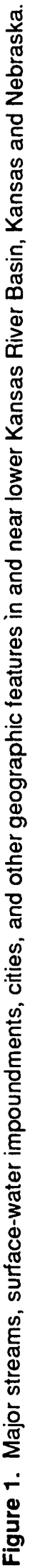


used within the study unit and is not included in the study. The study unit includes the Big Blue River subbasin in Nebraska and Kansas, as well as subbasins of smaller tributaries to the 170-mi reach of the Kansas River from Junction City to Kansas City, Kans. (fig. 1). The Kansas River is formed by the confluence of the Republican and Smoky Hill Rivers at Junction City, Kans. Three large reservoirs (Clinton, Perry, and Tuttle Creek Lakes) lie within the Kansas part of the study unit (fig. 1). Population of the study unit was about 823,000 in 1990 (U.S. Bureau of the Census, 1991a, 1991b).

\section{Physical Features}

Landforms in the lower Kansas River Basin are characterized by the four physiographic sections shown in figure 2 (Fenneman, 1946). Smooth plains with little local relief dominate the High Plains Section; fluvial and eolian deposits of sand, gravel, silt, and clay underlie this part of the study unit. The Plains Border Section is more dissected than the High Plains and is underlain by shale, sandstone, and limestone, and minor fluvial and eolian deposits. The Dissected Till Plains Section is characterized by deposits of glacial till composed of silt, clay, sand, gravel, and boulders that overlie bedrock of primarily shale and limestone, with some sandstone. The Osage Plains Section is south of the limit of glaciation and is underlain primarily by shale and limestone, with some sandstone. Drainage patterns in the Osage Plains are well defined although dissection of the land is less than in the Dissected Till Plains.

The surficial geology of the lower Kansas River Basin is shown in figure 3. The northwestern part of the study unit consists primarily of Quaternary loess deposits, whereas the northeastern part consists primarily of Quatemary glacial drift. A small area in the west-central part of the study unit is composed of Upper and Lower Cretaceous sandstone and limestone, and the southern part consists of Permian and Pennsylvanian shale and limestone. Quaternary alluvium fills the major river valleys throughout the study unit.

The predominant soil order of the lower Kansas River Basin (fig. 4) is the Mollisol. Mollisols have a surface horizon that is thick, dark-colored, high in base saturation, and granular in structure (Dugan, 1984). Entisols, Inceptisols, and Alfisols also are present in the study unit. Entisols, which are soils with no diagnostic horizon, occur on sandy parent material (psamments) in the western part of the study unit and on soil formed from alluvial deposits (fluvents). Inceptisols are considered to be immature soils resembling their parent material (Buol and others, 1980), and Alfisols are characterized by an argillic or clay-rich horizon.

\section{Land Use}

Land use in the lower Kansas River Basin (fig. 5) is about 85 percent agricultural and is typical of the Midwestem United States agricultural region. Corn, sorghum, wheat, and soybeans are the principal crops. The most intensively cultivated and irrigated land is located in the northwestern part of the study unit. In a 1987 inventory of land use (U.S. Soil Conservation Service, written commun., 1990, data tables), estimates for drainage areas in the northwestern part of the basin indicate that more than 55 percent of the cropland is irrigated. Estimates from the same inventory indicate that, although only about 3 percent of the study unit is covered by woodlands, nearly 10 percent of the southeastern part is wooded. Nearly 10 percent of the study unit consists of urban or industrial area; the principal urban and industrial developments include part of the Kansas City metropolitan area, Topeka, and Lawrence, Kans. Pasture and rangeland together cover about 25 percent of the study unit, mostly in the southwestern part.

Beginning in 1986, cropland that was considered highly erodible could be removed from production and placed into the U.S. Department of Agriculture's Conservation Reserve Program (CRP). About 4.2 percent of the cropland in the study unit was placed into the CRP during 1986-90 (table 1). A larger percentage of land was removed from production in Kansas than in Nebraska (table 1, fig. 6), which probably reflects greater topographic relief, precipitation, runoff, and erodibility of soils in the Kansas part of the basin. 


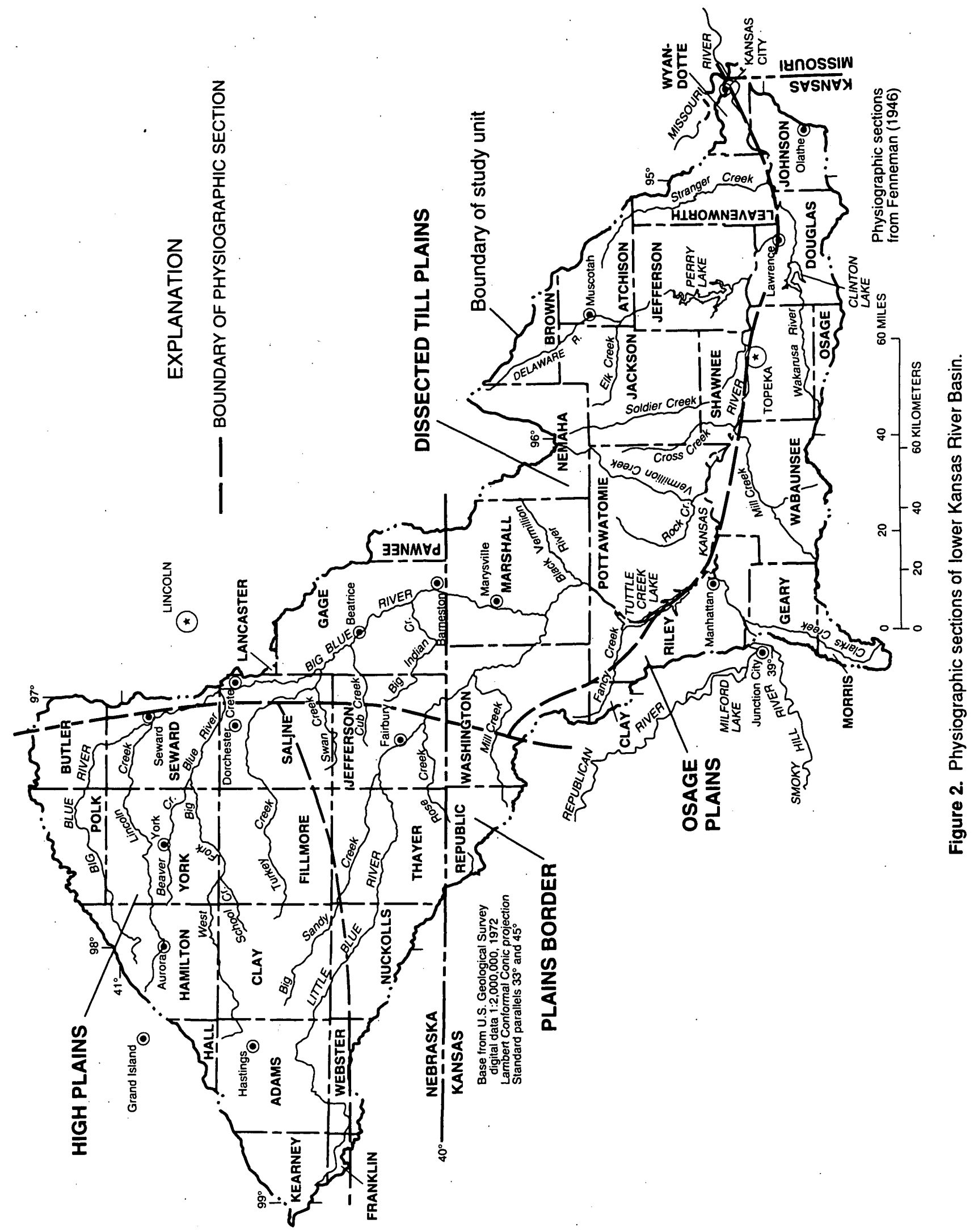




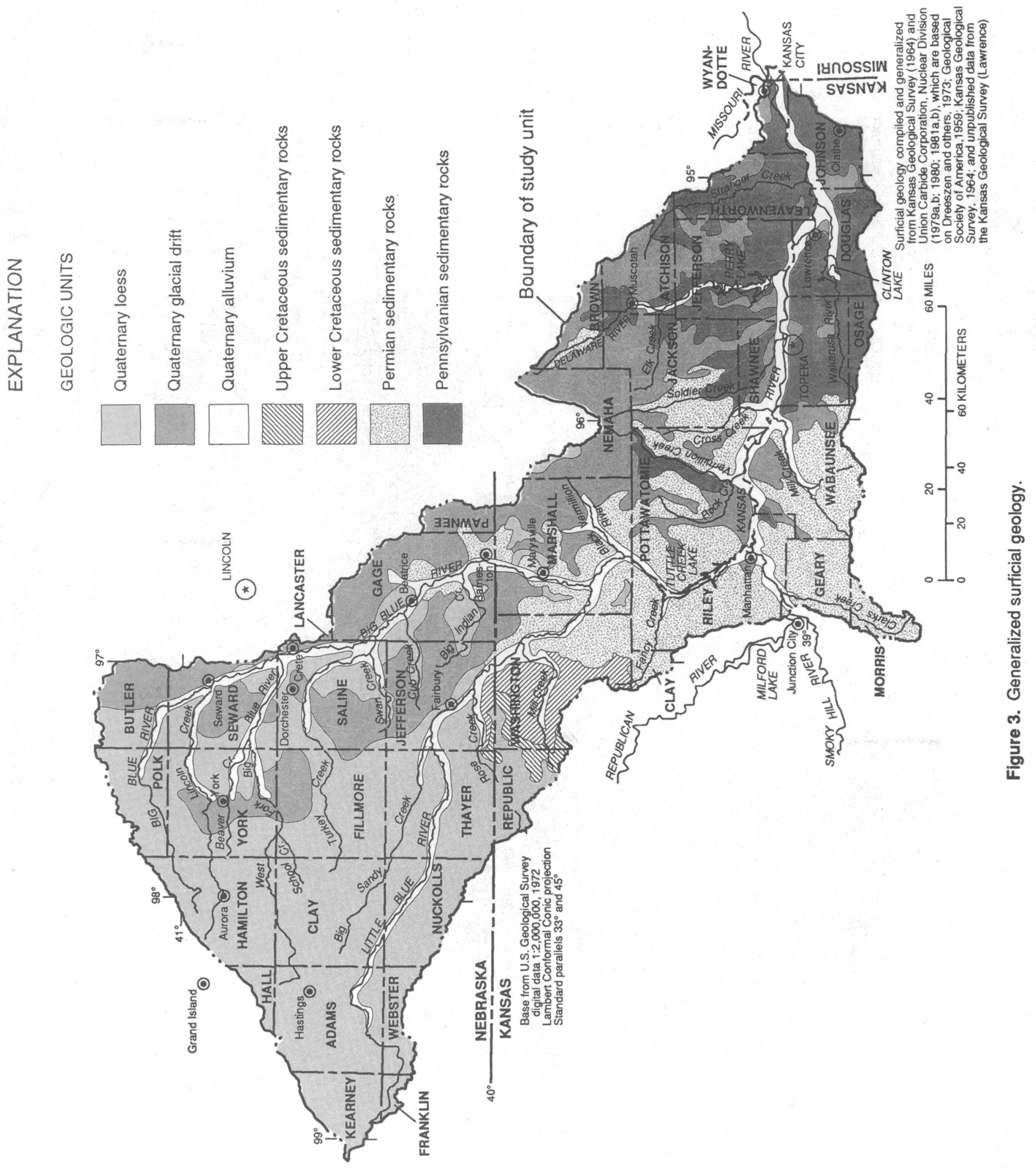

6 Surface-Water-Quality Assessment of the Lower Kansas River Basin, Kansas and Nebraska: Results of Investigations, 

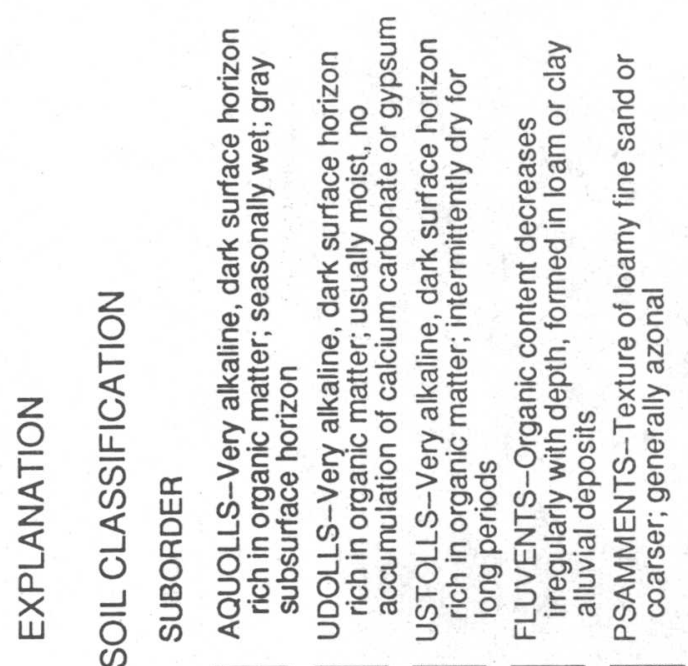

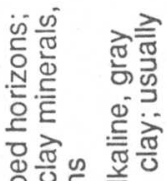

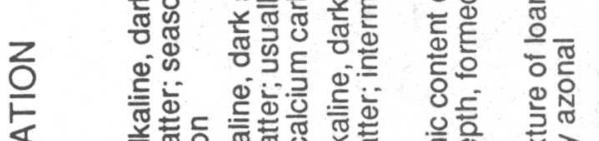

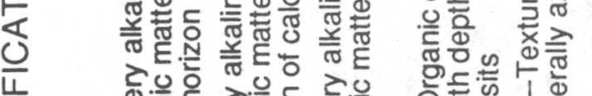

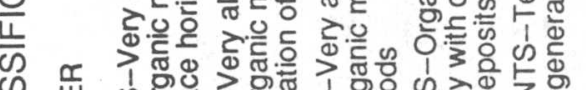

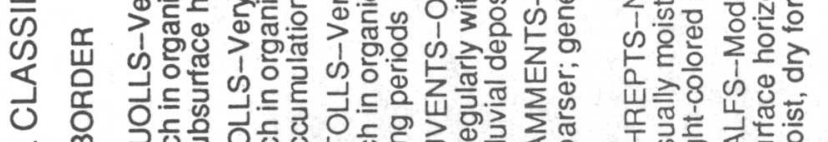

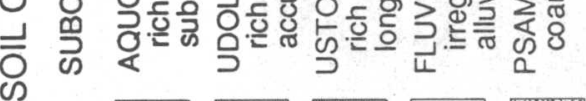

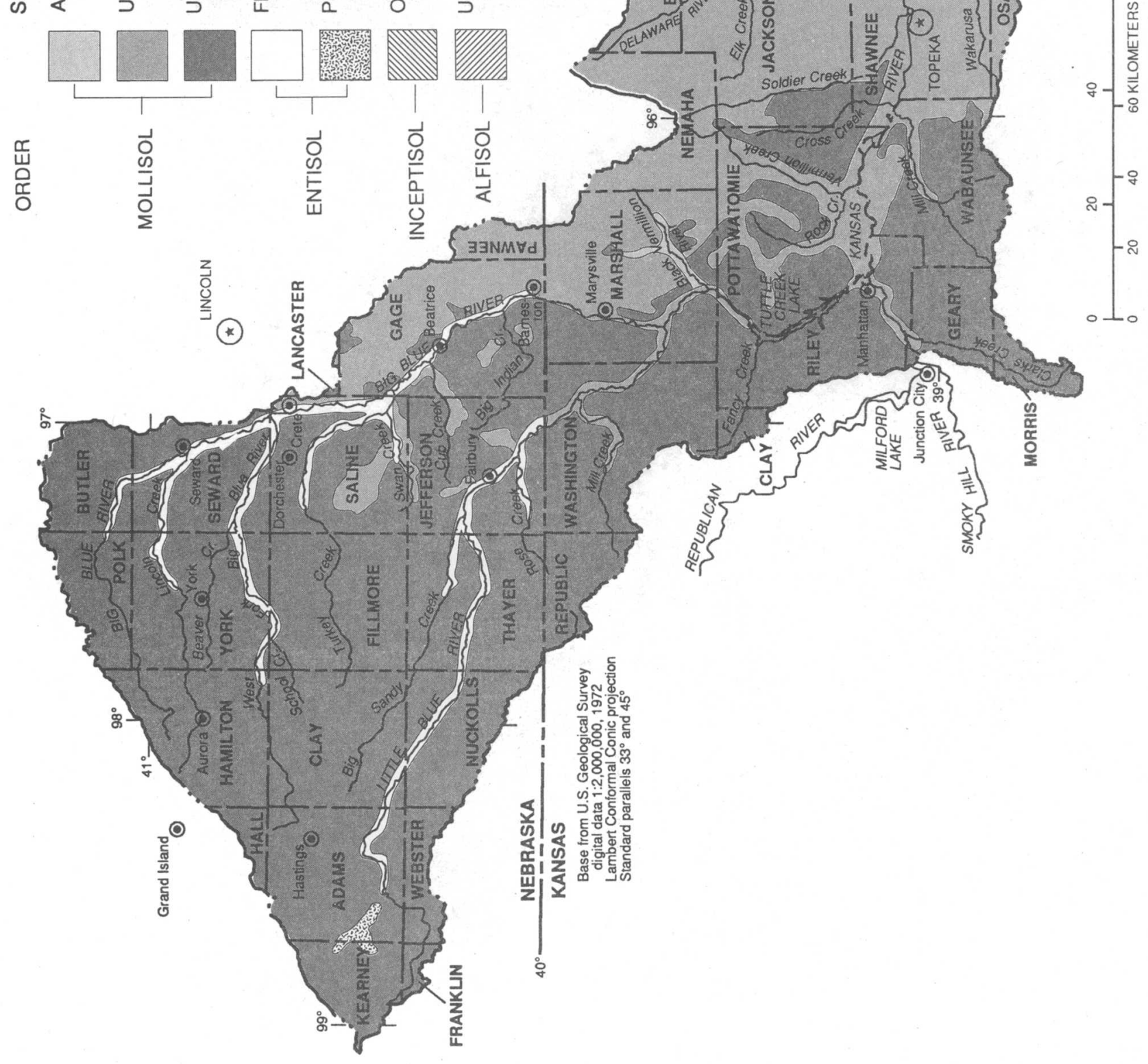

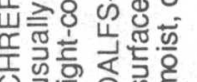

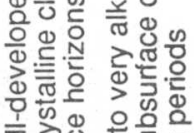

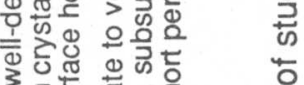

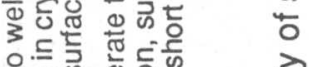
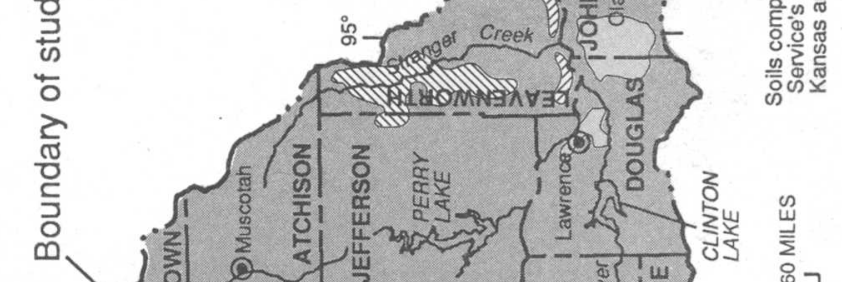

岂 


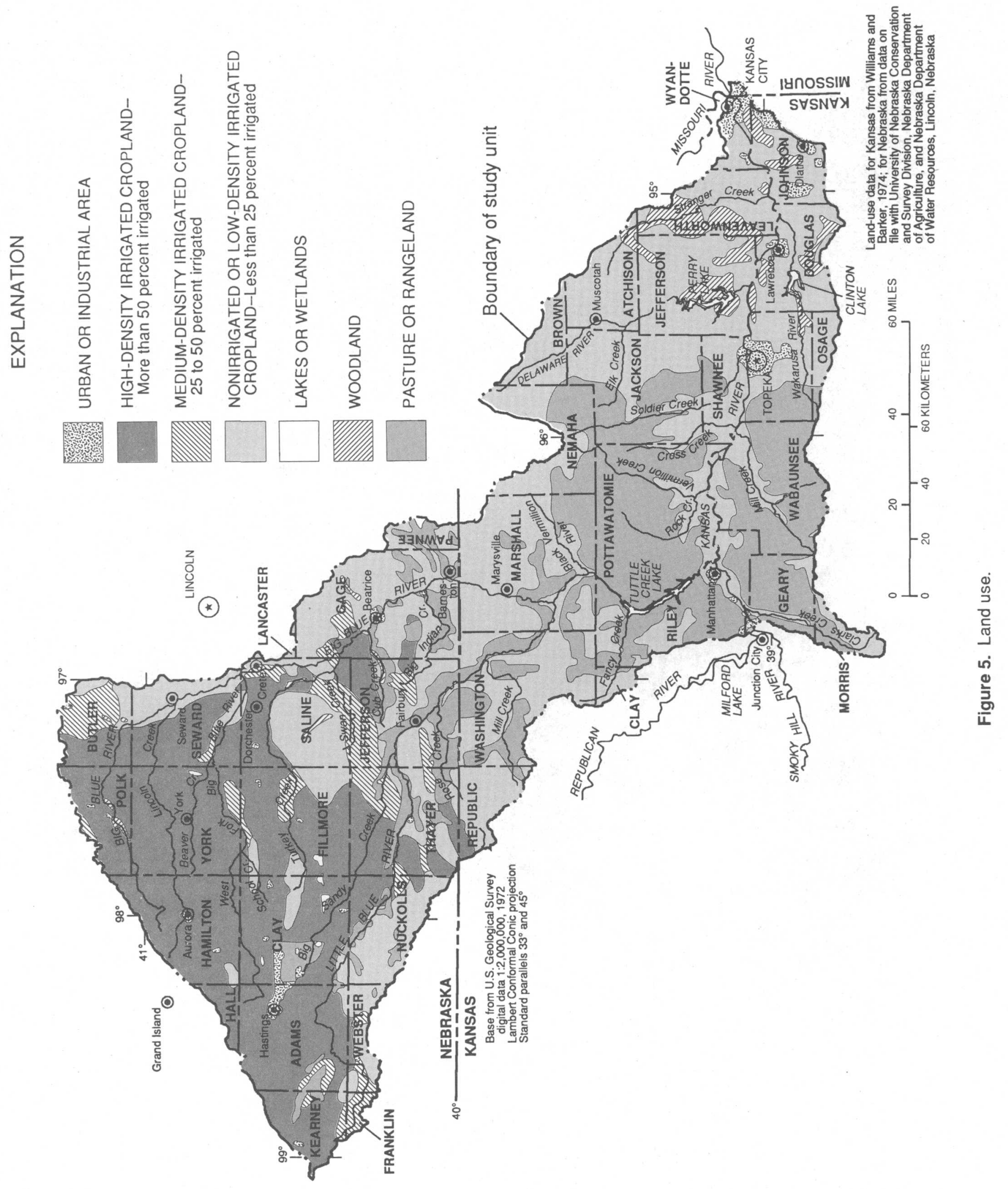

8 Surface-Water-Quality Assessment of the Lower Kansas River Basin, Kansas and Nebraska: Results of Investigations, 1987-90 
Table 1. Summary of land-use change within lower Kansas River Basin, by county, due to implementation of the Conservation Reserve Program (CRP), 1986-90

[Calculated from data provided by the U.S. Agricultural Stabilization and Conservation Service, Lincoln, Nebr., U.S. Soil Conservation Service, Salina, Kans., and U.S. Bureau of Census (1989a, 1989b)]

\begin{tabular}{|c|c|c|c|}
\hline County & $\begin{array}{l}\text { Area of } \\
\text { cropland in } \\
1987 \text {, In acres }\end{array}$ & $\begin{array}{l}\text { Cropland } \\
\text { removed from } \\
\text { productlon due } \\
\text { to CRP, as a } \\
\text { percentage of } \\
\text { total cropland }\end{array}$ & $\begin{array}{l}\text { Cropland } \\
\text { removed from } \\
\text { productlon due } \\
\text { to CRP, as a } \\
\text { percentage of } \\
\text { total land area }\end{array}$ \\
\hline \multicolumn{4}{|c|}{ Kansas } \\
\hline Atchison & 119,353 & 3.0 & 2.0 \\
\hline Brown & 80,771 & 4.2 & 3.1 \\
\hline Clay & 23,684 & 8.0 & 5.6 \\
\hline Douglas & 124,585 & 4.2 & 2.2 \\
\hline Geary & 43,278 & 2.5 & 0.8 \\
\hline Jackson & 208,974 & 10.4 & 5.2 \\
\hline Jefferson & 177,967 & 8.8 & 4.6 \\
\hline Johnson & 53,744 & 2.8 & 1.0 \\
\hline Leavenworth & 111,217 & 4.3 & 2.1 \\
\hline Marshall & 394,721 & 5.1 & 3.7 \\
\hline Morris & 31,283 & 4.2 & 1.9 \\
\hline Nemaha & 174,632 & 9.9 & 7.1 \\
\hline Osage & 28,913 & 8.2 & 4.0 \\
\hline Pottawatomie & 188,003 & 7.8 & 2.8 \\
\hline Republic & 95,426 & 4.0 & 2.9 \\
\hline Riley & 118,801 & 2.7 & 1.0 \\
\hline Shawnee & 149,707 & 5.3 & 2.3 \\
\hline Wabaunsee & 112,363 & 10.4 & 3.1 \\
\hline Washington & 291,320 & 7.2 & 4.7 \\
\hline Wyandotte & 11.102 & 1 & $\leq 1$ \\
\hline Kansas portion & $2,539,844$ & 6.4 & 3.2 \\
\hline \multicolumn{4}{|c|}{ Nebraska } \\
\hline Adams & 302,034 & 1.2 & 1.0 \\
\hline Butler & 152,121 & 3.4 & 2.8 \\
\hline Clay & 302,827 & .6 & .5 \\
\hline Fillmore & 331,629 & .4 & .3 \\
\hline Franklin & 14,069 & 3.8 & 2.1 \\
\hline Gage & 387,034 & 8.6 & 6.8 \\
\hline Hall & 31,157 & .6 & .4 \\
\hline Hamilton & 285,355 & .3 & .2 \\
\hline
\end{tabular}


Table 1. Summary of land-use change within lower Kansas River Basin, by county, due to implementation of the Conservation Reserve Program (CRP), 1986-90-Continued

\begin{tabular}{|c|c|c|c|}
\hline County & $\begin{array}{c}\text { Area of } \\
\text { cropland in } \\
1987 \text {, in acres }\end{array}$ & $\begin{array}{l}\text { Cropland } \\
\text { removed from } \\
\text { production due } \\
\text { to CRP, as a } \\
\text { percentage of } \\
\text { total cropland }\end{array}$ & $\begin{array}{l}\text { Cropland } \\
\text { removed from } \\
\text { production due } \\
\text { to CRP, as a } \\
\text { percentage of } \\
\text { total land area }\end{array}$ \\
\hline \multicolumn{4}{|c|}{ Nebraska-Continued } \\
\hline Jefferson & 257,564 & 5.4 & 3.8 \\
\hline Kearney & 126,287 & .7 & .6 \\
\hline Lancaster & 4,054 & 7.0 & 4.9 \\
\hline Nuckolls & 163,096 & 2.1 & 1.4 \\
\hline Pawnee & 37,089 & 23.3 & 13.6 \\
\hline Polk & 143,662 & .2 & .2 \\
\hline Saline & 289,179 & 3.3 & 2.6 \\
\hline Seward & 238,516 & 3.1 & 2.5 \\
\hline Thayer & 301,572 & 2.3 & 1.9 \\
\hline Webster & 47,479 & 7.9 & 4.2 \\
\hline York & 319.700 & 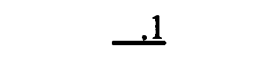 & .1 \\
\hline Nebraska portion & $3,734,424$ & 2.7 & 2.2 \\
\hline Entire basin & $6,274,268$ & 4.2 & 2.7 \\
\hline
\end{tabular}

\section{Cllmate}

Climate in the lower Kansas River Basin is characterized by hot, humid summers and cold winters, with no particular dry season. July normally is the warmest month in the basin with a mean temperature of about $25^{\circ} \mathrm{C}$, and January normally is the coldest month with a mean temperature of about $-4^{\circ} \mathrm{C}$. (Climatic data are from the National Oceanic and Atmospheric Administration, 1951-80.)

Precipitation in the study unit is the most significant climatic factor for agriculture and surface-water availability because of both temporal and spatial variability. The 1951-80 mean annual precipitation ranged from about 24 in. in the northwestern part of the study unit to about 36 in. in the southeast. During the May 1987-April 1990 study period, annual precipitation in most of the basin was less than the long-term mean; departures from the 1951-80 annual mean ranged from positive 2 in. in the northwestern part of the basin to negative 10 in. in the southeastern part (fig. 7). Extreme variability in precipitation patterns contributes to increased potential for short-term and long-term drought and for periodic flooding within the basin.

Potential evapotranspiration, an indicator of consumptive water use, ranges from about $48 \mathrm{in} / \mathrm{yr}$ in the western part of the basin to about $42 \mathrm{in} / \mathrm{yr}$ in the northern part, based on the Jensen-Haise technique (Dugan and Peckenpaugh, 1985). During the growing season (April through September), potential evapotranspiration normally exceeds precipitation, and irrigation is a common practice where water supplies are plentiful. During the nongrowing season (October through March), evapotranspiration is less than precipitation, which makes that season the most effective time for precipitation to replenish soil moisture and to recharge the ground-water system.

\section{Surface-Water Hydrology}

The Republican and Smoky Hill Rivers, which join to form the Kansas River at Junction City, Kans. (fig. 1) together drain an area of about $45,000 \mathrm{mi}^{2}$. The largest tributary downstream from Junction City is the Big Blue River, which 


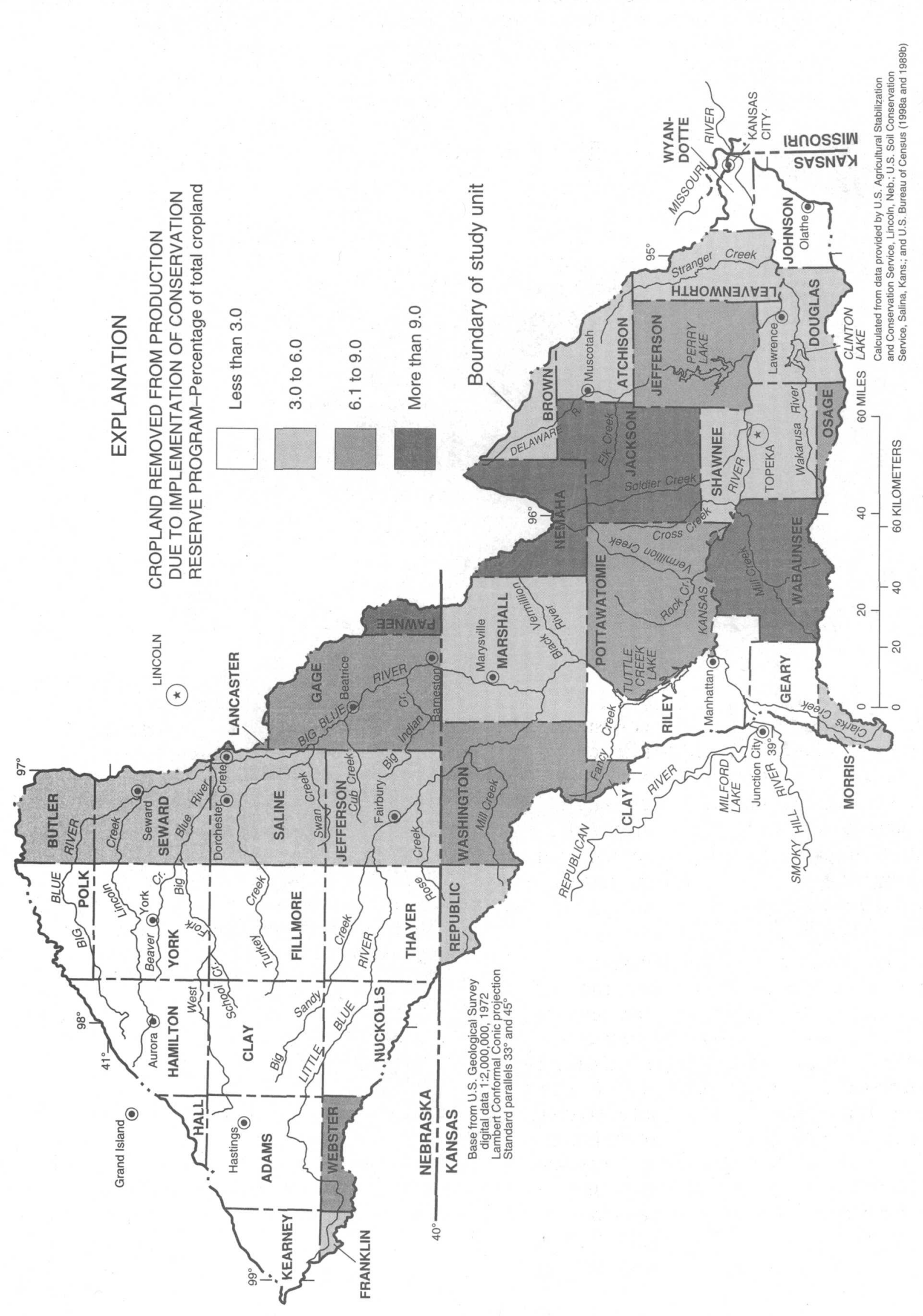

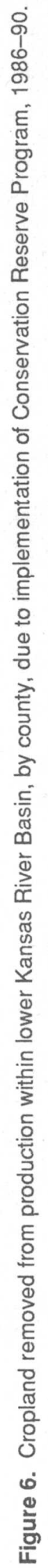




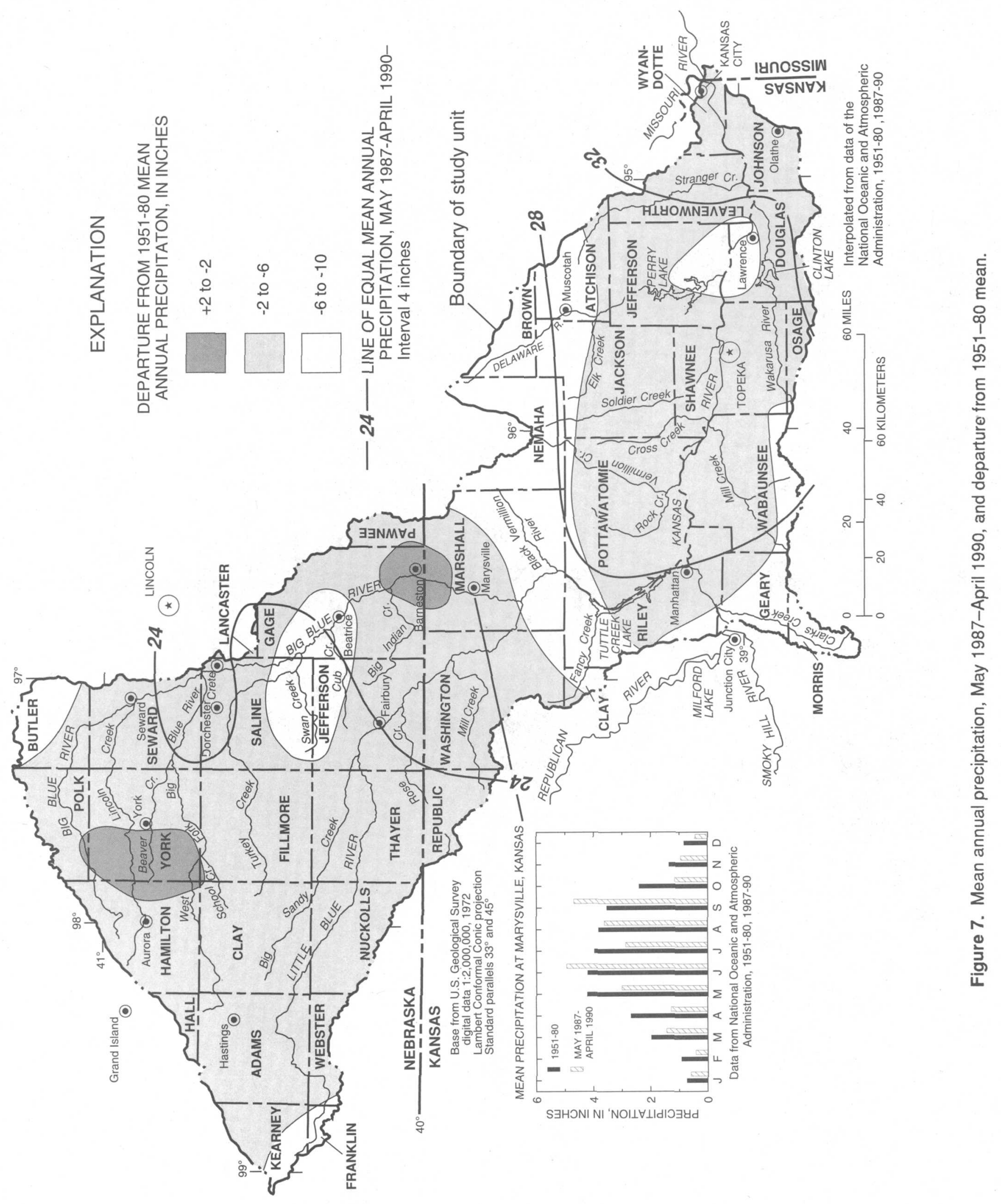

12 Surface-Water-Quality Assessment of the Lower Kansas River Basin, Kansas and Nebraska: Results of Investigations, 
originates in Nebraska. Drainage to the Kansas River from the south is much smaller than that from the north. Although the basin contains many small surface-water impoundments, three large reservoirs (Tuttle Creek Lake on the Big Blue River, Perry Lake on the Delaware River, and Clinton Lake on the Wakarusa River) provide most of the surface-water storage.

The mean flow rate of the Kansas River at its confluence with the Missouri River during 1971-90 was about $8,200 \mathrm{ft}^{3} / \mathrm{s}$. Approximately 70 percent of that flow was derived from within the study unit, and the remainder was contributed by the Republican and Smoky Hill Rivers. Much of the streamflow in the study unit is regulated by reservoirs.

Runoff in the study unit varies areally in response to precipitation, vegetation, topography, soil, and geology, and seasonally in response to precipitation and evapotranspiration. The 1951-80 mean annual runoff ranged from less than 2 in. in the northwestern part of the study unit to almost $9 \mathrm{in}$. in the southeast. During the study period of May 1987-April 1990, below-normal precipitation resulted in less-than-normal runoff; departures from the 1951-80 annual mean ranged from positive $1 \mathrm{in}$. in the northwestern part of the basin to negative $5 \mathrm{in}$. in the southeastern part (fig. 8). The predominantly negative departures in runoff are reflected in a decrease in streamflows, based on data from selected gaging stations in the study unit (table 2, fig. 9). Mean streamflow rates for 1987-90 ranged from 25 to 78 percent of the mean rates for the longer periods listed in table 2 . Variations in streamflow usually have a substantial effect on surface-water quality and constituent transport (Jordan, 1991c).

Hydraulic connections between the surfacewater and ground-water systems have a substantial effect on streamflow and associated water quality in much of the study unit. In particular, flow in the Big and Little Blue Rivers generally is well sustained during dry weather by ground-water contributions (Ellis, 1981). Considerable interchange of water occurs between the Kansas River and its 1to 4-mi wide alluvial aquifer (Fader, 1974; Wolf and Helgesen, 1992). The exchange of water probably has a substantial effect on quantity and quality of water in both the river and the aquifer. In the Dissected Till Plains and Osage Plains, ground water is less plentiful, and stream-aquifer interaction and associated water-quality effects are more discontinuous.

\section{Water Use}

Water use in the lower Kansas River Basin in 1990 totalled about 2.8 million acre-ft (calculated from data on file with the U.S. Geological Survey, Lawrence, Kans., and Lincoln, Nebr.). Of this total, about 61 percent was from surface-water sources. Surface water was used instream, nonconsumptively, for hydroelectric power generation (almost 1.5 million acre-ft), and offstream for public supply (73,000 acre-ft), thermoelectric power generation (63;000 acre-ft), irrigation $(58,000$ acre- $\mathrm{ft})$, and industrial, commercial, mining, and livestock uses (25,000 acre- $\mathrm{ft}$ ). The largest surface-water withdrawals for offstream use were from the Kansas River, and the water was used mainly within counties adjoining the river.

Irrigation withdrawals accounted for about 1 million acre-ft of the total water used and were predominantly from ground-water sources. Most of the irrigation took place in the High Plains Section of the Nebraska part of the study unit. In the Kansas part of the study unit, most of the ground water used for irrigation was pumped from the alluvial aquifer along the Kansas River.

In the Nebraska part of the study unit, all of the municipal and industrial withdrawals in 1990 were from ground water. In the Kansas part of the study unit, all of the industrial withdrawals were from ground water, but 73 percent of the public-supply withdrawals were from surface water. The location of major municipal and industrial withdrawals (1,000 acre-ft/yr or more), and sources of supply in the study are shown in figure 10 . Thermoelectricpower-generation facilities, mining operations, and fish farms are included with industrial users in this figure.

\section{Wastewater Discharges}

Wastewater that enters a stream at a discrete point is referred to as a point source and, as such, is not necessarily related to the geology, soils, or land use of the drainage area. Fifty-seven municipal or industrial facilities in the study unit are permitted by the U.S. Environmental Protection Agency to 


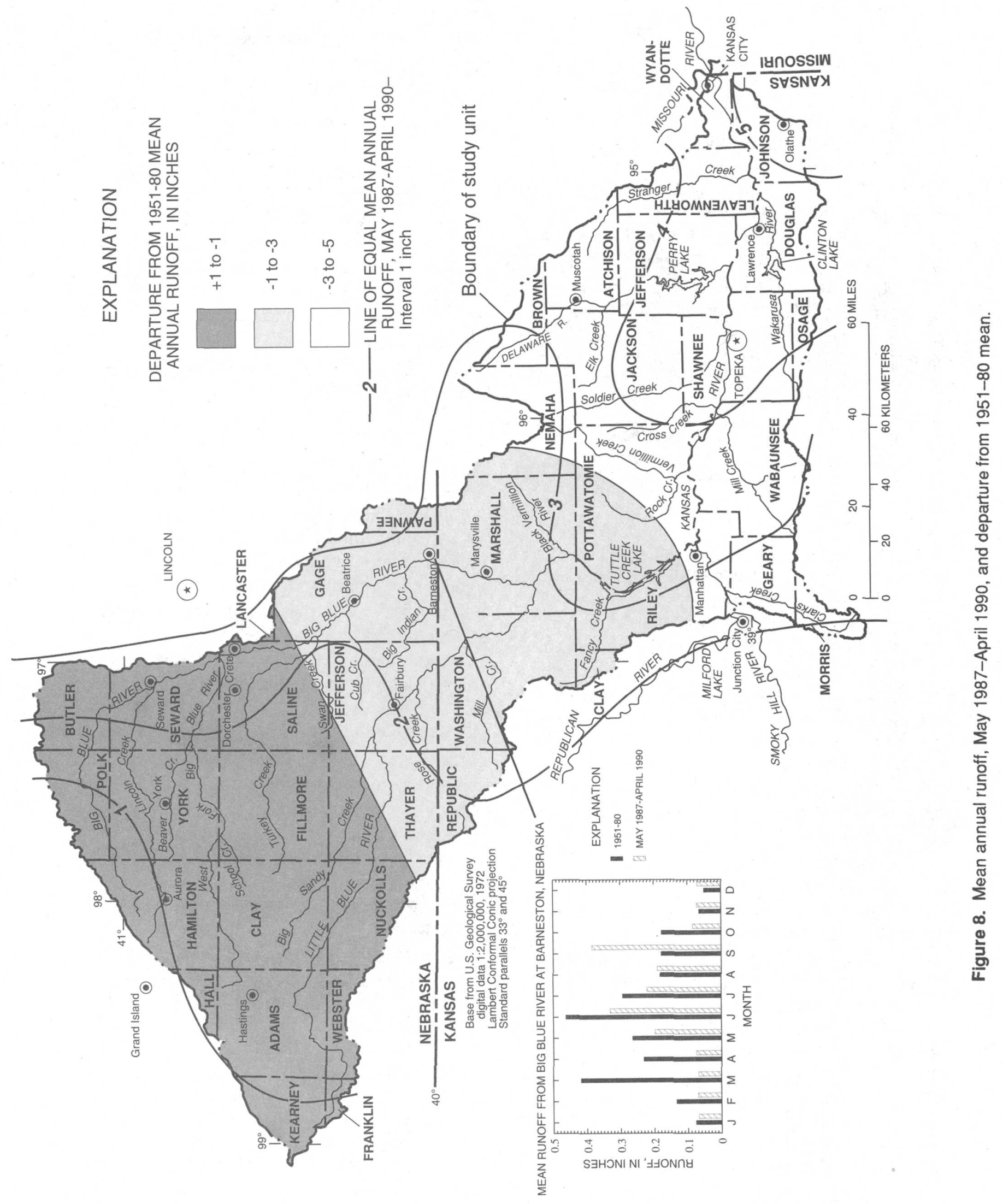

14 Surface-Water-Quality Assessment of the Lower Kansas River Basin, Kansas and Nebraska: Results of Investigations, 


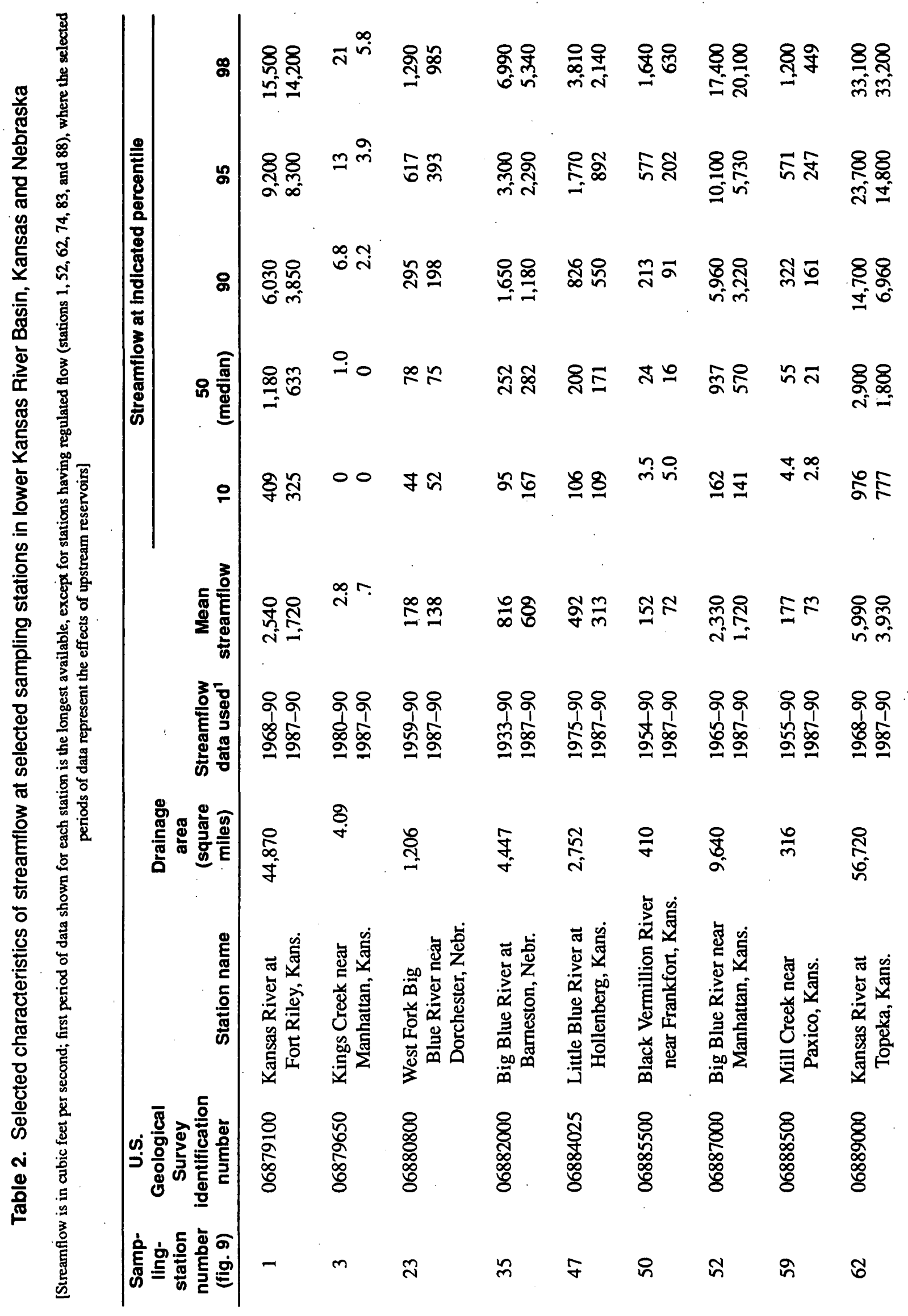




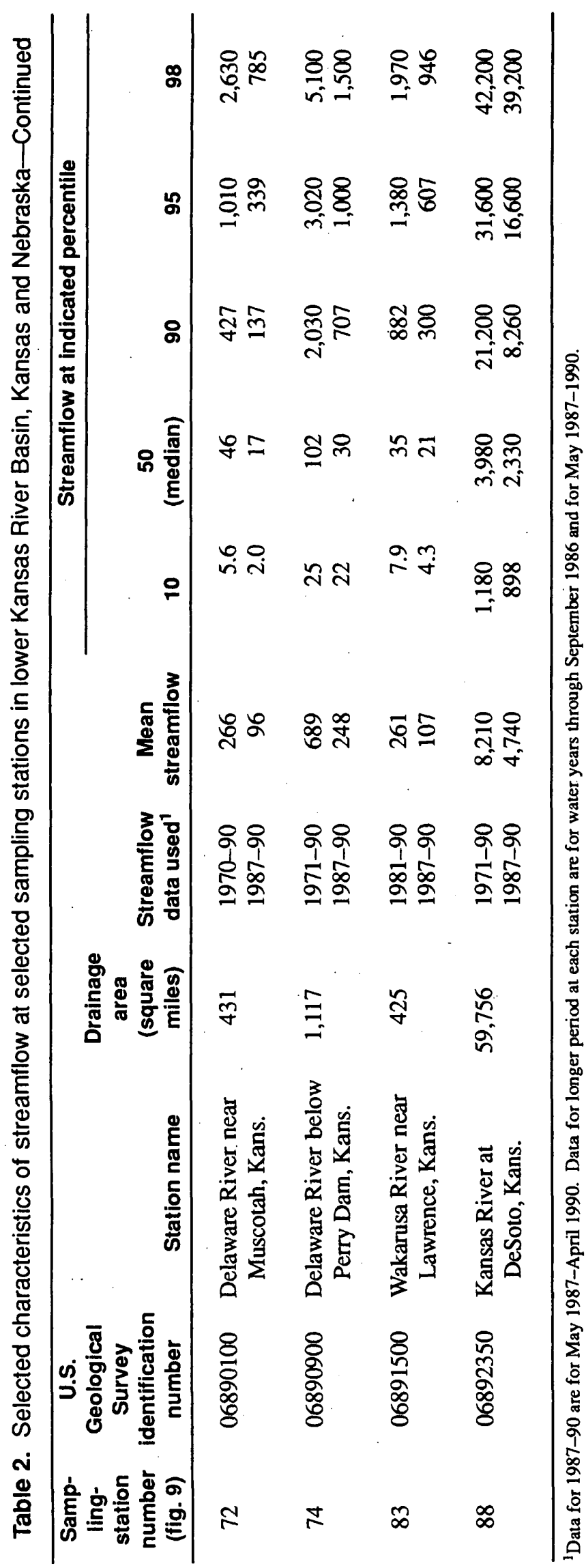

16 Surface-Water-Quality Assessment of the Lower Kansas River Basin, Kansas and Nebraska: Results of Investigations, 1987-90 


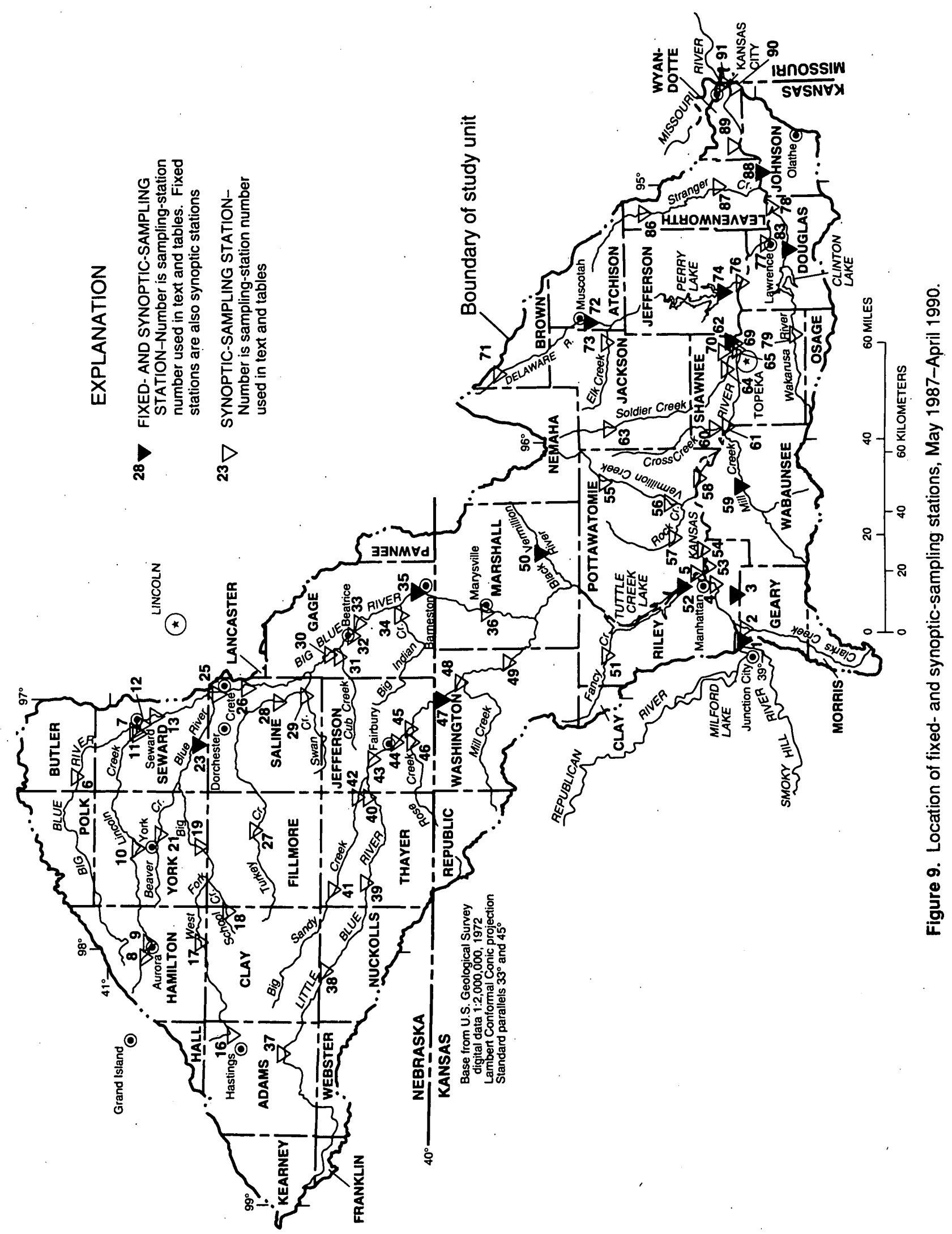




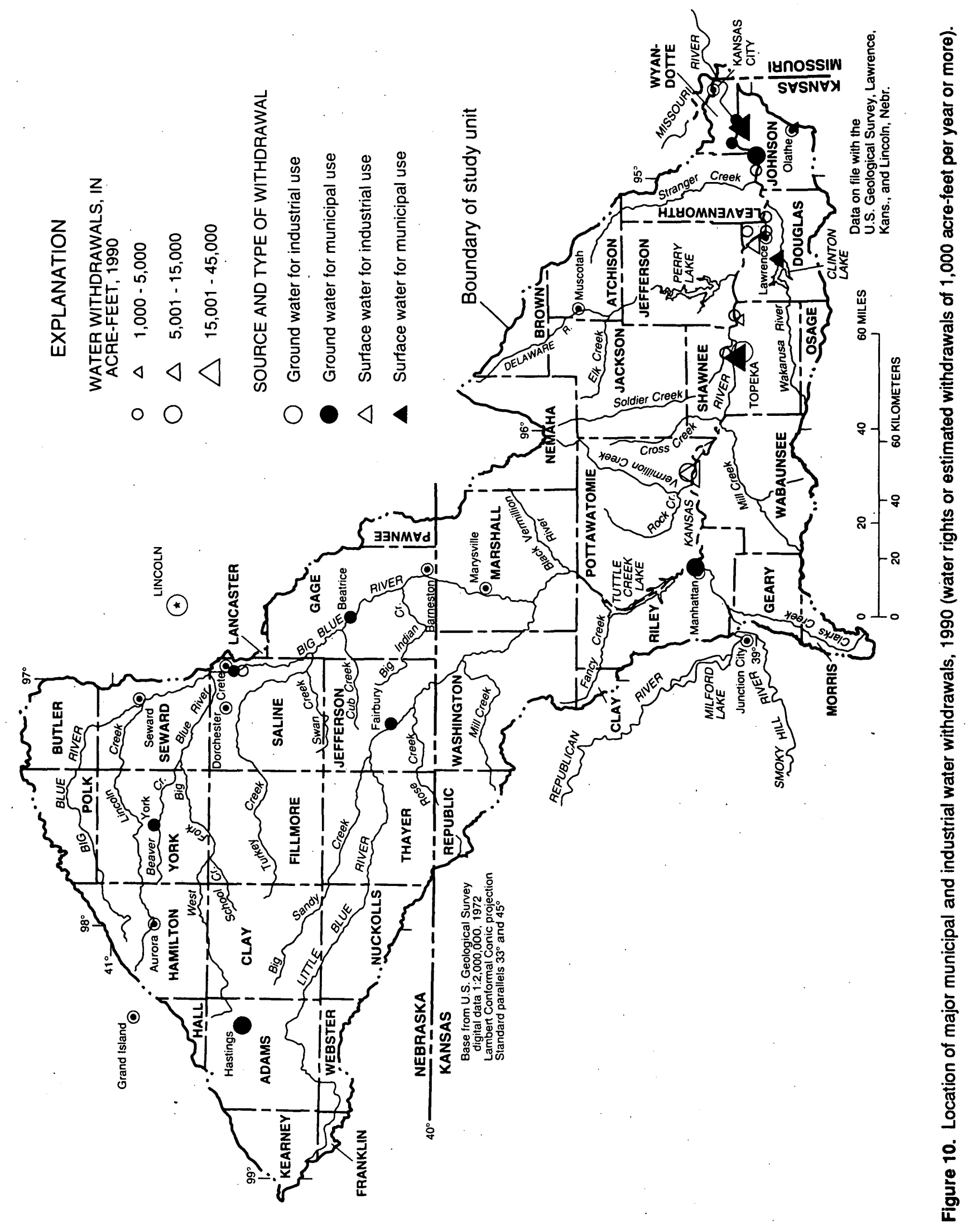

18 Surface-Water-Quality Assessment of the Lower Kansas River Basin, Kansas and Nebraska: Results of Investigatlons, 
discharge wastewater, the location of these facilities and a municipal wastewater facility $2 \mathrm{mi}$ upstream from the confluence of the Republican and Smoky Hill Rivers is shown in figure 11. Of the 28 facilities that are permitted to discharge wastewater at a rate of $1 \mathrm{Mgal} / \mathrm{d}$ or more, 16 are municipal wastewater-treatment plants (all of these provide secondary treatment) and 12 are industrial plants. Most point sources of wastewater are in the southeastern, more urbanized, part of the study unit.

\section{METHODS OF ASSESSMENT}

The NAWQA Program established methods of data collection, sample analysis, and data analysis to be used in the study units. Information on these methods is given by Fallon and McChesney (1993), Jordan (1991a), and other sources as noted in the following paragraphs. In addition, exceptions to these methods or methods applied to only a single type or class of constituent are described in the appropriate section under "Water-Quality Conditions and Trends."

A set of water-quality constituents and properties was identified that comprise the variables on which the program focused (Hirsch and others, 1988). The inorganic constituents and properties that were selected are listed in table 3.

Pre-1987 data, analyzed by Jordan and Stamer (1991) and also used in this report for trend analysis, were assembled from several sources. Sources and characteristics of these data are described in detail by Jordan (1991b).

The sections that follow refer to methods applied to the 1987-90 data collected by the U.S. Geological Survey. The sampling locations are grouped into nonexclusive categories on the basis of sampling frequency and type of sampling: fixed stations, synoptic stations, and miscellaneous stations (table 4; the fourth station type shown in the table refers to fish-tissue data not collected by the U.S. Geological Survey). Details of the purposes and selection criteria of the stations are given by Fallon and McChesney (1993). Most of the stations are not identified by any structure, except for the fixed stations which are U.S. Geological Survey streamflow-gaging stations. Fixed stations (13 locations, table 4, fig. 9) were sampled monthly or more frequently to obtain water samples representative of the range in flows. Synoptic stations (77 locations including the fixed stations, table 4, fig. 9) were sampled to assess selected waterquality conditions during low flow within short time periods (generally less than 5 days). Miscellaneous stations (14 locations) were for specialpurpose sampling, such as downstream of a particular land use. The location of miscellaneous stations are presented in Fallon and McChesney (1993, plate 1).

\section{Sample Collection}

Standardized sample-collection methods are important to obtain reliable data that can be interpreted with confidence. Depth-integrated water samples from at least three verticals in the stream cross section were obtained to minimize nonrepresentative results due to a lack of mixing and for constituents that are associated with suspended sediment. Special sampling techniques were used at some stations, as reported by Fallon and McChesney (1993).

Measurements of some properties and constituents were made onsite at the times of sampling. Specific conductance, $\mathrm{pH}$, and water temperature. were measured for every sample. Water temperature was measured using techniques outlined by Stevens and others (1975). Alkalinity was measured in all samples collected at fixed stations, and dissolved oxygen was measured in all samples collected during synoptic surveys.

Water samples for the analysis of inorganic compounds, nutrients, and suspended sediment were obtained using depth-integrating samplers and methods conforming to those developed by Guy and Norman (1970). Dissolved constituents were analyzed in sample water that had been passed through a 0.45 -micrometer filter. Samples were prepared for laboratory analysis according to the methods of Ward and Harr (1990). Samples for determination of Escherichia coli bacteria were collected using methods described by Britton and Greeson (1987). Collection of water samples for analysis of radionuclides was performed according to guidelines of Thatcher and others (1977). Samples for the analysis of organic compounds, . including pesticides, were collected using methods 


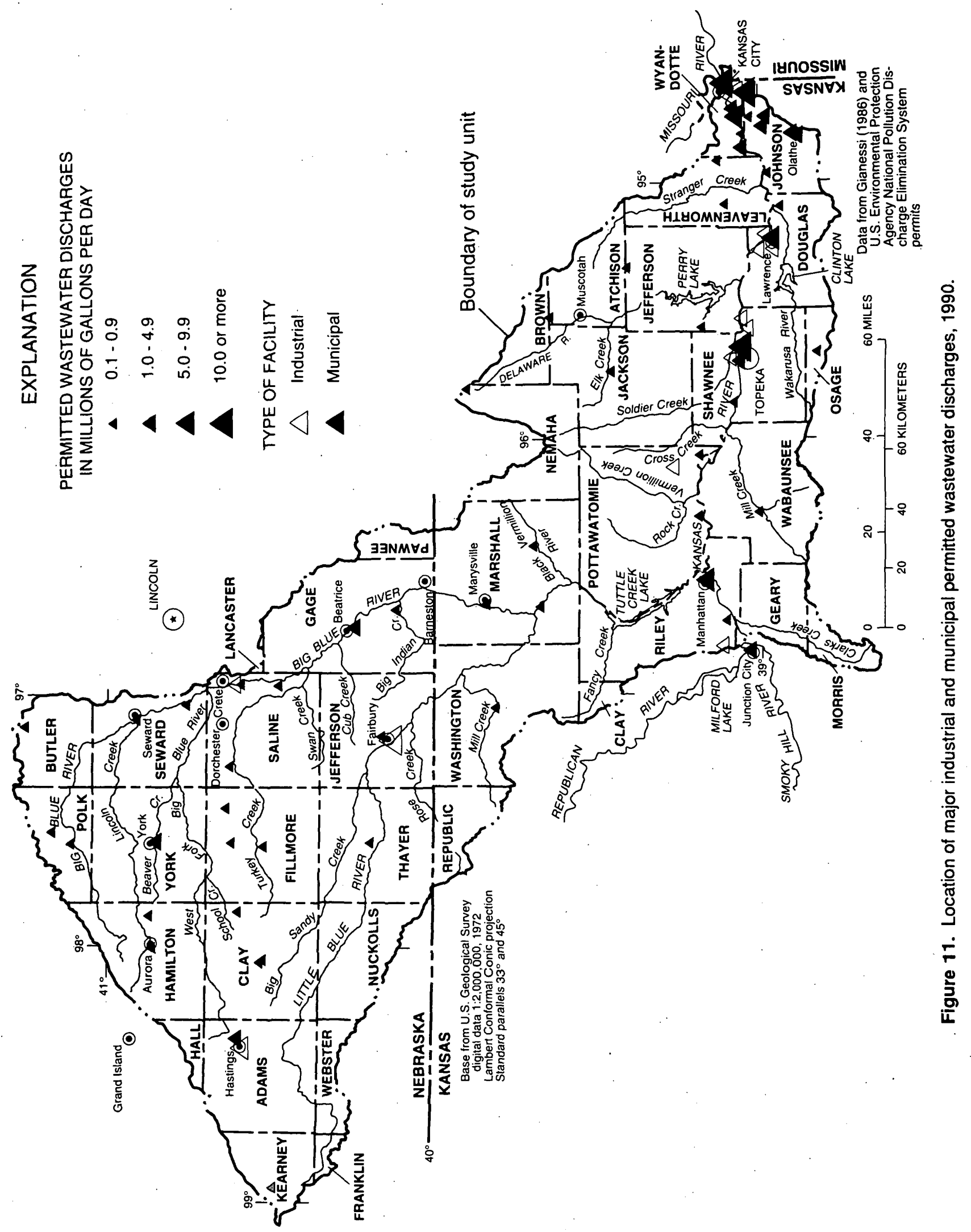

20 Surface-Water-Quality Assessment of the Lower Kansas River Basin, Kansas and Nebraska: Results of Investigations, 
Table 3. Selected inorganic constituents and properties, their association with principal environmental effects, and their association with the water-quality issues addressed by the National Water-Quality Assessment Program (NAWQA)

[Modified from Hirsch and others (1988, table 3). -, no environmental effect or association with NAWQA water-quality issues; + , environmental effect or association with NAWQA water-quality issues]

\begin{tabular}{|c|c|c|c|c|c|c|c|c|}
\hline \multirow[b]{2}{*}{$\begin{array}{c}\text { Constituent or } \\
\text { property }\end{array}$} & \multicolumn{3}{|c|}{$\begin{array}{c}\text { Princlpal environmental } \\
\text { effect }\end{array}$} & \multicolumn{5}{|c|}{ Water-quality issues } \\
\hline & $\begin{array}{l}\text { Human } \\
\text { health }\end{array}$ & $\begin{array}{l}\text { Eco- } \\
\text { systems }\end{array}$ & $\begin{array}{l}\text { Agri- } \\
\text { culture }\end{array}$ & $\begin{array}{l}\text { Toxic } \\
\text { contam- } \\
\text { ination }\end{array}$ & $\begin{array}{l}\text { Nutrlent } \\
\text { enrich- } \\
\text { ment }\end{array}$ & $\begin{array}{l}\text { Acidifi- } \\
\text { cation }\end{array}$ & Salinity & $\begin{array}{l}\text { General } \\
\text { suitability }\end{array}$ \\
\hline \multicolumn{9}{|c|}{ pH, alkalinity, and acidity } \\
\hline $\mathrm{pH}$ & - & + & - & - & - & + & - & - \\
\hline Alkalinity & - & + & - & - & - & + & + & + \\
\hline Acidity & - & + & - & - & - & + & - & - \\
\hline \multicolumn{9}{|c|}{ Dissolved solids and major ions } \\
\hline Dissolved solids & - & + & + & - & - & - & + & + \\
\hline Calcium & - & + & + & - & - & + & + & + \\
\hline Magnesium & - & + & + & - & - & + & + & + \\
\hline Sodium & + & + & + & - & - & + & + & + \\
\hline Sulfate & + & + & - & - & - & + & + & + \\
\hline Chloride & - & + & + & - & - & + & + & + \\
\hline Fluoride & + & - & - & + & - & - & - & - \\
\hline \multicolumn{9}{|c|}{ Nutrients } \\
\hline Nitrate & + & + & + & + & + & + & - & - \\
\hline Nitrite & + & + & + & + & + & - & - & - \\
\hline Ammonia & - & + & - & + & + & - & - & - \\
\hline Total nitrogen & - & + & - & - & + & - & - & - \\
\hline Total phosphorus & - & + & - & - & + & - & - & - \\
\hline Orthophosphate & - & + & - & - & + & - & - & - \\
\hline \multicolumn{9}{|c|}{ Dissolved oxygen } \\
\hline Dissolved oxygen & - & + & - & - & - & - & - & + \\
\hline \multicolumn{9}{|c|}{ Major metals and trace elements } \\
\hline Aluminum & - & + & + & + & - & + & - & - \\
\hline Antimony & + & + & - & + & - & - & - & - \\
\hline Arsenic & + & + & + & + & - & - & + & - \\
\hline Barium & + & . & - & + & - & - & - & - \\
\hline Beryllium & + & - & - & + & - & - & - & - \\
\hline Boron & - & - & + & - & - & - & + & $\therefore$ \\
\hline Cadmium & + & + & - & + & - & + & - & - \\
\hline Chromium & + & + & - & + & - & + & - & - \\
\hline Copper & - & + & + & + & - & + & - & - \\
\hline Iron & - & - & - & - & - & - & - & + \\
\hline
\end{tabular}


Table 3. Selected inorganic constituents and properties, their association with principal environmental effects, and their association with the water-quality issues addressed by the National Water-Quality Assessment Program (NAWQA) - Continued

\begin{tabular}{|c|c|c|c|c|c|c|c|c|}
\hline \multirow[b]{2}{*}{$\begin{array}{l}\text { Constituent or } \\
\text { property }\end{array}$} & \multicolumn{3}{|c|}{$\begin{array}{c}\text { Principal environmental } \\
\text { effect }\end{array}$} & \multicolumn{5}{|c|}{ Water-quality issues } \\
\hline & $\begin{array}{l}\text { Human } \\
\text { health }\end{array}$ & $\begin{array}{l}\text { Eco- } \\
\text { systems }\end{array}$ & $\begin{array}{l}\text { Agrl- } \\
\text { culture }\end{array}$ & $\begin{array}{c}\text { Toxic } \\
\text { contam- } \\
\text { Ination }\end{array}$ & $\begin{array}{c}\text { Nutrlent } \\
\text { enrich- } \\
\text { ment }\end{array}$ & $\begin{array}{l}\text { Acldifl- } \\
\text { cation }\end{array}$ & Sallnity & $\begin{array}{l}\text { General } \\
\text { sultablilty }\end{array}$ \\
\hline \multicolumn{9}{|c|}{ Major metals and trace elements-Continued } \\
\hline Lead & + & + & - & + & - & + & - & - \\
\hline Manganese & - & - & - & - & - & - & - & + \\
\hline Mercury & + & + & + & + & - & + & - & - \\
\hline Molybdenum & + & - & + & + & - & - & + & - \\
\hline Nickel & + & - & - & + & - & + & - & - \\
\hline Selenium & + & + & + & + & - & - & + & - \\
\hline Silver & - & + & - & + & - & - & - & - \\
\hline Vanadium & + & - & - & + & - & - & - & - \\
\hline Zinc & - & + & - & + & - & + & - & - \\
\hline \multicolumn{9}{|c|}{ Radionuclides } \\
\hline Gross alpha & + & - & - & + & - & - & - & - \\
\hline Gross beta & + & - & - & + & - & - & - & - \\
\hline
\end{tabular}




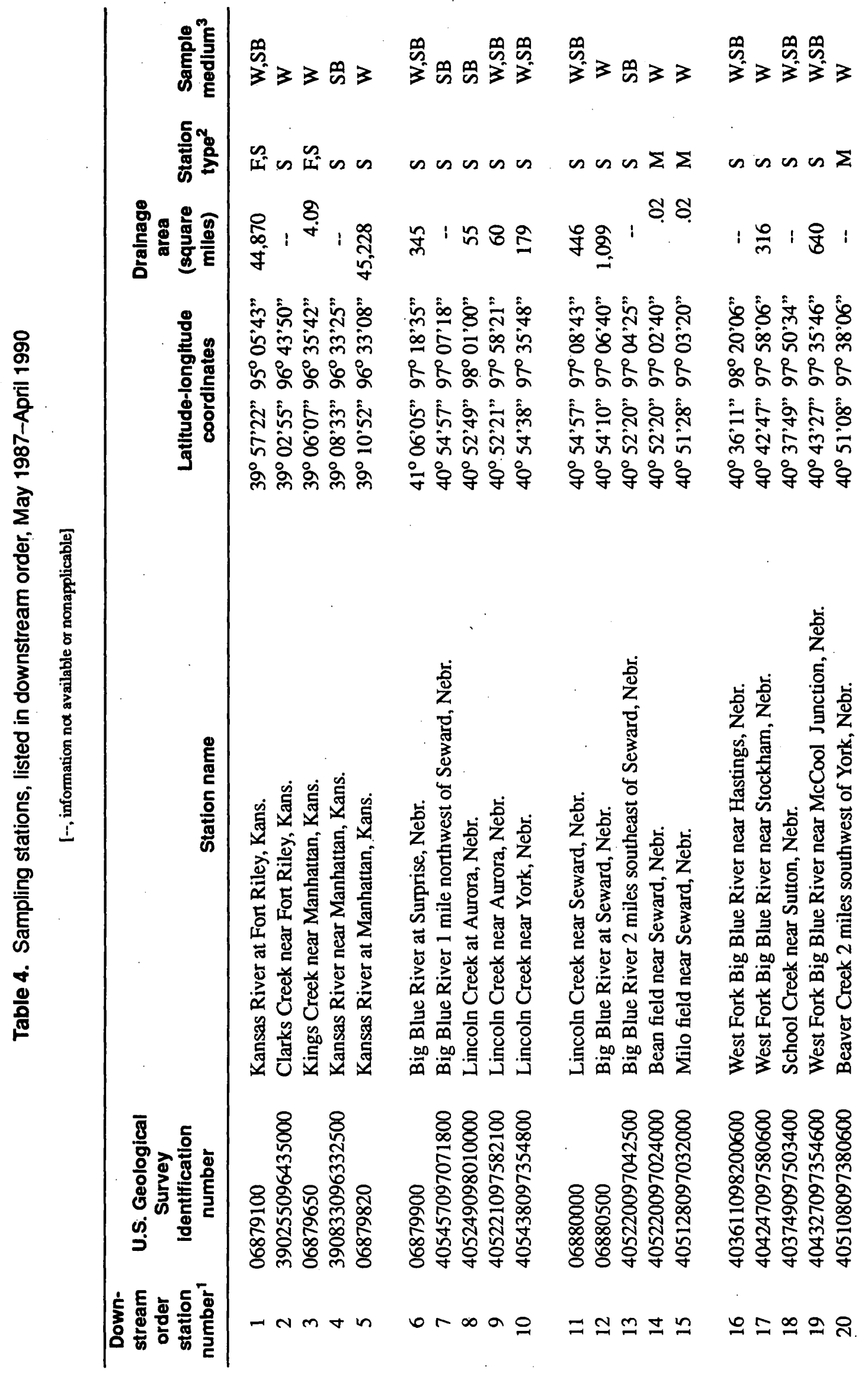




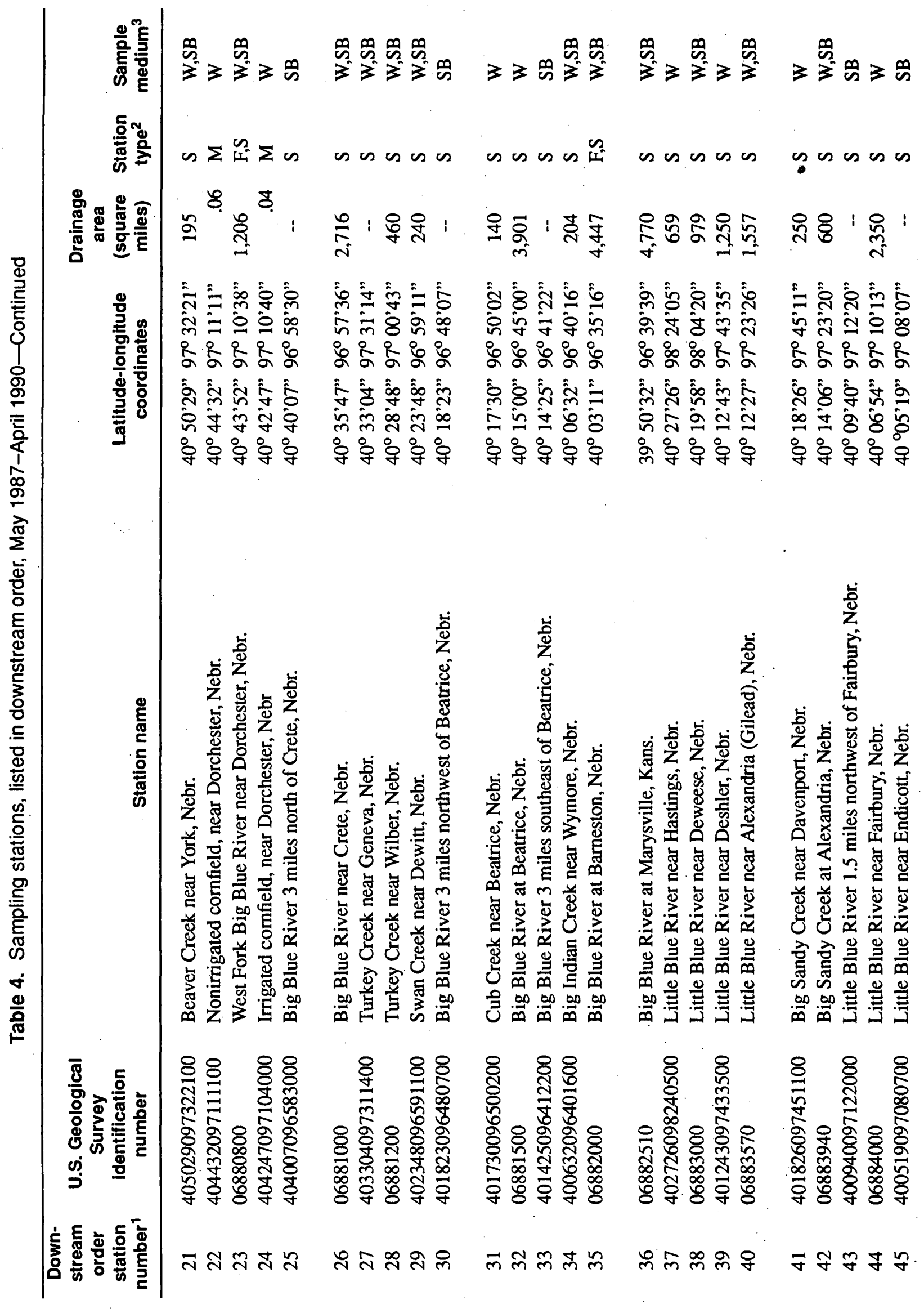

24 Surface-Water-Quality Assessment of the Lower Kansas River Basin, Kansas and Nebraska: Results of Investigations, 


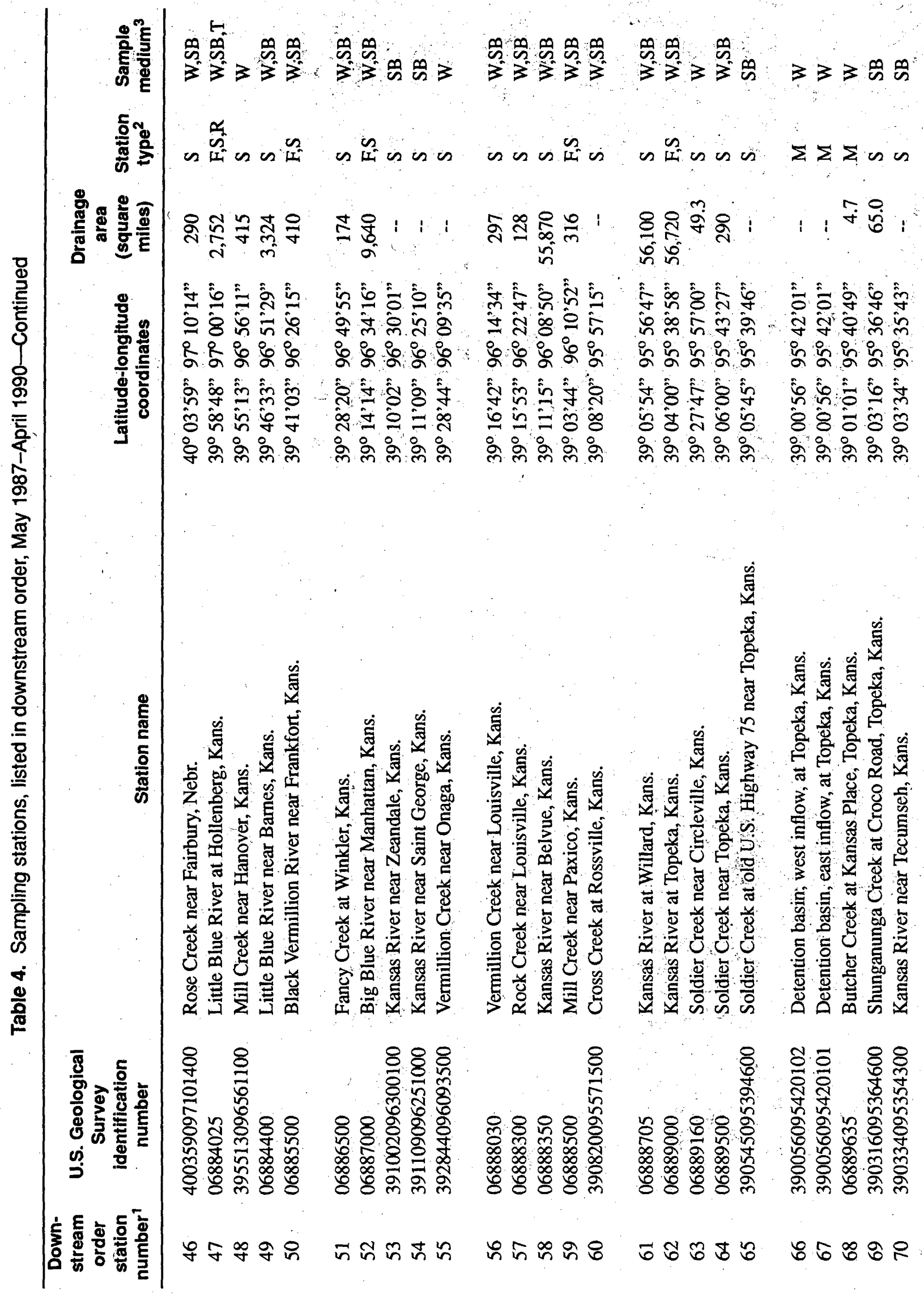




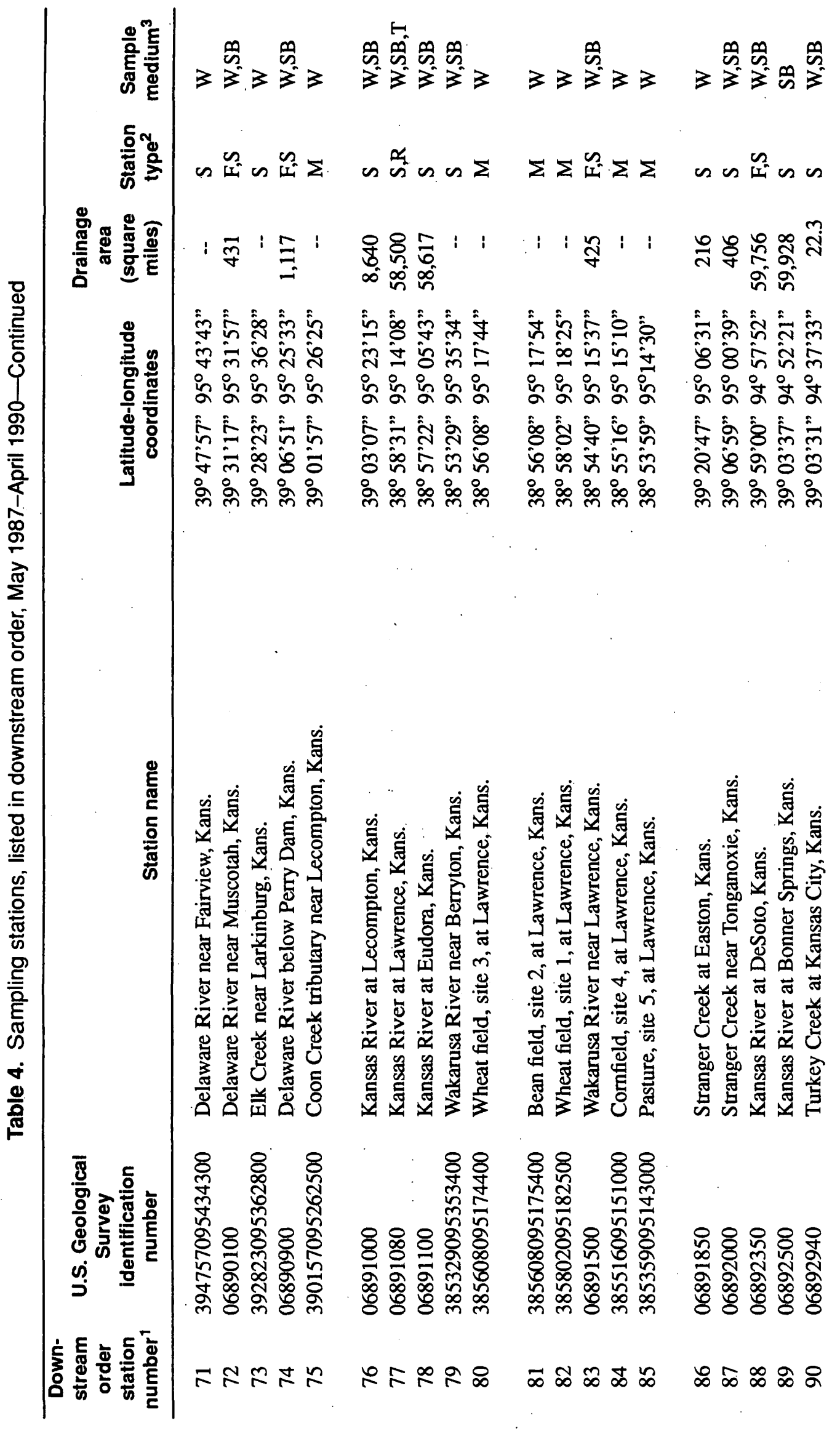

26 Surface-Water-Quality Assessment of the Lower Kansas River Basin, Kansas and Nebraska: Results of Investigations, 1987-90 


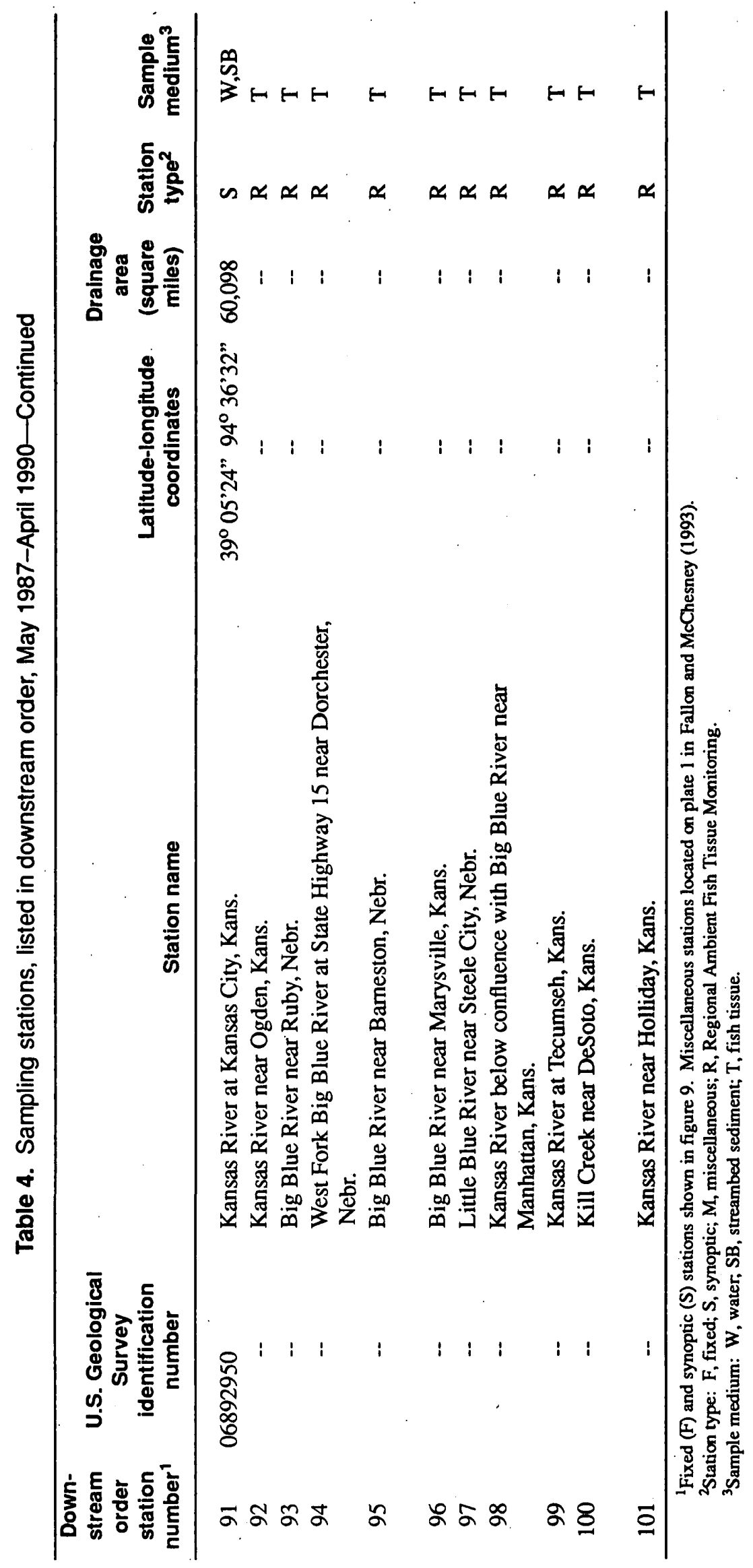


described by Goerlitz and Brown (1972) and Wershaw and others (1987). Streambed-sediment samples for the analyses of metals and trace elements were collected as described by Tanner and others (1990), in accordance with procedures of Arbogast (1990). Samples for analysis of traceorganic compounds in streambed sediment were collected using a protocol by J.A. Colman (U.S. Geological Survey, written commun., July 30,1987$)$.

\section{Analytical Methods}

All sample analyses were performed by the U.S. Geological Survey's National Water-Quality Laboratory in Arvada, Colo., unless otherwise noted below. Inorganic compounds in water, including major and minor ions and nutrients, were analyzed using methods compiled by Fishman and Friedman (1989). Three of the fixed stations were operated in cooperation with the Kansas Department of Health and Environment (KDHE); routine monthly laboratory analyses of samples from those stations were divided between the KDHE and the U.S. Geological Survey. Some additional analyses were performed by the KDHE for the determination of trace metals and nutrients in water.

Escherichia coli sample colonies were prepared and evaluated using the membrane-filter procedure endorsed by the U.S. Environmental Protection Agency (1985a). Radionuclides were analyzed using methods summarized by Thatcher and others (1977). Organic compounds, including pesticides, were determined using methods described by Wershaw and others (1987). Most streambed samples were analyzed by the U.S. Geological Survey, Branch of Geochemistry Laboratories in Denver, Colo. Streambed samples collected during a synoptic survey in April 1989 (Fallon and McChesney, 1993) were analyzed by the Tennessee Valley Authority.

Methods of quality assurance, as described by Fallon and McChesney (1993), were practiced to: (1) collect water samples representative of streamflow; (2) minimize the risk of sample contamination and mix-up; and (3) verify accurate analytical results. Sample-collection procedures conformed to Sanzolone and Ryder (1989). Quality-assurance samples, including standard reference samples, duplicates, replicates, blanks, equipment blanks, trip blanks, and spikes, were incorporated into approximately 21 percent of all samples submitted for analysis. Fallon and McChesney (1993) described procedures used to review the validity of analytical results.

\section{Data Analysis}

This section describes the methods used to assess current (1987-90) water-quality conditions (concentrations and transport) and for the analysis of long-term trends. Data collected from May 1987 through April 1990 are presented by Fallon and McChesney (1993) and Tanner and others (1990). Analysis of these data was facilitated by the use of a geographic information system (Zelt, 1991).

Most constituent concentrations and other water-quality measurements at each station are presented as selected percentiles to indicate the central tendency and the typical variation of the data. The median was selected as the measure of central tendency of the data because it is insensitive to extreme values. The 25 th and 75 th percentiles span the central one-half of the data values and provide information on both central tendency and variation. The 10th and 90 th percentiles provide a reasonable estimate of the typical variation of the data because they account for all but the most extreme 10 percent at each end of the distribution.

An adequate number of analyses are needed to represent conditions during a selected time period. An arbitrary convention, described by Jordan (1991a), was adopted for this assessment whereby the 25 th, 50 th, and 75 th percentiles were calculated only if 10 or more analyses were available, and the 10th and 90th percentiles were calculated only if 30 or more analyses were available. The summary tables presented later in this report show the number of analyses, in addition to the percentiles, to aid in judging the adequacy of the data. Important points pertaining to sample randomness and bias also are discussed by Jordan (1991a).

To compare the available data with waterquality criteria for either instream or offstream use, the "Water Quality Criteria Summary" chart 
included in a report by the U.S. Environmental Protection Agency (1987), or updated information for particular constituents, was used. Because some criteria are for averages of analyses during specified times and the criteria for drinking water are for treated water rather than for raw water, the analyses of individual instantaneous samples of ambient water quality are not directly comparable with the U.S. Environmental Protection Agency criteria.

State water-quality criteria of Kansas or Nebraska exist for some constituents or properties not covered by U.S. Environmental Protection Agency criteria. Some State criteria also differ from U.S. Environmental Protection Agency criteria either in the numerical value, in the method of averaging, or in frequency of occurrence. In addition, State criteria of Kansas and Nebraska are not identical. Therefore, only the U.S. Environmental Protection Agency criteria are reported herein, except as noted in particular parts of this report.

Transport rates and yields at the 13 fixed stations (fig. 9, table 4) were calculated for selected constituents. "Transport rate" as used in this report is the rate at which a constituent passes a section of a stream, in units of dry weight per unit time. "Yield" is the transport rate per unit of drainage area. Determinations of mean annual transport rates were made as described by Jordan (1991a) and involved least-squares regressions using the logarithm of transport rate, the logarithm of streamflow rate, and seasonal factors calculated as trigonometric functions of the date. A measure of the accuracy (the root-mean-square error) of the estimate of mean annual transport rate was calculated by a method that accounted for the standard errors of the regression coefficients, the number of days involved in the estimated mean, and the serial correlation of daily values. The percentage of transport rate calculated from streamflow values larger than those used to establish the relation between transport rate and streamflow was determined as an indication of the uncertainty of the estimated transport. Where yield is shown, the same percentage applies.

Long-term trends were tested using the seasonal Kendall test (Hirsch and others, 1982). The analysis of long-term trends used data from earlier years in addition to the data collected from May 1987 through April 1990. Where data were adequate for the analysis, all available data on the constituent at each sampling station were used, with the exception of replicate samples on the same day and data extremely isolated in time from the main body of data.

The judgment regarding the adequacy of available data for analysis of long-term trends was partly subjective. Minimum requirements applied were: (1) at least 40 analyses; (2) at least 10 years from first year to last year of data used; and (3) a year would not be counted as the first or last of the 10 years if there were fewer than three analyses in that year. Further explanation on the data requirements, consideration of data by season, and adjustments of some constituents in relation to streamflow or serial correlation are given by P.R. Jordan (1991a) and Schertz and others (1991).

Results of all tests for trend, whether statistically significant or not, are shown in this report and include the probability level and the average rate of change of concentration, as described by Jordan (1991a). The standard for statistical significance for trend of an individual constituent at a specific station was established as a probability level of 0.10 or less; however, a probability level greater than 0.10 does not necessarily show that no trend existed, only that the evidence was insufficient to reject the hypothesis that no trend existed. Test results with probability levels greater than 0.10 may be meaningful if consistent with results for other constituents or other sampling stations, or other relevant information. The average rate of change of concentration, in units per year or percent, was calculated for all analyses. Rates expressed as percentages were used appropriately to judge only whether a statistically significant trend had practical significance. The rate calculated is only an average of rates that may have varied considerably during the period of data used, and in some cases, the calculated rate varies considerably when slightly different periods of data are used. Both the probability level and the rate apply only to the period of the analysis and should not be used for projections beyond that period. 


\section{WATER-QUALITY CONDITIONS AND TRENDS}

Water-quality conditions and trends are described in the following sections according to major classes of chemical constituents.

\section{Dissolved Solids and Major lons by J.D. Fallon and P.R. Jordan}

Dissolved solids primarily are the cations calcium, magnesium, sodium, and potassium and the anions bicarbonate, carbonate, sulfate, and chloride. Concentrations of dissolved ions in water reflect the types of rock and soil in the area (figs. 3 and 4). Water in contact with the rocks and soils may dissolve certain ions, which increases their concentration in water.

Human activities also may affect the concentrations of major ions in water. Most land in the lower Kansas River Basin is used for agriculture, which can affect ion concentrations in several ways. Irrigation return flows often have larger concentrations of major ions than the water applied because evaporation and transpiration concentrate ions remaining in the water. Soil-conservation practices, which increase the amount of time water is in contact with soil, also may increase major-ion concentrations. Runoff from cultivated fields has increased levels of some ions, such as potassium from fertilizer. Activities such as mining or quarrying may expose minerals, accelerate weathering and dissolution, and result in increased concentrations of major ions in water. Salt applied to deice roads in winter dissolves readily in water, thereby increasing sodium and chloride concentrations. Water from industrial and public wastewatertreatment facilities also may contain increased levels of major ions such as chloride.

The concentration at which a particular major ion becomes a concern to humans depends on the intended use of the water. Secondary Maximum Contaminant Levels (SMCL's) for drinking water (those established for constituents that can adversely affect the odor or appearance of water) exist for dissolved solids $(500 \mathrm{mg} / \mathrm{L})$, chloride $(250 \mathrm{mg} / \mathrm{L})$, and sulfate $(250 \mathrm{mg} / \mathrm{L})$ (U.S. Environmental Protection Agency, 1990). Salt (sodium chloride) concentrations in irrigation water may inhibit plant growth directly by making osmosis more difficult, or indirectly by changing the structure, permeability, and aeration of a soil. Plant tolerances to salt vary considerably although most crops grown in the study unit, such as corn, wheat, and sorghum, are considered semitolerant (Todd, 1980).

Industrial water users also have various waterquality needs that relate to major ions. Dissolved solids can cause increased corrosion of industrial equipment by increasing the electrical conductivity of the water. Calcium and magnesium can precipitate as scale in boilers, thereby decreasing their efficiency. Total hardness also may affect the amounts of detergents and chemicals needed to perform their functions properly and may result in increased production costs.

In this study, surface water was sampled for dissolved major ions at least monthly at 12 of the 13 fixed stations (table 4, fig. 9): Kings Creek near Manhattan, Kans. (station 3), was not sampled monthly because periodically there was no flow. This frequency of sample collection throughout the range of flows allowed assessment of variations in concentrations of major ions as well as of the loads of dissolved solids that were transported by the major tributaries. Trends in major-ion concentrations also were evaluated.

\section{Concentrations}

Statistical summaries of concentrations of dissolved solids and major ions for the 13 fixed stations are presented in table 5 . The number of analyses used for most computations at each station generally ranged from 24 to 45 ; fewer than 30 analyses were available for Kings Creek near Manhattan, Kans. (station 3).

Dissolved-solids concentrations that exceed $500 \mathrm{mg} / \mathrm{L}$ may be of concern for public-water supplies and for the irrigation of sensitive crops. Concentrations from fixed stations on the Kansas River (stations 1, 62, and 88) exceeded that value in more than one-half of the samples collected. In comparison, stations on most tributaries to the Kansas River exceeded that level in less than one-tenth of the samples collected.

Total hardness in water results mostly from the presence of calcium and magnesium (Hem, 1985). More than three-fourths of all water samples from 
Table 5. Statistical summary of data for dissolved solids and major ions in water from fixed stations in lower Kansas River Basin, Kansas and Nebraska, May 1987-April 1990

[Concentrations in milligrams per liter; this table includes only those stations having 10 or more analyses; --, the 10- and 90-percentile values are not shown for stations having fewer than 30 analyses]

\begin{tabular}{|c|c|c|c|c|c|c|c|}
\hline \multirow[b]{2}{*}{$\begin{array}{c}\text { Station } \\
\text { number } \\
\text { (fig. 9) }\end{array}$} & \multirow[b]{2}{*}{ Station name } & \multirow[b]{2}{*}{$\begin{array}{c}\text { Number } \\
\text { of } \\
\text { analyses }\end{array}$} & \multicolumn{5}{|c|}{ Value at indicated percentile } \\
\hline & & & 10 & 25 & $\begin{array}{c}50 \text { (me- } \\
\text { dian) }\end{array}$ & 75 & 90 \\
\hline \multicolumn{8}{|c|}{ Dissolved solids, residue at 180 degrees Celsius } \\
\hline 1 & Kansas River at Fort Riley, Kans. & 39 & 340 & 640 & 880 & 1,100 & 1,200 \\
\hline 3 & Kings Creek near Manhattan, Kans. & 24 & -- & 210 & 310 & 320 & -- \\
\hline 23 & West Fork Big Blue River near Dorchester, Nebr. & 43 & 120 & 300 & 360 & 400 & 410 \\
\hline 35 & Big Blue River at Barneston, Nebr. & 41 & 170 & 310 & 400 & 460 & 480 \\
\hline 47 & Little Blue River at Hollenberg, Kans. & 40 & 150 & 290 & 340 & 360 & 410 \\
\hline 50 & Black Vermillion River near Frankfort, Kans. & 42 & 200 & 300 & 360 & 380 & 390 \\
\hline 52 & Big Blue River near Manhattan, Kans. & 37 & 200 & 260 & 330 & 350 & 370 \\
\hline 59 & Mill Creek near Paxico, Kans. & 35 & 230 & 340 & 400 & 440 & 500 \\
\hline 62 & Kansas River at Topeka, Kans. & 38 & 320 & 430 & 550 & 630 & 720 \\
\hline 72 & Delaware River near Muscotah, Kans. & 37 & 270 & 330 & 380 & 440 & 600 \\
\hline 74 & Delaware River below Perry Dam, Kans. & 32 & 180 & 200 & 220 & 230 & 240 \\
\hline 83 & Wakarusa River near Lawrence, Kans. & 33 & 180 & 190 & 210 & 240 & 270 \\
\hline 88 & Kansas River at DeSoto, Kans. & 38 & 330 & 430 & 530 & 620 & 690 \\
\hline \multicolumn{8}{|c|}{ Hardness, total, as $\mathrm{CaCO}_{3}$} \\
\hline 1 & Kansas River at Fort Riley, Kans. & 39 & 140 & 270 & 310 & 400 & 430 \\
\hline 3 & Kings Creek near Manhattan, Kans. & 24 & -- & 180 & 300 & 320 & -- \\
\hline 23 & West Fork Big Blue River near Dorchester, Nebr. & 45 & 39 & 180 & 220 & 250 & 260 \\
\hline 35 & Big Blue River at Barneston, Nebr. & 41 & 85 & 170 & 220 & 260 & 290 \\
\hline 47 & Little Blue River at Hollenberg, Kans. & 40 & 75 & 160 & 200 & 220 & 240 \\
\hline 50 & Black Vermillion River near Frankfort, Kans. & 41 & 92 & 220 & 260 & 280 & 290 \\
\hline 52 & Big Blue River near Manhattan, Kans. & 37 & 140 & 180 & 210 & 230 & 250 \\
\hline 59 & Mill Creek near Paxico, Kans. & 39 & 220 & 290 & 320 & 380 & 420 \\
\hline 62 & Kansas River at Topeka, Kans. & 37 & 170 & 200 & 260 & 300 & 320 \\
\hline 72 & Delaware River near Muscotah, Kans. & 38 & 200 & 240 & 270 & 300 & 380 \\
\hline 74 & Delaware River below Perry Dam, Kans. & 33 & 130 & 150 & 170 & 180 & 180 \\
\hline 83 & Wakarusa River near Lawrence, Kans. & 35 & 130 & 150 & 160 & 180 & 200 \\
\hline 88 & Kansas River at DeSoto, Kans. & 39 & 150 & 200 & 250 & 280 & 310 \\
\hline \multicolumn{8}{|c|}{ Noncarbonate hardness as $\mathrm{CaCO}_{3}$} \\
\hline 1 & Kansas River at Fort Riley, Kans. & 34 & 30 & 91 & 120 & 160 & 180 \\
\hline 3. & Kings Creek near Manhattan, Kans. & 21 & -- & 14 & 23 & 29 & -- \\
\hline 23 & West Fork Big Blue River near Dorchester, Nebr. & 29 & -- & 9.5 & 17 & 24 & -- \\
\hline
\end{tabular}


Table 5. Statistical summary of data for dissolved solids and major ions in water from fixed stations in lower Kansas River Basin, Kansas and Nebraska, May 1987-April 1990-Continued

\begin{tabular}{|c|c|c|c|c|c|c|c|}
\hline \multirow[b]{2}{*}{$\begin{array}{c}\text { Station } \\
\text { number } \\
\text { (fig. 9) }\end{array}$} & \multirow[b]{2}{*}{ Station name } & \multirow[b]{2}{*}{$\begin{array}{c}\text { Number } \\
\text { of } \\
\text { analyses }\end{array}$} & \multicolumn{5}{|c|}{ Value at indicated percentlle } \\
\hline & & & 10 & 25 & $\begin{array}{c}50 \text { (me- } \\
\text { dian) }\end{array}$ & 75 & 90 \\
\hline \multicolumn{8}{|c|}{ Noncarbonate hardness as $\mathrm{CaCO}_{3}-$ Continued } \\
\hline 35 & Big Blue River at Barneston, Nebr. & 37 & 6.8 & 12 & 22 & 30 & 37 \\
\hline 47 & Little Blue River at Hollenberg, Kans. & 35 & 3.6 & 7.0 & 14 & 19 & 26 \\
\hline 52 & Big Blue River near Manhattan, Kans. & 28 & -- & 14 & 20 & 24 & -- \\
\hline 59 & Mill Creek near Paxico, Kans. & 35 & 35 & 49 & 80 & 110 & 130 \\
\hline 62 & Kansas River at Topeka, Kans. & 28 & -- & 47 & 66 & 90 & -- \\
\hline 72 & Delaware River near Muscotah, Kans. & 29 & -- & 28 & 45 & 84 & - \\
\hline 74 & Delaware River below Perry Dam, Kans. & 13 & -- & 3.5 & 10 & 14 & -- \\
\hline 83 & Wakarusa River near Lawrence, Kans. & 26 & -- & 6.7 & 12 & 20 & -- \\
\hline 84 & Kansas River at DeSoto, Kans. & 32 & 20 & 38 & 58 & 72 & 110 \\
\hline \multicolumn{8}{|c|}{ Calcium, dissolved } \\
\hline 1 & Kansas River at Fort Riley, Kans. & 39 & 44 & 76 & 88 & 110 & 120 \\
\hline 3 & Kings Creek near Manhattan, Kans. & 24 & -- & 58 & 90 & 97 & -- \\
\hline 23 & West Fork Big Blue River near Dorchester, Nebr. & 45 & 11 & 52 & 68 & 78 & 80 \\
\hline 35 & Big Blue River at Barneston, Nebr. & 41 & 24 & 48 & 64 & 78 & 85 \\
\hline 47 & Little Blue River at Hollenberg, Kans. & 40 & 24 & 51 & 62 & 68 & 76 \\
\hline 50 & Black Vermillion River near Frankfort, Kans. & 41 & 28 & 66 & 74 & 80 & 85 \\
\hline 52 & Big Blue River near Manhattan, Kans. & 37 & 39 & 52 & 58 & 64 & 75 \\
\hline 59 & Mill Creek near Paxico, Kans. & 39 & 68 & 83 & 91 & 110 & 120 \\
\hline 62 & Kansas River at Topeka, Kans. & 37 & 45 & 56 & 72 & 83 & 94 \\
\hline 72 & Delaware River near Muscotah, Kans. & 38 & 54 & 66 & 77 & 88 & 110 \\
\hline 74 & Delaware River below Perry Dam, Kans. & 33 & 37 & 44 & 48 & 51 & 52 \\
\hline 83 & Wakarusa River near Lawrence, Kans. & 35 & 39 & 43 & 50 & 55 & 64 \\
\hline 88 & Kansas River at DeSoto, Kans. & 39 & 43 & 54 & 71 & 81 & 91 \\
\hline \multicolumn{8}{|c|}{ Magnesium, dissolved } \\
\hline 1 & Kansas River at Fort Riley, Kans. & 39 & 9.5 & 17 & 24 & 27 & 31 \\
\hline 3 & Kings Creek near Manhattan, Kans. & 24 & -- & 9.9 & 18 & 19 & -- \\
\hline 23 & West Fork Big Blue River near Dorchester, Nebr. & 45 & 2.8 & 9.9 & 13 & 14 & 15 \\
\hline 35 & Big Blue River at Barneston, Nebr. & 41 & 5.5 & 11 & 15 & 17 & 18 \\
\hline 47 & Little Blue River at Hollenberg, Kans. & 40 & 3.8 & 8.4 & 9.8 & 11 & 11 \\
\hline 50 & Black Vermillion River near Frankfort, Kans. & 42 & 5.9 & 14 & 17 & 19 & 20 \\
\hline 52 & Big Blue River near Manhattan, Kans. & 37 & 8.7 & 11 & 16 & 17 & 18 \\
\hline 59 & Mill Creek near Paxico, Kans. & 39 & 13 & 19 & 22 & 27 & 30 \\
\hline 62 & Kansas River at Topeka, Kans. & 37 & 9.8 & 16 & 19 & 23 & 25 \\
\hline
\end{tabular}


Table 5. Statistical summary of data for dissolved solids and major ions in water from fixed stations in lower Kansas River Basin, Kansas and Nebraska, May 1987-April 1990-Continued

\begin{tabular}{|c|c|c|c|c|c|c|c|}
\hline \multirow[b]{2}{*}{$\begin{array}{c}\text { Station } \\
\text { number } \\
\text { (flg. 9) }\end{array}$} & \multirow[b]{2}{*}{ Station name } & \multirow[b]{2}{*}{$\begin{array}{c}\text { Number } \\
\text { of } \\
\text { analyses }\end{array}$} & \multicolumn{5}{|c|}{ Value at indicated percentile } \\
\hline & & & 10 & 25 & $\begin{array}{c}50 \text { (me- } \\
\text { dlan) }\end{array}$ & 75 & 90 \\
\hline \multicolumn{8}{|c|}{ Magnesium, dissolved_Continued } \\
\hline 72 & Delaware River near Muscotah, Kans. & 38 & 13 & 16 & 19 & 22 & 25 \\
\hline 74 & Delaware River below Perry Dam, Kans. & 34 & 9.0 & 9.8 & 11 & 12 & 12 \\
\hline 83 & Wakarusa River near Lawrence, Kans. & 35 & 8.3 & 8.7 & 9.5 & 10 & 11 \\
\hline 88 & Kansas River at DeSoto, Kans. & 39 & 9.2 & 14 & 17 & 21 & 22 \\
\hline \multicolumn{8}{|c|}{ Sodium, dissolved } \\
\hline 1 & Kansas River at Fort Riley, Kans. & 39 & 56 & 100 & 160 & 220 & 260 \\
\hline 3 & Kings Creek near Manhattan, Kans. & 24 & -- & 3.2 & 5.3 & 5.6 & $\therefore$ \\
\hline 23 & West Fork Big Blue River near Dorchester, Nebr. & 45 & 5.2 & 22 & 32 & 36 & 39 \\
\hline 35 & Big Blue River at Barneston, Nebr. & 41 & 13 & 34 & 50 & 57 & 63 \\
\hline 47 & Little Blue River at Hollenberg, Kans. & 40 & 9.4 & 28 & 39 & 43 & .51 \\
\hline 50 & Black Vermillion River near Frankfort, Kans. & 41 & 8.4 & 20 & 28 & 32 & 33 \\
\hline 52 & Big Blue River near Manhattan, Kans. & 36 & 15 & 20 & 30 & 37 & 41 \\
\hline 59 & Mill Creek near Paxico, Kans. & 39 & 7.3 & 10 & 14 & 18 & 21 \\
\hline 62 & Kansas River at Topeka, Kans. & 37 & 37 & 62 & 86 & 120 & 140 \\
\hline 72 & Delaware River near Muscotah, Kans. & 38 & 17 & 23 & 28 & 38 & 45 \\
\hline 74 & Delaware River below Perry Dam, Kans. & 33 & 10 & 12 & 13 & 16 & 17 \\
\hline 83 & Wakarusa River near Lawrence, Kans. & 35 & 9.1 . & 9.6 & 11 & 14 & 17 \\
\hline 88 & Kansas River at DeSoto, Kans. & 39 & 27 & 62 & 76 & 110 & 120 \\
\hline \multicolumn{8}{|c|}{ Potassium, dissolved } \\
\hline 1 & Kansas River at Fort Riley, Kans. & 37 & 8.5 & 9.0 & 9.6 & 11 & 11 \\
\hline 3 & Kings Creek near Manhattan, Kans. & 24 & -- & .9 & 1.1 & 2.6 & -- \\
\hline 23 & West Fork Big Blue River near Dorchester, Nebr. & 43 & 7.5 & 7.8 & 8.9 & 10 & 12 \\
\hline 35 & Big Blue River at Barneston, Nebr. & 41 & 6.8 & 7.4 & 8.2 & 9.5 & 10 \\
\hline 47 & Little Blue River at Hollenberg, Kans. & 40 & 5.8 & 6.3 & 6.9 & 9.0 & 9.9 \\
\hline 50 & Black Vermillion River near Frankfort, Kans. & 42 & 2.5 & 3.1 & 3.9 & 4.7 & 5.5 \\
\hline 52 & Big Blue River near Manhattan, Kans. & 37 & 6.0 & 6.7 & 7.1 & 7.5 & 8.0 \\
\hline 59 & Mill Creek near Paxico, Kans. & 40 & 2.0 & 2.4 & 2.7 & 3.1 & 3.9 \\
\hline 62 & Kansas River at Topeka, Kans. & 38 & 6.7 & 7.3 & 8.1 & 8.9 & 9.4 \\
\hline 72 & Delaware River near Muscotah, Kans. & 36 & 2.9 & 3.4 & 4.3 & 5.1 & 6.0 \\
\hline 74 & Delaware River below Perry Dam, Kans. & 32 & 3.2 & 3.4 & 3.6 & 3.9 & 4.4 \\
\hline 83 & Wakarusa River near Lawrence, Kans. & 33 & 2.8 & 3.1 & 3.4 & 3.7 & 4.2 \\
\hline 88 & Kansas River at DeSoto, Kans. & 39 & 5.5 & 6.8 & 7.7 & 8.5 & 9.2 \\
\hline
\end{tabular}


Table 5. Statistical summary of data for dissolved solids and major ions in water from fixed stations in lower Kansas River Basin, Kansas and Nebraska, May 1987-April 1990-Continued

\begin{tabular}{|c|c|c|c|c|c|c|c|}
\hline \multirow[b]{2}{*}{$\begin{array}{c}\text { Station } \\
\text { number } \\
\text { (flg. 9) }\end{array}$} & \multirow[b]{2}{*}{ Station name } & \multirow[b]{2}{*}{$\begin{array}{c}\text { Number } \\
\text { of } \\
\text { analyses }\end{array}$} & \multicolumn{5}{|c|}{ Value at indicated percentile } \\
\hline & & & 10 & 25 & $\begin{array}{c}50 \text { (me- } \\
\text { dlan })\end{array}$ & 75 & 90 \\
\hline \multicolumn{8}{|c|}{ Bicarbonate, as $\mathrm{HCO}_{3}$} \\
\hline 1 & Kansas River at Fort Riley, Kans. & 35 & 150 & 170 & 220 & 260 & 320 \\
\hline 3 & Kings Creek near Manhattan, Kans. & 22 & -- & 200 & 340 & 360 & -- \\
\hline 23 & West Fork Big Blue River near Dorchester, Nebr. & 35 & 42 & 190 & 250 & 280 & 300 \\
\hline 35 & Big Blue River at Barneston, Nebr. & 37 & 92 & 190 & 230 & 270 & 300 \\
\hline 47 & Little Blue River at Hollenberg, Kans. & 36 & 110 & 190 & 220 & 240 & 270 \\
\hline 50 & Black Vermillion River near Frankfort, Kans. & 35 & 230 & 290 & 330 & 360 & 380 \\
\hline 52 & Big Blue River near Manhattan, Kans. & 36 & 170 & 180 & 200 & 240 & 280 \\
\hline 59 & Mill Creek near Paxico, Kans. & 37 & 200 & 240 & 290 & 320 & 360 \\
\hline 62 & Kansas River at Topeka, Kans. & 34 & 130 & 160 & 210 & 230 & 250 \\
\hline 72 & Delaware River near Muscotah, Kans. & 32 & 180 & 210 & 250 & 290 & 340 \\
\hline 74 & Delaware River below Perry Dam, Kans. & 29 & -- & 150 & 180 & 200 & -- \\
\hline 83 & Wakarusa River near Lawrence, Kans. & 28 & -- & 150 & 180 & 210 & -- \\
\hline 88 & Kansas River at DeSoto, Kans. & 34 & 130 & 150 & 200 & 230 & 270 \\
\hline \multicolumn{8}{|c|}{ Carbonate } \\
\hline 1 & Kansas River at Fort Riley, Kans. & 29 & -- & 0 & 7.0 & 20 & -- \\
\hline 3 & Kings Creek near Manhattan, Kans. & 21 & -- & 0 & 0 & 0 & -- \\
\hline 23 & West Fork Big Blue River near Dorchester, Nebr. & 34 & 0 & 0 & 0 & 0 & 6.0 \\
\hline 35 & Big Blue River at Barneston, Nebr. & 36 & 0 & 0 & 0 . & 13 & 20 \\
\hline 47 & Little Blue River at Hollenberg, Kans. & 36 & 0 & 0 & 0 & 3.5 & 12 \\
\hline 50 & Black Vermillion River near Frankfort, Kans. & 34 & 0 & 0 & 0 & 0 & 32 \\
\hline 52 & Big Blue River near Manhattan, Kans. & 35 & 0 & 0 & 7.0 & 22 & 33 \\
\hline 59 & Mill Creek near Paxico, Kans. & 31 & 0 & 0 & 0 & 12 & 33 \\
\hline 62 & Kansas River at Topeka, Kans. & 31 & 0 & 0 & 18 & 24 & 36 \\
\hline 72 & Delaware River near Muscotah, Kans. & 29 & -- & 0 & 0 & 24 & -- \\
\hline 74 & Delaware River below Perry Dam, Kans. & 28 & -- & 0 & 0 & 16 & -- \\
\hline 83 & Wakarusa River near Lawrence, Kans. & 27 & -- & 0 & 0 & 1.0 & -. \\
\hline 88 & Kansas River at DeSoto, Kans. & 30 & 0 & 0 & 12 & 31 & 38 \\
\hline \multicolumn{8}{|c|}{ Sulfate, dissolved } \\
\hline 1 & Kansas River at Fort Riley, Kans. & 39 & 71 & 160 & 190 & 230 & 260 \\
\hline 3 & Kings Creek near Manhattan, Kans. & 24 & -- & 22 & 34 & 40 & -- \\
\hline 23 & West Fork Big Blue River near Dorchester, Nebr. & 44 & 12 & 47 & 54 & 61 & 66 \\
\hline 35 & Big Blue River at Barneston, Nebr. & 41 & 27 & 52 & 68 & 78 & 85 \\
\hline 47 & Little Blue River at Hollenberg, Kans. & 40 & 18 & 33 & 38 & 44 & 48 \\
\hline
\end{tabular}


Table 5. Statistical summary of data for dissolved solids and major ions in water from fixed stations in lower Kansas River Basin, Kansas and Nebraska, May 1987-April 1990-Continued

\begin{tabular}{|c|c|c|c|c|c|c|c|}
\hline \multirow{2}{*}{$\begin{array}{c}\text { Station } \\
\text { number } \\
\text { (fig. 9) }\end{array}$} & \multirow[b]{2}{*}{ Station name } & \multirow{2}{*}{$\begin{array}{c}\text { Number } \\
\text { of } \\
\text { analyses }\end{array}$} & \multicolumn{5}{|c|}{ Value at indicated percentile } \\
\hline & & & 10 & 25 & $\begin{array}{l}50 \text { (me- } \\
\text { dlan) }\end{array}$ & 75 & 90 \\
\hline \multicolumn{8}{|c|}{ Sulfate, dissolved_-Continued } \\
\hline 50 & Black Vermillion River near Frankfort, Kans. & 43 & 21 & 31 & 42 & 50 & 57 \\
\hline 52 & Big Blue River near Manhattan, Kans. & 36 & 32 & 41 & 64 & 68 & 72 \\
\hline 59 & Mill Creek near Paxico, Kans. & 40 & 45 & 60 & 94 & 130 & 140 \\
\hline 62 & Kansas River at Topeka, Kans & 38 & 64 & 86 & 120 & 140 & 160 \\
\hline 72 . & Delaware River near Muscotah, Kans. & 38 & 40 & 58 & 86 & 130 & 180 \\
\hline 74 & Delaware River below Perry Dam, Kans. & 34 & 24 & 26 & 30 & 32 & 35 \\
\hline 83 & Wakarusa River near Lawrence, Kans. & 35 & 30 & 31 & 34 & 37 & 38 \\
\hline 88 & Kansas River at DeSoto, Kans. & 38 & 55 & 90 & 120 & 150 & 160 \\
\hline \multicolumn{8}{|c|}{ Chloride, dissolved } \\
\hline 1 & Kansas River at Fort Riley, Kans. & 37 & 69 & 140 & 210 & 320 & 360 \\
\hline 3 & Kings Creek near Manhattan, Kans. & 24 & -- & 1.0 & 1.6 & 1.9 & -- \\
\hline 23 & West Fork Big Blue River near Dorchester, Nebr. & 43 & 4.8 & 13 & 17 & 21 & 23 \\
\hline 35 & Big Blue River at Barneston, Nebr. & 41 & 8.9 & 22 & 37 & 46 & 53 \\
\hline 47 & Little Blue River at Hollenberg, Kans. & 40 & 7.7 & 24 & 36 & 41 & 52 \\
\hline 50 & Black Vermillion River near Frankfort, Kans. & 43 & 4.3 & 9.1 & 10 & 11 & 13 \\
\hline 52 & Big Blue River near Manhattan, Kans. & 37 & 10 & 16 & 21 & 26 & 31 \\
\hline 59 & Mill Creek near Paxico, Kans. & 40 & 7.0 & 8.6 & 14 & 18 & 24 \\
\hline 62 & Kansas River at Topeka, Kans. & 38 & 44 & 80 & 100 & 150 & 180 \\
\hline 72 & Delaware River near Muscotah, Kans. & 38 & 7.9 & 13 & 17 & 24 & 29 \\
\hline 74 & Delaware River below Perry Dam, Kans. & 34 & 5.4 & 7.4 & 7.9 & 9.2 & 9.6 \\
\hline 83 & Wakarusa River near Lawrence, Kans. & 35 & 4.5 & 5.8 & 7.3 & 11 & 17 \\
\hline 88 & Kansas River at DeSoto, Kans. & 39 & 25 & 70 & 94 & 130 & 140 \\
\hline \multicolumn{8}{|c|}{ Fluoride, dissolved } \\
\hline 23 & West Fork Big Blue River near Dorchester, Nebr. & 27 & -- & .3 & .3 & 3 & -- \\
\hline 35 & Big Blue River at Barneston, Nebr. & 31 & .2 & .3 & .3 & .3 & .4 \\
\hline 47 & Little Blue River at Hollenberg, Kans. & 24 & -- & .3 & .3 & .3 & - \\
\hline 59 & Mill Creek near Paxico, Kans. & 10 & -- & .2 & .2 & .3 & -- \\
\hline 62 & Kansas River at Topeka, Kans. & 10 & -- & .3 & .3 & .4 & -- \\
\hline 72 & Delaware River near Muscotah, Kans. & 36 & .2 & .2 & .3 & .3 & .4 \\
\hline 74 & Delaware River below Perry Dam, Kans. & 34 & .2 & .3 & .3 & .3 & .4 \\
\hline 83 & Wakarusa River near Lawrence, Kans. & 35 & .2 & .2 & .3 & .3 & .3 \\
\hline
\end{tabular}


Table 5. Statistical summary of data for dissolved solids and major ions in water from fixed stations in lower Kansas River Basin, Kansas and Nebraska, May 1987-April 1990-Continued

\begin{tabular}{|c|c|c|c|c|c|c|c|}
\hline \multirow[b]{2}{*}{$\begin{array}{c}\text { Station } \\
\text { number } \\
\text { (fig. 9) }\end{array}$} & \multirow[b]{2}{*}{ Station name } & \multirow[b]{2}{*}{$\begin{array}{c}\text { Number } \\
\text { of } \\
\text { analyses }\end{array}$} & \multicolumn{5}{|c|}{ Value at indicated percentile } \\
\hline & & & 10 & 25 & $\begin{array}{c}50 \text { (me- } \\
\text { dian) }\end{array}$ & 75 & 90 \\
\hline \multicolumn{8}{|c|}{ Sillica, dissolved } \\
\hline 1 & Kansas River at Fort Riley, Kans. & 39 & 3.4 & 6.1 & 8.3 & 11 & 12 \\
\hline 3 & Kings Creek near Manhattan, Kans. & 24 & -- & 12 & 14 & 15 & -- \\
\hline 23 & West Fork Big Blue River near Dorchester, Nebr. & 44 & 12 & 23 & 27 & 29 & 31 \\
\hline 35 & Big Blue River at Barneston, Nebr. & 41 & 10 & 14 & 19 & 22 & 24 \\
\hline 47 & Little Blue River at Hollenberg, Kans. & 40 & 12 & 18 & 22 & 25 & 28 \\
\hline 50 & Black Vermillion River near Frankfort, Kans. & 42 & 8.0 & 12 & 15 & 17 & 19 \\
\hline 52 & Big Blue River near Manhattan, Kans. & 37 & 4.1 & 6.6 & 10 & 13 & 15 \\
\hline 59 & Mill Creek near Paxico, Kans. & 40 & 6.6 & 8.9 & 11 & 12 & 15 \\
\hline 62 & Kansas River at Topeka, Kans. & 37 & 2.1 & 4.4 & 7.6 & 11 & 12 \\
\hline 72 & Delaware River near Muscotah, Kans. & 38 & 2.8 & 5.4 & 7.7 & 9.4 & 11 \\
\hline 74 & Delaware River below Perry Dam, Kans. & 34 & .1 & .3 & 1.9 & 5.3 & 6.5 \\
\hline 83 & Wakarusa River near Lawrence, Kans. & 35 & .1 & .7 & 1.5 & 3.0 & 4.5 \\
\hline 88 & Kansas River at DeSoto, Kans. & 39 & .4 & 2.6 & 6.7 & 11 & 12 \\
\hline
\end{tabular}

the fixed stations had total hardness exceeding $120 \mathrm{mg} / \mathrm{L}$ as $\mathrm{CaCO}_{3}$ and thus were "hard" or "very hard" according to the classification of Durfor and Becker (1964). Noncarbonate hardness, that part which exceeds alkalinity (Hem, 1985), generally was a relatively small part of the total hardness (table 5).

Sodium in drinking water has not been shown to adversely affect the general population. However, limits of $20 \mathrm{mg} / \mathrm{L}$ for persons on very restricted diets and $270 \mathrm{mg} / \mathrm{L}$ for persons on moderately restricted diets have been recommended (U.S. Environmental Protection Agency, 1978). The 50th-percentile (median) concentrations exceeded $20 \mathrm{mg} / \mathrm{L}$ at 9 of the 13 stations, but the 90th-percentile concentration did not exceed $270 \mathrm{mg} / \mathrm{L}$ at any station.

The dominance of water contributed by the Smoky Hill River on the concentrations of major ions in the Kansas River is apparent when comparing median concentrations of selected major ions at the 13 fixed stations (fig. 12). At the main-stem
Kansas River (stations 1, 62, and 88), median sodium concentrations exceed median calcium concentrations. At all other fixed stations, median calcium concentrations exceed median sodium concentrations. Similarly, median concentrations of sulfate plus chloride exceed median concentrations of bicarbonate only in the main stem. These conditions reflect saline ground water discharging from Permian formations upstream of Fort Riley. These formations crop out in the Smoky Hill River Basin (Gillespie and Hargadine, 1981) and contain large quantities of sodium chloride in solution. In contrast, surface water originating within the study unit reflects the relatively greater abundance of calcium carbonate in limestone and loess deposits (Ritter, 1978), which comprise much of the surficial and near-surface geologic units.

With few exceptions, the three ions having the largest concentrations at any particular station are the same at all percentiles, based on the data in table 5 , although the rank of each ion may change. Statistical distributions of dissolved-solids, sodium, and chloride concentrations are similar for 


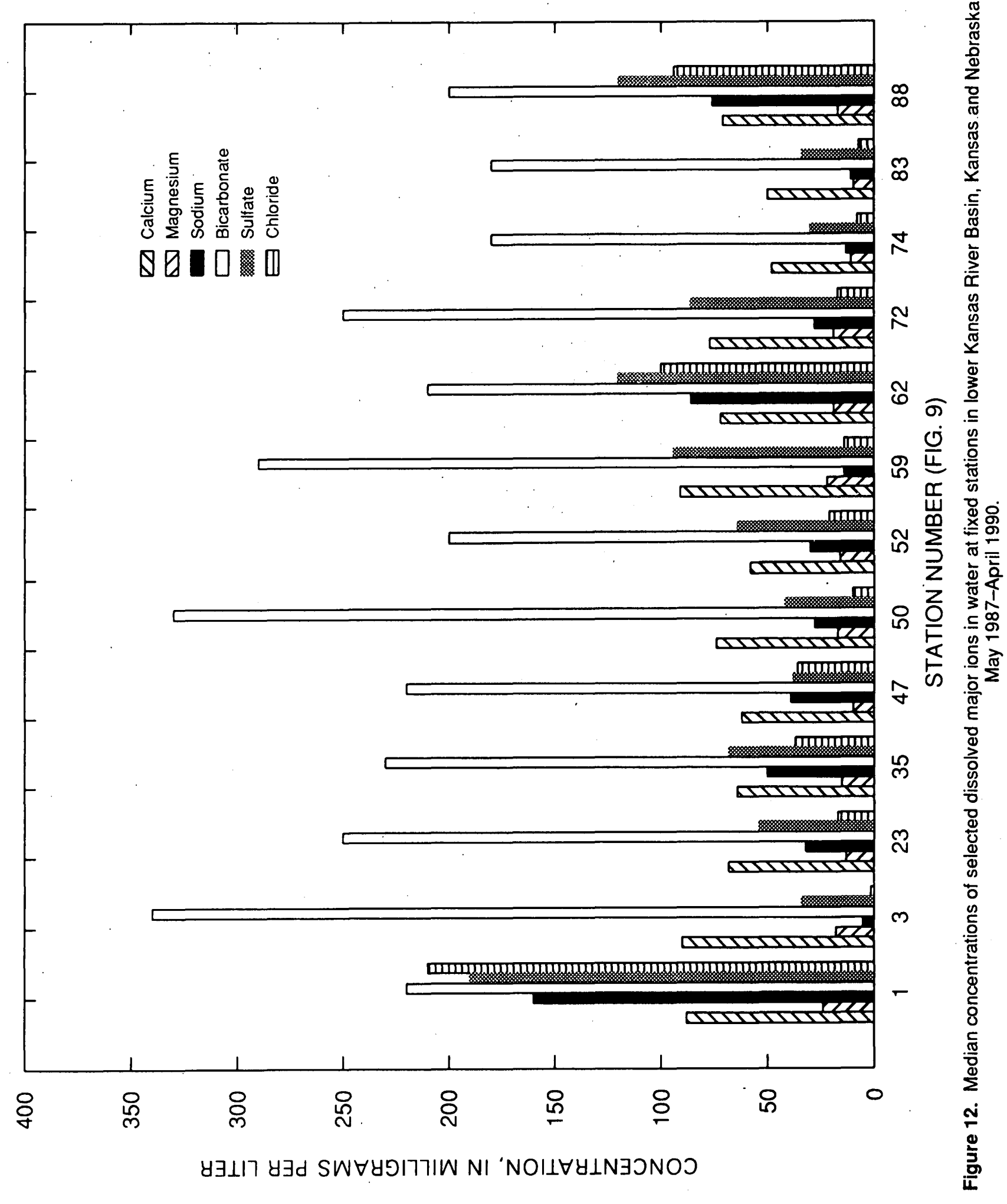


the fixed stations. The statistical distributions of dissolved-chloride concentrations at the fixed stations are shown in figure 13. This figure reflects the contribution of chloride to the main-stem Kansas River from the Smoky Hill River.

Seasonal variations in concentrations of dissolved solids and major ions in streams relate to the relative contributions of surface runoff and ground water. Concentrations tend to be smaller when surface runoff occurs, most frequently during the spring and summer. However, on the mainstem Kansas River, seasonal variations are obscured by releases from reservoirs and from differences in water quality of tributaries.

Bromide, fluoride, and silica alsò are discussed although they are not major constituents in the surface water of the study unit. Bromide is the ionic form of the nonmetallic element bromine. Bromide may occur naturally in brines and geothermal water and is used in some commercial and industrial products (Hem, 1985). Analyses of samples from the 13 fixed stations during 1987-90 indicated uniformly small concentrations, the maximum being $0.2 \mathrm{mg} / \mathrm{L}$. Concentrations did not show any systematic areal or seasonal variations.

Fluoride, the ionic form of the element fluorine, is used by more complex life forms in the structure of bones and teeth (Hem, 1985).

Concentrations in natural water generally are less than $1.0 \mathrm{mg} / \mathrm{L}$. In the study unit, 10 th- and 90 thpercentile concentrations ranged from 0.2 $0.4 \mathrm{mg} / \mathrm{L}$ for the $1987-90$ sampling period (table $5)$, the same as the range for 1978-86 reported by Jordan (1991d). The maximum concentration was $0.5 \mathrm{mg} / \mathrm{L}$, substantially less than the drinking-water MCL of $4.0 \mathrm{mg} / \mathrm{L}$ (U.S. Environmental Protection Agency, 1987).

Silica is the oxide of the element silicon, which is the second most abundant element in the Earth's crust. It occurs in water in hydrated form and probably originates mostly from the breakdown of silicate minerals (Hem, 1985). Concentrations in streams in the study unit are consistent with typical concentrations of 1 to $30 \mathrm{mg} / \mathrm{L}$ in natural water, as discussed by Hem (1985). A statistical summary of dissolved-silica concentrations during the 198790 sampling period (table 5) indicates values and distributions similar to those shown by Jordan (1991d) for 1978-86 data. Largest concentrations occurred in the Blue River drainage area, which probably reflects the large ground-water component in streamflow in that area; the relatively slow movement of ground water allows time for dissolution of rock and mineral material with which it is in contact.

\section{Transport Rates}

Transport rates for dissolved solids, sodium, and chloride are given in table 6 for selected fixed stations on and major tributaries to the Kansas River. Table 6 also lists root-mean-square error and percentage of transport rate calculated from streamflow values larger than those used to establish the relation between transport rate and streamflow. Larger values of either indicate relatively greater uncertainty in the transport results.

The contribution of dissolved solids and major ions to the Kansas River by the Smoky Hill and Republican River systems is evident when comparing transport rates at Fort Riley (station 1) to DeSoto (station 88) for 1987-90. The dissolvedsolids transport rate at Fort Riley accounted for 58 percent of the transport rate at DeSoto. Similarly, chloride transport rate at Fort Riley accounted for 87 percent of the transport rate at DeSoto, even though only about 36 percent of the streamflow at DeSoto was present at Fort Riley. Conversely, the Big Blue River contributed about 36 percent of the streamflow at DeSoto, but only about 25 percent of the dissolved solids.

Transport rates were computed by Jordan (1991d) for dissolved solids, sodium, and chloride for 1978-86. Comparison of transport rates in the stations common to both periods shows smaller rates of dissolved-solids transport in the Big Blue River near Manhattan, Kans. (station 52), and the Kansas River at DeSoto, Kans. (station 88), during 1987-90 than during 1978-86. Dissolved-solids transport rates during 1987-90 were approximately 70 percent of the rates for the earlier period at those stations. These smaller transport rates are attributed mainly to smaller streamflow; slightly greater than average streamflow occurred in 197886 (Jordan, 1991c), but considerably less than average streamflow characterized 1987-90 (table 2). Differences in sodium and chloride transport rates between the same periods at these stations were smaller because the principal source of these constituents is ground water (base flow) from 

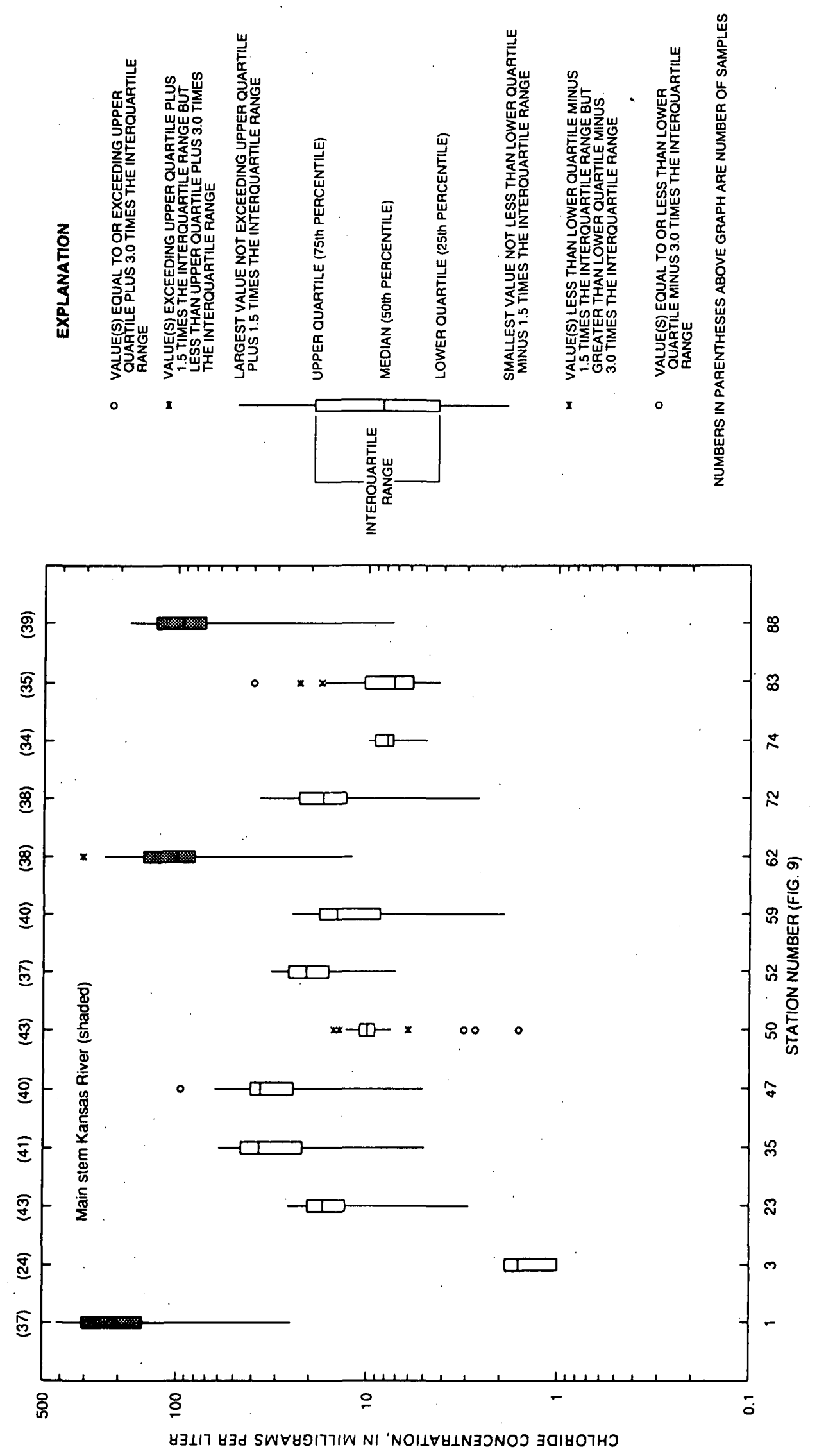

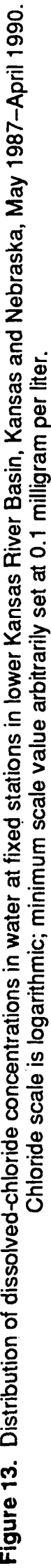


Table 6. Transport rates of dissolved solids, sodium, and chloride at selected fixed stations in lower Kansas River Basin, Kansas and Nebraska, May 1987-April 1990

\begin{tabular}{|c|c|c|c|c|}
\hline $\begin{array}{l}\text { Station } \\
\text { number } \\
\text { (fig. 9) }\end{array}$ & Station name & $\begin{array}{l}\text { Mean annual } \\
\text { transport rate } \\
\text { (tons per year) }\end{array}$ & $\begin{array}{l}\text { Root-mean- } \\
\text { square error of } \\
\text { mean annual } \\
\text { transport rate } \\
\text { (percent) }\end{array}$ & $\begin{array}{l}\text { Percentage of } \\
\text { transport rate } \\
\text { based on } \\
\text { extrapolation } 1\end{array}$ \\
\hline \multicolumn{5}{|c|}{ Dissolved solids } \\
\hline 1 & Kansas River at Fort Riley, Kans. & $1,100,000$ & 5 & 3 \\
\hline 52 & Big Blue River near Manhattan, Kans. & 480,000 & 5 & 15 \\
\hline 59 & Mill Creek near Paxico, Kans. & 20,000 & 5 & 4 \\
\hline 62 & Kansas River at Topeka, Kans. & $1,700,000$ & 4 & 5 \\
\hline 74 & Delaware River below Perry Dam, Kans. & 55,000 & 4 & 40 \\
\hline 83 & Wakarusa River near Lawrence, Kans. & 20,000 & 5 & 29 \\
\hline 88 & Kansas River at DeSoto, Kans. & $1,900,000$ & 3 & 14 \\
\hline \multicolumn{5}{|c|}{ Sodium } \\
\hline 1 & Kansas River at Fort Riley, Kans. & 190,000 & 8 & 3 \\
\hline 52 & Big Blue River near Manhattan, Kans. & 43,000 & 9 & 14 \\
\hline 59 & Mill Creek near Paxico, Kans. & 600 & 5 & 3 \\
\hline 62 & Kansas River at Topeka, Kans. & 240,000 & 6 & 3 \\
\hline 74 & Delaware River below Perry Dam, Kans. & 2,900 & 6 & 30 \\
\hline 83 & Wakarusa River near Lawrence, Kans. & 990 & 7 & 25 \\
\hline 88 & Kansas River at DeSoto, Kans. & 260,000 & 4 & 9 \\
\hline \multicolumn{5}{|c|}{ Chloride } \\
\hline 1 & Kansas River at Fort Riley, Kans. & 270,000 & 9 & 3 \\
\hline 52 & Big Blue River near Manhattan, Kans. & 31,000 & 9 & 14 \\
\hline 59 & Mill Creek near Paxico, Kans. & 520 & 5 & 3 \\
\hline 62 & Kansas River at Topeka, Kans. & 290,000 & 7 & 2 \\
\hline 74 & Delaware River below Perry Dam, Kans. & 1,700 & 6 & 30 \\
\hline 83 & Wakarusa River near Lawrence, Kans. & 660 & 14 & 24 \\
\hline 88 & Kansas Riverat DeSoto, Kans. & 310,000 & 5 & 9 \\
\hline
\end{tabular}

${ }^{1}$ Percentage of transport rate calculated from streamflow values larger than those used to establish the relation between transport rate and streamflow.

Permian formations underlying the Smoky Hill River Basin; the base-flow component of streamflow does not vary as much as the surface-runoff component.

\section{Trends}

Trend-test results for dissolved solids, total hardness, and selected major ions are presented in table 7 for fixed stations that had adequate data. For each constituent, data are shown for a period common to a group of stations and for the longest available period at each station. Results shown in the common period represent the longest period common to the most fixed stations for individual constituents. Because the period for trend analysis may vary among constituents at the same station or 
Table 7. Trend-test results for dissolved solids and selected major ions in water from selected fixed stations in lower Kansas River Basin, Kansas and Nebraska

[Underlined $($ ), significant at 0.1 probability level; <, less than; results are flow-adjusted except for stations 52 and 74 where flow was regulated directly by reservoir operation; calculated rate of change is percent of median per year]

\begin{tabular}{|c|c|c|c|c|c|}
\hline \multirow[b]{2}{*}{$\begin{array}{l}\text { Station } \\
\text { number } \\
\text { (fig. 9) }\end{array}$} & \multirow[b]{2}{*}{ Station name } & \multirow[b]{2}{*}{$\begin{array}{c}\text { Inclusive } \\
\text { years }\end{array}$} & \multirow[b]{2}{*}{$\begin{array}{l}\text { Number } \\
\text { of years }\end{array}$} & \multicolumn{2}{|c|}{$\begin{array}{l}\text { Results of seasonal } \\
\text { Kendail tests for time } \\
\text { trend }\end{array}$} \\
\hline & & & & $\begin{array}{l}\text { Prob- } \\
\text { ability } \\
\text { level }\end{array}$ & $\begin{array}{l}\text { Calculated } \\
\text { rate of } \\
\text { change of } \\
\text { concen- } \\
\text { tration } \\
\text { (percent per } \\
\text { year) }\end{array}$ \\
\hline \multicolumn{6}{|c|}{ Dissolved solids } \\
\hline \multicolumn{6}{|c|}{ Common period } \\
\hline 47 & Little Blue River at Hollenberg, Kans. & $1973-90$ & 18 & 0.20 & -0.44 \\
\hline 52 & Big Blue River near Manhattan, Kans. & 1973-90 & 18 & .57 & -.21 \\
\hline 74 & Delaware River below Perry Dam, Kans. & $1973-90$ & 18 & .84 & .12 \\
\hline 88 & Kansas River at DeSoto, Kans. & $1973-90$ & 18 & .37 & -.56 \\
\hline \multicolumn{6}{|c|}{ Longest available period } \\
\hline 3 & Kings Creek near Manhattan, Kans. & $1980-90$ & 11 & .70 & .25 \\
\hline 23 & West Fork Big Blue River near Dorchester, Nebr. & $1963-90$ & 28 & .14 & .35 \\
\hline 52 & Big Blue River near Manhattan, Kans. & $1963-90$ & 28 & $<.005$ & .76 \\
\hline \multicolumn{6}{|c|}{ Total hardness } \\
\hline \multicolumn{6}{|c|}{ Common period. } \\
\hline 23 & West Fork Big Blue River near Dorchester, Nebr. & $1973-90$ & 18 & $<.005$ & 1,4 \\
\hline 47 & Little Blue River at Hollenberg, Kans. & $1973-90$ & 18 & .18 & 1.0 \\
\hline 52 & Big Blue River near Manhattan, Kans. & $1973-90$ & 18 & .98 & 0 \\
\hline 74 & Delaware River below Perry Dam, Kans. & $1973-90$ & 18 & .76 & -.39 \\
\hline 88 & Kansas River at DeSoto, Kans. & $1973-90$ & 18 & .18 & -.57 \\
\hline \multicolumn{6}{|c|}{ Longest available period } \\
\hline 3 & Kings Creek near Manhattan, Kans. & $1980-90$ & 11 & .12 & .82 \\
\hline 23 & West Fork Big Blue River near Dorchester, Nebr. & $1963-90$ & 28 & $<.005$ & 84 \\
\hline 35 & Big Blue River at Barneston, Nebr. & $1980-90$ & 11 & 1.00 & .02 \\
\hline 52 & Big Blue River near Manhattan, Kans. & $1963-90$ & 28 & .01 & .72 \\
\hline 62 & Kansas River at Topeka, Kans. & $1953-90$ & 38 & .20 & .39 \\
\hline 74 & Delaware River below Perry Dam, Kans. & $1970-90$ & 21 & .05 &. .65 \\
\hline
\end{tabular}


Table 7. Trend-test results for dissolved solids and selected major ions in water from selected fixed stations in lower Kansas River Basin, Kansas and Nebraska-Continued

\begin{tabular}{|c|c|c|c|c|c|}
\hline \multirow[b]{2}{*}{$\begin{array}{l}\text { Station } \\
\text { number } \\
\text { (fig. 9) }\end{array}$} & \multirow[b]{2}{*}{ Station name } & \multirow[b]{2}{*}{$\begin{array}{c}\text { Inclusive } \\
\text { years }\end{array}$} & \multirow[b]{2}{*}{$\begin{array}{l}\text { Number } \\
\text { of years }\end{array}$} & \multicolumn{2}{|c|}{$\begin{array}{l}\text { Results of seasonal } \\
\text { Kendall tests for time } \\
\text { trend }\end{array}$} \\
\hline & & & & $\begin{array}{l}\text { Prob- } \\
\text { ablilty } \\
\text { level }\end{array}$ & $\begin{array}{l}\text { Calculated } \\
\text { rate of } \\
\text { change of } \\
\text { concen- } \\
\text { tration } \\
\text { (percent per } \\
\text { year) }\end{array}$ \\
\hline \multicolumn{6}{|c|}{ Calcium } \\
\hline \multicolumn{6}{|c|}{ Common period } \\
\hline 23 & West Fork Big Blue River near Dorchester, Nebr. & $1973-90$ & 18 & $<\underline{0.005}$ & 1.2 \\
\hline 47 & Little Blue River at Hollenberg, Kans. & $1973-90$ & 18 & .23 & .92 \\
\hline 52 & Big Blue River near Manhattan, Kans. & $1973-90$ & 18 & .64 & -.23 \\
\hline 74 & Delaware River below Perry Dam, Kans. & $1973-90$ & 18 & .32 & -.23 \\
\hline 88 & Kansas River at DeSoto, Kans. & 1973-90 & 18 & .10 &.- .24 \\
\hline \multicolumn{6}{|c|}{ Longest a vailable period } \\
\hline 3 & Kings Creek near Manhattan, Kans. & $1980-90$ & 11 & .06 & .63 \\
\hline 23 & West Fork Big Blue River near Dorchester, Nebr. & $1963-90$ & 28 & $<, 005$ & 24 \\
\hline 35 & Big Blue River at Barneston, Nebr. & $1966-90$ & 25 & .24 & .53 \\
\hline 52 & Big Blue River near Manhattan, Kans. & $1963-90$ & 28 & .08 & .52 \\
\hline 74 & Delaware River below Perry Dam, Kans. & 1970-90 & 21 & 01 &. .67 \\
\hline \multicolumn{6}{|c|}{ Magnesium } \\
\hline \multicolumn{6}{|c|}{ Common period } \\
\hline 23 & West Fork Big Blue River near Dorchester, Nebr. & $1973-90$ & 18 & $<, 005$ & 1.2 \\
\hline 47 & Little Blue River at Hollenberg, Kans. & $1973-90$ & 18 & 10 & $\underline{1,1}$ \\
\hline 52 & Big Blue River near Manhattan, Kans. & $1973-90$ & 18 & .82 & 0 \\
\hline 74 & Delaware River below Perry Dam, Kans. & $1973-90$ & 18 & .11 & .90 \\
\hline 88 & Kansas River at DeSoto, Kans. & $1973-90$ & 18 & .47 & -.37 \\
\hline \multicolumn{6}{|c|}{ Longest avallable period } \\
\hline 3 & Kings Creek near Manhattan, Kans. & 1980-90 & 11 & .15 & .76 \\
\hline 23 & West Fork Big Blue River near Dorchester, Nebr. & $1963-90$ & 28 & $<.005$ & .72 \\
\hline 35 & Big Blue River at Barneston, Nebr. & $1966-90$ & 25 & .57 & .48 \\
\hline 52 & Big Blue River near Manhattan, Kans. & $1963-90$ & 28 & $<.005$ & 1.2 \\
\hline 74 & Delaware River below Perry Dam, Kans. & $1970-90$ & 21 & .95 & 0 \\
\hline
\end{tabular}


Table 7. Trend-test results for dissolved solids and selected major ions in water from selected fixed stations in lower Kansas River Basin, Kansas and Nebraska-Continued

\begin{tabular}{|c|c|c|c|c|c|}
\hline \multirow[b]{2}{*}{$\begin{array}{c}\text { Statlon } \\
\text { number } \\
\text { (fig. 9) }\end{array}$} & \multirow[b]{2}{*}{ Station name } & \multirow[b]{2}{*}{$\begin{array}{c}\text { Inclusive } \\
\text { years }\end{array}$} & \multirow[b]{2}{*}{$\begin{array}{l}\text { Number } \\
\text { of years }\end{array}$} & \multicolumn{2}{|c|}{$\begin{array}{l}\text { Results of seasonal } \\
\text { Kendall tests for time } \\
\text { trend }\end{array}$} \\
\hline & & & & $\begin{array}{l}\text { Prob- } \\
\text { ability } \\
\text { lovel }\end{array}$ & $\begin{array}{l}\text { Calculated } \\
\text { rate of } \\
\text { change of } \\
\text { concen- } \\
\text { tration } \\
\text { (percent per } \\
\text { year) }\end{array}$ \\
\hline \multicolumn{6}{|c|}{ Sodium } \\
\hline \multicolumn{6}{|c|}{ Common period } \\
\hline 23 & West Fork Big Blue River near Dorchester, Nebr. & $1973-90$ & 18 & 0.23 & 0.72 \\
\hline 47 & Little Blue River at Hollenberg, Kans. & $1973-90$ & 18 & .55 & .60 \\
\hline 52 & Big Blue River near Manhattan, Kans. & $1973-90$ & 18 & .09 & 1.6 \\
\hline 74 & Delaware River below Perry Dam, Kans. & $1973-90$ & 18 & $<.005$ & $\underline{2.9}$ \\
\hline 88 & Kansas River at DeSoto, Kans. & $1973-90$ & 18 & .88 & -.17 \\
\hline \multicolumn{6}{|c|}{ Longest available period } \\
\hline 3 & Kings Creek near Manhattan, Kans. & $1980-90$ & 11 & .73 & .17 \\
\hline 23 & West Fork Big Blue River near Dorchester, Nebr. & $1963-90$ & 28 & .01 & 66 \\
\hline 35 & Big Blue River at Barneston, Nebr. & $1966-90$ & 25 & .44 & .44 \\
\hline 52 & Big Blue River near Manhattan, Kans. & $1963-90$ & 28 & .01 & $\underline{1.3}$ \\
\hline 74 & Delaware River below Perry Dam, Kans. & $1970-90$ & 21 & .31 & 1.1 \\
\hline \multicolumn{6}{|c|}{ Potassium } \\
\hline \multicolumn{6}{|c|}{ Common period } \\
\hline 23 & West Fork Big Blue River near Dorchester, Nebr. & $1973-90$ & 18 & .96 & -.03 \\
\hline 47 & Little Blue River at Hollenberg, Kans. & $1973-90$ & 18 & .74 & -.23 \\
\hline 52 & Big Blue River near Manhattan, Kans. & $1973-90$ & 18 & .85 & 0 \\
\hline 74 & Delaware River below Perry Dam, Kans. & $1973-90$ & 18 & .16 & .43 \\
\hline 88 & Kansas River at DeSoto, Kans. & $1973-90$ & 18 & .21 & .55 \\
\hline \multicolumn{6}{|c|}{ Longest available period } \\
\hline 3 & Kings Creek near Manhattan, Kans. & $1980-90$ & 11 & .12 & -1.4 \\
\hline 23 & West Fork Big Blue River near Dorchester, Nebr. & $1963-90$ & 28 & .09 & 42 \\
\hline 35 & Big Blue River at Barneston, Nebr. & $1966-90$ & 25 & .24 & -.35 \\
\hline 52 & Big Blue River near Manhattan, Kans. & 1963-90 & 28 & .01 & -35 \\
\hline 74 & Delaware River below Perry Dam, Kans. & 1970-90 & 21 & .34 & -.34 \\
\hline
\end{tabular}


Table 7. Trend-test results for dissolved solids and selected major ions in water from selected fixed stations in lower Kansas River Basin, Kansas and Nebraska-Continued

\begin{tabular}{|c|c|c|c|c|c|}
\hline \multirow[b]{2}{*}{$\begin{array}{c}\text { Station } \\
\text { number } \\
\text { (fig. 9) }\end{array}$} & \multirow[b]{2}{*}{ Station name } & \multirow[b]{2}{*}{$\begin{array}{c}\text { Inclusive } \\
\text { years }\end{array}$} & \multirow[b]{2}{*}{$\begin{array}{l}\text { Number } \\
\text { of years }\end{array}$} & \multicolumn{2}{|c|}{$\begin{array}{l}\text { Results of seasonal } \\
\text { Kendall tests for time } \\
\text { trend }\end{array}$} \\
\hline & & & & $\begin{array}{l}\text { Prob- } \\
\text { ability } \\
\text { level }\end{array}$ & $\begin{array}{l}\text { Calculated } \\
\text { rate of } \\
\text { change of } \\
\text { concen- } \\
\text { tration } \\
\text { (percent per } \\
\text { year) }\end{array}$ \\
\hline \multicolumn{6}{|c|}{ Sulfate } \\
\hline \multicolumn{6}{|c|}{ Common period } \\
\hline 23 & West Fork Big Blue River near Dorchester, Nebr. & $1973-90$ & 18 & $\underline{0.01}$ & $\underline{1.5}$. \\
\hline 47 & Little Blue River at Hollenberg, Kans. & $1973-90$ & 18 & .65 & -.35 \\
\hline 52 & Big Blue River near Manhattan, Kans. & $1973-90$ & 18 & .88 & 0 \\
\hline 74 & Delaware River below Perry Dam, Kans. & $1973-90$ & 18 & .05 & $\underline{1,1}$ \\
\hline 88 & Kansas River at DeSoto, Kans. & $1973-90$ & 18 & .91 & -.05 \\
\hline \multicolumn{6}{|c|}{ Longest a vailable period } \\
\hline 3 & Kings Creek near Manhattan, Kans. & $1980-90$ & 11 & .27 & -2.1 \\
\hline 23 & West Fork Big Blue River near Dorchester, Nebr. & $1963-90$ & 28 & $<.005$ & 1.5 \\
\hline 35 & Big Blue River at Barneston, Nebr. & $1966-90$ & 25 & .44 & .67 \\
\hline 52 & Big Blue River near Manhattan, Kans. & $1963-90$ & 28 & .005 & $\underline{1.8}$ \\
\hline 74 & Delaware River below Perry Dam, Kans. & $1970-90$ & 21 & .37 & -.23 \\
\hline \multicolumn{6}{|c|}{ Chloride } \\
\hline \multicolumn{6}{|c|}{ Common period } \\
\hline 23 & West Fork Big Blue River near Dorchester, Nebr. & $1973-90$ & 18 & .75 & -.24 \\
\hline 47 & Little Blue River at Hollenberg, Kans. & $1973-90$ & 18 & .10 & $-\underline{-1.0}$ \\
\hline 52 & Big Blue River near Manhattan, Kans. & $1973-90$ & 18 & .70 & -.14 \\
\hline 74 & Delaware River below Perry Dam, Kans. & $1973-90$ & 18 & .23 & 1.5 \\
\hline 88 & Kansas River at DeSoto, Kans. & $1973-90$ & 18 & .55 & -.76 \\
\hline \multicolumn{6}{|c|}{ Longest available period } \\
\hline 3 & Kings Creek near Manhattan, Kans. & 1980-90 & 11 & .30 & -1.4 \\
\hline 23 & West Fork Big Blue River near Dorchester, Nebr. & $1963-90$ & 28 & .06 & .55 \\
\hline 35 & Big Blue River at Barneston, Nebr. & $1966-90$ & 25 & .97 & .08 \\
\hline 52 & Big Blue River near Manhattan, Kans. & $1963-90$ & 28 & .99 & 0 \\
\hline 74 & Delaware River below Perry Dam, Kans. & $1970-90$ & 21 & .06 & -.84 \\
\hline
\end{tabular}


from one station to another, the resulting trends may be different. For example, the Big Blue River near Manhattan, Kans. (station 52), had a statistically significant upward trend in calcium concentration for the longest period of record available but a downward change without statistical significance for the shorter common period. Thus, caution should be used when comparing trends computed from different periods and different stations. Trend computations were flow-adjusted (Jordan, 1991a) except for the Big Blue River near Manhattan, Kans., and the Delaware River below Perry Dam, Kans. (stations 52 and 74), because these stations are located just downstream from reservoirs with little drainage area between the reservoir outlet and the sampling station.

Statistically significant upward trends in the concentrations of several dissolved major ions were observed in the Big Blue River subbasin. For example, the West Fork Big Blue River near Dorchester, Nebr. (station 23), had significant upward trends in total hardness, calcium, magnesium, sodium, potassium, and sulfate during the longest available period (table 7). These increases in dissolved major-ion concentrations may be attributed to return flow associated with a severalfold increase in irrigated acreage in the upper Big Blue River Basin since 1950 (Jordan, 1991d). Statistically significant upward trends in major ions also were determined for the Big Blue River near Manhattan, Kans. (station 52), probably indicating that the effects of irrigation on major-ion concentrations were strong enough to be evident even at the outflow of Tuttle Creek Lake.

Trend-test results for the Little Blue River at Hollenberg, Kans. (station 47) showed a statistically significant upward trend for magnesium and significant downward trend for chloride (table 7). The Little Blue River subbasin has had a smaller increase in irrigated acreage than the Big Blue River subbasin. However, interpretive comparisons between subbasins may be difficult. Reid and Wood (1976, p. 247) note that "seasonal variation in rainfall and surface runoff, and the geochemical nature of the drainage basin strongly influence the composition of waters in small streams, thereby imparting considerable individuality to streams even within a restricted region."

Jordan (1991d) computed trends for dissolved solids, total hardness, and major ions at many of the fixed stations, for periods that ended in 1986 instead of 1990. A comparison of trends for the two periods show similar results. In general, trends have about the same rate and direction of change. The probability levels may be more or less significant from one study to another, but no consistent pattern is discernible.

\section{Suspended Sediment by P.R. Jordan}

Sediment can cause problems in streams and reservoirs and may indicate problems upstream. For example, suspended sediment needs to be removed from water supplies before treatment. When large quantities of suspended sediment deposit in a stream channel or an inlet of a lake or reservoir, they can raise the water levels of floods. Deposits of sediment in surface-water impoundments can decrease the storage capacity for water supply or flood control and can impair propagation of fish and other aquatic life. In addition to the effects of its physical presence, suspended sediment transports certain nutrients, trace elements, pesticides, and other synthetic organic compounds that have very slight solubility but that attach themselves to sediment particles.

Problems in upstream areas that contribute suspended sediment to streams and reservoirs are related to excessive erosion. Many natural and human factors affect this process. Nearly all soils in the lower Kansas River Basin (fig. 4) are prone to erode and contribute to suspended sediment in streams, especially when other conditions favorable for erosion, such as row-crop tillage, hilly topography, and abundant precipitation, are present (Jordan, 1991e). An important factor in terms of physiography probably is the slight local topographic relief in the High Plains physiographic section (fig. 2), which tends to decrease the rates of erosion that would otherwise occur from those types of surface materials (eolian and fluvial deposits) in that climatic setting. Precipitation variations also are important. A widely used soilloss equation includes a rainfall factor to represent the combined effects of depth and intensity of precipitation (Wischmeier and Smith, 1965). In the study unit, average annual values of the rainfall factor range from 125 to 210 units, and factors for 
individual years vary even more. Also, about 75 percent of the annual precipitation and 90 percent of the annual rainfall factor in the basin normally occurs during the growing season, April through September; thus, erosion and suspendedsediment yields from row croplands are affected greatly by the seasonal patterns of plowing, early growth and later maturity of crops, time of harvest, and presence or absence of crop residues after harvest.

Land use (fig. 5) is a major human factor that affects soil erosion and sediment yield; land used for row crops could be expected to have larger rates of erosion than woodland, rangeland (assuming it was not overgrazed), and other land having continual vegetative cover. Urban and industrial land uses would have large erosion rates only in the parts that have had their vegetative or other cover eliminated during construction activities. Much of the row cropland in the basin has some erosioncontrol treatment, such as terraces and grassed waterways, although lands having such treatments are not differentiated in figure 5. Large surfacewater impoundments typically trap a large part of their sediment inflow; for example, sediment-trap efficiency has been measured accurately for Kanopolis Lake (in Kansas outside the study unit) and was 96 percent from 1948-71 (U.S. Army Corps of Engineers, 1972, table 1). Thousands of small farm ponds and numerous larger detention structures have been constructed within the study unit. These structures typically receive flow from 0.5 to $10 \mathrm{mi}^{2}$ of drainage area, and their sedimenttrap efficiencies probably range from 65 to 90 percent (estimated from relations developed by G.M. Brune and shown by Vanoni, 1975).

Suspended-sediment samples were collected at least monthly from May 1987 through April 1990 at the 13 fixed stations (table 4, fig. 9), except at Kings Creek near Manhattan; this station had no flow at the times of some monthly visits and had a few samples collected at high flow by an automatic sampler. In addition to the monthly scheduled samplings, additional samples were collected under streamflow conditions more typical of longterm normal hydrologic conditions. Additional information on natural and human factors affecting suspended sediment also was obtained.

\section{Concentrations and Particle Size}

A summary of the suspended-sediment concentration and particle-size data collected from May 1987 through April 1990 is presented in table 8. Median suspended-sediment concentrations at the 13 stations ranged from 4 to $110 \mathrm{mg} / \mathrm{L}$, and 90th-percentile concentrations ranged from 58 to $3,200 \mathrm{mg} / \mathrm{L}$ (table 8 ). Some indications of the relations of suspended-sediment concentration to natural and human factors are suggested by the summary data together with other information although the variations of precipitation and runoff from their long-term averages tend to reduce confidence in those indications.

Median suspended-sediment concentrations at the three Kansas River stations (stations 1, 62, and 88) were consistent at 100 to $110 \mathrm{mg} / \mathrm{L}$ (fig. 14) despite the inflow of tributaries with smaller concentrations of suspended sediment, such as the Big Blue River (station 52) and the Delaware River (station 74). Streambed and bank erosion in the Kansas River could account for that condition; however, streambed and bank measurements have not been made to substantiate that possibility.

Large reservoirs immediately upstream from stations on the Big Blue River (station 52), Delaware River (station 74), and Wakarusa River (station 83) undoubtedly accounted for small median concentrations ( 13 to $52 \mathrm{mg} / \mathrm{L}$ ) at those stations and the smallest 90th-percentile concentrations ( 58 to $170 \mathrm{mg} / \mathrm{L}$ ) of all the stations. Other stations having small concentrations included Kings Creek (station 3) and Mill Creek (station 59); the drainage area upstream of the Kings Creek station has no row crops, and the drainage upstream of the Mill Creek station includes little area of row crops.

Stations representing areas of high-density irrigated cropland (fig. 5) in areas of little local relief in the High Plains (fig. 2) (station 23) and medium-density irrigated cropland within more dissected areas (stations 35, 47, and 50) had the largest 90 th-percentile $(1,600$ to $3,200 \mathrm{mg} / \mathrm{L})$ and relatively large median (51 to $110 \mathrm{mg} / \mathrm{L}$ ) concentrations. Station 72 was the exception, having small 90th-percentile and median concentrations although the cropland and relief characteristics are similar to those of station 50 . The small concentrations at station 72 probably resulted from 
Table 8. Statistical summary of data for suspended-sediment concentration and particle size in lower Kansas River Basin, Kansas and Nebraska, May 1987-April 1990

[This table includes only those stations having 10 or more analyses; -- , the 10- and 90 -percentile values are not shown for stations having fewer than 30 analyses]

\begin{tabular}{|c|c|c|c|c|c|c|c|}
\hline \multirow[b]{2}{*}{$\begin{array}{c}\text { Station } \\
\text { number } \\
\text { (flg. 9) }\end{array}$} & \multirow[b]{2}{*}{ Station name } & \multirow[b]{2}{*}{$\begin{array}{c}\text { Number } \\
\text { of } \\
\text { analyses }\end{array}$} & \multicolumn{5}{|c|}{ Value at indicated percentile } \\
\hline & & & 10 & 25 & $\begin{array}{l}50 \text { (me- } \\
\text { dian) }\end{array}$ & 75 & 90 \\
\hline \multicolumn{8}{|c|}{ Suspended-sediment concentration, in milligrams per liter } \\
\hline 1 & Kansas River at Fort Riley, Kans. & 43 & 18 & 49 & 100 & 350 & 930 \\
\hline 3 & Kings Creek near Manhattan, Kans. & 19 & -- & 2 & 4 & 20 & -- \\
\hline 23 & West Fork Big Blue River near Dorchester, Nebr. & 46 & 11 & 41 & 110 & 320 & 1,700 \\
\hline 35 & Big Blue River at Barneston, Nebr. & 43 & 15 & 30 & 51 & 160 & 2,200 \\
\hline 47 & Little Blue River at Hollenberg, Kans. & 44 & 17 & 39 & 88 & 400 & 3,200 \\
\hline 50 & Black Vermillion River near Frankfort, Kans. & 47 & 18 & 40 & 100 & 150 & 1,600 \\
\hline 52 & Big Blue River near Manhattan, Kans. & 41 & 7 & 13 & 22 & 35 & 110 \\
\hline 59 & Mill Creek near Paxico, Kans. & 42 & 11 & 19 & 28 & $49^{\circ}$ & 280 \\
\hline 62 & Kansas River at Topeka, Kans. & 41 & 35 & 49 & 100 & 200 & 550 \\
\hline 72 & Delaware River near Muscotah, Kans. & 41 & 10 & 16 & 34 & 62 & 240 \\
\hline 74 & Delaware River below Perry Dam, Kans. & 38 & 5 & 7 & 13 & 31 & 58 \\
\hline 83 & Wakarusa River near Lawrence, Kans. & 39 & 9 & 30 & 52 & 90 & 170 \\
\hline 88 & Kansas River at DeSoto, Kans. & 43 & 16 & 47 & 110 & 280 & 950 \\
\hline \multicolumn{8}{|c|}{ Suspended-sediment particle size, percent finer than 0.004 millimeter } \\
\hline 23 & West Fork Big Blue River near Dorchester, Nebr. & 16 & -- & 67 & 71 & 76 & -- \\
\hline 35 & Big Blue River at Barneston, Nebr. & 10 & -- & 63 & 86 & 94 & -- \\
\hline 47 & Little Blue River at Hollenberg, Kans. & 12 & -- & 56 & 61 & 65 & $\because$ \\
\hline 88 & Kansas River at DeSoto, Kans. & 10 & -- & 42 & 53 & 64 & -- \\
\hline \multicolumn{8}{|c|}{ Suspended-sediment particle size, percent finer than 0.062 millimeter } \\
\hline 1 & Kansas River at Fort Riley, Kans. & 38 & 53 & 82 & 93 & 96 & 99 \\
\hline 3 & Kings Creek near Manhattan, Kans. & 21 & -- & 72 & 84 & 94 & -- \\
\hline 23 & West Fork Big Blue River near Dorchester, Nebr. & 42 & 85 & 93 & 98 & 99 & 100 \\
\hline 35 & Big Blue River at Barneston, Nebr. & 36 & 89 & 96 & 99 & 100 & 100 \\
\hline 47 & Little Blue River at Hollenberg, Kans. & 39 & 52 & 84 & 92 & 96 & 99 \\
\hline 50 & Black Vermillion River near Frankfort, Kans. & 42 & 74 & 89 & 97 & 98 & 100 \\
\hline 52 & Big Blue River near Manhattan, Kans. & 36 & 75 & 90 & 96 & 99 & 100 \\
\hline 59 & Mill Creek near Paxico, Kans. & 36 & 41 & 80 & 95 & 98 & 100 \\
\hline 62 & Kansas River at Topeka, Kans. & 35 & 71 & 87 & 94 & 97 & 99 \\
\hline 72 & Delaware River near Muscotah, Kans. & 36 & 61 & 78 & 97 & 99 & 100 \\
\hline
\end{tabular}


Table 8. Statistical summary of data for suspended-sediment concentration and particle size in lower Kansas River Basin, Kansas and Nebraska, May 1987-April 1990-Continued

\begin{tabular}{|c|c|c|c|c|c|c|c|}
\hline \multirow[b]{2}{*}{$\begin{array}{c}\text { Station } \\
\text { number } \\
\text { (fig. 9) }\end{array}$} & \multirow[b]{2}{*}{ Station name } & \multirow[b]{2}{*}{$\begin{array}{c}\text { Number } \\
\text { of } \\
\text { analyses }\end{array}$} & \multicolumn{5}{|c|}{ Value at Indicated percentlie } \\
\hline & & & 10 & 25 & $\begin{array}{c}50 \text { (me- } \\
\text { dlan) }\end{array}$ & 75 & 90 \\
\hline \multicolumn{8}{|c|}{ Suspended-sediment particle size, percent finer than 0.062 millimeter-Continued } \\
\hline 74 & Delaware River below Perry Dam, Kans. & 32 & 84 & 89 & 97 & 99 & 100 \\
\hline 83 & Wakarusa River near Lawrence, Kans. & 35 & 86 & 93 & 98 & 100 & 100 \\
\hline 88 & Kansas River at DeSoto, Kans. & 38 & 52 & 74 & 87 & 95 & 98 \\
\hline \multicolumn{8}{|c|}{ Suspended-sediment particle size, percent finer than 0.125 millimeter } \\
\hline 23 & West Fork Big Blue River near Dorchester, Nebr. & 11 & -- & 95 & 100 & 100 & $\therefore-$ \\
\hline 35 & Big Blue River at Barneston, Nebr. & 12 & -- & 100 & 100 & 100 & -- \\
\hline 47 & Little Blue River at Hollenberg, Kans. & 13 & -- & 73 & 94 & 99 & -- \\
\hline 83 & Wakarusa River near Lawrence, Kans. & 10 & -- & 100 & 100 & 100 & -- \\
\hline 88 & Kansas River at DeSoto, Kans. & 12 & -- & 57 & 79 & 97 & -- \\
\hline \multicolumn{8}{|c|}{ Suspended-sediment particle size, percent finer than 0.250 millimeter } \\
\hline 23 & West Fork Big Blue River near Dorchester, Nebr. & 11 & -- & 98 & 100 & 100 &.- \\
\hline 35 & Big Blue River at Barneston, Nebr. & 12 & -- & 100 & 100 & 100 & -- \\
\hline 47 & Little Blue River at Hollenberg, Kans. & 13 & -- & 78 & 99 & 100 & -- \\
\hline 83 & Wakarusa River near Lawrence, Kans. & 10 & -- & 100 & 100 & 100 & -- \\
\hline 88 & Kansas River at DeSoto, Kans. & 12 & -- & 67 & 82 & 99 & -- \\
\hline \multicolumn{8}{|c|}{ Suspended-sediment particle size, percent finer than 0.500 millimeter } \\
\hline 23 & West Fork Big Blue River near Dorchester, Nebr. & 11 & -- & 100 & 100 & 100 & -- \\
\hline 35 & Big Blue River at Barneston, Nebr. & 12 & -- & 100 & 100 & 100 & -- \\
\hline 47 & Little Blue River at Hollenberg, Kans. & 13 & -- & 99 & 100 & 100 & -- \\
\hline 83 & Wakarusa River near Lawrence, Kans. & 10 & -- & 100 & 100 & 100 & -- \\
\hline 88 & Kansas River at DeSoto, Kans. & 12 & -- & 91 & 99 & 100 & - \\
\hline \multicolumn{8}{|c|}{ Suspended-sediment particle size, percent finer than 1.00 millimeter } \\
\hline 23 & West Fork Big Blue River near Dorchester, Nebr. & 11 & -- & 100 & 100 & 100 & \\
\hline 35 & Big Blue River at Barneston, Nebr. & 12 & -- & 100 & 100 & 100 & -- \\
\hline 47 & Little Blue River at Hollenberg, Kans. & 13 & -- & 100 & 100 & 100 & -- \\
\hline 83 & Wakarusa River near Lawrence, Kans. & 10 & -- & 100 & 100 & 100 & -- \\
\hline 88 & Kansas River at DeSoto, Kans. & 12 & -- & 100 & 100 & 100 & -- \\
\hline
\end{tabular}



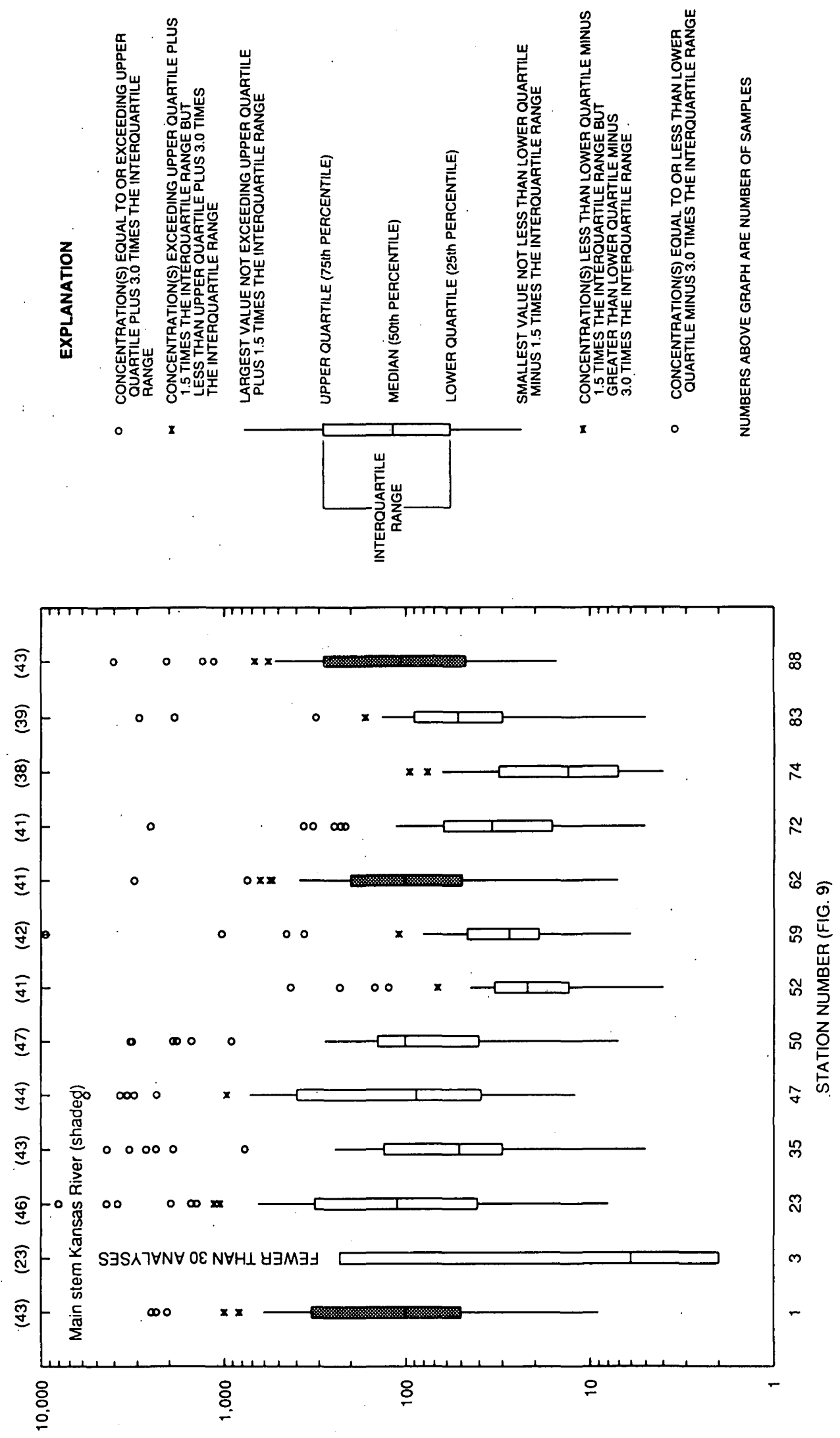

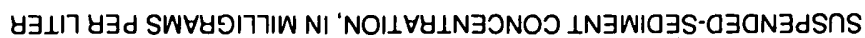


substantially less-than-normal streamflows at the times of sampling.

Most suspended-sediment samples were analyzed for the percentage finer than the 0.062-millimeter particle size, which represents the relative abundance of fine particles derived from. silt and clay, whereas fewer samples were analyzed for other particle sizes. The median percentage of suspended sediment finer than 0.062 millimeter (table 8 ) varied only from 84 to 99 percent within the study unit. The smallest value, 84 percent, for Kings Creek near Manhattan, Kans. (station 3), may reflect thin soils (less abundance of very fine particles) within its drainage area or may have been affected by the automatic sampler at this station. Sediment particles finer than 0.062 millimeter usually have nearly uniform concentration within a vertical section of a stream at any one time, whereas coarser particles increase in concentration from the surface to the streambed. Suspendedsediment samplers leave the bottom 0.3 to $0.5 \mathrm{ft}$ of depth unsampled. Thus, differences in particlesize distribution among any of the stations could result as much from differences in the fraction of depth sampled as from any other cause. Despite the differences among stations, the general abundance of silt and clay in the suspended sediment indicates that the design of detention basins for sediment removal should include consideration of the slow settling velocities of silt and clay.

Seasonal variations, in suspended-sediment concentration are expected because of fluctuations in precipitation and streamflow and because of seasonal patterns of land cover associated with row-crop agriculture. Snow cover, frozen soil, and the large ground-water component of streamflow during the winter also may have some effects. The seasonal variation of suspended-sediment concentration may be important for operation of facilities that treat surface water for municipal or industrial use, for modification of agricultural practices to reduce sediment, and for efficient monitoring. In addition, computation of transport rate or trend uses the relation between concentration and streamflow rate; these computations can be made more reliable by also accounting for seasonal departures from the relation. As shown in figure 15 , bimonthly departures from the relation between suspended-sediment concentrations and streamflow rate were consistent throughout the lower
Kansas River Basin, based on data from 10 of the 13 fixed stations. For the Kansas River stations and tributary stations alike, the largest median negative departures (measured sediment concentration less than that calculated for a given streamflow rate) were for January-February samples, and the largest median positive departures (measured sediment concentration more than that calculated for a given streamflow rate) were for July-August samples. These departures show that, after accounting for the effect of flow, suspendedsediment concentrations were typically smallest during January-February and largest during July-August. The seven tributary stations used in the calculations omitted the three stations immediately downstream from the large reservoirs. For the seven tributary stations, median suspendedsediment concentrations for January-February were 58 percent smaller, and for July-August were 109 percent larger, than for the year as a whole for any given streamflow rate.

\section{Transport Rates}

Suspended-sediment transport rates in the Kansas River increased from 1,500,000 ton/yr at Fort Riley (station 1) to $2,900,000$ ton/yr at Topeka (station 62) and about 4,100,000 ton/yr at DeSoto (station 88) (table 9 and fig. 16). Of the increase from station 1 to 62 , only 9 percent was contributed by the Big Blue River, and the remaining 91 percent was contributed by smaller tributaries and by erosion of the Kansas River channel. Of the calculated increase from station 62 to 88 , only 6 percent was contributed by the Delaware and Wakarusa Rivers (both controlled by reservoirs), and the remaining 94 percent was contributed by other tributaries and erosion of the Kansas River channel. Measurements are not available to show what proportion of that 94 percent was contributed by erosion of the channel.

Relative values of suspended-sediment yields from areas not affected by large reservoirs corresponded approximately with relative sediment concentrations from those areas; that is, areas with large concentrations were characterized also by large yields. This correspondence was more apparent for the 90th-percentile concentrations than for the smaller percentile concentrations because sediment transport at any particular time is 


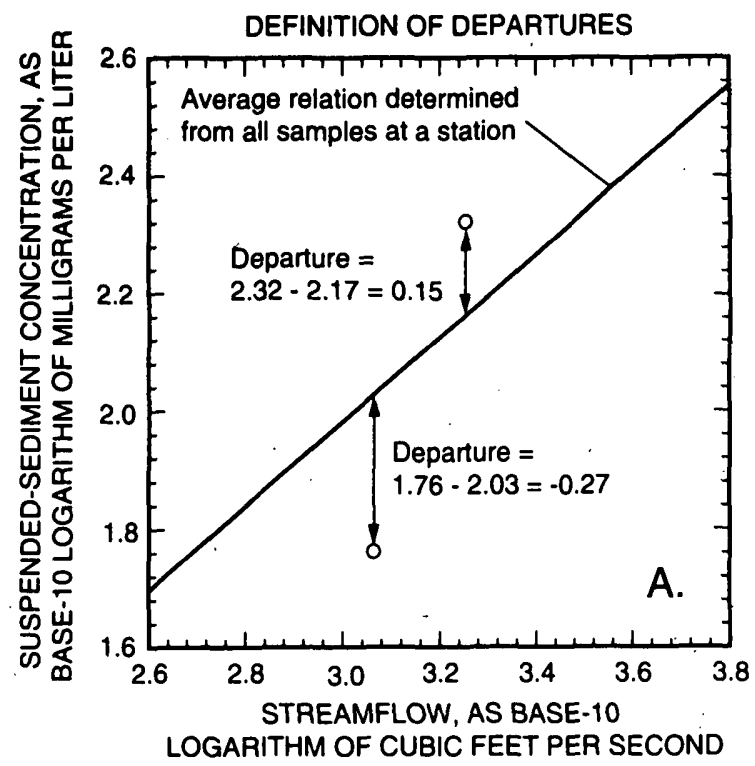

\section{EXPLANATION}

(24) NUMBER OF SAMPLES

75th PERCENTILE
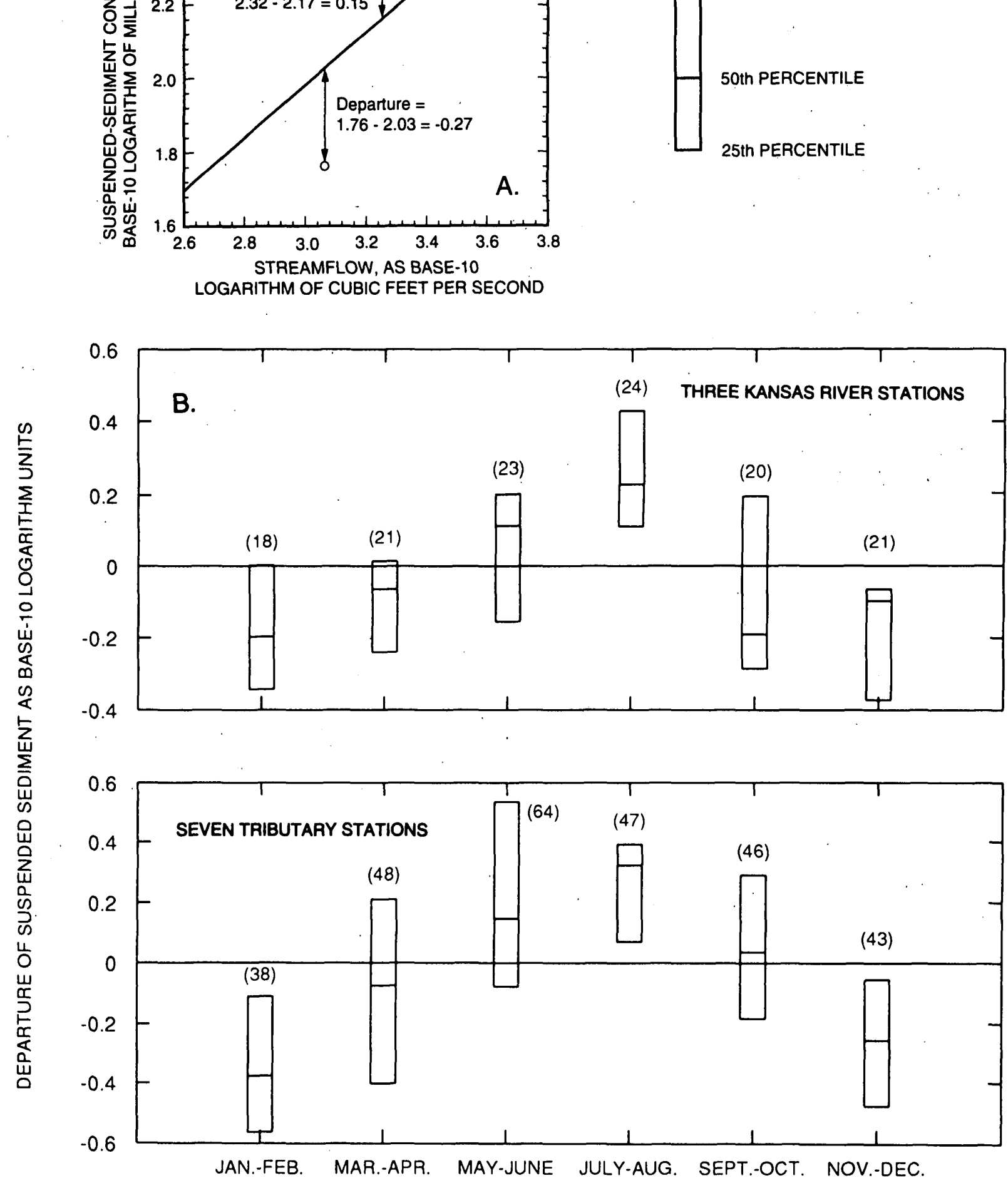

Flgure 15. $(A)$ Definition of and $(B)$ bimonthly departures from relation between suspended-sediment concentration and streamflow rate in the lower Kansas River Basin, Kansas and Nebraska, May 1987-April 1990. 


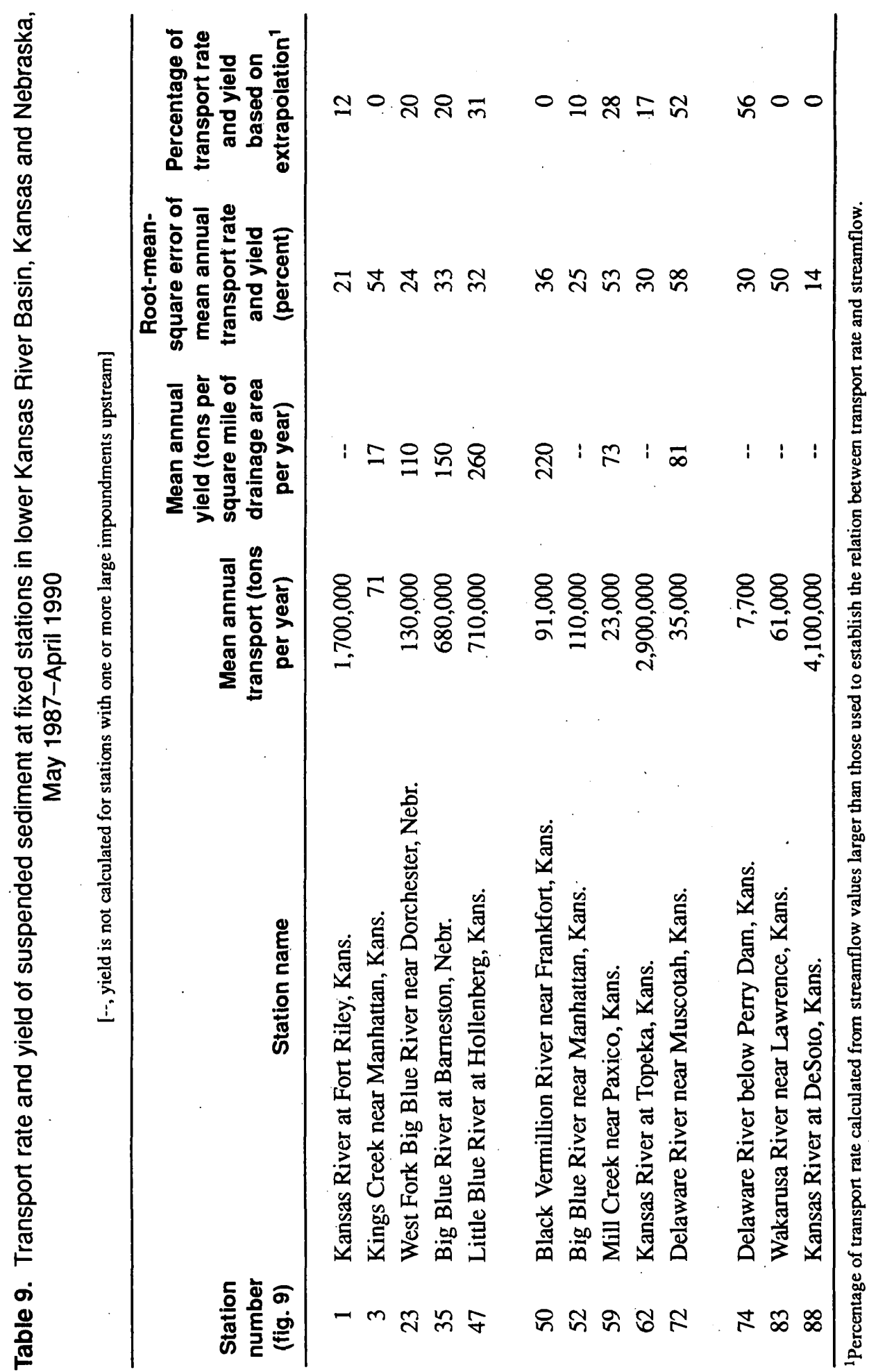




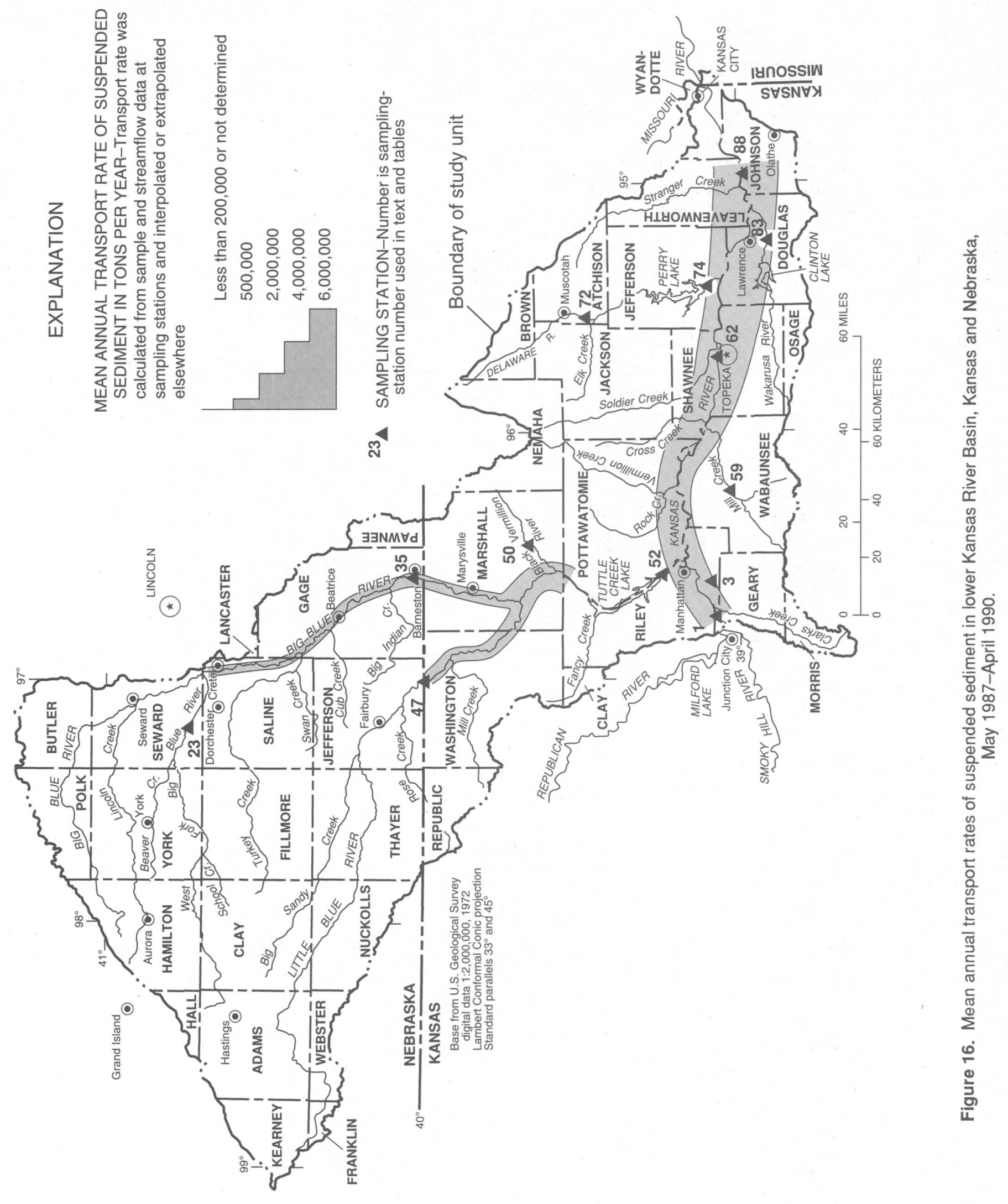


proportional to the product of sediment concentration and streamflow, and large sediment concentrations tend to occur at times of large streamflow. The yield data together with other information provide indications of some general relations of suspended-sediment yield to natural and human factors. However, abnormally dry conditions and large uncertainty factors for some yield calculations reduce confidence in those indications.

The areas having no row crops (station 3 ) and little area of row crops (station 59) had the smallest suspended-sediment yields (17 and 73 ton $/ \mathrm{mi}^{2}$ per year). Dissected areas having medium densities of row-crop land (stations 47 and 50) and medium to high densities of row-crop land with little local relief (stations 23 and 35) had the largest yields (110 to 260 ton $/ \mathrm{mi}^{2}$ per year). Station 72 was the exception for yield as it was for concentrations, having a relatively small yield $\left(81 \mathrm{ton} / \mathrm{mi}^{2}\right.$ per year) although the drainage area has physical and agricultural characteristics similar to the drainage area of station 50 . The small yield at station 72 probably has little relation to human factors but is related to the fact that the streamflow during May 1987-April 1990 was only about 36 percent of the 1970-90 streamflow (table 2).

To provide additional insight to variation in suspended-sediment transport rate in the Kansas River, additional computations were made for the three Kansas River stations to estimate suspendedsediment transport rate for selected low-, medium-, and high-flow years during 1978-90 (table 10). The substantial effect of high flows on sediment transport rate is shown clearly; for example, at the DeSoto station (station 88) the high flow of $16,900 \mathrm{ft}^{3} / \mathrm{s}$ was 530 percent larger than the low flow of $2,700 \mathrm{ft}^{3} / \mathrm{s}$, but the suspended-sediment transport rate.was 900 percent larger in the highflow year. In the downstream direction, the increase of suspended-sediment transport rate in the Kansas River was limited by trapping of sediment in Tuttle Creek, Perry, and Clinton Lakes located on tributaries, whereas the increase of streamflow was subject only to the relatively minor

Table 10. Annual transport rate of suspended sediment at Kansas River stations for selected years of low, medium, and high streamflows, 1978-90 water years

\begin{tabular}{|c|c|c|c|c|c|}
\hline $\begin{array}{c}\text { Station } \\
\text { number } \\
\text { (fig. 9) }\end{array}$ & Station name & $\begin{array}{l}\text { Yearly mean } \\
\text { streamflow } \\
\text { (cublc feet per } \\
\text { second) }\end{array}$ & $\begin{array}{c}\text { Annual } \\
\text { transport rate } \\
\text { (tons per year) }\end{array}$ & $\begin{array}{l}\text { Root-mean- } \\
\text { square error } \\
\text { of mean } \\
\text { annual } \\
\text { transport } \\
\text { rate and } \\
\text { yleld } \\
\text { (percent) }\end{array}$ & $\begin{array}{l}\text { Percentage of } \\
\text { transport rate } \\
\text { and yleld } \\
\text { based on } \\
\text { extrapolation }\end{array}$ \\
\hline \multicolumn{6}{|c|}{ Low streamflow (1989) } \\
\hline 1 & Kansas River at Fort Riley, Kans. & 870 & 450,000 & 31 & 0 \\
\hline 62 & Kansas River at Topeka, Kans. & 2,410 & $1,600,000$ & 37 & 29 \\
\hline 88 & Kansas River at DeSoto, Kans. & 2,700 & $2,100,000$ & 29 & 0 \\
\hline \multicolumn{6}{|c|}{ Medium streamflow (1985) } \\
\hline 1 & Kansas River at Fort Riley, Kans. & 2,200 & $1,600,000$ & 22 & 0 \\
\hline 62 & Kansas River at Topeka, Kans. & 5,020 & $2,600,000$ & 28 & 0 \\
\hline 88 & Kansas River at DeSoto, Kans. & 7,650 & $5,000,000$ & 14 & 0 \\
\hline \multicolumn{6}{|c|}{ High streamflow (1987) } \\
\hline 1 & Kansas River at Fort Riley, Kans. & 6,230 & $7,500,000$ & 28 & 30 \\
\hline 62 & Kansas River at Topeka, Kans. & 13,400 & $13,000,000$ & 41 & 18 \\
\hline 88 & Kansas River at DeSoto, Kans. & 16,900 & $21,000,000$ & 17 & 0 \\
\hline
\end{tabular}

54 Surface-Water-Quality Assessment of the Lower Kansas River Basin, Kansas and Nebraska: Results of Investlgatlons, 1987-90 
effect of evaporation from the lake surfaces. For example, in the medium-flow year, the streamflow increased from Fort Riley to Topeka by 130 percent from 2,200 to $5,020 \mathrm{ft}^{3} / \mathrm{s}$, but the suspended-sediment transport rate increased only 60 percent.

\section{Trends}

Although suspended-sediment data were collected from May 1987 through April 1990 at 13 stations, adequate data for trend tests for at least 10 years through 1990 were available only for five stations. Statistical tests for trend were performed as described by Jordan (1991a) and used programs developed by Schertz and others (1991). The results of trend tests for the longest period available through 1990 for each of the five stations are shown in table 11. Results of trend tests for 1977-90 for the Kansas River at station 88 also are shown for comparison with three other stations for the same period. Results are shown only for flowadjusted suspended-sediment concentration rather than unadjusted concentration because of the close relation between concentration and streamflow.
The downward trend of flow-adjusted suspended-sediment concentration at station 23 on the West Fork Big Blue River cannot be explained by any factors for which data are readily available. However, the drainage area is in the Upper Big Blue Natural Resources District, established in 1972, which has been promoting soil- and waterconservation techniques that are designed to decrease erosion. The upward trend at station 88 on the Kansas River for 1977-90 cannot be readily explained. The riverbanks eroded during this period (Simons, Li, and Associates, Inc., 1984), but the erosion probably was more intense during the early part of the period. Information pertaining to land removed from crop production and to construction of detention structures does not provide definitive reasons for the trends or lack of trends observed.

\section{Nutrients \\ by Wuncheng Wang and G.M. Ferrell}

Nutrients, generally considered to include nitrogen and phosphorus species, are essential to metabolic processes of living organisms. Nutrients

Table 11. Trend-test results for flow-adjusted suspended-sediment concentrations at selected fixed stations in lower Kansas River Basin, Kansas and Nebraska

[Underlined $($ ), significant at 0.1 probability level; $<$, less than]

\begin{tabular}{|c|c|c|c|c|c|}
\hline \multirow[b]{2}{*}{$\begin{array}{c}\text { Station } \\
\text { number } \\
\text { (flg. 9) }\end{array}$} & \multirow[b]{2}{*}{ Station name } & \multirow[b]{2}{*}{$\begin{array}{l}\text { Inclusive } \\
\text { years }\end{array}$} & \multirow[b]{2}{*}{$\begin{array}{l}\text { Number of } \\
\text { years }\end{array}$} & \multicolumn{2}{|c|}{$\begin{array}{l}\text { Results of seasonal Kendall } \\
\text { tests for time trend of } \\
\text { flow-adjusted } \\
\text { suspended-sediment } \\
\text { concentrations }\end{array}$} \\
\hline & & & & $\begin{array}{l}\text { Probabllity } \\
\text { level }\end{array}$ & $\begin{array}{c}\text { Calculated } \\
\text { rate of change } \\
\text { (percentage } \\
\text { year) }\end{array}$ \\
\hline 1 & Kansas River at Fort Riley, Kans. & $1977-90$ & 14 & 0.30 & 3.5 \\
\hline 23 & $\begin{array}{l}\text { West Fork Big Blue River near } \\
\text { Dorchester, Nebr. }\end{array}$ & $1963-90$ & 28 & $<, 005$ & $\therefore 3.9$ \\
\hline 50 & $\begin{array}{l}\text { Black Vermillion River near Frankfort, } \\
\text { Kans. }\end{array}$ & $1977-90$ & 14 & .74 & -.4 \\
\hline 72 & Delaware River near Muscotah, Kans. & $1977-90$ & 14 & .71 & -.6 \\
\hline 88 & Kansas River at DeSoto, Kans. & $1975-90$ & 16 & .72 & 6 \\
\hline & & $1977-90$ & 14 & .05 & $\underline{2.8}$ \\
\hline
\end{tabular}


in surface water are derived from nonpoint and point sources. Nonpoint sources are distributed over relatively large areas and include fertilizer, animal wastes, plant debris, and precipitation; soil erosion and inflow of ground water containing nitrogen and phosphorus are processes that contribute nutrients to surface water. Point sources of nutrients refer to distinct locations and include effluent from municipal and industrial wastewatertreatment plants.

Species of nitrogen in water include nitrate, nitrite, ammonia, and organic nitrogen. Nitrate is the end product of the oxidation of the nitrogen species. Organic nitrogen occurs in particulate form as living organisms and detrital material and in dissolved form as metabolic compounds such as protein or urea. Forms of phosphorus in water include orthophosphate and particulate phosphorus, which are derived from phosphate minerals and from organic phosphates synthesized by living organisms. Speciation of nitrogen and phosphorus can be changed by microbial activities, such as ammonification (organic nitrogen to ammonia), nitrification (ammonia to nitrite and nitrate), denitrification (nitrate and nitrite to nitrogen gases), and cycling of phosphorus between orthophosphate and organic forms.

Plants can assimilate dissolved ammonia, nitrite, nitrate, and orthophosphate. Nutrient enrichment in natural water can promote blooms of nuisance algae and prolific growth of aquatic vascular plants, which can cause taste and odor problems, prematurely clog water-treatment filters, obstruct boat navigation, and decrease aesthetic value (National Academy of Sciences, 1969). Effects of nutrient enrichment commonly are greater in reservoirs than in streams because the slow-moving water of reservoirs provides more opportunity for plant growth to occur.

In the lower Kansas River Basin from 1987-90, about 274,000 ton/yr of nitrogen and 46,000 ton/yr of phosphorus were estimated to have been derived from fertilizer, livestock wastes, effluents from municipal and industrial wastewater-treatment plants, and precipitation (fig. 17). These estimates indicate that the principal sources of nitrogen and phosphorus were fertilizer and livestock. Terrestrial processes, including assimilation by vegetation and removal of assimilated nutrients by harvesting, decrease nutrient inputs to streams (Peterjohn and Correll, 1984). Nutrient contributions from wastewater effluent generally are small, yet essentially all of the nitrogen and phosphorus in wastewater effluent enter streams. The effect of wastewater effluent on receiving-water quality can be great, particularly during low-flow conditions and in small streams where the capacity for dilution is small. Additional, unquantified nutrient sources include plant debris, nitrogen fixation, and soil and rock that contain phosphorus minerals. Nitrogen can be removed from surface water by denitrification, ammonia volatilization, assimilation by plants, and sorption of ammonium onto sediment and subsequent deposition. Phosphorus can be removed by assimilation by plants and sorption onto sediment particles and subsequent deposition.

The U.S. Environmental Protection Agency (1990) has established a Maximum Contaminant Level (MCL) of $10 \mathrm{mg} / \mathrm{L}$ for nitrate as nitrogen in public-drinking water supplies. Methemoglobinemia in infants (blue-baby syndrome) is associated with nitrate in drinking water at concentrations exceeding that value. An ammonia standard for effluent is enforceable under the National Pollutant Discharge Elimination System; $\mathrm{pH}$ and temperature affect ammonia toxicity in water. The un-ionized form of ammonia is toxic to aquatic animals and plants. The U.S. Environmental Protection Agency has not established a MCL for phosphorus in public-drinking water supplies.

Nutrient data are from samples collected at least monthly from May 1987 through April 1990 at the 13 fixed stations. Data also were collected from 49 of the 77 synoptic stations during five periods representing various seasonal streamflow conditions to provide additional information about nutrient distribution in streams in the study unit.

\section{Concentrations}

A statistical summary of nutrient data for water collected from May 1987 through April 1990 from the fixed stations within the study unit is listed in table 12 . Concentrations of nitrite were very small compared to nitrate concentrations; hereafter in the text, nitrite plus nitrate is referred to as nitrate. No concentrations of dissolved nitrate as nitrogen in water samples from the fixed stations exceeded 


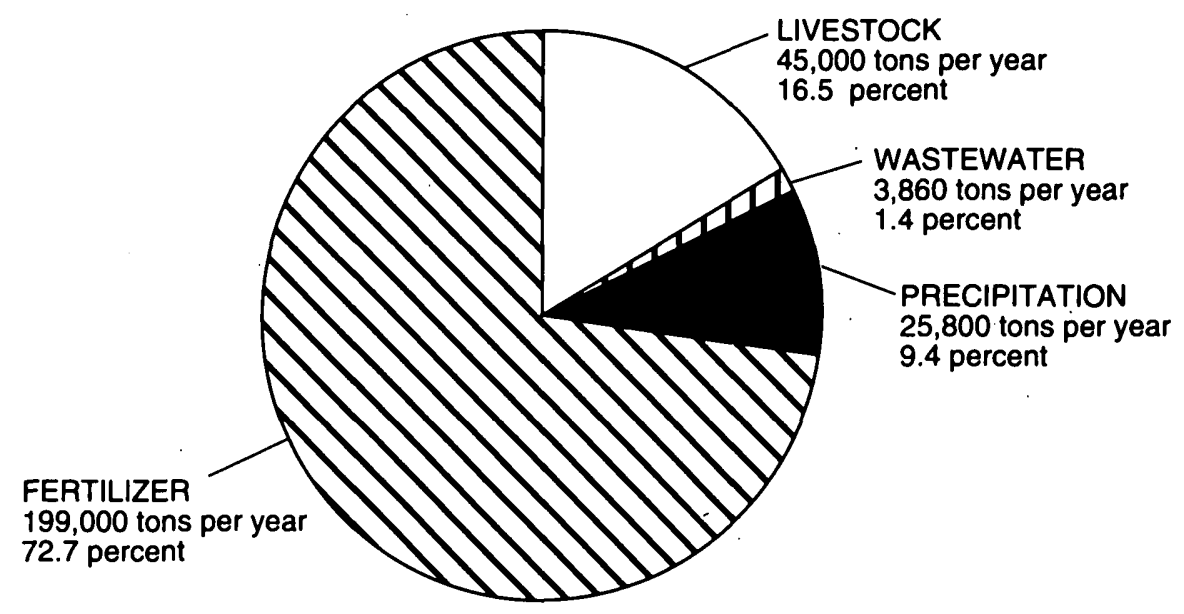

TOTAL $=273,660$ TONS PER YEAR, 1987-90

B. TOTAL PHOSPHORUS

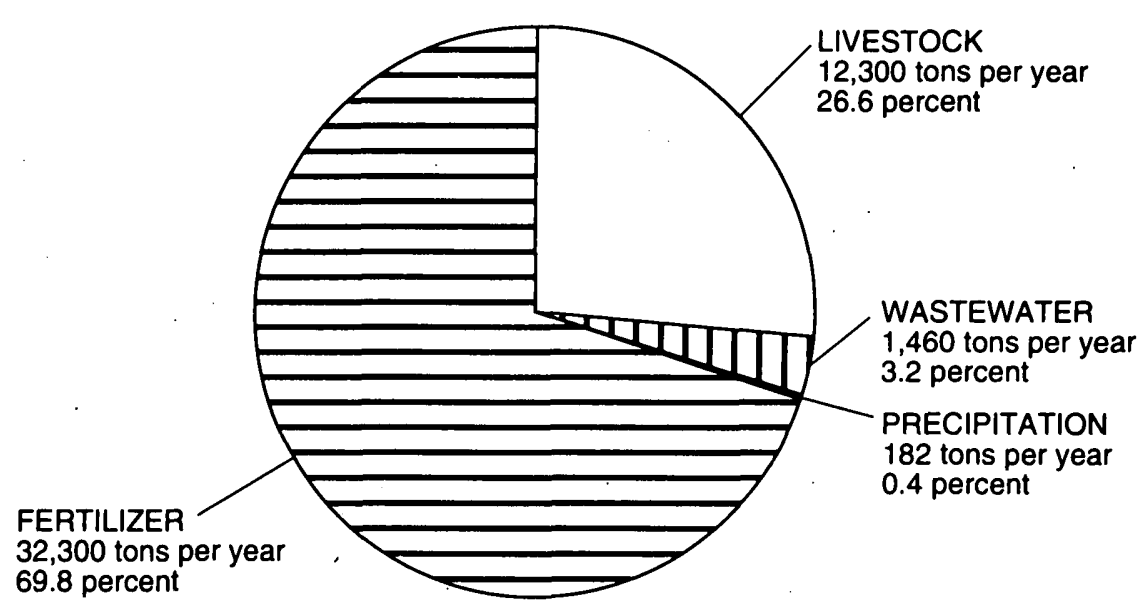

TOTAL $=46,242$ TONS PER YEAR, 1987-90

Estimates for fertilizer and livestock based on Van Dyne and Gilbertson (1978); Kansas State Board of Agriculture (1988, 1989, 1990); Nebraska Agricultural Statistics Service $(1988,1989,1990)$; U.S. Bureau of the Census (1989a, 1989b); Kansas State University (1991); and U.S. Department of Agriculture (1991a, 1991b). Estimates for wastewater based on Gianessi (1986). Estimates for precipitation based on Robertson and Wojciechowski (1986a, 1986b).

Figure 17. Sources and estimated annual amounts of $(A)$ total nitrogen and $(B)$ total phosphorus in lower Kansas River Basin, Kansas and Nebraska, 1987-90. 
Table 12. Statistical summary of data for nutrients in water from fixed stations in lower Kansas River Basin, Kansas and Nebraska, May 1987-April 1990

[Concentrations in milligrams per liter, this table includes only those stations having 10 or more analyses; --, the 10- and 90-percentile values are not shown for stations having fewer than 30 analyses]

\begin{tabular}{|c|c|c|c|c|c|c|c|}
\hline \multirow{2}{*}{$\begin{array}{c}\text { Station } \\
\text { number } \\
\text { (flg. 9) }\end{array}$} & \multirow[b]{2}{*}{ Station name } & \multirow{2}{*}{$\begin{array}{l}\text { Number } \\
\text { of } \\
\text { analy- } \\
\text { ses }\end{array}$} & \multicolumn{5}{|c|}{ Value at indicated percentile } \\
\hline & & & 10 & 25 & $\begin{array}{l}50 \text { (me- } \\
\text { dlan) }\end{array}$ & 75 & 100 \\
\hline \multicolumn{8}{|c|}{ Nitrite plus nitrate, dissolved, as $\mathbf{N}$} \\
\hline 1 & Kansas River at Fort Riley, Kans. & 42 & $<0.10$ & $<0.10$ & 0.49 & 0.88 & 1.1 \\
\hline 3 & Kings Creek near Manhattan, Kans. & 20. & -- & $<.10$ & $<.10$ & .11 & -- \\
\hline 23 & West Fork Big Blue River near Dorchester, Nebr. & 55 & 1.5 & 1.9 & 2.4 & 2.8 & 3.5 \\
\hline 35 & Big Blue River at Barneston, Nebr. & 43 & .52 & 1.5 & 2.2 & 3.0 & 3.4 \\
\hline 47 & Little Blue River at Hollenberg, Kans. & 43 & .39 & .71 & 1.3 & 1.6 & 2.4 \\
\hline 50 & Black Vermillion River near Frankfort, Kans. & 46 & $<.10$ & .13 & .53 & 1.3 & 2.1 \\
\hline 52 & Big Blue River near Manhattan, Kans. & 40 & .31 & .70 & .91 & 1.3 & 1.8 \\
\hline 59 & Mill Creek near Paxico, Kans. & 43 & $<.10$ & $<.10$ & $<.10$ & .32 & .55 \\
\hline 62 & Kansas River at Topeka, Kans. & 43 & $<.10$ & $<.10$ & .60 & .95 & 1.5 \\
\hline 72 & Delaware River near Muscotah, Kans. & 42 & $<.10$ & $<.10$ & .18 & .48 & 1.7 \\
\hline 74 & Delaware River below Perry Dam, Kans. & 37 & $<.10$ & .10 & .22 & .47 & .69 \\
\hline 83 & Wakarusa River near Lawrence, Kans. & 38 & $<.01$ & $<.10$ & .12 & .24 & .46 \\
\hline 88 & Kansas River at DeSoto, Kans. & 43 & $<.10$ & .21 & .71 & 1.0 & 1.5 \\
\hline \multicolumn{8}{|c|}{ Nitrogen, ammonia, dissolved, as $\mathrm{N}$} \\
\hline 1 & Kansas River at Fort Riley, Kans. & 42 & .02 & .03 & .05 & .07 & .22 \\
\hline 3 & Kings Creek near Manhattan, Kans. & 20 & -- & $<.01$ & .02 & .04 & -- \\
\hline 23 & West Fork Big Blue River near Dorchester, Nebr. & 55 & .02 & .04 & .09 & .28 & .62 \\
\hline 35 & Big Blue River at Barneston, Nebr. & 43 & .01 & .03 & .06 & .27 & .47 \\
\hline 47 & Little Blue River at Hollenberg, Kans. & 43 & .01 & .03 & .05 & .13 & .19 \\
\hline 50 & Black Vermillion River near Frankfort, Kans. & 46 & .02 & .03 & .05 & .14 & .32 \\
\hline 52 & Big Blue River near Manhattan, Kans. & 40 & .01 & .02 & .04 & .06 & .20 \\
\hline 59 & Mill Creek near Paxico, Kans. & 42 & .01 & .02 & .03 & .04 & .07 \\
\hline 62 & Kansas River at Topeka, Kans. & 42 & $<.01$ & .02 & .03 & .05 & .07 \\
\hline 72 & Delaware River near Muscotah, Kans. & 39 & $<.01$ & .02 & .03 & .07 & .11 \\
\hline 74 & Delaware River below Perry Dam, Kans. & 38 & $<.01$ & .01 & .05 & .13 & .31 \\
\hline 83 & Wakarusa River near Lawrence, Kans. & 37 & $<.01$ & $<.01$ & .02 & .04 & .11 \\
\hline 88 & Kansas River at DeSoto, Kans. & 43 & .01 & .02 & .03 & .13 & .31 \\
\hline
\end{tabular}


Table 12. Statistical summary of data for nutrients in water from fixed stations in lower Kansas River Basin, Kansas and Nebraska, May 1987-April 1990-Continued

\begin{tabular}{|c|c|c|c|c|c|c|c|}
\hline \multirow[b]{2}{*}{$\begin{array}{l}\text { Station } \\
\text { number } \\
\text { (fig. 9) }\end{array}$} & \multirow[b]{2}{*}{ Station name } & \multirow{2}{*}{$\begin{array}{c}\text { Number } \\
\text { of } \\
\text { analy- } \\
\text { ses }\end{array}$} & \multicolumn{5}{|c|}{ Value at Indicated percentile } \\
\hline & & & 10 & 25 & $\begin{array}{l}50 \text { (me- } \\
\text { dlan) }\end{array}$ & 75 & 100 \\
\hline \multicolumn{8}{|c|}{ Nitrogen, ammonia plus organic, total, as $\mathbf{N}$} \\
\hline 1 & Kansas River at Fort Riley, Kans. & 43 & 0.4 & 0.6 & 0.8 & 1.0 & 1.8 \\
\hline 3 & Kings Creek near Manhattan, Kans. & 24 & -- & .2 & .4 & .9 & -- \\
\hline 23 & West Fork Big Blue River near Dorchester, Nebr. & 53 & .4 & .7 & 1.2 & 1.6 & 3.0 \\
\hline 35 & Big Blue River at Barneston, Nebr. & 43 & .7 & 1.0 & 1.5 & 1.8 & 2.5 \\
\hline 47 & Little Blue River at Hollenberg, Kans. & 44 & .2 & .4 & .6 & 1.6 & 2.1 \\
\hline 50 & Black Vermillion River near Frankfort, Kans. & 45 & .4 & .5 & .8 & 1.2 & 1.7 \\
\hline 52 & Big Blue River near Manhattan, Kans. & 41 & .5 & .5 & .7 & .9 & 1.2 \\
\hline 59 & Mill Creek near Paxico, Kans. & 42 & .2 & .3 & .4 & 6 & .8 \\
\hline 62 & Kansas River at Topeka, Kans. & 42 & .5 & .6 & .8 & 1.0 & 1.4 \\
\hline 72 & Delaware River near Muscotah, Kans. & 41 & .3 & .5 & .6 & 1.0 & 1.3 \\
\hline 74 & Delaware River below Perry Dam, Kans. & 38 & .4 & .5 & .6 & .7 & 1.1 \\
\hline 83 & Wakarusa River near Lawrence, Kans. & 37 & .4 & .5 & 6 & .8 & 1.0 \\
\hline 88 & Kansas River at DeSoto, Kans. & 43 & .5 & .7 & 1.1 & 1.4 & 1.8 \\
\hline \multicolumn{8}{|c|}{ Phosphorus, total, as $\mathbf{P}$} \\
\hline 1 & Kansas River at Fort Riley, Kans. & 43 & .11 & .13 & .16 & .23 & .37 \\
\hline 3 & Kings Creek near Manhattan, Kans. & 24 & -- & .02 & .03 & .15 & -- \\
\hline 23 & West Fork Big Blue River near Dorchester, Nebr. & 54 & .46 & .57 & .64 & .77 & 1.2 \\
\hline 35 & Big Blue River at Barneston, Nebr. & 43 & .42 & .52 & .58 & .68 & .78 \\
\hline 47 & Little Blue River at Hollenberg, Kans. & 44 & .22 & .25 & .31 & .48 & .71 \\
\hline 50 & Black Vermillion River near Frankfort, Kans. & 46 & .11 & .14 & .22 & .28 & .40 \\
\hline 52 & Big Blue River near Manhattan, Kans. & 41 & .07 & .09 & .12 & .19 & .27 \\
\hline 59 & Mill Creek near Paxico, Kans. & 42 & .02 & .03 & .04 & .06 & .11 \\
\hline 62 & Kansas River at Topeka, Kans. & 42 & .08 & .10 & .16 & .23 & .34 \\
\hline 72 & Delaware River near Muscotah, Kans. & 39 & .09 & .11 & .14 & .22 & .45 \\
\hline 74 & Delaware River below Perry Dam, Kans. & 38 & .02 & .03 & .05 & .09 & .20 \\
\hline 83 & Wakarusa River near Lawrence, Kans. & 38 & .03 & .04 & .07 & .12 & .20 \\
\hline 88 & Kansas River at DeSoto, Kans. & 43 & .13 & .20 & .28 & .40 & .43 \\
\hline \multicolumn{8}{|c|}{ Phosphorus, dissolved, as P } \\
\hline 35 & Big Blue River at Barneston, Nebr. & 22 & -- & 0.38 & 0.44 & 0.51 & -- \\
\hline 72 & Delaware River near Muscotah, Kans. & 39 & $<.01$ & .04 & .07 & .10 & .18 \\
\hline 74 & Delaware River below Perry Dam, Kans. & 37 & $<.01$ & $<.01$ & .02 & .03 & .07 \\
\hline 83 & Wakarusa River near Lawrence, Kans. & 38 & $<.01$ & $<.01$ & .02 & .03 & .05 \\
\hline
\end{tabular}


Table 12. Statistical summary of data for nutrients in water from fixed stations in lower Kansas River Basin, Kansas and Nebraska, May 1987-April 1990-Continued

\begin{tabular}{|c|c|c|c|c|c|c|c|}
\hline \multirow{2}{*}{$\begin{array}{c}\text { Station } \\
\text { number } \\
\text { (flg. 9) }\end{array}$} & \multirow[b]{2}{*}{ Station name } & \multirow{2}{*}{$\begin{array}{c}\text { Number } \\
\text { of } \\
\text { analy- } \\
\text { ses }\end{array}$} & \multicolumn{5}{|c|}{ Value at indicated percentile } \\
\hline & & & 10 & 25 & $\begin{array}{l}50 \text { (me- } \\
\text { dian) }\end{array}$ & 75 & 100 \\
\hline \multicolumn{8}{|c|}{ Phosphorus, orthophosphate, dissolved, as P } \\
\hline 1 & Kansas River at Fort Riley, Kans. & 42 & 0.02 & 0.04 & 0.07 & 0.10 & 0.14 \\
\hline 3 & Kings Creek near Manhattan, Kans. & 20 & -- & $<.01$ & .02 & .03 & -- \\
\hline 23 & West Fork Big Blue River near Dorchester, Nebr. & 55 & .23 & .34 & .39 & .50 & .58 \\
\hline 35 & Big Blue River at Barneston, Nebr. & 43 & .20 & .34 & .39 & .46 & .55 \\
\hline 47 & Little Blue River at Hollenberg, Kans. & 43 & .14 & .17 & .21 & .24 & .28 \\
\hline 50 & Black Vermillion River near Frankfort, Kans. & 46 & .06 & .07 & .11 & .13 & .16 \\
\hline 52 & Big Blue River near Manhattan, Kans. & 40 & .03 & .05 & .09 & .14 & .18 \\
\hline 59 & Mill Creek near Paxico, Kans. & 42 & $<.01$ & $<.01$ & .01 & .02 & .04 \\
\hline 62 & Kansas River at Topeka, Kans. & 42 & $<.01$ & .01 & .06 & .11 & .15 \\
\hline 72 & Delaware River near Muscotah, Kans. & 22 & -- & .04 & .05 & .07 & -- \\
\hline 74 & Delaware River below Perry Dam, Kans. & 20 & -- & $<.01$ & .02 & .03 & -- \\
\hline 83 & Wakarusa River near Lawrence, Kans. & 19 & -- & $<.01$ & .01 & .02 & -- \\
\hline 88 & Kansas River at DeSoto, Kans. & 42 & .04 & .07 & .13 & .18 & .26 \\
\hline
\end{tabular}

the $\mathrm{MCL}$ of $10 \mathrm{mg} / \mathrm{L}$. Median concentrations of dissolved nitrate were larger at stations on the Big and Little Blue Rivers than elsewhere in the study unit. The large median concentrations in samples from the West Fork Big Blue River near Dorchester, Nebr. (station 23), and the Big Blue River at Barneston, Nebr. (station 35), reflect the intense cultivation and associated fertilizer application in drainage areas upstream of these stations. Water samples from Kings Creek near Manhattan, Kans. (station 3), which drains an area of native prairie, contained the smallest median concentrations of nitrogen from 1978-90 (Stamer and Jordan, 1991; table 12). Nitrogen in Kings Creek is derived from precipitation and other natural processes, with minimal effect from human activities.

The median concentration of dissolved ammonia as nitrogen was less than $0.1 \mathrm{mg} / \mathrm{L}$ in all water samples from fixed stations (table 12). Dissolved-ammonia concentrations generally were larger in the Big and Little Blue River subbasins than elsewhere in the study unit. Concentrations of ammonia in those samples, based on $\mathrm{pH}$ and temperature, did not exceed the U.S. Environmental Protection Agency's freshwater acute criterion for un-ionized ammonia. Ammonia concentrations exceeded the freshwater chronic criterion for un-ionized ammonia, based on $\mathrm{pH}$ and temperature, in one sample from the West Fork Big Blue River near Dorchester, Nebr. (station 23), three samples from the Big Blue River at Barneston, Nebr. (station 35), and three samples from the Kansas River at DeSoto, Kans. (station 88). Sources of ammonia in these streams include wastewater, fertilizer, and livestock wastes.

Concentrations of dissolved nitrate and total ammonia plus organic nitrogen from a synoptic survey in November 1988 are shown in figures 18 and 19, respectively. The largest nitrate concentrations (fig. 18) generally were in samples from areas with the most intensive agricultural activity, particularly irrigated cropland in the northern part of the study unit. The two largest concentrations of total ammonia plus organic nitrogen (fig. 19) were in samples from the West Fork Big Blue River near Hastings, Nebr. (station 16), and Lincoln Creek near Aurora, Nebr. (station 9). Municipal waste- 


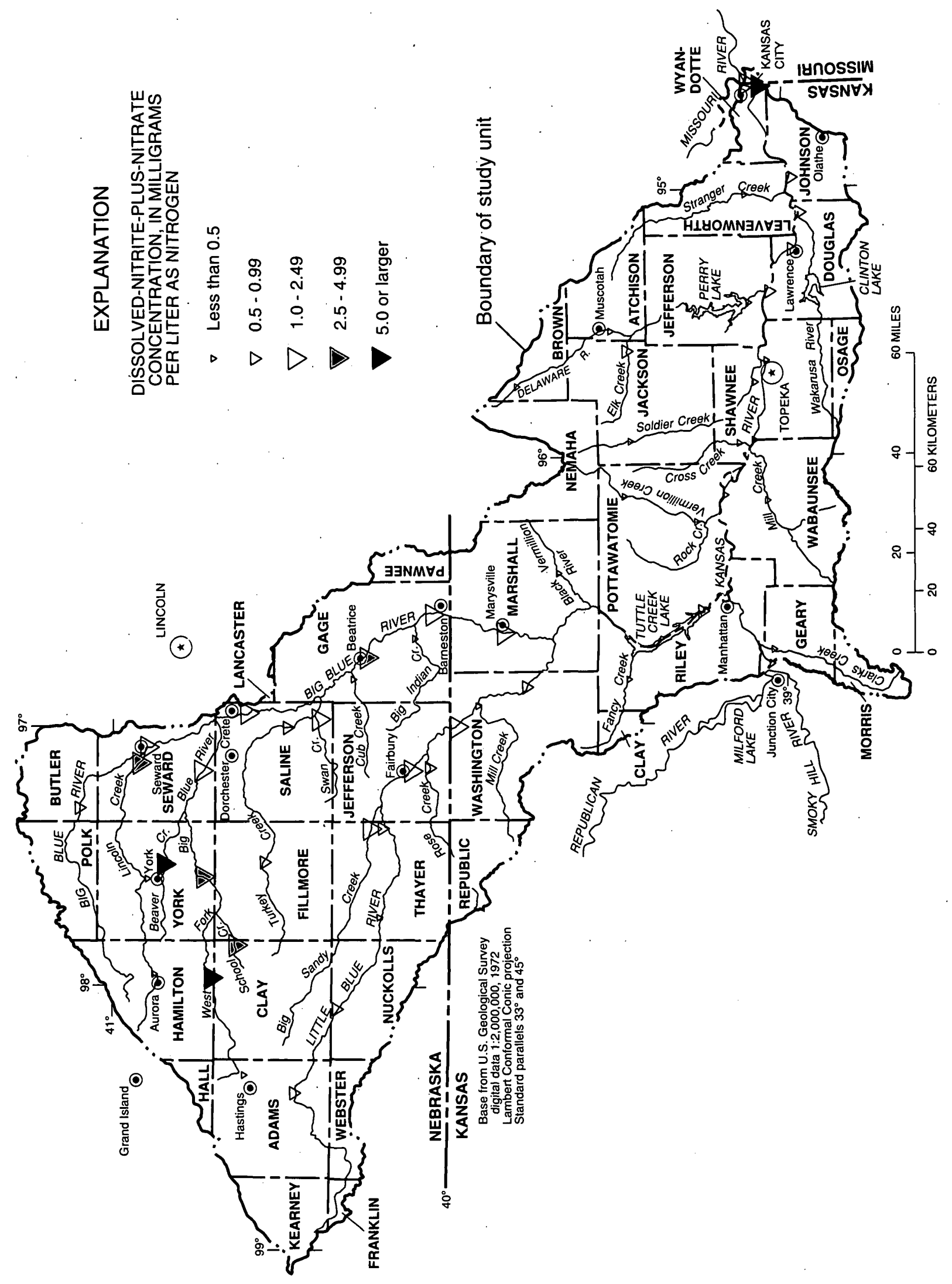

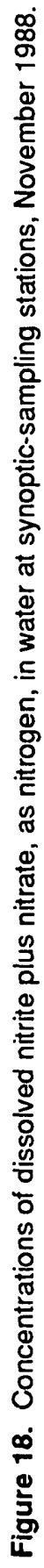




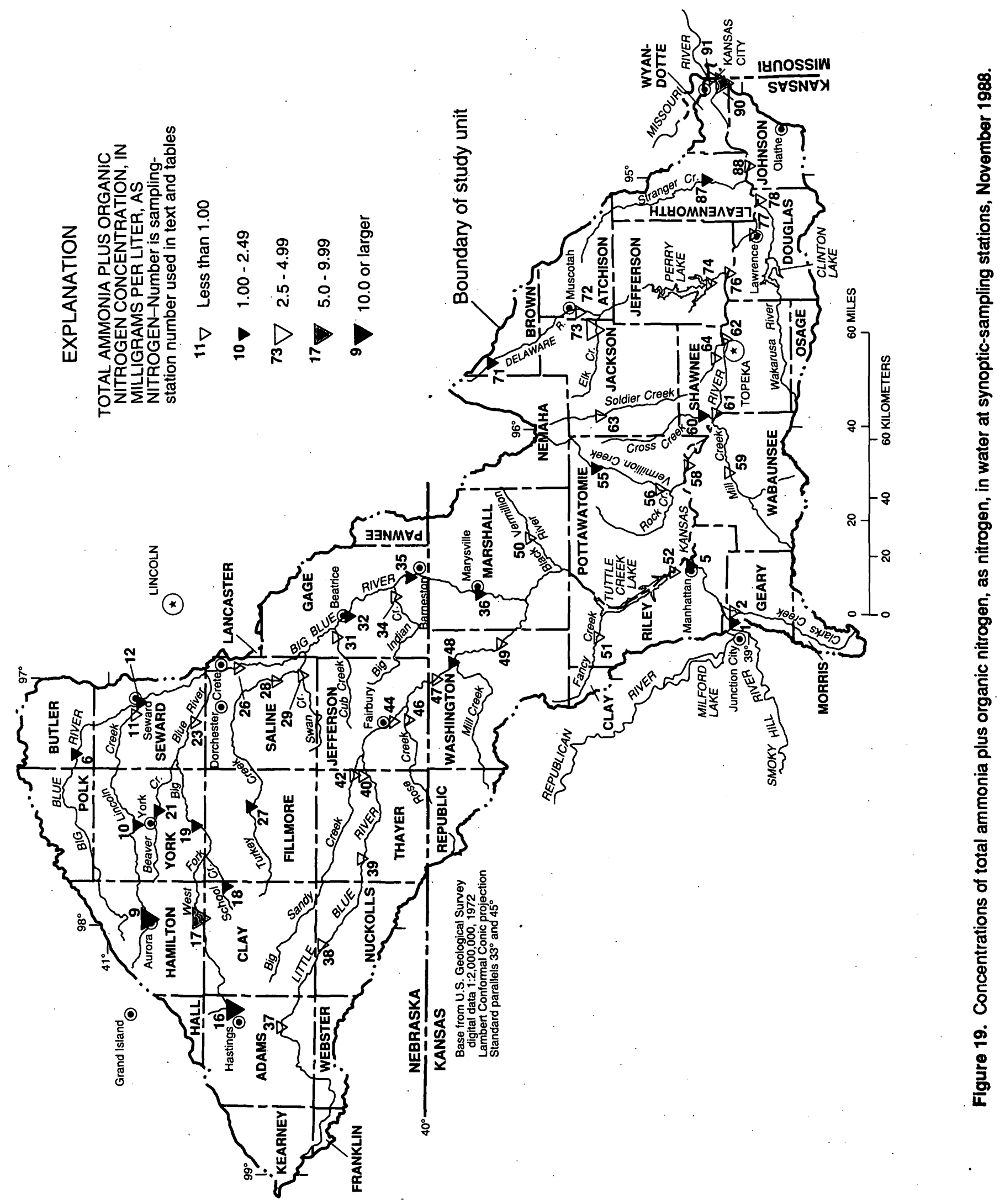

62 Surface-Water-Quality Assessment of the Lower Kansas River Basin, Kansas and Nebraska: Results of Investigations, 1987-90 
water effluent, composing a substantial part of the streamflow at these sites under the low-flow conditions that prevailed, probably was the principal source of ammonia and organic nitrogen. Concentrations of dissolved nitrate and total ammonia plus organic nitrogen showed generally similar distributions during the other synoptic surveys of September 1987, July 1988, and March 1989.

Seasonal distributions of dissolved-nitrate concentrations are shown in figure 20. Large median concentrations from December to February may reflect decreased assimilation of nitrate by plants during the winter; this seasonal pattern is most apparent in the intensively cropped Big and Little Blue River subbasins (stations 23, 35, and 47). Median dissolved-ammonia concentrations in samples from most fixed stations were larger during winter (December through February) than during other seasons (fig. 21). This may be due to decreases in ammonia uptake by plants, in ammonia volatilization, and in oxidation of ammonia to nitrate in streams during the colder months. The large concentrations of dissolved ammonia during the winter in the Kansas River at DeSoto, Kans. (station 88) reflect decreased oxidation of ammonia to nitrate; this station is downstream from municipal wastewater discharges at Topeka and Lawrence. Concentrations of total ammonia plus organic nitrogen (fig. 19) generally were largest during summer and smallest during fall and winter. This variation may relate to runoff, generated by intense summer thunderstorms, that contributes increased quantities of organic nitrogen from livestock wastes and decaying vegetation.

A statistical summary of phosphorus concentrations in water collected at fixed stations is listed in table 12. Total phosphorus concentrations frequently exceeded the value recommended by the U.S. Environmental Protection Agency (1987) for minimizing the potential of eutrophication $(0.1 \mathrm{mg} / \mathrm{L})$. Concentrations of total phosphorus generally were much larger in the upper part of the study unit (stations 23, 35, and 47) than in the lower part. The larger concentrations in the upper part probably reflect the intensive cultivation of row crops and associated application of phosphorus fertilizer. Concentrations of dissolved orthophosphate showed similar areal variations.

Concentrations of total phosphorus generally were much smaller at stations downstream from reservoirs than those upstream from reservoirs. The median concentration of total phosphorus in the Big Blue River near Manhattan, Kans. (station 52, below Tuttle Creek Lake) was $0.12 \mathrm{mg} / \mathrm{L}$, whereas median concentrations upstream of Tuttle Creek Lake ranged from $0.22 \mathrm{mg} / \mathrm{L}$ in the Black Vermillion River near Frankfort, Kans. (station 50), to $0.58 \mathrm{mg} / \mathrm{L}$ in the Big Blue River at Bameston, Nebr. (station 35). The median concentration of total phosphorus in the Delaware River below Perry Dam, Kans. (station 74), was $0.05 \mathrm{mg} / \mathrm{L}$, as compared to $0.14 \mathrm{mg} / \mathrm{L}$ in the Delaware River near Muscotah, Kans. (station 72), which is upstream of Perry Lake. Large reservoirs such as Tuttle Creek and Perry Lakes typically trap nearly all the inflow of sediment, which may contain particulate phosphorus. For example, 90th-percentile concentrations of suspended sediment during May 1987April 1990 (table 8) were 1,600 to $3,200 \mathrm{mg} / \mathrm{L}$ at stations upstream of Tuttle Creek Lake (stations 35, 47, and 50) and only $110 \mathrm{mg} / \mathrm{L}$ downstream from Tuttle Creek Lake (station 52).

Concentrations of total phosphorus from the November 1988 synoptic survey are shown in figure 22. In general, the largest concentrations of total phosphorus were in small streams that receive effluent from municipal wastewater-treatment plants (fig. 11).

Median concentrations of total phosphorus in unregulated streams generally were largest during the summer, from June through August (fig. 23), and coincided with the occurrence of the seasonally largest concentrations of suspended sediment (fig. 15). Concentrations of dissolved orthophosphate (not illustrated) generally were smallest during the spring and summer and may correspond to increased rates of phosphorus assimilation by plants during the warmer seasons.

\section{Transport Rates}

Mean annual transport rates and yields of dissolved nitrate, dissolved ammonia, and total ammonia plus organic nitrogen, are listed in table 13. Mean annual transport rate of dissolved nitrate generally was largest at stations along the main stem of the Kansas River. Mean annual yields of dissolved nitrate were largest where cropland predominates, such as areas drained by 

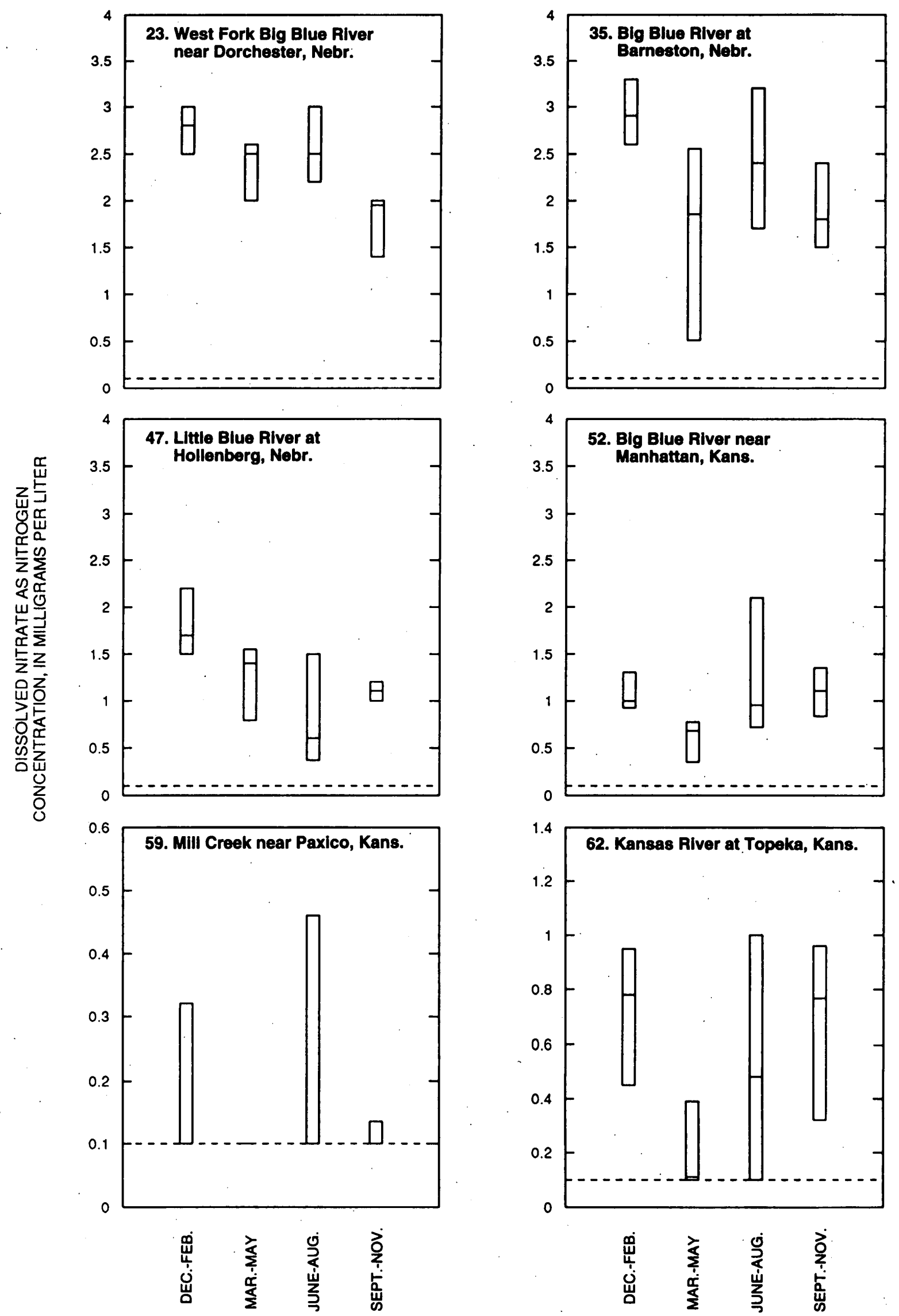

Figure 20. Seasonal variations in concentrations of dissolved nitrite plus nitrate, as nitrogen, in water at selected fixed stations in lower Kansas River Basin, Kansas and Nebraska, May 1987-April 1990. 

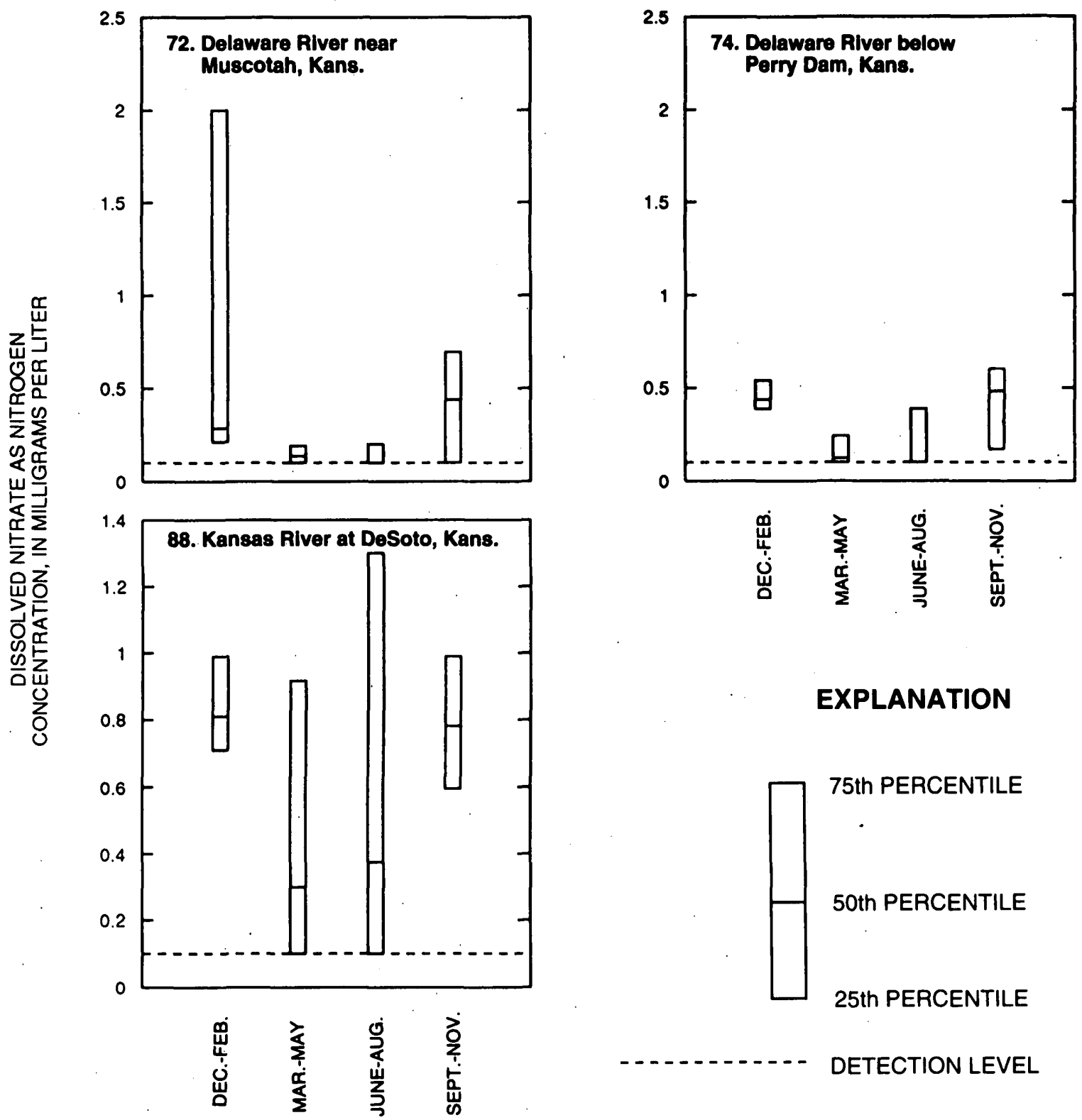

\section{EXPLANATION}

75th PERCENTILE

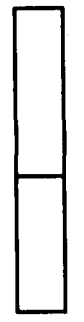

.

50th PERCENTILE

25th PERCENTILE

DETECTION LEVEL

NUMBER AT TOP OF EACH GRAPH IS STATION NUMBER FROM FIGURE 9

Figure 20. Seasonal variations in concentrations of dissolved nitrite plus nitrate, as nitrogen, in water at selected fixed stations in lower Kansas River Basin, Kansas and Nebraska, May 1987-April 1990-Continued

the Big Blue River (stations 35 and 52) and the Delaware River upstream of Perry Lake (station 72). Mean annual yields of dissolved nitrate were smallest in the lower part of the study unit (stations 3,59,74, and 83) where pasture and rangeland are major land uses. Mean annual yields were smaller downstream from Tuttle Creek Lake (station 52) and Perry Lake (station 74) than at most stations upstream of these reservoirs (stations
35,50 , and 72). The effects of the reservoirs may include assimilation of nitrate by aquatic plants.

Transport rate of total ammonia plus organic nitrogen in the Big Blue River near Manhattan, Kans. (station 52), downstream from Tuttle Creek Lake, was 1,400 ton/yr, whereas the combined transport rate for stations upstream from the lake (stations 35, 47, and 50) was 2,260 ton/yr. The loss of total ammonia plus organic nitrogen within the 

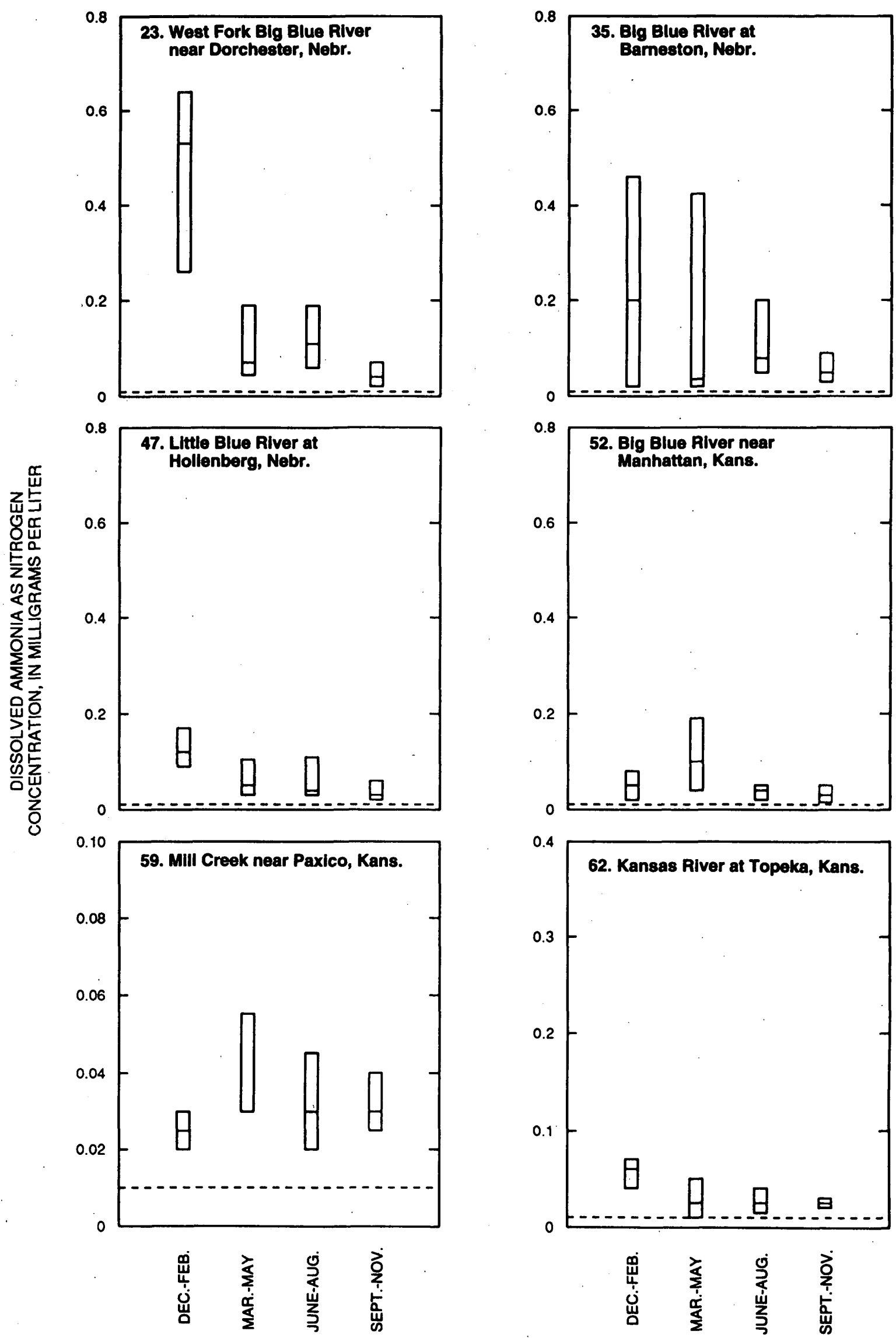

Figure 21. Seasonal variations in concentrations of dissolved ammonia, as nitrogen, in water at selected fixed stations in lower Kansas River Basin, Kansas and Nebraska, May 1987-April 1990. 

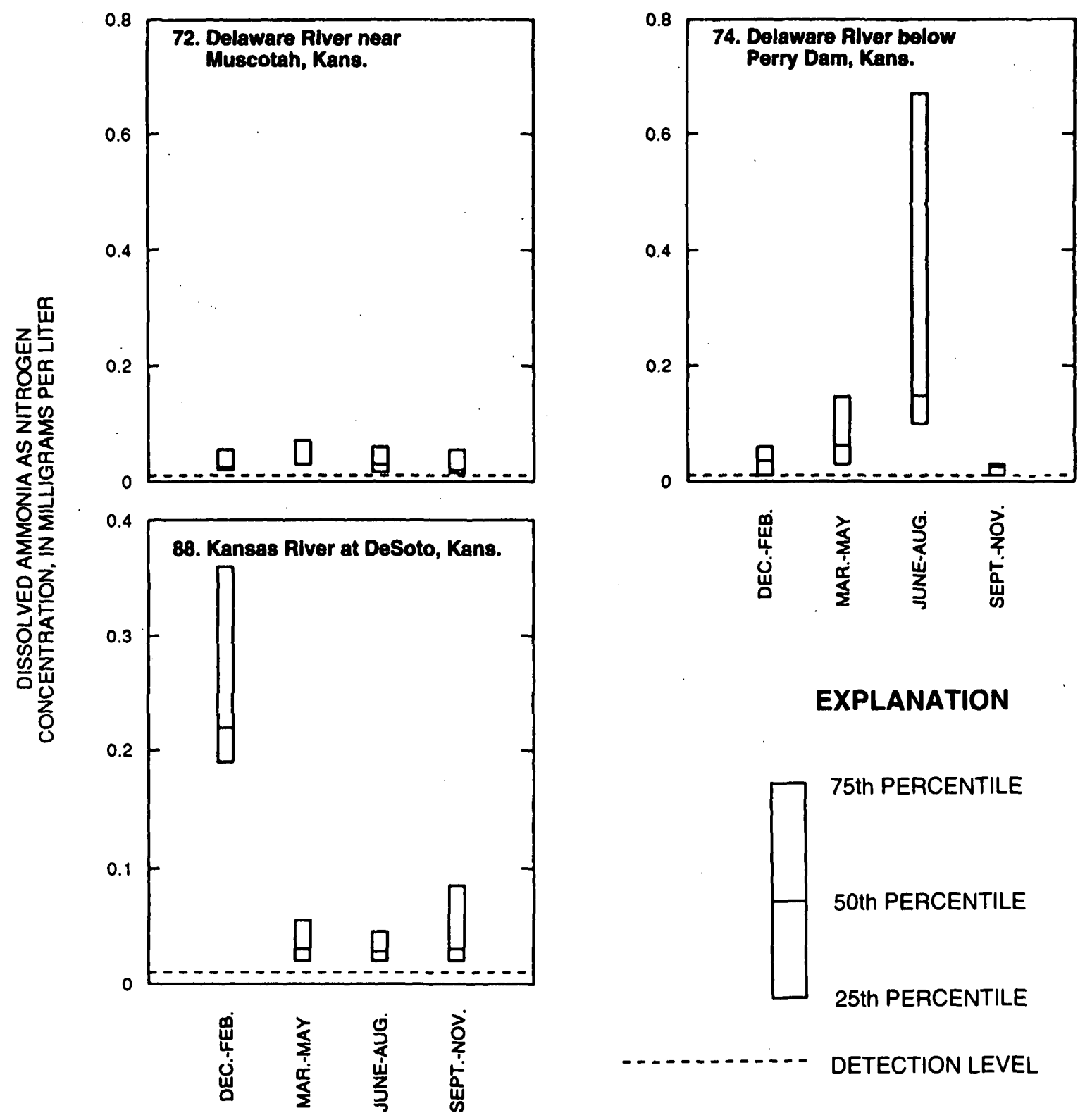

\section{EXPLANATION}

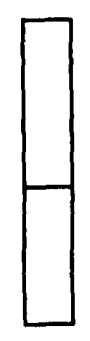

75th PERCENTILE

50th PERCENTILE

25th PERCENTILE

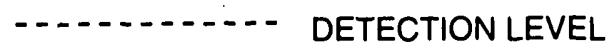

NUMBER AT TOP OF EACH GRAPH IS STATION NUMBER FROM FIGURE 9

Figure 21. Seasonal variations in concentrations of dissolved ammonia, as nitrogen, in water at selected fixed stations in lower Kansas River Basin, Kansas and Nebraska, May 1987-April 1990-Continued

reservoir probably is due to deposition and mineralization of organic nitrogen. Similarly, the mean annual yields of total ammonia plus organic nitrogen were smaller downstream from Tuttle Creek and Perry Lakes than upstream of those reservoirs.

Transport rates of total phosphorus and dissolved orthophosphate are listed in table 13. The smallest mean annual transport rate of total phosphorus was in Kings Creek near Manhattan, Kans. (station 3), 0.07 ton/yr, and the largest was in the Kansas River at DeSoto, Kans. (station 88), 1,200 ton/yr. The smallest mean annual transport rate of dissolved orthophosphate was in Kings Creek near Manhattan, Kans., less than 0.02 ton/yr, and the largest was in the Kansas River at DeSoto, Kans., 500 ton/yr. Mean annual yields of total phosphorus and dissolved orthophosphate appear to correlate with cropland distribution, being largest in the Big and Little Blue River sub- 


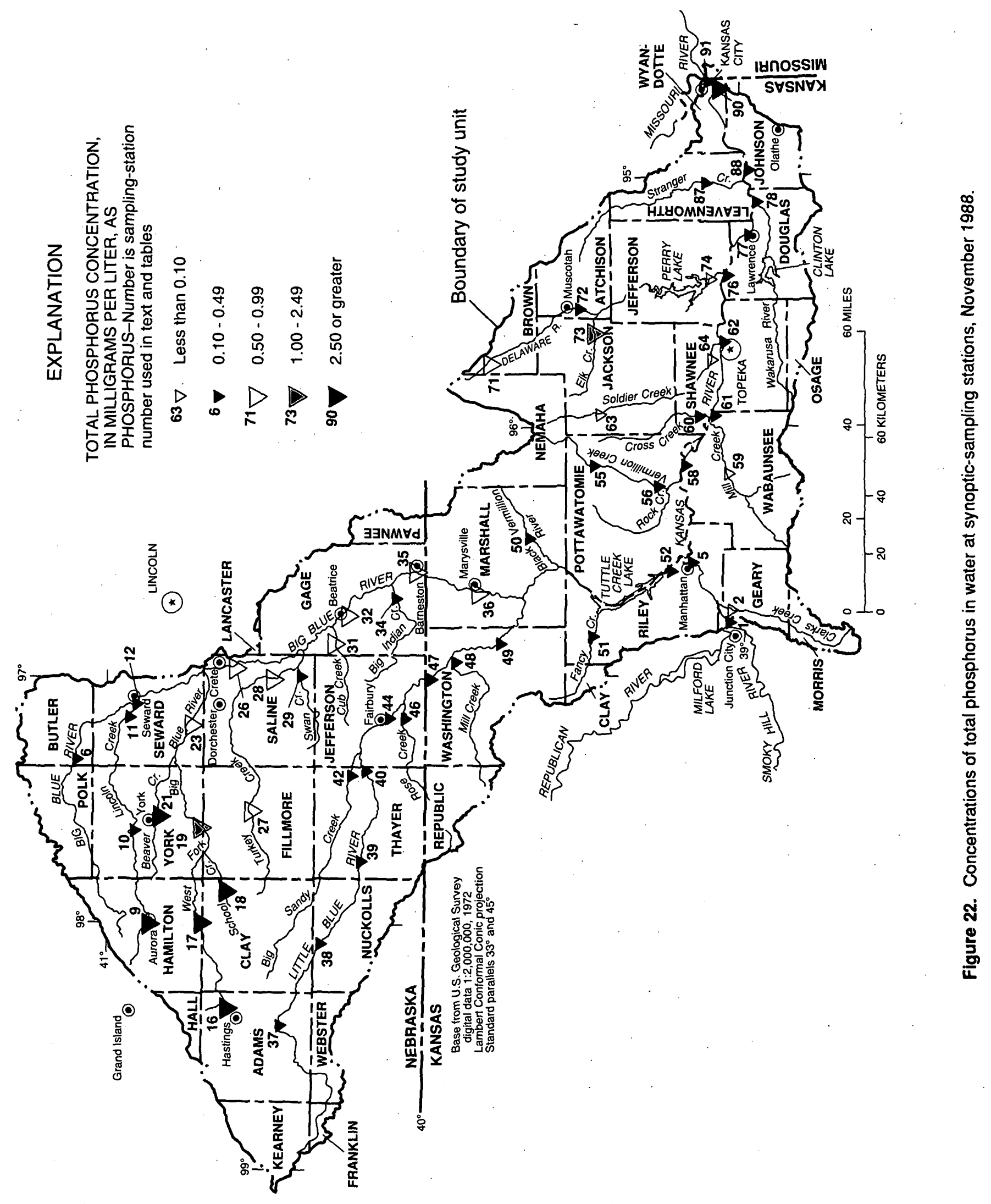

68 Surface-Water-Quality Assessment of the Lower Kansas River Basin, Kansas and Nebraska: Results of Investigations, 1987-90 

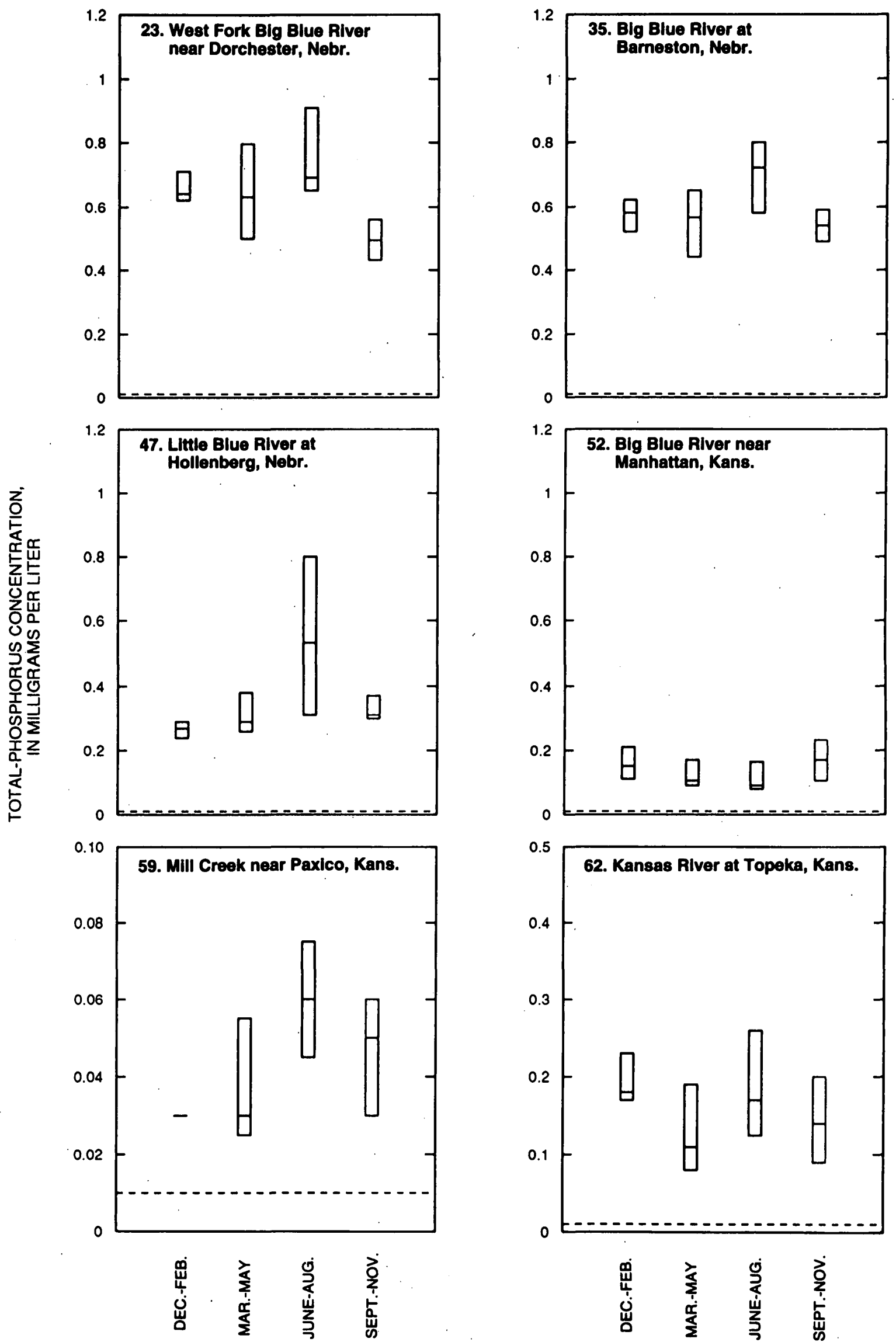

Figure 23. Seasonal variations in concentrations of total phosphorus in water at selected fixed stations in the lower Kansas River Basin, Kansas and Nebraska, May 1987-April 1990. 

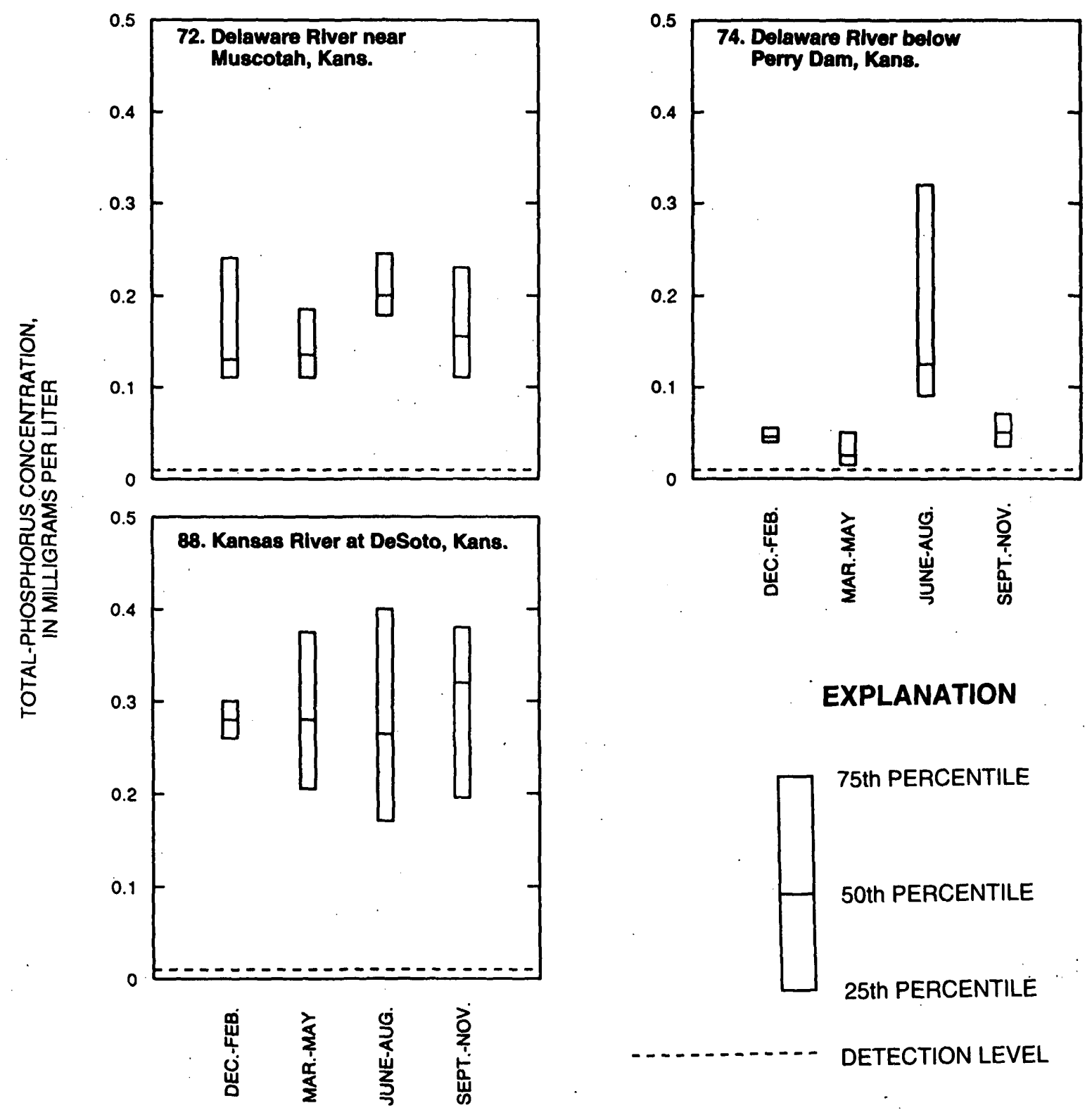

EXPLANATION

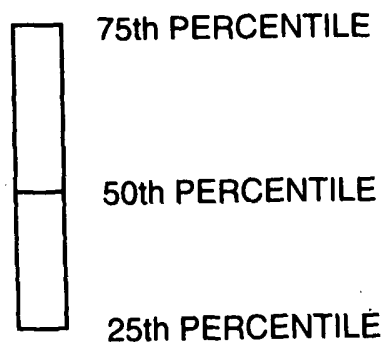

NUMBER AT TOP OF EACH GRAPH IS STATION NUMBER FROM FIGURE 9

Figure 23. Seasonal variations in concentrations of total phosphorus in water at selected fixed stations in the lower Kansas River Basin, Kansas and Nebraska, May 1987-April 1990-Continued

basins and in the Delaware River upstream of Perry Lake. Yields of total phosphorus are associated with sediment yields, which commonly are large in the relatively erodible row-crops areas. Yields of dissolved orthophosphate probably relate to phosphorus fertilizer, which is applied in the largest quantities in row-crop areas.

\section{Trends}

Nutrient data were sufficient for trend tests at six or fewer stations, depending on nutrient species. Results of trend tests are shown in table 14. 


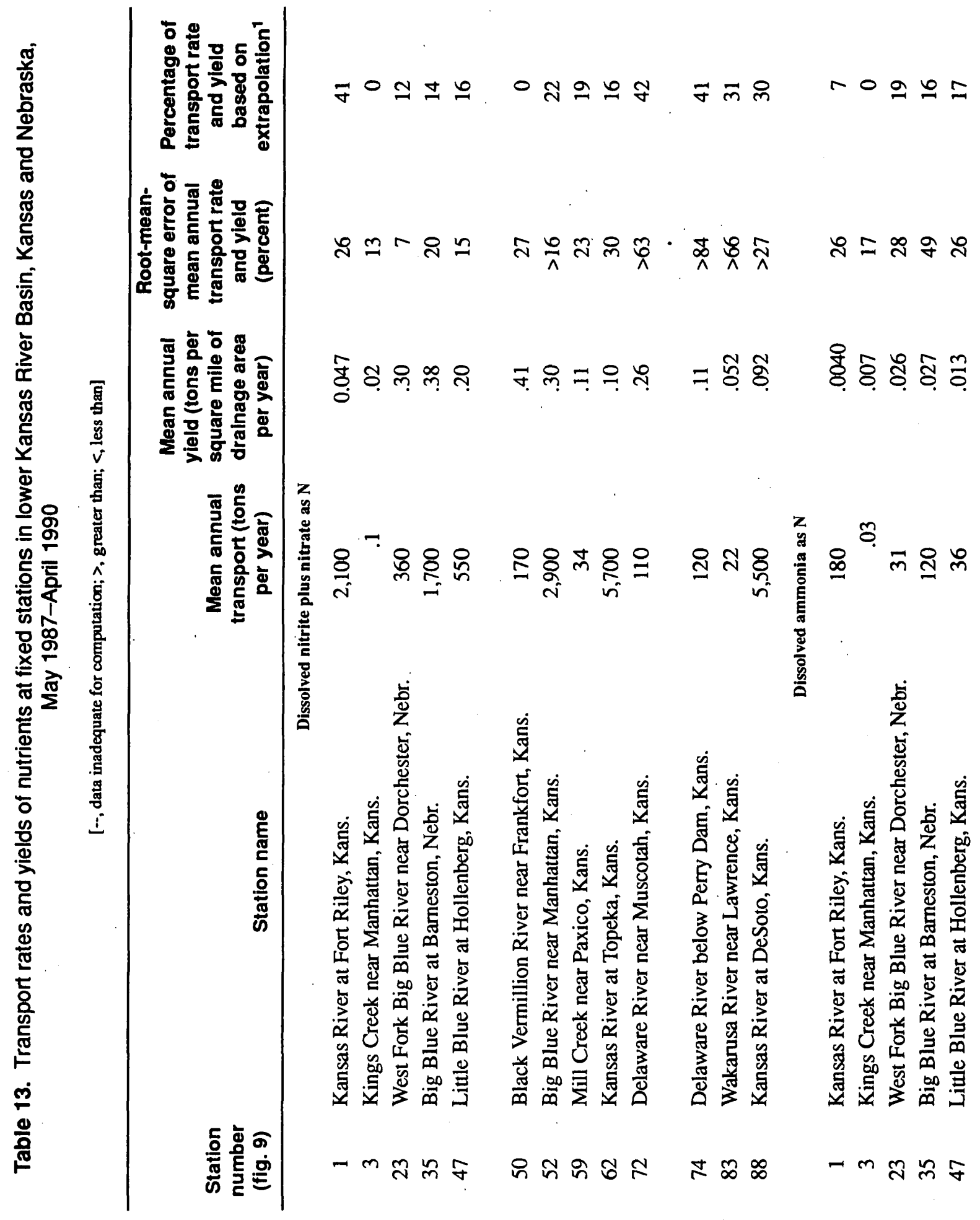




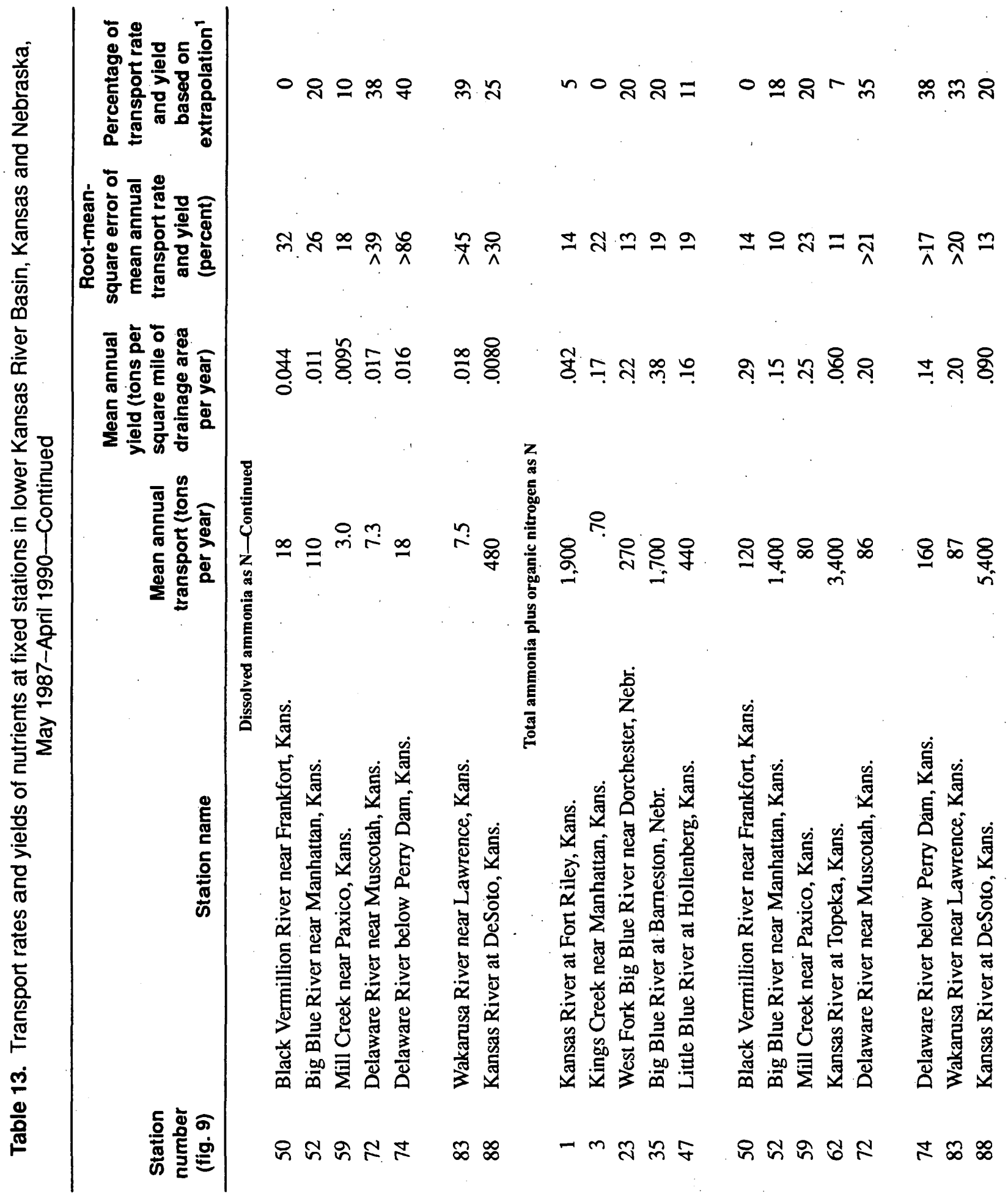




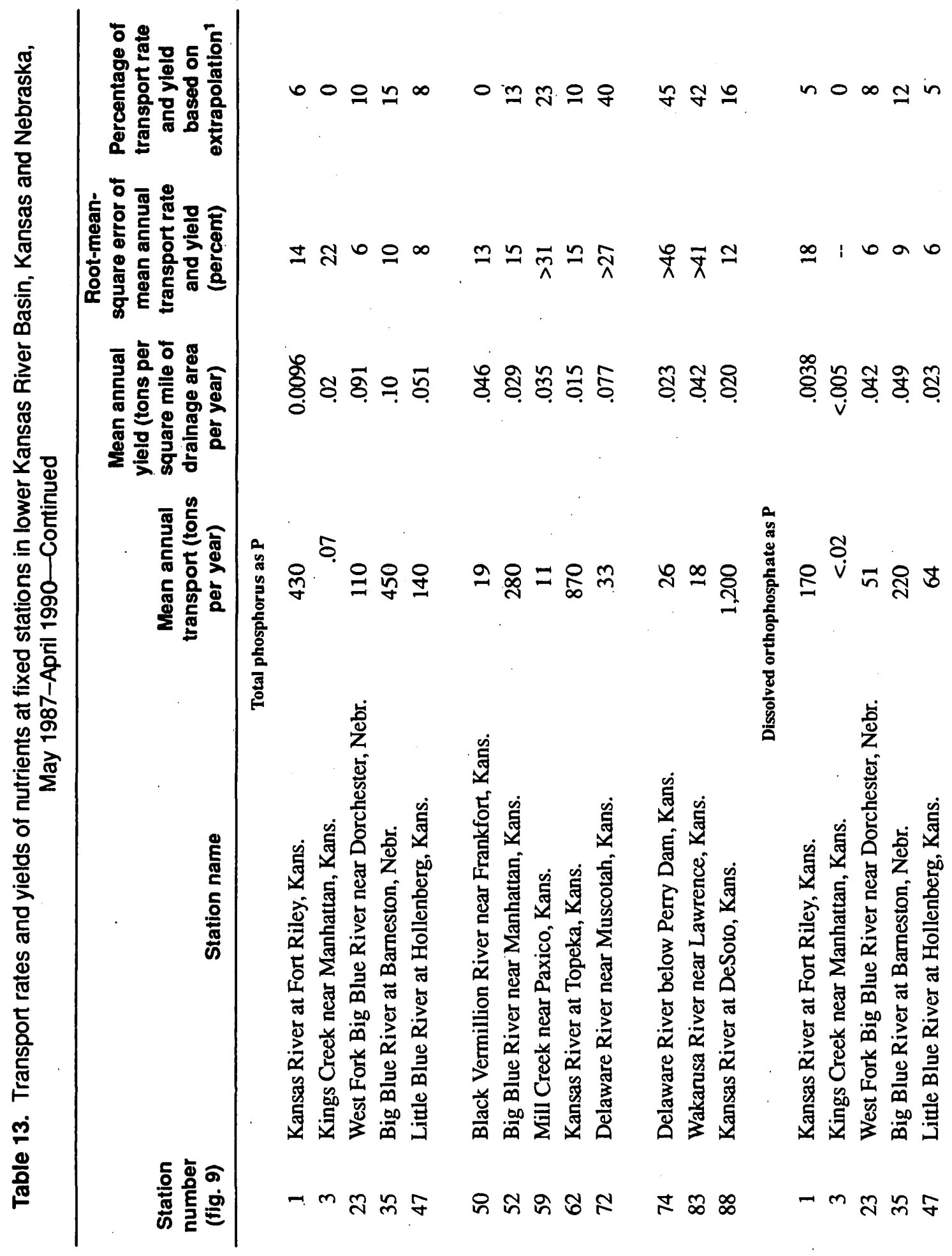




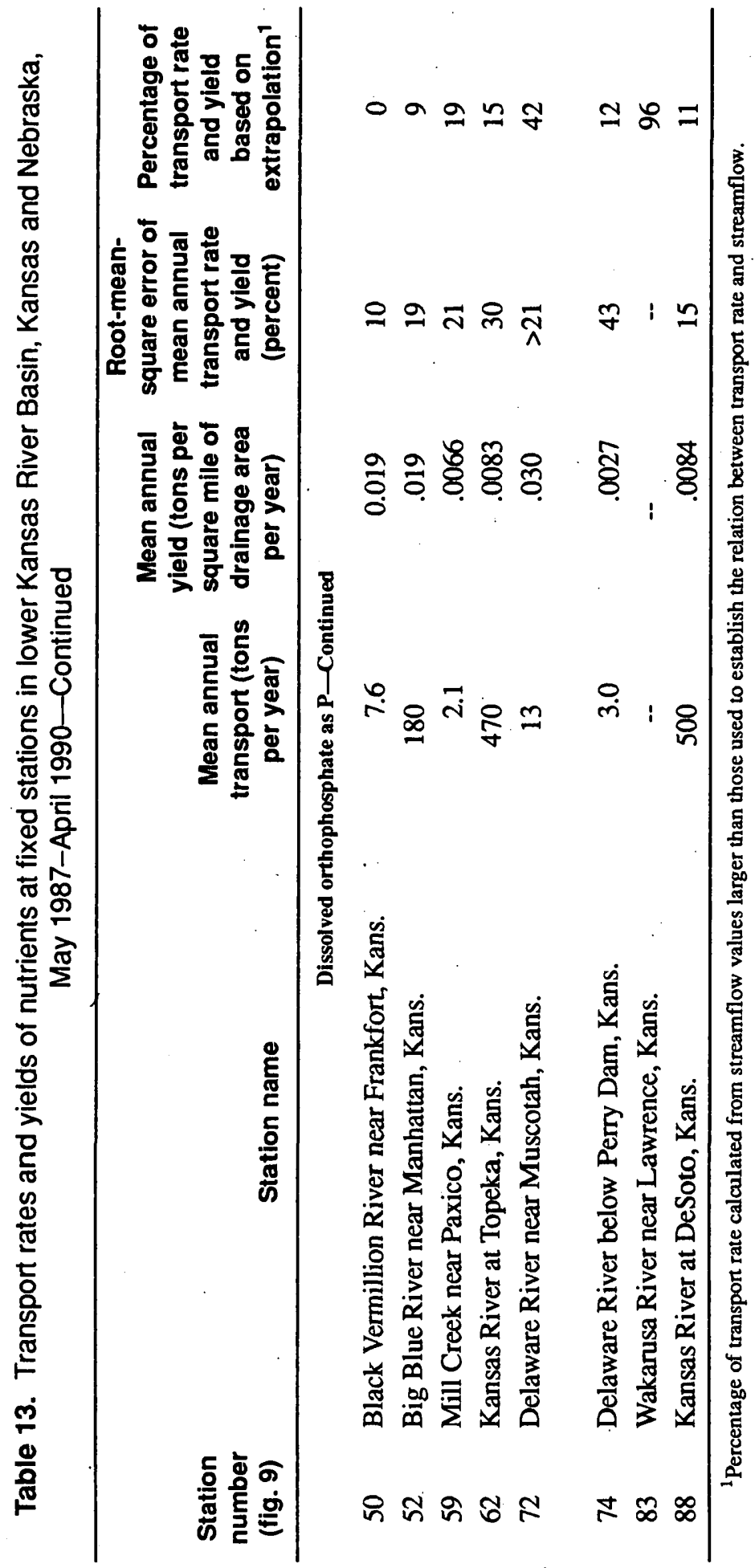

74 Surface-Water-Quality Assessment of the Lower Kansas River Basin, Kansas and Nebraska: Results of Investigations, 1987-90 


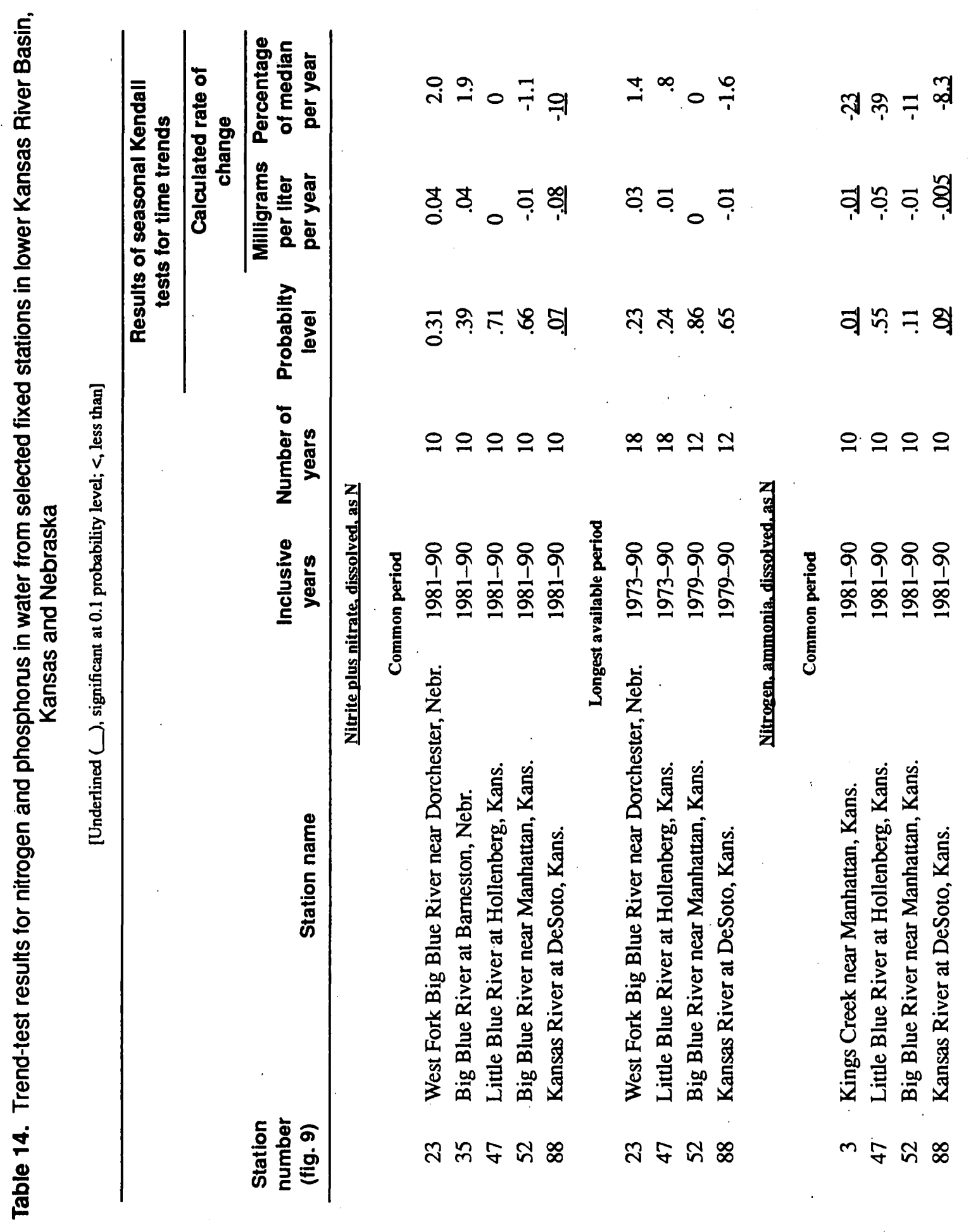




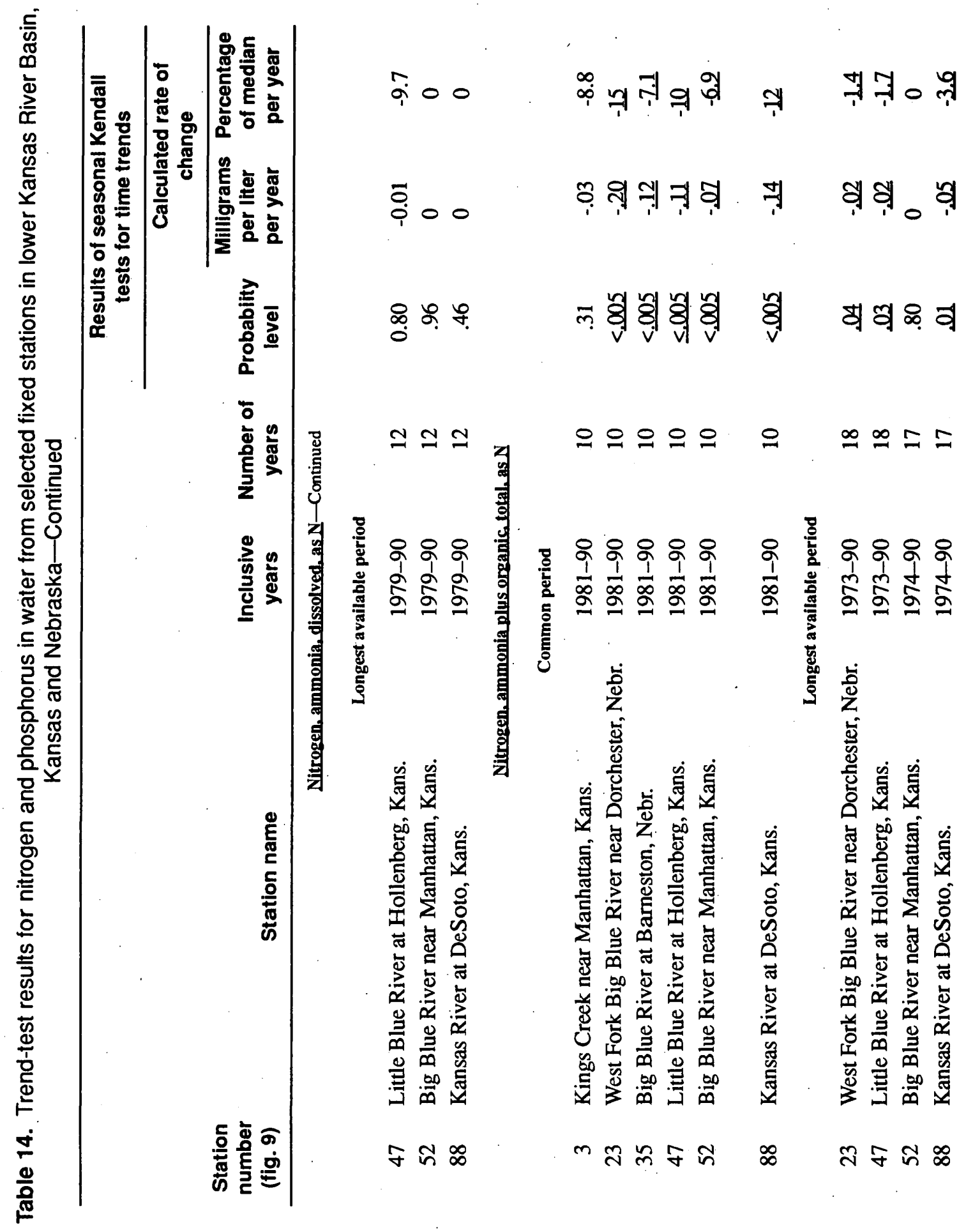




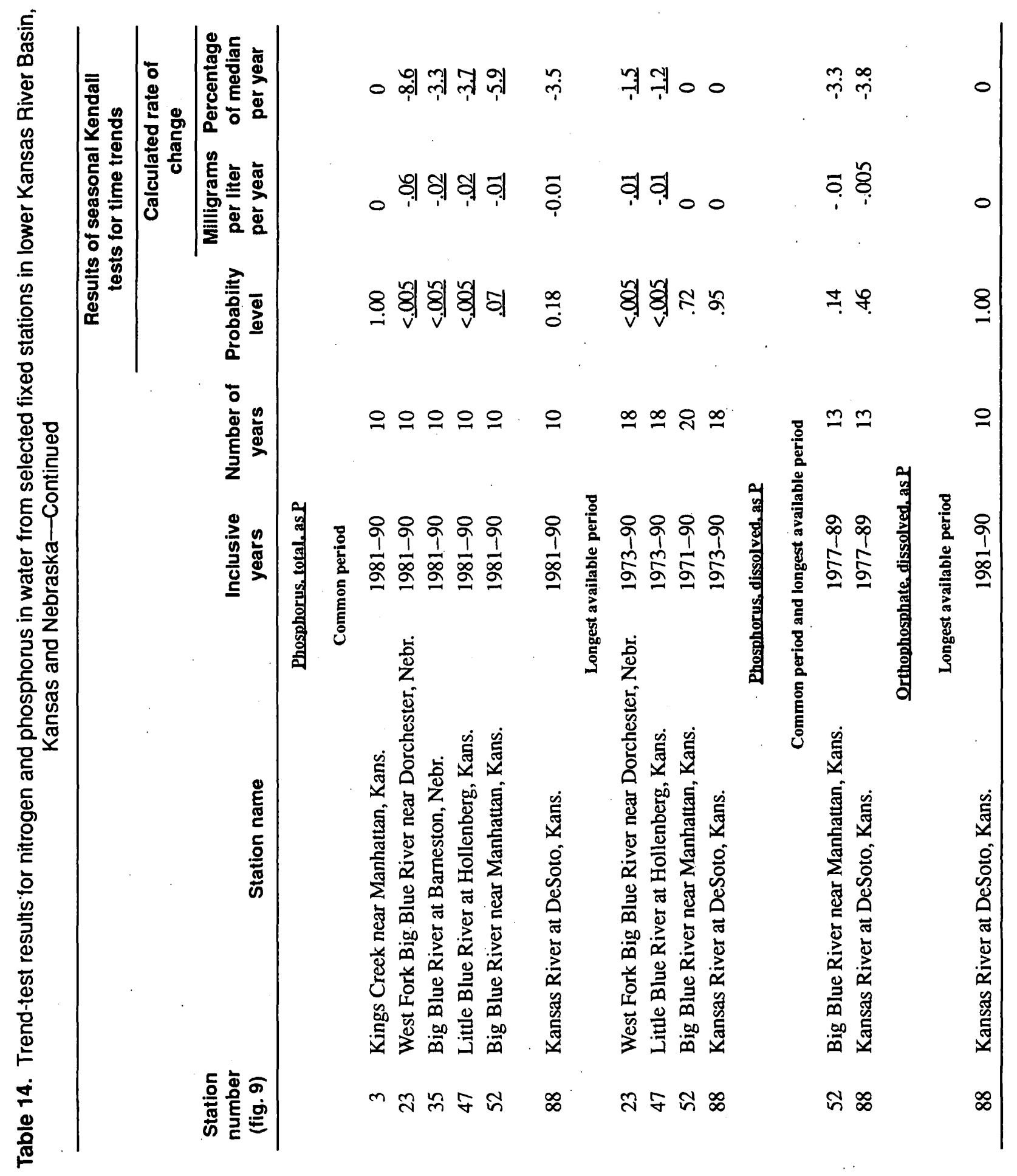


Test results for trends in concentrations of dissolved nitrate generally were not statistically significant. Stamer and Jordan (1991) found statistically significant upward trends in total nitrate concentrations during periods as long as 19 years ending in 1986. However, dissolved (not total) nitrate was analyzed in 1987-90 samples, so test results are not strictly comparable. Trend tests indicated statistically significant downward trends in concentrations of dissolved ammonia in Kings Creek near Manhattan, Kans. (station 3), and the Kansas River at DeSoto, Kans. (station 88). Concentrations of total ammonia plus organic nitrogen decreased significantly at most stations that had adequate data for computation. Trends in concentrations of these nitrogen species might be related to declines in livestock populations, changes in waste-management practices for livestock, changes in land-management practices, or changes in wastewater treatment. Data are not sufficient to establish definitive relations.

Trend tests of total phosphorus concentrations indicated that concentrations decreased significantly in the West Fork Big Blue River near Dorchester, Nebr. (station 23), the Big Blue River at Barneston, Nebr. (station 35), and the Little Blue River at Hollenberg, Kans. (station 47). Concentrations of total phosphorus in the Big Blue River near Manhattan, Kans. (station 52), also showed a statistically significant decrease during 1981-90, but showed no trend during 1971-90. Downward trends could be related to changes in landmanagement practices, but data are not sufficient to establish definitive relations. Results for dissolved phosphorus at the stations that had adequate data for computations indicated downward trends, although not statistically significant.

\section{Dissolved Oxygen and Fecal-Indicator Bacteria \\ by L.M. Pope}

Dissolved oxygen (DO) and fecal-indicator bacteria are important indicators of the sanitary quality of surface water. Adequate concentrations of DO in surface water are essential for the survival and propagation of most forms of aquatic life. Presence of fecal-indicator bacteria in water results from contamination by fecal material, and therefore, other disease-causing organisms may be present. An evaluation of the sanitary quality of water is necessary to determine its use for recreational activities, such as swimming, wading, boating, and fishing.

Primary sources of DO in streams are: (1) atmospheric oxygen dissolved in surface runoff and ground water that enter streams, (2) photosynthesis, and (3) physical aeration. Typically, ground water has very small concentrations of DO, and unless it is physically aerated, it will contribute little to the oxygen content of the receiving stream. Photosynthesis, the biochemical process of converting carbon dioxide and water into glucose and oxygen, is fueled by light energy and carried on in the cells of all algae and plants containing chlorophyll. Factors that affect the contribution of photosynthesis to the DO concentration of a stream include light intensity, turbidity, algal population, nutrient concentration, and water temperature. Physical aeration is the molecular exchange of oxygen gas directly from the atmosphere. Aeration can be a major source of DO to streams but its rate may vary among streams depending upon such factors as streamflow, turbulence, channel morphology, water temperature, and atmospheric pressure.

Consumption of DO in streams results from biochemical-oxidation reactions with carbonaceous and nitrogenous organic compounds; microbial decomposition of bottom deposits; oxidation of reduced elements such as sulfur, nitrogen, and iron; and cellular respiration. Wastewater-treatment facilities may introduce large quantities of oxygen-demanding material that may severely affect a stream that has inadequate capacity to replenish small DO concentrations. Wastewater discharges may produce a DO depression within a stream segment and result in DO concentrations that are less than acceptable water-quality criteria. The location of wastewater discharges in the study unit is shown in figure 11 .

The presence of fecal-indicator bacteria denote contamination by fecal material and the possible presence of pathogenic microorganisms. The indicator bacterium used in this study, Escherichia $\operatorname{coli}(E$. coli), is indigenous solely to the intestinal tract of warmblooded animals. It is the predominant bacterium in the fecal-coliform group 
(McKinney, 1962). The contamination indicated by the presence of $E$. coli in the aquatic environment may come from municipal-wastewater discharges; leachate from domestic septic systems, runoff or seepage from livestock-producing areas (cattle and hog production are important activities throughout the study unit), or wildlife populations.

Data on DO, bacteria, and the biological community that were available prior to this study are summarized by Stamer (1991b) and Goodman and others (1991a, 1991b). Sample collection to further define DO concentrations and $E$. coli densities in the lower Kansas River Basin was done at 61 of the 91 U.S. Geological Survey sampling stations described earlier in this report (table 4, fig. 9). These stations included the 13 fixed stations and other stations potentially significant in terms of DO and bacteria. A synoptic survey for DO and $E$. coli was conducted in July 1988 , and a followup survey for $E$. coli was conducted in July 1989. Diel studies for DO were done at some stations during the July 1988 survey and at some later times in conjunction with synoptic surveys of nutrient concentrations. Most data were collected under conditions of maximum stress to the system, such as low streamflow (less dilution of waste and smaller reaeration rates), high water temperature (smaller oxygen solubility), and maximum effect of algal respiration (usually just prior to sunrise).

\section{Dlssolved-Oxygen Concentrations}

The areal distribution of predawn instantaneous DO concentrations determined at 31 of the 77 synoptic-sampling stations during July 24-29, 1988 , is shown in figure 24 . Five of the 31 stations had instantaneous concentrations less than the $5.0-\mathrm{mg} / \mathrm{L}$ minimum warmwater criterion for early aquatic life stages established by the U.S. Environmental Protection Agency (1987). These five stations were: Lincoln Creek near Aurora, Nebr. (station 9), West Fork Big Blue River near Hastings, Nebr. (station 16), Delaware River near Fairview, Kans. (station 71), Stranger Creek at Easton, Kans. (station 86), and Turkey Creek at Kansas City, Kans. (station 90). Concentrations of DO at four of these five stations were less than the 3.0-mg/L criterion for all other life stages established by the U.S. Environmental Protection Agency (1987).
The DO deficiencies at stations 9,16 , and 90 appear to be the result of discharges of oxygendemanding material from municipal wastewatertreatment facilities that exceeded the assimilative capacities of the streams (wastewater discharges compose a substantial part of the streamflow at these sites). Concentrations of DO at these stations during subsequent synoptic surveys were similar to those measured in July 1988; some exceptions are attributable to varying streamflow conditions, water temperatures, and time of sampling (most were not predawn). Relatively large nutrient concentrations, which also may be indicative of wastewater, generally characterized samples from the same stations that had DO deficiencies (data given by Fallon and McChesney, 1993). The DO deficiency at station 71 in July 1988 probably was the result of respiratory oxygen demand by a relatively large algal and periphyton population in combination with reduced reaeration during the low flow; no other DO concentrations less than established criteria were measured during subsequent sampling at this station. Similarly, the predawn DO deficiency at station 86 probably was the result of algal respiration and inadequate physical reaeration because of extremely small streamflow.

DO concentrations measured as part of synoptic surveys during November 1988 and March and May 1989 were less than the $5.0-\mathrm{mg} / \mathrm{L}$ established criterion at the following stations: Lincoln Creek near Aurora, Nebr. (station 9), West Fork Big Blue River near Hastings, Nebr. (station 16), Beaver Creek near York, Nebr. (station 21), Cross Creek at Rossville, Kans. (station 60), Wakarusa River near Berryton, Kans. (station 79), and Wakarusa River near Lawrence, Kans. (station 83). Probable explanations for these DO deficiencies include the effects of municipal wastewater discharge, algal respiration, low streamflow, ponding as a result of beaver dams, time of sampling, and an isolated, short-duration rainfall that produced runoff containing sediment and associated oxygenconsuming materials from adjacent row-crop fields.

Concentrations of DO less than the $5.0-\mathrm{mg} / \mathrm{L}$ criterion in the study unit were localized and do not reflect regional differences in DO distribution. Most DO deficiencies were measured at only two stations (stations 9 and 16). Concentrations of DO less than the $5.0-\mathrm{mg} / \mathrm{L}$ criterion were not measured 


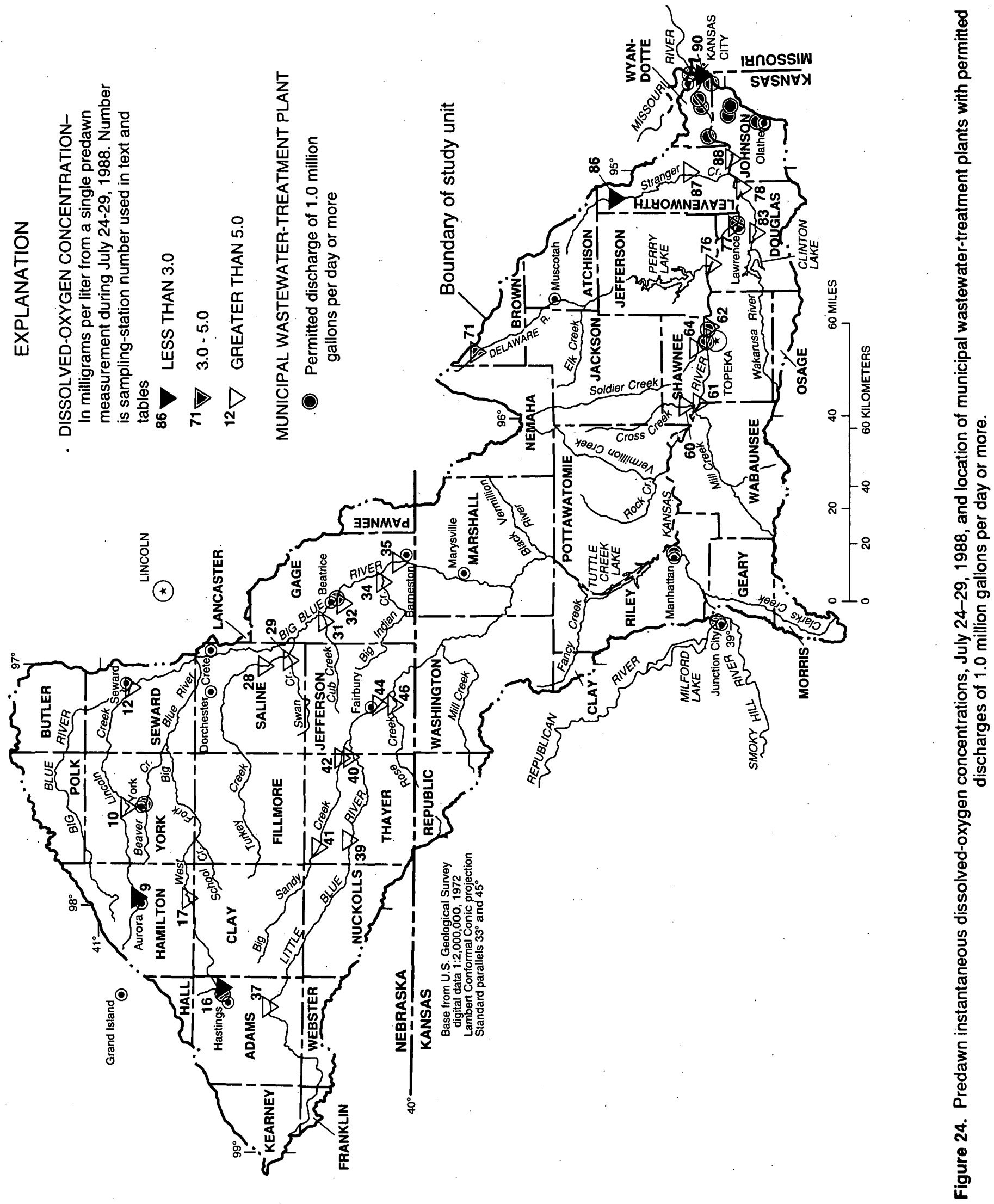

80 Surface-Water-Quality Assessment of the Lower Kansas River Basin, Kansas and Nebraska: Results of Investigations, 1987-90 
on major tributaries or the main stem of the Kansas River, and concentrations appear to be relatively similar throughout the basin. When a comparison is made of mean predawn DO concentrations on the Big Blue River (stations 12, 32, 35), Little Blue River (stations 37, 39, 40, 44) and Kansas River (stations $61,62,76,77,78,88,91$ ), there is little difference $(6.23 \mathrm{mg} / \mathrm{L}, 6.60 \mathrm{mg} / \mathrm{L}$, and $6.36 \mathrm{mg} / \mathrm{L}$, respectively).

Generally, the most serious DO deficiencies were the result of discharges from municipal wastewater-treatment facilities into small tributary streams with inadequate dilution or assimilation capacity, based on comparisons of wastewater discharge with streamflow. However, even in the absence of wastewater discharge, algal respiratory demands coupled with reduced physical reaeration during low streamflow may cause temporary, localized deficiencies in DO concentrations. Oxygen demand from the decomposition of benthic material in pooled or placid streams may serve to compound the problem during low streamflow.

Daily oxygen fluctuations and diel variability are largely dependent on temperature fluctuations and photosynthesis-respiration relations. In slow, shallow streams of the lower Kansas River Basin, which contain an abundance of phytoplankton, periphyton, and rooted aquatic plants, daytime photosynthetic production exceeds physical reaeration as a source of oxygen and obscures the effect of respiratory consumption of the gas. The result is frequent supersaturation during the day, followed by a decrease to less than 100-percent saturation at night.

Diel variability for a 24-hour period during July 1988 was determined at 11 stations in the study unit (fig. 25). At nearly every station, minimum measured DO concentrations occurred just before dawn (about 0600 hours), and maximum measured concentrations occurred during late afternoon-early evening (about 1800 hours). Concentrations of DO less than the $5.0-\mathrm{mg} / \mathrm{L}$ criterion were not observed at any of the diel-study stations. The largest DO concentrations were determined at Little Blue River near Fairbury, Nebr., station $44(10.6 \mathrm{mg} / \mathrm{L})$, and Kansas River at Lecompton, Kans., station 76 (11.4 mg/L). The largest range in DO concentrations also occurred at these two stations $(5.3 \mathrm{mg} / \mathrm{L}$ and $5.6 \mathrm{mg} / \mathrm{L}$, respectively).

Diel variations commonly displayed evidence of supersaturation during the daytime hours and a saturation deficit during the night. Maximum percentages of DO saturation at all 11 stations ranged from 94 percent at station 46 to 157 percent at station 76 , with a mean maximum percentage of saturation of 115 percent. Minimum percentages of DO saturation ranged from 66 percent at station 12 to 79 percent at station 34 , with a mean minimum percentage of saturation of 72 percent. The mean percentage of DO saturation using all measurements at all stations was 92 percent. It appears that diel variations in streams in the study unit, not affected by the localized problems previously discussed, are basically a function of the photosynthesis-respiration relation and, to a lesser extent for any short-term period, temperature and atmospheric pressure.

Seasonally induced variation in diel variability was examined at station 32, Big Blue River at Beatrice, Nebr., and at station 76, Kansas River at Lecompton, Kans. Diel studies were conducted at both stations in July and November 1988 and March 1989, and at station 32 in May 1989. Comparisons of results from the seasons demonstrate the effect of water temperature on oxygen solubility. As water temperature decreased, DO concentrations increased, and diel variability generally decreased.

\section{Fecal Coliform Densities}

Generally, there are large regional differences in $E$. coli densities within the study unit, as evidenced by the results of sampling at 57 of the 77 synoptic stations in July 1988 (fig. 26). Densities of E. coli in water at the 19 stations in the Big Blue River subbasin, exclusive of the Little Blue River subbasin, upstream of Tuttle Creek Lake (stations $6-36,50$, and 51), ranged from $120 \mathrm{col} / 100 \mathrm{~mL}$ in Fancy Creek at Winkler, Kans. (station 51), to $260,000 \mathrm{col} / 100 \mathrm{~mL}$ in the West Fork Big Blue River near Hastings, Nebr. (station 16). Densities at the 11 stations in the Little Blue River subbasin (stations 37-49) ranged from $100 \mathrm{col} / 100 \mathrm{~mL}$ in the Little Blue River near Alexandria, Nebr. (station 40), to $30,000 \mathrm{col} / 100 \mathrm{~mL}$ in Big Sandy Creek near Davenport, Nebr. (station 41). Densities 


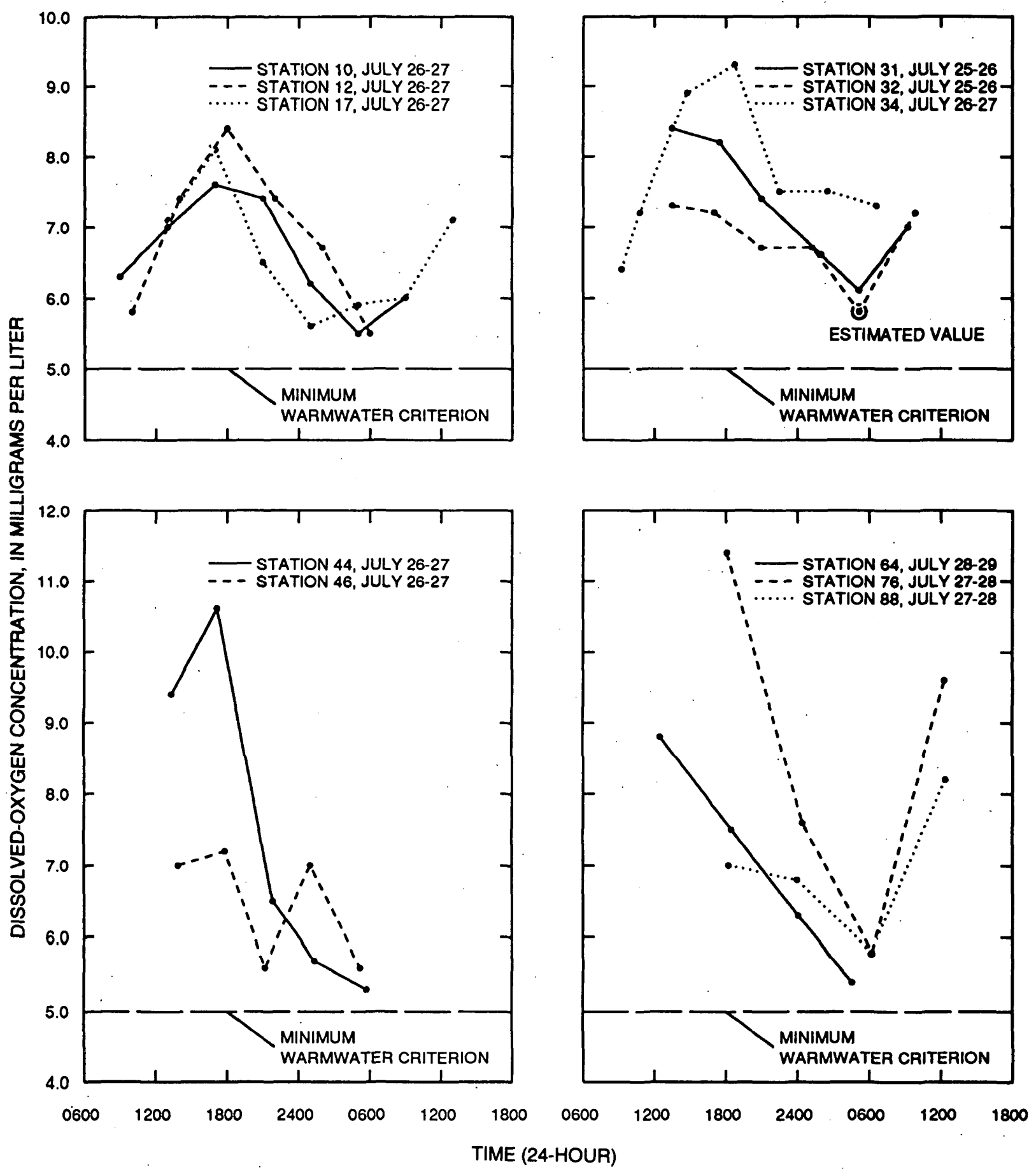

Figure 25. Diel variability of dissolved-oxygen concentrations in water at selected synoptic-sampling stations in lower Kansas River Basin, Kansas and Nebraska, July 24-29, 1988 (criterion established by U.S. Environmental Protection Agency, 1987).

82 Surface-Water-Quality Assessment of the Lower Kansas River Basin, Kansas and Nebraska: Results of Investigations, $1987-90$ 


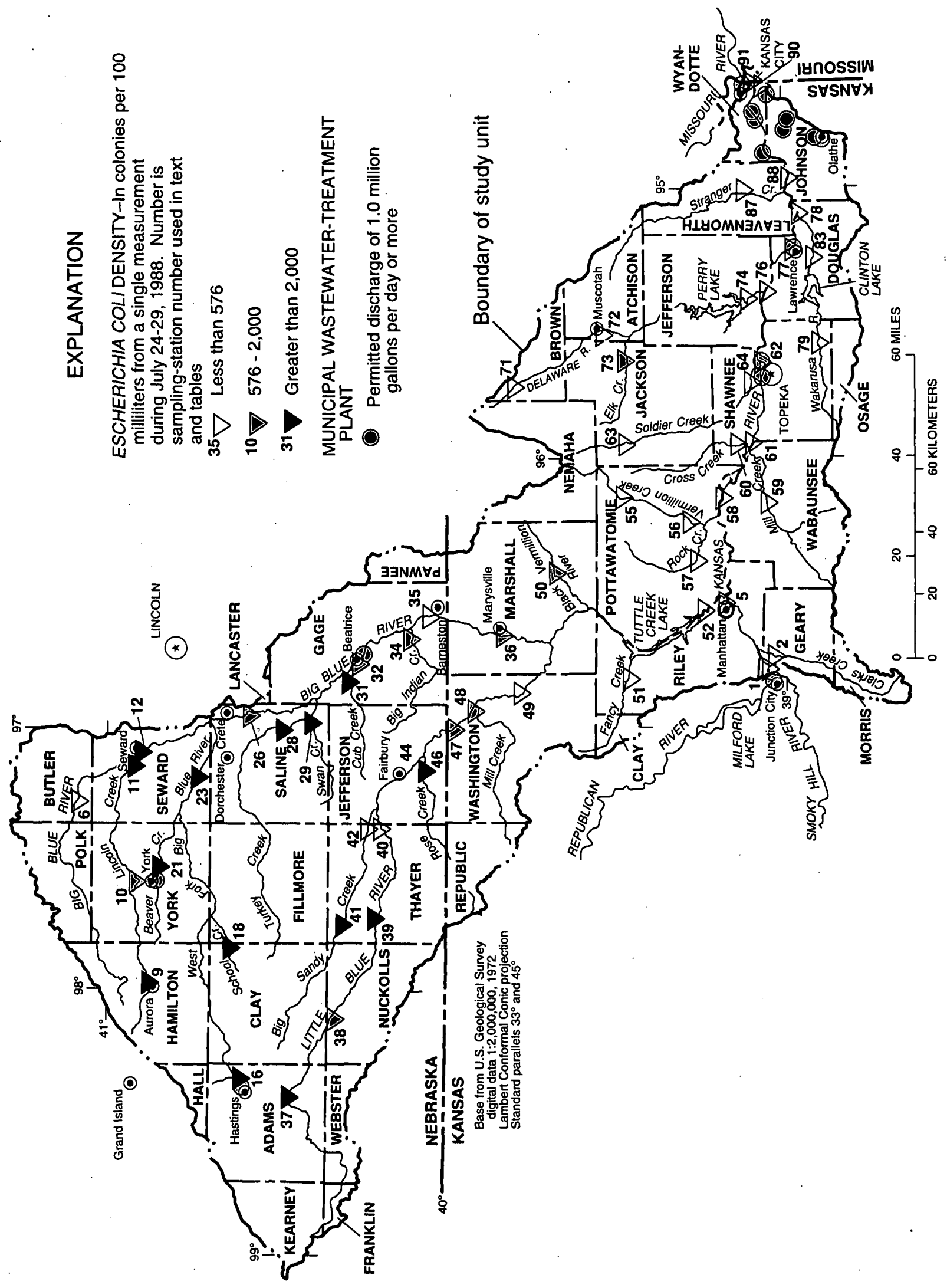

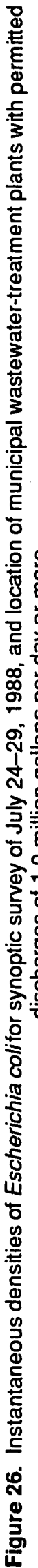


of $E$. coli at the 27 stations located in the Kansas River subbasin (stations 1, 2, 5, and 52-91) ranged from less than $1 \mathrm{col} / 100 \mathrm{~mL}$ in the Delaware River below Perry Dam, Kans. (station 74), to 1,000 col/100 mL at Elk Creek near Larkinburg, Kans. (station 73). A comparison of $E$. coli densities (25th, 50th, and 75th percentiles) determined in samples from the Big Blue River, Little Blue River, and Kansas River subbasins is shown in figure 27.

Of the 19 stations sampled in the Big Blue River subbasin upstream of Tuttle Creek Lake, stream water at 16 (84 percent) of those stations exceeded the U.S: Environmental Protection Agency (1987) criterion for $E$. coli densities $(576 \mathrm{col} / 100 \mathrm{~mL})$ for infrequently used full-body contact recreation, and 10 stations (53 percent) exceeded the 2,000-col/100 mL fecal coliform criterion for uses other than full-body contact established by the Kansas Department of Health and Environment (Fromm and Wilk, 1988). Of the 11 stations sampled for $E$. coli in the Little Blue River subbasin, water at 8 stations ( 73 percent) exceeded the $576-\mathrm{col} / 100 \mathrm{~mL}$ full-body contact criterion, and water at 4 stations ( 36 percent)

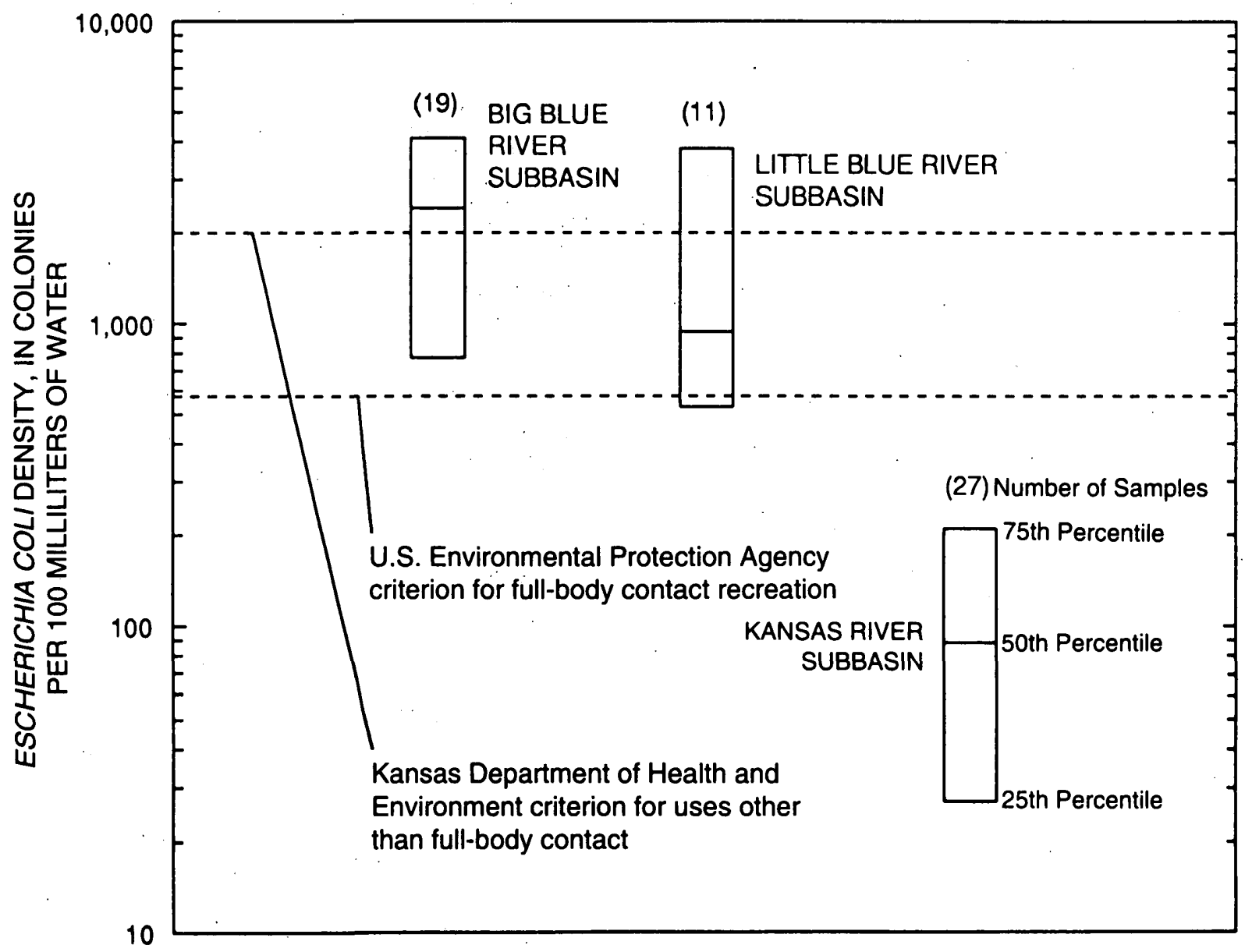

Figure 27. Densities of Escherichia coli in the Big Blue River, Little Blue River; and Kansas River subbasins in lower Kansas River Basin, Kansas and Nebraska, for synoptic survey of July 24-29, 1988 [water-quality criteria established by the U.S. Environmental Protection Agency (1987) and Kansas Department of Health and Environment (Fromm and Wilk, 1988)]. 
exceeded the 2,000-col/100 mL criterion for other than full-body contact. Of the 27 stations sampled for $E$. coli in the Kansas River subbasin, water at only 1 station (4 percent), Elk Creek near Larkinburg, Kans. (station 73), a tributary to the Delaware River, exceeded the $576-\mathrm{col} / 100 \mathrm{~mL}$ criterion for full-body contact; that density $(1,000 \mathrm{col} / 100 \mathrm{~mL})$ did not exceed the 2,000-col/100 mL criterion for other than full-body contact.

Point-source discharges from municipal wastewater-treatment plants (fig. 11) have a substantial effect on $E$. coli densities at several of the stations in the Big Blue River and Little Blue River subbasins. During the times that the synoptic surveys were conducted for this study, none of the wastewater-treatment plants in the study unit disinfected (that is, chlorinated) effluent before it was discharged into receiving streams. The drainage area of each sampling station in these subbasins contained at least one treatment plant; however, most of these plants serve small communities and typically have permitted-discharge rates of less than $0.10 \mathrm{Mgal} / \mathrm{d}$. Therefore, their potential effect may be limited to stations within several stream miles of the discharge point and may have only minimal effect at stations farther downstream. The effect of larger facilities, greater than $1.0 \mathrm{Mgal} / \mathrm{d}$, is most evident in the West Fork Big Blue River near Hastings, Nebr. (station 16), where an $E$. coli density of $260,000 \mathrm{col} / 100 \mathrm{~mL}$ was determined. Water at this station also was characterized by DO concentrations less than minimum criteria and by large nutrient concentrations. Streams in the Big Blue River and Little Blue River subbasins that appear to have $E$. coli densities affected by close proximity to pointsource discharges include Lincoln Creek near Aurora, Nebr. (station 9); School Creek near Sutton, Nebr. (station 18); Beaver Creek near York, Nebr. (station 21); Big Blue River near Crete, Nebr. (station 26); Cub Creek near Beatrice, Nebr. (station 31); Big Sandy Creek near Davenport, Nebr. (station 41); and Little Blue River near Fairbury, Nebr. (station 44).

Although point-source discharges may be responsible for large $E$. coli densities at specific stations during base-flow conditions and may contribute to conditions at stations farther downstream, it appears that additional factors may be responsible for $E$. coli densities that generally were larger in the Big Blue River and Little Blue River subbasins than those in the Kansas River subbasin. The Kansas River subbasin also contains many wastewater-treatment plants with large and small permitted discharges located on large and small streams, similar to the situation in the Big Blue River and Little. Blue River subbasins. With only one exception, $E$. coli densities in the Kansas River subbasin were less than maximum densities permitted by water-quality criteria. The most likely source of the large $E$. coli densities in the Big Blue River and Little Blue River subbasins is fecal material from domestic livestock in pastures or confined feedlots. The effect of livestock production also has been indicated by large fecal streptococci densities reported for Lincoln Creek near Seward, Nebr. (station 11) (Goodman and others, 1991a).

In July 1989, 36 of the 57 stations sampled during July 1988 were resampled in an attempt to verify the distributional pattern and magnitude of E. coli densities observed in July 1988 . However, comparisons of results were complicated by dissimilar hydrologic conditions during the two sampling periods. Most streams were affected by overland runoff from recent rain during the July 1989 sampling period. Densities of $E$. coli determined in July 1989 generally were larger than those in July 1988 and ranged from $5 \mathrm{col} / 100 \mathrm{~mL}$ in the Delaware River below Perry Dam, Kans. (station 74), to $790,000 \mathrm{col} / 100 \mathrm{~mL}$ at West Fork Big Blue River near Hastings, Nebr. (station 16). Water samples from these two stations also had the minimum and maximum densities, respectively, of all stations sampled in July 1988. The larger densities determined in July 1989 appear to be the result of nonpoint-source contamination from overland runoff during the previous 3 to 14 days. The largest densities in July 1989 were in the Big Blue and Little Blue River subbasins, a situation similar to that observed in July 1988.

\section{Metals and Trace Elements by D.Q. Tanner, R.B. Zelt, and J.L. Ryder}

Some metals and most trace elements are essential to animal and plant nutrition, but they can be toxic in large quantities. Metals and trace 
elements in the aquatic environment can result from human activities, such as the burning of fossil fuel, automobile emissions, and various industries. The ecological importance of metals and trace elements in water is addressed by the U.S. Environmental Protection Agency, which has established certain MCL's for public-water supplies and freshwater-aquatic criteria for fish tissue.

Metals and trace elements occur in several different states or phases in surface-water systems. They may be in aqueous solution (dissolved phases). Metals and trace elements forming the matrix of, or adsorbed to, suspended-sediment particles comprise the suspended phase. The sediment particles may be deposited on the streambed but may become re-suspended or dissolved at a later time. Streambed sediment typically contains relatively large concentrations of some metals and trace elements. Finally, these constituents may be incorporated into biota, including fish tissue, in the aquatic environment.

Data on metals and trace elements that were available prior to this study were summarized by Ryder and Sanzolone (1989) and Stamer and others (1991). Additional data on metals and trace elements in the dissolved and suspended phases were determined for samples collected at the 13 fixed stations (table 4, fig. 9) during May 1987 through April 1990. Samples for streambedsediment analyses were collected at 422 sites on first- and second-order streams during September and October of 1987 and at 62 of the 77 synoptic stations (table 4, fig. 9) during October 1987. Details on methods and data are given by Tanner and others (1990). State agencies (Kansas Department of Health and Environment and Nebraska Department of Environmental Quality) collected 34 fish samples for trace-element analysis at 12 stations during May 1987 through April 1990 as part of the U.S. Environmental Protection Agency's Regional Ambient Fish Tissue Monitoring Program (RAFTMP). Descriptions of the RAFTMP are presented by Cringan (1989, 1991) and Callam and others (1990). Fish-tissue samples were collected from stations 47,77 , and 92-101 (table 4).

\section{Dissolved Concentrations and Trends}

A statistical summary of dissolved concentrations for some metals and trace elements during May 1987 through April 1990 is presented in table 15. Most of the metals and trace elements were present only in small concentrations in the dissolved phase. Concentrations of several elements are not reported or discussed because they were generally less than detection levels. Also, results are not presented for eight elements (arsenic, beryllium, cadmium, chromium, copper, lead, mercury, and zinc) because of possible contamination during sample collection and processing in the field.

Patterns of distribution were not apparent for most metals and trace elements. However, the largest median concentrations of dissolved lithium were at the three fixed stations on the Kansas River (stations 1, 62, and 88), and the median concentration decreased in the downstream direction (fig. 28). Lithium concentrations in the Kansas River probably are due largely to saline groundwater discharge to the Smoky Hill River upstream of the study unit, which was described by Gillespie and Hargadine (1981). Decreasing median concentrations of lithium between Fort Riley (station 1) and DeSoto (station 88) probably result from dilution as other streams flow into the Kansas River. The relation between dissolved-lithium concentrations and streamflow of the Kansas River at Fort Riley (station 1) also suggests a groundwater source of lithium. As streamflow increased at Fort Riley, the concentration of dissolved lithium decreased; large streamflows are associated with precipitation and runoff; which would tend to dilute the concentrations of lithium contributed by saline ground-water discharge. Strontium probably also is a component of ground-water discharge to the Smoky Hill River, and concentrations of dissolved strontium in the Kansas River were similar to those of lithium.

Data were sufficient for trend tests for dissolved iron and manganese at some stations and for periods as long as 28 years. Trend-test results (table 16) indicate statistically significant downward trends of iron and manganese concentrations at many stations. These trends generally are consistent with the upward trend in $\mathrm{pH}$ described in the "Other Water-Quality Characteristics" section 
Table 15. Statistical summary of concentrations of selected dissolved metals and trace elements in water from fixed stations in lower Kansas River Basin, Kansas and Nebraska, May 1987-April 1990

[Concentrations in micrograms per liter, $\cdots$, the 10- and 90-percentile values are not shown for sampling stations having fewer than 30 analyses; $<$, less than]

\begin{tabular}{|c|c|c|c|c|c|c|c|}
\hline \multirow[b]{2}{*}{$\begin{array}{c}\text { Station } \\
\text { number } \\
\text { (fig. 9) }\end{array}$} & \multirow[b]{2}{*}{ Station name } & \multirow[b]{2}{*}{$\begin{array}{c}\text { Number } \\
\text { of } \\
\text { analyses }\end{array}$} & \multicolumn{5}{|c|}{ Concentration at indicated percentile } \\
\hline & & & 10 & 25 & $\begin{array}{c}50 \text { (me- } \\
\text { dian) }\end{array}$ & 75 & 90 \\
\hline
\end{tabular}

Aluminum, dissolved

$\begin{array}{llrrrrrr}23 & \text { West Fork Big Blue River near Dorchester, Nebr. } & 32 & <10 & <10 & 10 & 28 & 140 \\ 35 & \text { Big Blue River at Barneston, Nebr. } & 34 & <10 & <10 & <10 & 20 & 170 \\ 47 & \text { Little Blue River at Hollenberg, Kans. } & 30 & <10 & <10 & 10 & 20 & 210 \\ 50 & \text { Black Vermillion River near Frankfort, Kans. } & 12 & -- & <10 & 15 & 140 & -- \\ 59 & \text { Mill Creek near Paxico, Kans. } & 10 & -- & <10 & <10 & 12 & - \\ & & & & & & \\ 62 & \text { Kansas River at Topeka, Kans. } & 10 & -- & <10 & 15 & 48 & - \\ 72 & \text { Delaware River near Muscotah, Kans. } & 35 & <10 & <10 & 40 & 100 & 230 \\ 74 & \text { Delaware River below Perry Dam, Kans. } & 33 & <10 & <10 & <10 & 65 & 170 \\ 83 & \text { Wakarusa River near Lawrence, Kans. } & 34 & <10 & <10 & <10 & 42 & 120\end{array}$

Barium, dissolved

1 Kansas River at Fort Riley, Kans. 38

3 Kings Creek near Manhattan, Kans.

23 West Fork Big Blue River near Dorchester, Nebr.

35 Big Blue River at Barneston, Nebr.

47 Little Blue River at Hollenberg, Kans.

50 Black Vermillion River near Frankfort. Kans.

52 Big Blue River near Manhattan, Kans.

59 Mill Creek near Paxico, Kans.

62 Kansas River at Topeka, Kans.

72. Delaware River near Muscotah, Kans.

74 Delaware River below Perry Dam, Kans.

83 Wakarusa River near Lawrence, Kans.

88 Kansas River at DeSoto, Kans.

$\begin{array}{rrrrrr}38 & 98 & 120 & 130 & 140 & 150 \\ 23 & -- & 80 & 110 & 110 & -- \\ 43 & 71 & 140 & 160 & 170 & 190 \\ 40 & 88 & 110 & 140 & 150 & 170 \\ 39 & 84 & 130 & 150 & 160 & 190 \\ & & & & & \\ 41 & 89 & 130 & 160 & 170 & 190 \\ 36 & 110 & 120 & 130 & 140 & 150 \\ 39 & 76 & 110 & 130 & 150 & 160 \\ 36 & 100 & 110 & 130 & 140 & 160 \\ 34 & 96 & 130 & 160 & 190 & 230 \\ & & & & & \\ 32 & 74 & 82 & 100 & 120 & 150 \\ 28 & -- & 70 & 80 & 85 & -- \\ 38 & 97 & 110 & 20 & 140 & 150\end{array}$


Table 15. Statistical summary of concentrations of selected dissolved metals and trace elements in water from fixed stations in lower Kansas River Basin, Kansas and Nebraska, May 1987-April 1990-Continued

\begin{tabular}{|c|c|c|c|c|c|c|c|}
\hline \multirow[b]{2}{*}{$\begin{array}{c}\text { Station } \\
\text { number } \\
\text { (fig. 9) }\end{array}$} & \multirow[b]{2}{*}{ Station name } & \multirow[b]{2}{*}{$\begin{array}{c}\text { Number } \\
\text { of } \\
\text { analyses }\end{array}$} & \multicolumn{5}{|c|}{ Concentration at indicated percentlle } \\
\hline & & & 10 & 25 & $\begin{array}{l}50 \text { (me- } \\
\text { dlan) }\end{array}$ & 75 & 90 \\
\hline \multicolumn{8}{|c|}{ Boron, dissolved } \\
\hline 1 & Kansas River at Fort Riley, Kans. & 10 & - & 90 & 120 & 120 & -. \\
\hline 23 & West Fork Big Blue River near Dorchester, Nebr. & 14 & -- & 35 & 50 & 60 & -- \\
\hline 35 & Big Blue River at Barneston, Nebr. & 11 & -- & 30 & 40 & 60 & -- \\
\hline 47 & Little Blue River at Hollenberg, Kans. & 13 & -- & 40 & 50 & 55 & -- \\
\hline 50 & Black Vermillion River near Frankfort, Kans. & 12 & -- & 32 & 50 & 50 & -- \\
\hline 59 & Mill Creek near Paxico, Kans. & 10 & -- & 30 & 50 & 60 & -- \\
\hline 62 & Kansas River at Topeka, Kans. & 10 & -- & 68 & 80 & 92 & -- \\
\hline 72 & Delaware River near Muscotah, Kans. & 35 & 30 & 80 & 110 & 160 & 200 \\
\hline 74 & Delaware River below Perry Dam, Kans. & 33 & $<20$ & 30 & 60 & 95 & 130 \\
\hline 83 & Wakarușa River near Lawrence, Kans. & 34 & $<10$ & 20 & 70 & 90 & 140 \\
\hline \multicolumn{8}{|c|}{ Iron, dissolved } \\
\hline 1 & Kansas River at Fort Riley, Kans. & 38 & $<3$ & 4 & 8 & 11 & 32 \\
\hline 3 & Kings Creek near Manhattan, Kans. & 22 & -- & $<3$ & 5 & 13 & -- \\
\hline 23 & West Fork Big Blue River near Dorchester, Nebr. & 43 & 5 & 8 & 11 & 42 & 170 \\
\hline 35 & Big Blue River at Barneston, Nebr. & 40 & 5 & 6 & 10 & 14 & 35 \\
\hline 47 & Little Blue River at Hollenberg, Kans. & 39 & 5 & 7 & 12 & 18 & 110 \\
\hline 50 & Black Vermillion River near Frankfort, Kans. & 41 & 3 & 6 & 11 & 26 & 79 \\
\hline 52 & Big Blue River near Manhattan, Kans. & 36 & $<3$ & 5 & 8 & 10 & 24 \\
\hline 59 & Mill Creek near Paxico, Kans. & 39 & $<3$ & 4 & 6 & 10 & 19 \\
\hline 62 & Kansas River at Topeka, Kans. & 36 & 3 & 5 & 9 & 16 & 75 \\
\hline 72 & Delaware River near Muscotah, Kans. & 20 & -- & $<10$ & 13 & 18 & -- \\
\hline 74 & Delaware River below Perry Dam, Kans. & 24 & -- & $<10$ & $<10$ & .11 & -- \\
\hline 83 & Wakarusa River near Lawrence, Kans. & 28 & -- & $<10$ & 12 & 22 & -- \\
\hline 88 & Kansas River at DeSoto, Kans. & 38 & 4 & 6 & 10 & 16 & 29 \\
\hline
\end{tabular}


Table 15. Statistical summary of concentrations of selected dissolved metals and trace elements in water from fixed stations in lower Kansas River Basin, Kansas and Nebraska, May 1987-April 1990—Continued

\begin{tabular}{|c|c|c|c|c|c|c|c|}
\hline \multirow[b]{2}{*}{$\begin{array}{c}\text { Station } \\
\text { number } \\
\text { (flg. 9) }\end{array}$} & \multirow[b]{2}{*}{ Station name } & \multirow[b]{2}{*}{$\begin{array}{c}\text { Number } \\
\text { of } \\
\text { analyses }\end{array}$} & \multicolumn{5}{|c|}{ Concentration at indicated percentile } \\
\hline & & & 10 & 25 & $\begin{array}{c}50 \text { (me- } \\
\text { dian) }\end{array}$ & 75 & 90 \\
\hline \multicolumn{8}{|c|}{ Lithlum, dissolved } \\
\hline 1 & Kansas River at Fort Riley, Kans. & 38 & 20 & 32 & 38 & 48 & 56 \\
\hline 3 & Kings Creek near Manhattan, Kans. & 24 & -- & 8 & 11 & 16 & -- \\
\hline 23 & West Fork Big Blue river near Dorchester, Nebr. & 43 & 5 & 16 & 21 & 24 & 27 \\
\hline 35 & Big Blue River at Barneston, Nebr. & 40 & 8 & 14 & 21 & 25 & 28 \\
\hline 47 & Little Blue River at Hollenberg, Kans. & 39 & 7 & 15 & 18 & 19 & 22 \\
\hline 50 & Black Vermillion River near Frankfort, Kans. & 41 & 4 & 9 & 13 & 16 & 17 \\
\hline 52 & Big Blue River near Manhattan, Kans. & 36 & 7 & 10 & 14 & 16 & 17 \\
\hline 59 & Mill Creek near Paxico, Kans. & 38 & 7 & 10 & 15 & 18 & 20 \\
\hline 62 & Kansas River at Topeka, Kans. & 36 & 14 & 18 & 25 & 31 & 34 \\
\hline 72 & Delaware River near Muscotah, Kans. & 16 & -- & 9 & 13 & 16 & -- \\
\hline 74 & Delaware River below Perry Dam, Kans. & 15 & -- & 4 & 5 & 6 & -- \\
\hline 83 & Wakarusa River near Lawrence, Kans. & 15 & -- & 4 & 5 & 6 & -- \\
\hline 88 & Kansas River at DeSoto, Kans. & 18 & 9 & 15 & 22 & 27 & 30 \\
\hline
\end{tabular}

Manganese, dissolved

1 Kansas River at Fort Riley, Kans. $\quad 38$

3 Kings Creek near Manhattan, Kans.

23 West Fork Big Blue River near Dorchester, Nebr.

35 Big Blue River at Barneston, Nebr.

47 Little Blue River at Hollenberg, Kans.

50 Black Vermillion River near Frankfort, Kans.

52 Big Blue River near Manhattan, Kans.

59 Mill Creek near Paxico, Kans.

62 Kansas River at Topeka, Kans.

72 Delaware River near Muscotah, Kans.

74 Delaware River below Perry Dam, Kans.

83 Wakarusa River near Lawrence, Kans.

88 Kansas River at DeSoto, Kans.

$\begin{array}{rrrrrr}38 & 1 & 4 & 18 & 38 & 82 \\ 23 & -- & <1 & 2 & 3 & -- \\ 43 & 6 & 19 & 65 & 170 & 210 \\ 40 & 3 & 6 & 47 & 120 & 170 \\ 39 & 3 & 7 & 20 & 33 & 54 \\ & & & & & \\ 41 & 48 & 170 & 260 & 420 & 610 \\ 36 & 4 & 10 & 38 & 140 & 300 \\ 39 & 3 & 12 & 25 & 47 & 69 \\ 37 & <1 & 2 & 10 & 19 & 48 \\ 35 & 20 & 50 & 190 & 490 & 760 \\ & & & & & \\ 33 & 8 & 20 & 77 & 320 & 1,600 \\ 32 & 18 & 21 & 54 & 100 & 150 \\ 38 & <1 & 2 & 8 & 20 & 54\end{array}$


Table 15. Statistical summary of concentrations of selected dissolved metals and trace elements in water from fixed stations in lower Kansas River Basin, Kansas and Nebraska, May 1987-April 1990-Continued

\begin{tabular}{|c|c|c|c|c|c|c|c|}
\hline \multirow{2}{*}{$\begin{array}{c}\text { Station } \\
\text { number } \\
\text { (flg. 9) }\end{array}$} & \multirow[b]{2}{*}{ Station name } & \multirow{2}{*}{$\begin{array}{c}\text { Number } \\
\text { of } \\
\text { analyses }\end{array}$} & \multicolumn{5}{|c|}{ Concentration at indicated percentile } \\
\hline & & & 10 & 25 & $\begin{array}{l}50 \text { (me- } \\
\text { dian) }\end{array}$ & 75 & 90 \\
\hline \multicolumn{8}{|c|}{ Strontlum, dissolved } \\
\hline 1 & Kansas River at Fort Riley, Kans. & 38 & 410 & 750 & 980 & 1,200 & 1,300 \\
\hline 3 & Kings Creek near Manhattan, Kans. & 24 & -- & 560 & 960 & 1,000 & -- \\
\hline 23 & West Fork Big Blue River near Dorchester, Nebr. & 43 & 63 & 250 & 350 & 370 & 380 \\
\hline 35 & Big Blue River at Barneston, Nebr. & 40 & 130 & 260 & 360 & 410 & 440 \\
\hline 47 & Little Blue River at Hollenberg, Kans. & 39 & 110 & 270 & 310 & 340 & 360 \\
\hline 50 & Black Vermillion River near Frankfort, Kans. & 41 & 200 & 560 & 670 & 760 & 810 \\
\hline 52 & Big Blue River near Manhattan, Kans. & 36 & 260 & 350 & 470 & 510 & 540 \\
\hline 59 & Mill Creek near Paxico, Kans. & 39 & 570 & 930 & 1,200 & 1,500 & 1,800 \\
\hline 62 & Kansas River at Topeka, Kans. & 36 & 370 & 580 & 760 & 860 & 930 \\
\hline 72 & Delaware River near Muscotah, Kans. & 18 & -- & 620 & 720 & 1,000 & -- \\
\hline 74 & Delaware River below Perry Dam, Kans. & 15 & -- & 260 & 330 & 340 & -- \\
\hline 83 & Wakarusa River near Lawrence, Kans. & 15 & -- & 240 & 250 & 290 & -- \\
\hline 88 & Kansas River at DeSoto, Kans. & 38 & 330 & 500 & 660 & 750 & 880 \\
\hline
\end{tabular}



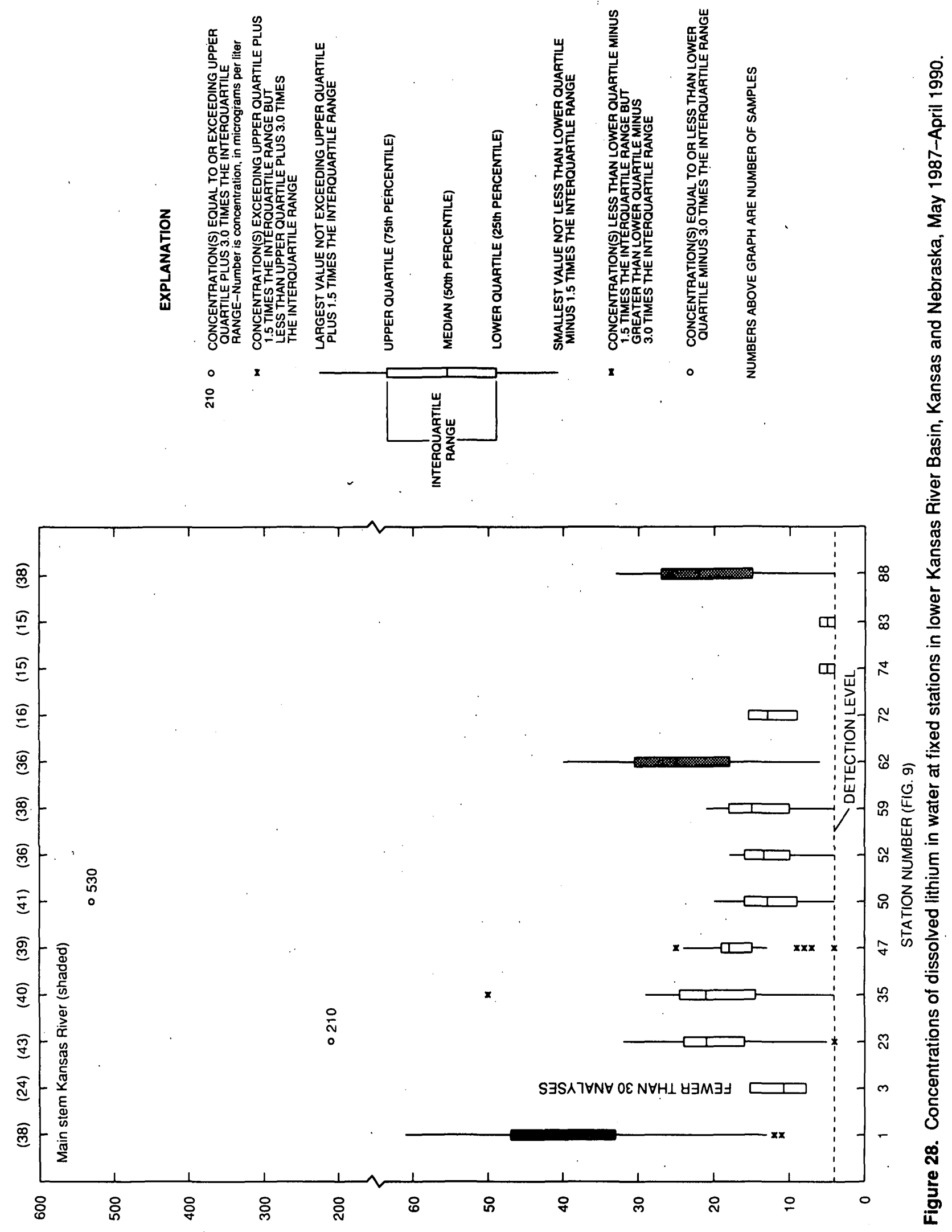

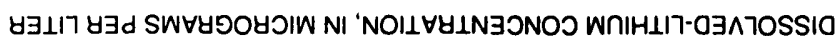




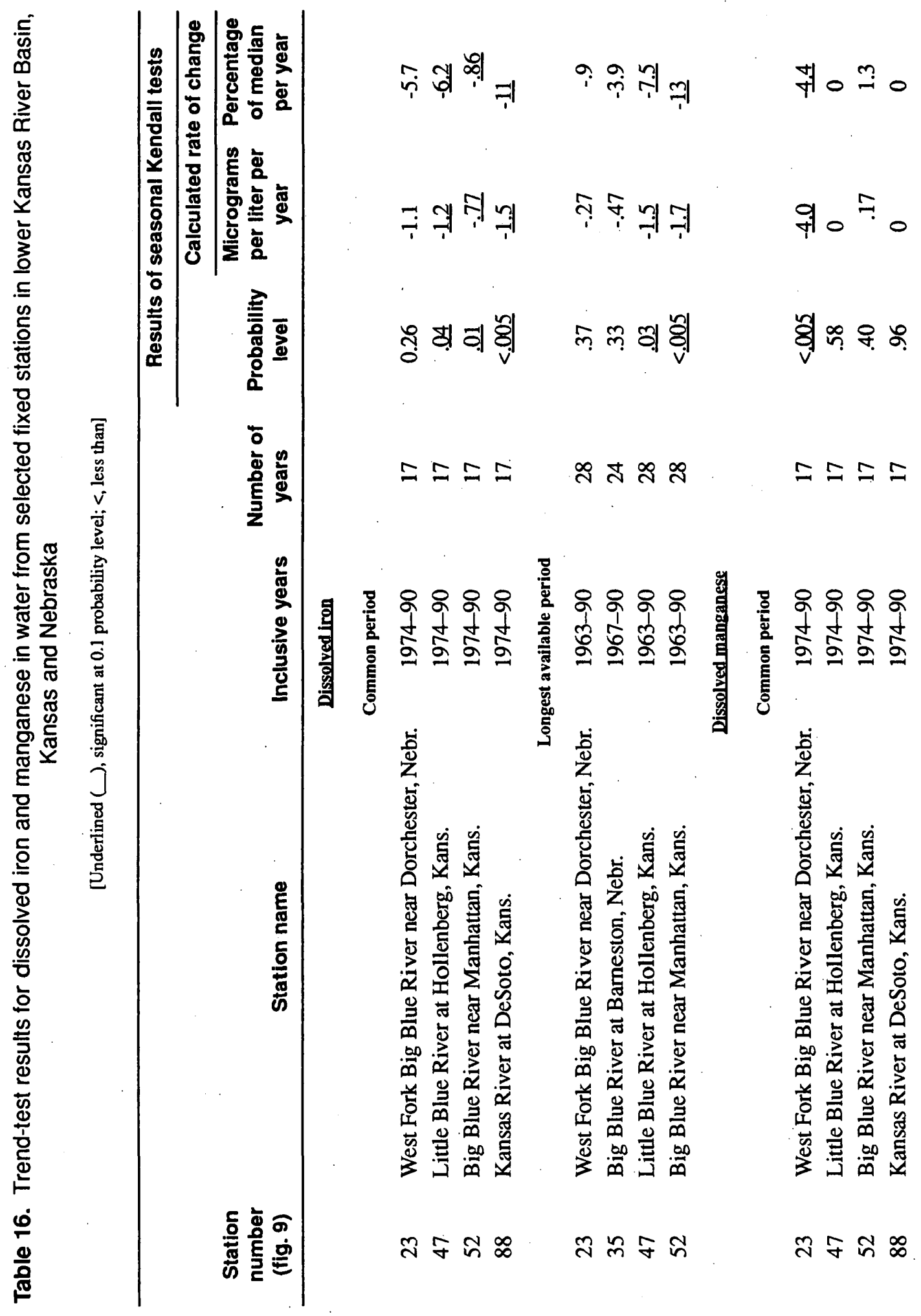




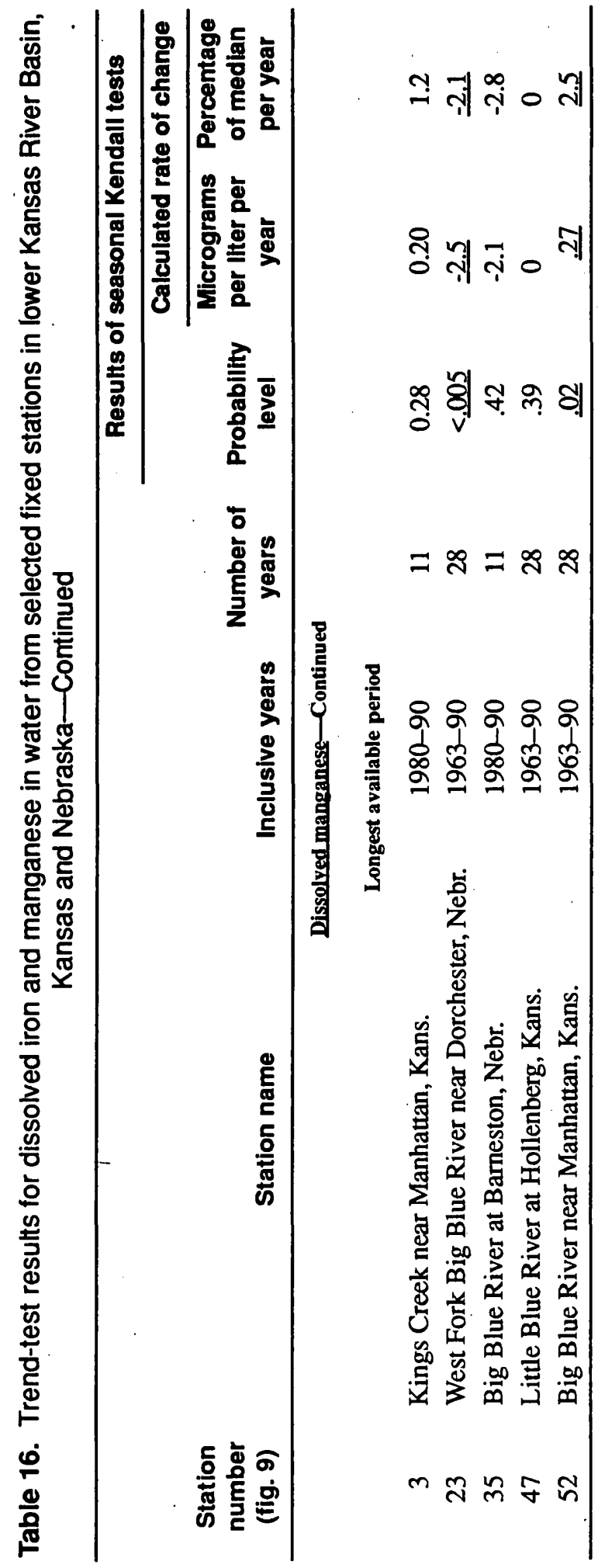


of this report; solubility of iron and manganese generally decreases as $\mathrm{pH}$ increases in natural systems (Hem, 1985).

\section{Suspended Concentrations}

A statistical summary of suspended-sediment concentrations of 13 trace elements in suspended sediment during May 1987-April 1990 is presented in table 17. Concentrations of most of those elements tended to be relatively large in suspended sediment at sampling stations directly downstream from reservoirs. For example, the median concentration of suspended chromium was largest $(100 \mu \mathrm{g} / \mathrm{g})$ in the Wakarusa River near Lawrence, Kans. (station 83), which is downstream from Clinton Lake. The median concentration of suspended lead was largest $(120 \mu \mathrm{g} / \mathrm{g})$ in the Big Blue River near Manhattan, Kans. (station 52), which is downstream from Tuttle Creek Lake. Although suspended-sediment concentrations are small downstream of dams, turbulence near the dams or the release of water from near the bottom of the reservoirs may have resulted in resuspension of sediment and the larger suspended concentrations of those trace elements that were measured.

\section{Concentrations In Streambed Sediment}

Selected results for 11 elements, based on the sampling of streambed sediment at 422 sites in first- and second-order streams during September and October 1987, are shown in table 18 along with some characteristic concentrations in soil and rock. The median and 90th-percentile concentrations generally are comparable to the characteristic concentrations for soil and rock, which would be consistent with predominantly natural sources for metals and trace elements in streambed sediment.

Data from 62 synoptic stations on major streams indicate that, in a few instances, large (exceeding the 90th percentile) concentrations of several trace metals or trace elements (most commonly, chromium, copper, lead, mercury, nickel, and zinc) were detected in the same streambedsediment sample. These conditions, at particular locations, may be associated with wastewater discharge at Aurora, Nebr., industrial waste in the
Kansas City, Kans. area, or redeposition of sediment that was suspended at the outlet of Perry Lake.

\section{Concentrations in Fish Tissue}

Fish-sample data for the lower Kansas River Basin are summarized in table 19. Median and 90th-percentile concentrations were compared for five trace elements for two time periods, 1979-86 and 1987-90. For mercury, the median and the 90th-percentile concentrations have approximately doubled from the first time period to the second; these results may be questionable because the other elements did not show such a change. The maximum mercury concentration in any sample from 1987-90 was $275 \mu \mathrm{g} / \mathrm{kg}$ from Kill Creek near DeSoto, Kans. (station 100, fig. 9). This concentration is less than the guideline for mercury in fish tissue of $0.5 \mu \mathrm{g} / \mathrm{g}(500 \mu \mathrm{g} / \mathrm{kg}$ ) (National Academy of Sciences and National Academy of Engineering, 1973).

\section{Herbicides and Insecticides by J.K. Stamer and R.B. Zelt}

Agriculture depends on the use of herbicides and insecticides to increase crop yields. Herbicides prevent or inhibit the growth of weeds that can remove nutrients and moisture needed by crops. If weeds are harvested with a crop, the value of the harvested crop is reduced. Herbicides are applied prior to planting or as pre- and postemergent compounds. Herbicides often are used in urban areas and in large quantities for nonselective weed control in industrial applications, such as use along railroad right-of-ways. Insecticides are applied to row crops at the time of planting or in a post-emergent manner; they are used to control insects that can destroy the crops by using them as a source of food. In 1990, 394 million lb of herbicides and 64 million $\mathrm{lb}$ of insecticides were used on major field crops in the United States (U.S. Department of Agriculture, 1991a).

Pesticides pose a potential threat to water quality (Smith and others, 1988; Juracek and others, 1992), and many of these compounds have been detected in surface and ground water during the last several decades. Gilliom and others (1985) concluded that patterns of pesticide detection in 
Table 17. Statistical summary of concentrations of trace elements in suspended sediment from selected fixed stations in lower Kansas River Basin, Kansas and Nebraska, May 1987-April 1990

[Concentrations in micrograms per gram; this table includes only those stations having 10 or more analyses; --, the 10- and 90-percentile values are not shown for stations having fewer than 30 analyses; <, less than]

\begin{tabular}{|c|c|c|c|c|c|c|c|}
\hline \multirow{2}{*}{$\begin{array}{c}\text { Station } \\
\text { number } \\
\text { (flg. 9) }\end{array}$} & \multirow[b]{2}{*}{ Station name } & \multirow{2}{*}{$\begin{array}{c}\text { Num- } \\
\text { ber of } \\
\text { analy- } \\
808\end{array}$} & \multicolumn{5}{|c|}{ Concentration at Indlcated percentile } \\
\hline & & & 10 & 25 & $\begin{array}{c}50 \text { (me- } \\
\text { dian) }\end{array}$ & 75 & 90 \\
\hline \multicolumn{8}{|c|}{ Antimony, sediment, suspended } \\
\hline 1 & Kansas River at Fort Riley, Kans. & 30 & 0.4 & 0.9 & 1.1 & 1.4 & 4.2 \\
\hline 23 & West Fork Big Blue River near Dorchester, Nebr. & 19 & -- & .8 & 1.0 & 1.1 & -- \\
\hline 35 & Big Blue River at Barneston, Nebr. & 13 & -- & 1.0 & $1: 1$ & 1.2 & -- \\
\hline 47 & Little Blue River at Hollenberg, Kans. & 19 & -- & .6 & .9 & 1.0 & -- \\
\hline 50 & Black Vermillion River near Frankfort, Kans. & 27 & -- & .9 & 1.1 & 1.3 & -- \\
\hline 52 & Big Blue River near Manhattan, Kans. & 11 & -- & 1.2 & 1.7 & 5.2 & -- \\
\hline 59 & Mill Creek near Paxico, Kans. & 15 & -- & .7 & .8 & .9 & -- \\
\hline 62 & Kansas River at Topeka, Kans. & 27 & -- & .7 & .9 & 1.2 & -- \\
\hline 72 & Delaware River near Muscotah, Kans. & 25 & -- & 1.0 & 1.2 & 1.4 & -- \\
\hline 83 & Wakarusa River near Lawrence, Kans. & 24 & -- & .9 & 1.0 & 1.2 & -- \\
\hline 88 & Kansas River at DeSoto, Kans. & 31 & .4 & .7 & .9 & 1.1 & 2.8 \\
\hline \multicolumn{8}{|c|}{ Arsenic, sediment, suspended } \\
\hline 1 & Kansas River at Fort Riley, Kans. & 30 & 5.7 & 7.2 & 9.8 & 12 & 15 \\
\hline 23 & West Fork Big Blue River near Dorchester, Nebr. & 19 & -- & 7.6 & 12 & 14 & -- \\
\hline 35 & Big Blue River at Barneston; Nebr. & 13 & $\cdots$ & 11 & 13 & 15 & -- \\
\hline 47 & Little Blue River at Hollenberg, Kans. & 19. & -- & 5.4 & 7.7 & 13 & -- \\
\hline 50 & Black Vermillion River near Frankfort, Kans. & 27 & -- & 13 & 15 & 18 & -- \\
\hline 52 & Big Blue River near Manhattan, Kans. & 11 & -- & 11 & 13 & 14 & -- \\
\hline 59 & Mill Creek near Paxico, Kans. & 15 & -- & 7.0 & 8.8 & 15 & -- \\
\hline 62 & Kansas River at Topeka, Kans. & 27 & -- & 7.2 & 10 & 12 & -- \\
\hline 72 & Delaware River near Muscotah, Kans. & 25 & -- & 11 & 13 & 15 & -- \\
\hline 83 & Wakarusa River near Lawrence, Kans. & 25 & -- & 10 & 12 & 15 & -- \\
\hline 88 & Kansas River at DeSoto, Kans. & 31 & 4.9 & 8.0 & 9.6 & 12 & 15 \\
\hline \multicolumn{8}{|c|}{ Beryllium, sediment, suspended } \\
\hline 1 & Kansas River at Fort Riley, Kans. & 29 & -- & $<2$ & $<2$ & 2 & -- \\
\hline 23 & West Fork Big Blue River near Dorchester, Nebr. & 19 & $\therefore$ & 2 & 3 & 3 & -. \\
\hline 35 & Big Blue River at Barneston, Nebr. & 13 & -- & 2 & 3 & 3 & -- \\
\hline 47 & Little Blue River at Hollenberg, Kans. & 19 & -- & $<2$ & 2 & 3 & -- \\
\hline 50 & Black Vermillion River near Frankfort, Kans. & 26 & -- & 2 & 2 & 2 & -- \\
\hline
\end{tabular}


Table 17. Statistical summary of concentrations of trace elements in suspended sediment from selected fixed stations in lower Kansas River Basin, Kansas and Nebraska, May 1987-April 1990_Continued

\begin{tabular}{|c|c|c|c|c|c|c|c|}
\hline \multirow{2}{*}{$\begin{array}{c}\text { Station } \\
\text { number } \\
\text { (fig. 9) }\end{array}$} & \multirow[b]{2}{*}{ Station name } & \multirow{2}{*}{$\begin{array}{c}\text { Num- } \\
\text { ber of } \\
\text { analy- } \\
\text { ses }\end{array}$} & \multicolumn{5}{|c|}{ Concentration at indicated percentile } \\
\hline & & & 10 & 25 & $\begin{array}{l}50 \text { (me- } \\
\text { dlan) }\end{array}$ & 75 & 90 \\
\hline \multicolumn{8}{|c|}{ Beryllium, sediment, suspended-Continued } \\
\hline 52 & Big Blue River near Manhattan, Kans. & 10 & -- & $<2$ & 2 & 3 & -- \\
\hline 59 & Mill Creek near Paxico, Kans. & 14 & -- & $<2$ & 2 & 3 & -- \\
\hline 62 & Kansas River at Topeka, Kans. & 27 & -- & $<2$ & $<2$ & 2 & $-\therefore$ \\
\hline 72 & Delaware River near Muscotah, Kans. & 23 & -- & $<2$ & 2 & 2 & -- \\
\hline 83 & Wakarusa River near Lawrence, Kans. & 23 & -- & 2 & 3 & 3 & -- \\
\hline 88 & Kansas River at DeSoto, Kans. & 28 & -- & $<2$ & 2 & 2 & -- \\
\hline \multicolumn{8}{|c|}{ Cadmium, sediment, suspended } \\
\hline 1 & Kansas River at Fort Riley, Kans. & 30 & 0.8 & 1.4 & 2.5 & 4.5 & 11. \\
\hline 23 & West Fork Big Blue River near Dorchester, Nebr. & 19 & -- & .7 & 1.1 & 1.4 & -- \\
\hline 35 & Big Blue River at Barneston, Nebr. & 13 & -- & .7 & 1.5 & 2.7 & -- \\
\hline 47 & Little Blue River at Hollenberg, Kans. & 19 & -- & .7 & 1.0 & 2.4 & -- \\
\hline 50 & Black Vermillion River near Frankfort, Kans. & 27 & -- & 1.2 & 1.8 & 5.4 & -- \\
\hline 52 & Big Blue River near Manhattan, Kans. & 11 & -- & 2.5 & 4.0 & 7.6 & -- \\
\hline 59 & Mill Creek near Paxico, Kans. & 15 & -- & 1.5 & 3.2 & 16 & -- \\
\hline 62 & Kansas River at Topeka, Kans. & 27 & -- & 1.4 & 2.5 & 5.0 & -- \\
\hline 72 & Delaware River near Muscotah, Kans. & 25 & -- & 1.1 & 2.0 & 8.9 & -- \\
\hline 83 & Wakarusa River near Lawrence, Kans. & 24 & -- & 2.1 & 2.8 & 6.7 & -- \\
\hline 88 & Kansas River at DeSoto, Kans. & 31 & .7 & 1.1 & 1.7 & 4.1 & 10 \\
\hline \multicolumn{8}{|c|}{ Chromium, sediment, suspended } \\
\hline 1 & Kansas River at Fort Riley, Kans. & 23 & -- & 45 & 61 & 75 & -- \\
\hline 23 & West Fork Big Blue River near Dorchester, Nebr. & 14 & -- & 64 & 74 & 76 & -- \\
\hline 47 & Little Blue River at Hollenberg, Kans. & 13 & -- & 47 & 66 & 73 & -- \\
\hline 50 & Black Vermillion River near Frankfort, Kans. & 19 & -- & 70 & 79 & 81 & -- \\
\hline 52 & Big Blue River near Manhattan, Kans. & 11 & -- & 68 & 81 & 90 & -- \\
\hline 59 & Mill Creek near Paxico, Kans. & 15 & -- & 65 & 74 & 84 & -. \\
\hline 62 & Kansas River at Topeka, Kans. & 27 & -- & 36 & 51 & 63 & -- \\
\hline 72 & Delaware River near Muscotah, Kans. & 25 & -- & 62 & 80 & 90 & -- \\
\hline 83 & Wakarusa River near Lawrence, Kans. & 25 & -- & 94 & 100 & 110 & -- \\
\hline 88 & Kansas River at DeSoto, Kans. & 31 & 25 & 45 & 54 & 76 & 87 \\
\hline
\end{tabular}


Table 17. Statistical summary of concentrations of trace elements in suspended sediment from selected fixed stations in lower Kansas River Basin, Kansas and Nebraska, May 1987-April 1990-Continued

\begin{tabular}{|c|c|c|c|c|c|c|c|}
\hline \multirow{2}{*}{$\begin{array}{c}\text { Station } \\
\text { number } \\
\text { (flg. 9) }\end{array}$} & \multirow[b]{2}{*}{ Station name } & \multirow{2}{*}{$\begin{array}{c}\text { Num- } \\
\text { ber of } \\
\text { analy- } \\
\text { ses }\end{array}$} & \multicolumn{5}{|c|}{ Concentratlon at Indlcated percentlle } \\
\hline & & & 10 & 25 & $\begin{array}{c}50 \text { (me- } \\
\text { dian) }\end{array}$ & 75 & 90 \\
\hline \multicolumn{8}{|c|}{ Cobalt, sediment, suspended } \\
\hline 1 & Kansas River at Fort Riley, Kans. & 30 & 6 & 8 & 11 & 12 & 13 \\
\hline 23 & West Fork Big Blue River near Dorchester, Nebr. & 19 & -- & 13 & 14 & 15 & -- \\
\hline 35 & Big Blue River at Barneston, Nebr. & 13 & -. & 11 & 14 & 15 & -- \\
\hline 47 & Little Blue River at Hollenberg, Kans. & 19 & -- & 10 & 12 & 14 & -- \\
\hline 50 & Black Vermillion River near Frankfort, Kans. & 26 & -- & 15 & 16 & 19 & -- \\
\hline 52 & Big Blue River near Manhattan, Kans. & 11 & -- & 11 & 13 & 15 & $-\cdot$ \\
\hline 59 & Mill Creek near Paxico, Kans. & 15 & -- & 13 & 15 & 16 & -- \\
\hline 62 & Kansas River at Topeka, Kans. & 27 & -- & 9 & 11 & 12 & -- \\
\hline 72 & Delaware River near Muscotah, Kans. & 25 & -- & 13 & 19 & 25 & -- \\
\hline 83 & Wakarusa River near Lawrence, Kans. & 25 & -- & 14 & 17 & 18 & -- \\
\hline 88 & Kansas River at DeSoto, Kans. & 31 & 6 & 9 & 12 & 13 & 14 \\
\hline \multicolumn{8}{|c|}{ Copper, sediment, suspended } \\
\hline 1 & Kansas River at Fort Riley, Kans. & 30 & 17 & 30 & 34 & 52 & 62 \\
\hline 23 & West Fork Big Blue River near Dorchester, Nebr. & 19 & -- & 31 & 35 & 50 & -- \\
\hline 35 & Big Blue River at Barneston; Nebr. & 13 & -- & 38 & 47 & 76 & -- \\
\hline 47 & Little Blue River at Hollenberg, Kans. & 19 & -- & 20 & 32 & 51 & -- \\
\hline 50 & Black Vermillion River near Frankfort, Kans. & 26 & -- & 29 & 36 & 54 & -- \\
\hline 52 & Big Blue River near Manhattan, Kans. & 11 & -- & 32 & 60 & 84 & -- \\
\hline 59 & Mill Creek near Paxico, Kans. & 15 & -- & 34 & 36 & 48 & -- \\
\hline 62 & Kansas River at Topeka, Kans. & 27 & -- & 25 & 33 & 47 & -- \\
\hline 72 & Delaware River near Muscotah, Kans. & 25 & -- & 30 & 48 & 70 & -- \\
\hline 83 & Wakarusa River near Lawrence, Kans. & 25 & - & 34 & 45 & 66 & -- \\
\hline 88 & Kansas River at DeSoto, Kans. & 31 & 23 & 29 & 39 & 48 & 74 \\
\hline \multicolumn{8}{|c|}{ Lead, sediment, suspended } \\
\hline 1 & Kansas River at Fort Riley, Kans. & 30 & 22 & 26 & 38 & 57 & 170 \\
\hline 23 & West Fork Big Blue River near Dorchester, Nebr. & 19 & -- & 28 & 31 & 49 & -- \\
\hline 35 & Big Blue River at Barneston, Nebr. & 13 & -- & 28 & 37 & 43 & -- \\
\hline 47 & Little Blue River at Hollenberg, Kans. & 19 & $\div-$ & 20 & 27 & 35 & -- \\
\hline 50 & Black Vermillion River near Frankfort, Kans. & 27 & -- & 30 & 43 & 62 & -- \\
\hline
\end{tabular}


Table 17. Statistical summary of concentrations of trace elements in suspended sediment from selected fixed stations in lower Kansas River Basin, Kansas and Nebraska, May 1987-April 1990-Continued

\begin{tabular}{|c|c|c|c|c|c|c|c|}
\hline \multirow{2}{*}{$\begin{array}{c}\text { Station } \\
\text { number } \\
\text { (fig. 9) }\end{array}$} & \multirow[b]{2}{*}{ Station name } & \multirow{2}{*}{$\begin{array}{c}\text { Num- } \\
\text { ber of } \\
\text { analy- } \\
\text { ses }\end{array}$} & \multicolumn{5}{|c|}{ Concentration at indlcated percentlle } \\
\hline & & & 10 & 25 & $\begin{array}{c}50 \text { (me- } \\
\text { dlan) }\end{array}$ & 75 & 90 \\
\hline \multicolumn{8}{|c|}{ Lead, sediment, suspended—Continued } \\
\hline 52 & Big Blue River near Manhattan, Kans. & 11 & -- & 38 & 120 & 190 & -- \\
\hline 59 & Mill Creek near Paxico, Kans. & 15 & -- & 31 & 40 & 87 & -- \\
\hline 62 & Kansas River at Topeka, Kans. & 27 & -- & 23 & 28 & 36 & -- \\
\hline 72 & Delaware River near Muscotah, Kans. & 25 & -- & 30 & 40 & 66 & -- \\
\hline 83 & Wakarusa River near Lawrence, Kans. & 24 & -- & 31 & 38 & 48 & -- \\
\hline 88 & Kansas River at DeSoto, Kans. & 31 & 20 & 25 & 32 & 43 & 110 \\
\hline \multicolumn{8}{|c|}{ Molybdenum, sediment, suspended } \\
\hline 1 & Kansas River at Fort Riley, Kans. & 24 & -- & 1.5 & 2.8 & 3.9 . & -- \\
\hline 23 & West Fork Big Blue River near Dorchester, Nebr. & . 14 & -- & .8 & .9 & 1.1 & -- \\
\hline 47 & Little Blue River at Hollenberg, Kans. & 13 & -- & 6 & .9 & 1.0 & -- \\
\hline 50 & Black Vermillion River near Frankfort, Kans. & 20 & -- & .9 & 1.4 & 2.2 & -- \\
\hline 52 & Big Blue River near Manhattan, Kans. & 11 & -- & .9 & 2.9 & 5.1 & -- \\
\hline 59 & Mill Creek near Paxico, Kans. & 15 & -- & .7 & 1.1 & 2.0 & -- \\
\hline 62 & Kansas River at Topeka, Kans. & 27 & -- & 1.4 & 2.0 & 3.6 & -- \\
\hline 72 & Delaware River near Muscotah, Kans. & 25 & -- & 1.1 & 3.2 & 5.3 & -- \\
\hline 83 & Wakarusa River near Lawrence, Kans. & 24 & -- & 1.1 & 1.3 & 1.7 & -- \\
\hline 88 & Kansas River at DeSoto, Kans. & 31 & .8 & 1.2 & 1.7 & 3.0 & 5.6 \\
\hline
\end{tabular}

Nickel, sediment, suspended

$\begin{array}{rlrrrrrr}1 & \text { Kansas River at Fort Riley, Kans. } & 23 & -- & 25 & 33 & 38 & -- \\ 23 & \text { West Fork Big Blue River near Dorchester, Nebr. } & 14 & -- & 33 & 38 & 48 & -- \\ 47 & \text { Little Blue River at Hollenberg, Kans. } & 13 & -- & 28 & 34 & 52 & -- \\ 50 & \text { Black Vermillion River near Frankfort, Kans. } & 19 & -- & 35 & 43 & 48 & -- \\ 52 & \text { Big Blue River near Manhattan, Kans. } & 11 & -- & 34 & 37 & 52 & -- \\ & & & & & & & \\ 59 & \text { Mill Creek near Paxico, Kans. } & 15 & -- & 32 & 41 & 44 & -- \\ 62 & \text { Kansas River at Topeka, Kans. } & 27 & -- & 22 & 29 & 34 & -- \\ 72 & \text { Delaware River near Muscotah, Kans. } & 25 & -- & 34 & 51 & 62 & - \\ 83 & \text { Wakarusa River near Lawrence, Kans. } & 25 & -- & 42 & 48 & 57 & -- \\ 88 & \text { Kansas River at DeSoto, Kans. } & 31 & 20 & 25 & 35 & 40 & 45\end{array}$


Table 17. Statistical summary of concentrations of trace elements in suspended sediment from selected fixed stations in lower Kansas River Basin, Kansas and Nebraska, May 1987-April 1990-Continued

\begin{tabular}{|c|c|c|c|c|c|c|c|}
\hline \multirow{2}{*}{$\begin{array}{l}\text { Station } \\
\text { number } \\
\text { (flg. 9) }\end{array}$} & \multirow[b]{2}{*}{ Station name } & \multirow{2}{*}{$\begin{array}{l}\text { Num- } \\
\text { ber of } \\
\text { analy- } \\
\text { ses }\end{array}$} & \multicolumn{5}{|c|}{ Concentration at Indicated percentlle } \\
\hline & & & 10 & 25 & $\begin{array}{l}50 \text { (me- } \\
\text { dian) }\end{array}$ & 75 & 90 \\
\hline \multicolumn{8}{|c|}{ Silver, sediment, suspended } \\
\hline 1 & Kansas. River at Fort Riley, Kans. & 30 & $<0.1$ & $<0.1$ & 0.2 & 0.5 & 0.7 \\
\hline 23 & West Fork Big Blue River near Dorchester, Nebr. & 19 & -- & .1 & .2 & .5 & -- \\
\hline 35 & Big Blue River at Barneston, Nebr. & 13 & -- & .1 & .2 & .5 & -- \\
\hline 47 & Little Blue River at Hollenberg, Kans. & 19 & -- & .1 & .2 & .4 & -- \\
\hline 50 & Black Vermillion River near Frankfort, Kans. & 27 & -- & .1 & .2 & .3 & -- \\
\hline 52 & Big Blue River near Manhattan, Kans. & 11 & -- & .2 & .2 & .7 & -- \\
\hline 59 & Mill Creek near Paxico, Kans. & 15 & -- & .1 & .2 & .3 & -- \\
\hline 62 & Kansas River at Topeka, Kans. & 27 & -- & .2 & .2 & .4 & -. \\
\hline 72 & Delaware River near Muscotah, Kans. & 25 & -- & .1 & .2 & .4 & -- \\
\hline 83 & Wakarusa River near Lawrence, Kans. & 24 & -- & .2 & .3 & .4 & -- \\
\hline 88 & Kansas River at DeSoto, Kans. & 31 & .2 & .2 & .3 & .5 & .8 \\
\hline \multicolumn{8}{|c|}{ Vanadium, sediment, suspended } \\
\hline 1 & Kansas River at Fort Riley, Kans. & 30 & 29 & 60 & 92 & 130 & 150 \\
\hline 23 & West Fork Big Blue River near Dorchester, Nebr. & 19 & -- & 100 & 110 & 140 & -- \\
\hline 35 & Big Blue River at Barneston, Nebr. & 13 & -- & 110 & 130 & 140 & -- \\
\hline 47 & Little Blue River at Hollenberg, Kans. & 19 & -- & 72 & 92 & 130 & -- \\
\hline 50 & Black Vermillion River near Frankfort, Kans. & 26 & -- & 110 & 130 & 130 & -- \\
\hline 52 . & Big Blue River near Manhattan, Kans. & 11 & -- & 83 & 110 & 130 & -- \\
\hline 59 & Mill Creek near Paxico, Kans. & 15 & -- & 72 & 86 & 110 & -- \\
\hline 62 & Kansas River at Topeka, Kans. & 27 & -- & 59 & 76 & 110 & -- \\
\hline 72 & Delaware River near Muscotah, Kans. & 25 & -- & 82 & 110 & 120 & -- \\
\hline 83 & Wakarusa River near Lawrence, Kans. & 25 & -- & 120 & 120 & 130 & -- \\
\hline 88 & Kansas River at DeSoto, Kans. & 31 & 36 & 62 & 90 & 120 & 130 \\
\hline \multicolumn{8}{|c|}{ Zinc, sediment, suspended } \\
\hline 1 & Kansas River at Fort Riley, Kans. & 23 & -. & 120 & 160 & 190 & -- \\
\hline 23 & West Fork Big Blue River near Dorchester, Nebr. & 14 & -- & 120 & 160 & 200 & -- \\
\hline 47 & Little Blue River at Hollenberg, Kans. & 13 & -- & 130 . & 160 & 190 & -- \\
\hline 50 & Black Vermillion River near Frankfort, Kans. & 19 & -- & 130 & 150 & 190 & -- \\
\hline 52 & Big Blue River near Manhattan, Kans. & 11 & -- & 170 & 180 & 220 & -- \\
\hline
\end{tabular}


Table 17. Statistical summary of concentrations of trace elements in suspended sediment from selected fixed stations in lower Kansas River Basin, Kansas and Nebraska, May 1987-April 1990-Continued

\begin{tabular}{|c|c|c|c|c|c|c|c|}
\hline \multirow{2}{*}{$\begin{array}{c}\text { Station } \\
\text { number } \\
\text { (fig. 9) }\end{array}$} & \multirow[b]{2}{*}{ Station name } & \multirow{2}{*}{$\begin{array}{c}\text { Num- } \\
\text { ber of } \\
\text { analy- } \\
\text { ses }\end{array}$} & \multicolumn{5}{|c|}{ Concentration at indicated percentlle } \\
\hline & & & 10 & 25 & $\begin{array}{c}50 \text { (me- } \\
\text { dian) }\end{array}$ & 75 & 90 \\
\hline \multicolumn{8}{|c|}{ Zinc, sediment, suspended-Continued } \\
\hline 59 & Mill Creek near Paxico, Kans. & 15 & -- & 100 & 140 & 180 & -- \\
\hline 62 & Kansas River at Topeka, Kans. & 27 & -- & 110 & 120 & 170 & -- \\
\hline 72 & Delaware River near Muscotah, Kans. & 25 & -- & 140 & 160 & 210 & -- \\
\hline 83 & Wakarusa River near Lawrence, Kans. & 25 & -- & 170 & 190 & 230 & -- \\
\hline 88 & Kansas River at DeSoto, Kans. & 31 & 73 & 110 & 140 & 160 & 220 \\
\hline
\end{tabular}

Table 18. Median and 90th-percentile concentrations of selected elements in streambed sediment of first- and second-order streams in lower Kansas River Basin, Kansas and Nebraska, September-October 1987, geometric mean concentrations in soils of the western United States, and abundance in selected rock types

[All values are expressed as total recoverable concentrations, in micrograms per gram]

\begin{tabular}{|c|c|c|c|c|c|c|}
\hline \multirow[b]{2}{*}{ Element } & $\begin{array}{c}\text { Concentra } \\
\text { Kansas }\end{array}$ & $\begin{array}{l}\text { ns in lower } \\
\text { ver Basin }\end{array}$ & \multirow{2}{*}{$\begin{array}{l}\text { Geometric } \\
\text { mean } \\
\text { concen- } \\
\text { tration in } \\
\text { soils of the } \\
\text { western } \\
\text { United } \\
\text { States }^{1}\end{array}$} & \multicolumn{3}{|c|}{ Abundance in rock types ${ }^{2}$} \\
\hline & Median & $\begin{array}{c}\text { 90th- } \\
\text { percentile }\end{array}$ & & Shale & Sandstone & $\begin{array}{c}\text { Carbonate } \\
\text { rocks }\end{array}$ \\
\hline Arsenic & 6.4 & 11 & 5.5 & 95 & 16 & 20 \\
\hline Barium & 690 & 780 & 580 & 580 & $10-90$ & 10 \\
\hline Chromium & 45 & 57 & 41 & 90 & 35 & 11 \\
\hline Cobalt & 11 & 21 & 7.1 & 19 & .3 & .1 \\
\hline Copper & 15 & 19 & 21 & 45 & $1-9$ & 4 \\
\hline Lead & 20 & 29 & 17 & 20 & 7 & 9 \\
\hline Manganese & 550 & 1,400 & 380 & 850 & $10-90$ & 1,100 \\
\hline Nickel & 18 & 29 & 15 & 68 & 2 & 20 \\
\hline Strontium & 160 & 200 & 200 & 300 & 20 & 610 \\
\hline Vanadium & 71 & 87 & 70 & 130 & 20 & 20 \\
\hline Zinc & 56 & 79 & 55 & 95 & 16 & 20 \\
\hline
\end{tabular}

${ }^{1}$ Based on data in Shacklette and Boerngen (1984).

${ }^{2}$ Parker (1967). 
Table 19. Summary of data for selected trace elements in composite samples of whole fish from 14 . sampling stations, 1979-86, and from 12 sampling stations, 1987-90, in the lower Kansas River Basin, Kansas and Nebraska

[Concentrations are in micrograms per kilogram; --, 90th-percentile concentrations are not shown for constituents having fewer than 30 analyses; $<$, less than. Sources of data are the U.S. Environmental Protection Agency STORET system and Lowe and others $(1985$, p. 385)]

\begin{tabular}{|c|c|c|c|c|c|c|}
\hline \multirow[b]{2}{*}{ Element } & \multicolumn{2}{|c|}{ Number of samples } & \multicolumn{2}{|c|}{ Median concentration } & \multicolumn{2}{|c|}{$\begin{array}{l}\text { 90th-percentlle } \\
\text { concentration }\end{array}$} \\
\hline & $1979-86$ & $1987-90$ & $1979-86$ & $1987-90$ & $1976-86$ & $1987-90$ \\
\hline$\overline{\text { Cadmium }}$ & 45 & 33 & 70 & 90 & 290 & 250 \\
\hline Copper & 41 & 11 & 980 & 1,000 & 1,600 & -- \\
\hline Lead & ${ }^{1} 12$ & 33 & 150 & $<500$ & -- & 500 \\
\hline Mercury & 44 & 32 & 50 & 100 & 95 & 220 \\
\hline Zinc & 41 & 10 & 52,000 & 51,000 & 78,000 & - \\
\hline
\end{tabular}

${ }^{1}$ Excludes samples for which analyses had a detection level of 500 micrograms per kilogram.

surface water depend on several factors, which include usage, persistence, solubility, and detection levels. Atrazine was the most frequently detected pesticide in surface water at a detection level of $0.5 \mu \mathrm{g} / \mathrm{L}$. The rate of detection was 4.8 percent, based on 1,363 samples from across the United States. However, the rate of detection of atrazine in samples of water was 30 percent in the principal corn- and sorghum-producing states, a region that accounted for 63 percent of the 1976 atrazine use in the Nation. Characteristics of the major herbicide and insecticide classes that have been used extensively in the study unit were described by Gilliom and others (1985) and Bevans (1991). The pesticides most extensively applied in the study unit during 1989 are listed in table 20.

It has become important to understand when and where surface water is most likely to contain large concentrations of one or more pesticides. These pesticides are addressed in existing or newly proposed U.S. Environmental Protection Agency's (1990) National Primary Drinking-Water Regulations, the National Academy of Sciences and National Academy of Engineering (1973) guidelines for the protection of fish-eating birds and predators, and the U.S. Food and Drug Administration's (1989) action levels for pesticide residues in fish for human consumption. In the Kansas part of the study unit, surface water is a major source of public supply. Surface water is a vulnerable resource because it receives considerable runoff from agricultural land. Mean monthly runoff is larger in the spring and summer, which corresponds to the growing season, and is smaller in the late fall and early winter. Knowledge of the relation of the distribution of pesticides in surface water to usage or other factors will be valuable to water-resource managers and planners.

This section of the report describes the spatial and temporal distribution of herbicides and insecticides in the lower Kansas River Basin, May 1987 through February 1990. The study approach included runoff-oriented sampling and analysis of nitrogen-containing herbicides in the spring of 1987; collection and analysis of samples for nitrogen-containing and thiocarbamate herbicides in surface water from 56-61 of the 77 synoptic stations in the study unit during low flow of each season from the summer of 1988 to the spring of 1989; collection and analysis of samples for other herbicides and insecticides in surface water from 14 of the synoptic stations during low flow in three of the seasons; monthly or more frequent sampling of 12 of the 13 fixed stations (Kings Creek near Manhattan, Kans., was excluded because of periodic no flow) from March 1989 through February 1990 to provide samples that covered the range of expected streamflows; collection of streambed sediment at 60 of the synoptic stations for analysis of organochlorine insecticides; and the use of fish-tissue data from the Kansas Department of Health and Environment and the Nebraska Department of Environmental Quality. A statistical summary of results for herbicides and insecticides 
Table 20. Estimated quantities of pesticides used in the lower Kansas River Basin, Kansas and Nebraska, 1989

[Estimated from Kansas State Board of Agriculture, 1989; Baker and others, 1990; Gianessi and Puffer, 1991; Kansas State University, 1991; and based on digital land-use data for Kansas (1973-74) from the U.S. Geological Survey and for Nebraska (1983-89) from the Nebraska Natural Resources Commission]

\begin{tabular}{clc}
\hline Rank & Compound & $\begin{array}{c}\text { Quantity } \\
\text { applled } \\
\text { (millions of } \\
\text { pounds of } \\
\text { active } \\
\text { Ingredlent) }\end{array}$ \\
\hline 1 & Atrazine & 3.89 \\
2 & Alachlor & 1.04 \\
3 & Metolachlor & .97 \\
4 & Propachlor & .54 \\
5 & Cyanazine & .54 \\
& & \\
6 & Butylate & .49 \\
7 & Terbufos & .37 \\
8 & Trifluralin & .33 \\
9 & EPTC & .27 \\
10 & $2,4-D$ & .23 \\
11 & Chlorpyrifos & .20 \\
12 & Propazine & .14 \\
13 & Carbofuran & .11 \\
14 & Pendimethalin & .09 \\
\hline
\end{tabular}

in all water samples collected from May 1987 through February 1990 is presented in table 21.

\section{Organonitrogen Herblcides}

As a group, the organonitrogen herbicides, such as alachlor, atrazine, and metolachlor, are used extensively throughout the study unit. Atrazine was by far the most extensively used pesticide in the study unit (table 20).

During low flow, shallow ground water contributes most of the water in unregulated streams. Residues of organonitrogen herbicides in surface water during base flow indicate that these compounds are soluble, able to leach through the soil and enter shallow aquifers that recharge the streams, and are relatively persistent. Atrazine was the most frequently detected herbicide and had the largest concentrations of any pesticide measured in surface water during low flow (Stamer and Zelt, 1992). In general, the largest concentrations of atrazine were measured in the Big Blue River subbasin upstream of Tuttle Creek Lake where the largest quantities of atrazine were applied to the land (fig. 29) (atrazine use in 1988 is assumed to be similar to use in 1989, which is shown in the figure). During low flow of July 1988, the median concentration of atrazine in samples from 61 synoptic stations was $2.6 \mu \mathrm{g} / \mathrm{L}$ (fig. 30); atrazine was detected in all 61 samples, and 38 percent of the samples had concentrations of atrazine larger than the established MCL of $3.0 \mu \mathrm{g} / \mathrm{L}$ (U.S. Environmental Protection Agency, 1992). Following atrazine, in order of decreasing frequency of detection, were metolachlor (77 percent of 61 samples), cyanazine ( 75 percent of 61 samples), and simazine ( 72 percent of 61 samples). Following atrazine, the median low-flow concentrations of these compounds followed the same decreasing order, and these median concentrations ranged from 0.1 to $0.3 \mu \mathrm{g} / \mathrm{L}$ (fig. 30).

Concentrations of atrazine in surface water during low-flow synoptic sampling also varied seasonally (fig. 31); the largest median concentrations occurred in spring (May-June) and summer (July) and the smaller in fall and winter (November and March). The median concentration of atrazine in the fall and winter low-flow samples was $0.3 \mu \mathrm{g} / \mathrm{L}$. Metolachlor, the second most frequently detected organonitrogen herbicide, showed a seasonal pattern similar to atrazine, but concentrations were smaller, as shown in figure 31. Atrazine concentrations in the Kansas River at eight stations downstream from the confluence with the Big Blue River during low flow in July and November 1988 ranged from 1.9 to $2.8 \mu \mathrm{g} / \mathrm{L}$ as a result of low-flow augmentation from upstream reservoirs on the Big Blue and Delaware Rivers. Even in March 1989, three of eight concentrations of atrazine in water from stations on the Kansas River downstream from the Big Blue River ranged from 1.1 to $1.4 \mu \mathrm{g} / \mathrm{L}$.

Atrazine concentrations varied seasonally from March 1989 through February 1990, based on sampling at 12 fixed stations that covered the range of expected streamflows. The largest concen- 
Table 21. Statistical summary of concentrations of herbicides and insecticides in water from streams in lower Kansas River Basin, Kansas and Nebraska, May 1987-February 1990

[Concentrations in micrograms per liter; $<$, less than]

\begin{tabular}{|c|c|c|c|c|c|c|c|c|}
\hline \multirow[b]{2}{*}{ Compound } & \multirow{2}{*}{$\begin{array}{c}\text { Number } \\
\text { of } \\
\text { samples } \\
\text { analyzed }\end{array}$} & \multirow{2}{*}{$\begin{array}{c}\text { Number } \\
\text { of } \\
\text { detectlons }\end{array}$} & \multirow[b]{2}{*}{$\begin{array}{c}\text { Detection } \\
\text { level }\end{array}$} & \multicolumn{5}{|c|}{ Concentration at indicated percentlle } \\
\hline & & & & 10 & 25 & $\begin{array}{c}50 \\
\text { (median) }\end{array}$ & 75 & 90 \\
\hline \multicolumn{9}{|c|}{ Herbicides } \\
\hline \multicolumn{9}{|c|}{ Organonitrogen herbicides } \\
\hline Alachlor & 470 & 119 & 0.10 & $<0.10$ & $<0.10$ & $<0.10$ & 0.10 & 0.20 \\
\hline Ametryn & 473 & 53 & .10 & $<.10$ & $<.10$ & $<.10$ & $<.10$ & .10 \\
\hline Atrazine & 473 & 434 & .10 & .10 & .20 & .8 & 2.2 & 5.0 \\
\hline Bromacil & 439 & 10 & .10 & $<.10$ & $<.10$ & $<.10$ & $<.10$ & $<.10$ \\
\hline Butachlor & 439 & 2 & .10 & $<.10$ & $<.10$ & $<.10$ & $<.10$ & $<.10$ \\
\hline Carboxin & 439 & 0 & .10 & $<.10$ & $<.10$ & $<.10$ & $<.10$ & $<.10$ \\
\hline Cyanazine & 473 & 197 & .10 & $<.10$ & $<.10$ & $<.10$ & .10 & .30 \\
\hline Diphenamid & 439 & 0 & .10 & $<.10$ & $<.10$ & $<.10$ & $<.10$ & $<.10$ \\
\hline Hexazinone & 439 & 1 & .10 & $<.10$ & $<.10$ & $<.10$ & $<.10$ & $<.10$ \\
\hline Metolachlor & 470 & 237 & .10 & $<.10$ & $<.10$ & .10 & .20 & .60 \\
\hline Metribuzin & 470 & 29 & .10 & $<.10$ & $<.10$ & $<.10$ & $<.10$ & $<.10$ \\
\hline Prometone & 473 & 69 & .10 & $<.10$ & $<.10$ & $<.10$ & $<.10$ & .10 \\
\hline Prometryn & 473 & 0 & .10 & $<.10$ & $<.10$ & $<.10$ & $<.10$ & $<.10$ \\
\hline Propachlor & 439 & 17 & .10 & $<.10$ & $<.10$ & $<.10$ & $<.10$ & $<.10$ \\
\hline Propazine & 473 & 102 & .10 & $<.10$ & $<.10$ & $<.10$ & $<.10$ & .10 \\
\hline Simazine & 473 & 177 & .10 & $<.10$ & $<.10$ & $<.10$ & .10 & .20 \\
\hline Simetryn & 473 & 0 & .10 & $<.10$ & $<.10$ & $<.10$ & $<.10$ & $<.10$ \\
\hline Terbacil & 439 & 2 & .10 & $<.10$ & $<.10$ & $<.10$ & $<.10$ & $<.10$ \\
\hline \multirow[t]{2}{*}{ Trifluralin } & 470 & 5 & .10 & $<.10$ & $<.10$ & $<.10$ & $<.10$ & $<.10$ \\
\hline & \multicolumn{8}{|c|}{ Chlorophenoxy acid herbicides } \\
\hline $2,4-\mathrm{D}$ & 43 & 40 & .01 & .01 & .03 & .07 & .16 & .24 \\
\hline 2,4-DP & 43 & 0 & .01 & $<.01$ & $<.01$ & $<.01$ & $<.01$ & $<.01$ \\
\hline $2,4,5-\mathrm{T}$ & 43 & 1 & .01 & $<.01$ & $<.01$ & $<.01$ & $<.01$ & $<.01$ \\
\hline Silvex & 43 & 0 & .01 & $<.01$ & $<.01$ & $<.01$ & $<.01$ & $<.01$ \\
\hline \multicolumn{9}{|c|}{ Thiocarbamate herbicides } \\
\hline Butylate & 439 & 5 & .10 & $<.10$ & $<.10$ & $<.10$ & $<.10$ & $<.10$ \\
\hline Cycloate & 439 & 1 & .10 & $<.10$ & $<.10$ & $<.10$ & $<.10$ & $<.10$ \\
\hline Vernolate & 439 & 0 & .10 & $<.10$ & $<.10$ & $<.10$ & $<.10$ & $<.10$ \\
\hline
\end{tabular}


Table 21. Statistical summary of concentrations of herbicides and insecticides in water from streams in lower Kansas River Basin, Kansas and Nebraska, May 1987-February 1990-Continued

\begin{tabular}{|c|c|c|c|c|c|c|c|c|}
\hline \multirow[b]{2}{*}{ Compound } & \multirow{2}{*}{$\begin{array}{l}\text { Number } \\
\text { of } \\
\text { samples } \\
\text { analyzed }\end{array}$} & \multirow{2}{*}{$\begin{array}{c}\text { Number } \\
\text { of } \\
\text { detectlons }\end{array}$} & \multirow[b]{2}{*}{$\begin{array}{l}\text { Detection } \\
\text { level }\end{array}$} & \multicolumn{5}{|c|}{ Concentration at indicated percentlle } \\
\hline & & & & 10 & 25 & $\begin{array}{c}50 \\
\text { (medlan) }\end{array}$ & 75 & 90 \\
\hline \multicolumn{9}{|c|}{ Insecticides } \\
\hline \multicolumn{9}{|c|}{ Organochlorine Insecticides } \\
\hline Aldrin & 44 & 0 & 0.01 & $<0.01$ & $<0.01$ & $<0.01$ & $<0.01$ & $<0.01$ \\
\hline Chlordane & 42 & 3 & .10 & $<.10$ & $<.10$ & $<.10$ & $<.10$ & $<.10$ \\
\hline $\mathrm{DDD}$ & 44 & 0 & .01 & $<.01$ & $<.01$ & $<.01$ & $<.01$ & $<.01$ \\
\hline DDE & 44 & 0 & .01 & $<.01$ & $<.01$ & $<.01$ & $<.01$ & $<.01$ \\
\hline DDT & 42 & 1 & .01 & $<.01$ & $<.01$ & $<.01$ & $<.01$ & $<.01$ \\
\hline Dieldrin & 42 & 3 & .01 & $<.01$ & $<.01$ & $<.01$ & $<.01$ & $<.01$ \\
\hline Endosulfan & 42 & 0 & .01 & $<.01$ & $<.01$ & $<.01$ & $<.01$ & $<.01$ \\
\hline Endrin & 42 & 0 & .01 & $<.01$ & $<.01$ & $<.01$ & $<.01$ & $<.01$ \\
\hline Heptachlor & 44 & 1 & .01 & $<.01$ & $<.01$ & $<.01$ & $<.01$ & $<.01$ \\
\hline $\begin{array}{l}\text { Heptachlor } \\
\text { epoxide }\end{array}$ & 42 & 1 & .01 & $<.01$ & $<.01$ & $<.01$ & $<.01$ & $<.01$ \\
\hline Lindane & 42 & 3 & .01 & $<.01$ & $<.01$ & $<.01$ & $<.01$ & $<.01$ \\
\hline Methoxychlor & 42 & 2 & .01 & $<.01$ & $<.01$ & $<.01$ & $<.01$ & $<.01$ \\
\hline Mirex & 44 & 0 & .01 & $<.01$ & $<.01$ & $<.01$ & $<.01$ & $<.01$ \\
\hline Perthane & 42 & 0 & .10 & $<.10$ & $<.10$ & $<.10$ & $<.10$ & $<.10$ \\
\hline Toxaphene & 42 & 0 & 1.0 & $<1.0$ & $<1.0$ & $<1.0$ & $<1.0$ & $<1.0$ \\
\hline \multicolumn{9}{|c|}{ Organophosphorus insecticides } \\
\hline Diazinon & 44 & 10 & .01 & $<.01$ & $<.01$ & $<.01$ & $<.01$ & .02 \\
\hline Ethion & 44 & 0 & .01 & $<.01$ & $<.01$ & $<.01$ & $<.01$ & $<.01$ \\
\hline Malathion & 44 & 2 & .01 & $<.01$ & $<.01$ & $<.01$ & $<.01$ & $<.01$ \\
\hline $\begin{array}{l}\text { Methyl } \\
\text { parathion }\end{array}$ & 44 & 0 & .01 & $<.01$ & $<.01$ & $<.01$ & $<.01$ & $<.01$ \\
\hline Methyl trithion & 44 & 0 & .01 & $<.01$ & $<.01$ & $<.01$ & $<.01$ & $<.01$ \\
\hline Parathion & 44 & 1 & .01 & $<.01$ & $<.01$ & $<.01$ & $<.01$ & $<.01$ \\
\hline Trithion & 44 & 0 & .01 & $<.01$ & $<.01$ & $<.01$ & $<.01$ & $<.01$ \\
\hline \multicolumn{9}{|c|}{ Carbamate insecticides } \\
\hline 1-Naphthol & 43 & 0 & .50 & $<.50$ & $<.50$ & $<.50$ & $<.50$ & $<.50$ \\
\hline $\begin{array}{l}\text { 3-Hydroxycar- } \\
\text { bofuran }\end{array}$ & 43 & 0 & .50 & $<.50$ & $<.50$ & $<.50$ & $<.50$ & $<.50$ \\
\hline Aldicarb & 43 & 0 & .50 & $<.50$ & $<.50$ & $<.50$ & $<.50$ & $<.50$ \\
\hline $\begin{array}{l}\text { Aldicarb } \\
\text { sulfone }\end{array}$ & 43 & 0 & .50 & $<.50$ & $<.50$ & $<.50$ & $<.50$ & $<.50$ \\
\hline
\end{tabular}


Table 21. Statistical summary of concentrations of herbicides and insecticides in water from streams in lower Kansas River Basin, Kansas and Nebraska, May 1987-February 1990-Continued

\begin{tabular}{|c|c|c|c|c|c|c|c|c|}
\hline \multirow[b]{2}{*}{ Compound } & \multirow{2}{*}{$\begin{array}{c}\text { Number } \\
\text { of } \\
\text { samples } \\
\text { analyzed }\end{array}$} & \multirow{2}{*}{$\begin{array}{c}\text { Number } \\
\text { of } \\
\text { detectlons }\end{array}$} & \multirow[b]{2}{*}{$\begin{array}{c}\text { Detection } \\
\text { level }\end{array}$} & \multicolumn{5}{|c|}{ Concentration at indicated percentlle } \\
\hline & & & & 10 & 25 & $\begin{array}{c}50 \\
\text { (medlan) }\end{array}$ & 75 & 90 \\
\hline \multicolumn{9}{|c|}{ Carbamate insecticides_-Continued } \\
\hline $\begin{array}{l}\text { Aldicarb } \\
\text { sulfoxide }\end{array}$ & 43 & 0 & 0.50 & $<0.50$ & $<0.50$ & $<0.50$ & $<0.50$ & $<0.50$ \\
\hline Carbaryl . & 43 & 0 & .50 & $<.50$ & $<.50$ & $<.50$ & $<.50$ & $<.50$ \\
\hline Carbofuran & 43 & 0 & .50 & $<.50$ & $<.50$ & $<.50$ & $<.50$ & $<.50$ \\
\hline Methiocarb & 43 & 0 & .50 & $<.50$ & $<.50$ & $<.50$ & $<.50$ & $<.50$ \\
\hline Methomyl & 43 & 0 & .50 & $<.50$ & $<.50$ & $<.50$ & $<.50$ & $<.50$ \\
\hline Oxamyl & 43 & 0 & .50 & $<.50$ & $<.50$ & $<.50$ & $<.50$ & $<.50$ \\
\hline Propham & 43 & 0 & .50 & $<.50$ & $<.50$ & $<.50$ & $<.50$ & $<.50$ \\
\hline Propoxur & 43 & 0 & .50 & $<.50$ & $<.50$ & $<.50$ & $<.50$ & $<.50$ \\
\hline
\end{tabular}

trations were measured during June and July of 1989 when median concentrations exceeded the established MCL of $3.0 \mu \mathrm{g} / \mathrm{L}$. In August 1989, more than 25 percent of the samples contained atrazine concentrations that exceeded the established MCL. The median concentration of atrazine in May 1989 did not exceed the MCL, probably because the spring of 1989 was relatively dry and runoff from cropland was diminished. Analyses of these water samples also indicated that atrazine was the herbicide most frequently detected in stream water (95 percent of 173 samples), and in the largest concentrations (fig. 32). Following atrazine in order of decreasing frequency of detection and median concentrations were metolachlor (58 percent), cyanazine (40 percent), simazine (38 percent), and alachlor ( 24 percent). For atrazine, 17 percent of the samples exceeded the established MCL of $3.0 \mu \mathrm{g} / \mathrm{L}$; for simazine, no samples exceeded the established MCL of $4.0 \mu \mathrm{g} / \mathrm{L}$ (U.S. Environmental Protection Agency, 1992); and, for alachlor, 3.5 percent of the samples exceeded the established MCL of $2.0 \mu \mathrm{g} / \mathrm{L}$ (U.S. Environmental Protection Agency, 1992).

Seasonal variations of atrazine concentrations during March 1989 through February 1990 were markedly different between unregulated and regulated streams (fig. 33). Atrazine concentrations in the Delaware River near Muscotah, Kans. (station 72), an unregulated site upstream of Perry
Lake, were smallest (equal to or less than $0.2 \mu \mathrm{g} / \mathrm{L}$ ) in March and April before the herbicide was applied to the land and largest in spring and summer (May, June, and July) in response to herbicide application, precipitation, and subsequent runoff into the streams (fig. 33A). After atrazine concentrations at station 72 reached a peak of $22 \mu \mathrm{g} / \mathrm{L}$ in June 1989 , concentrations decreased to $0.2 \mu \mathrm{g} / \mathrm{L}$ in February 1990, regardless of the rates of streamflow, which were highest from late-August to mid-September. Similar patterns in unregulated streams were observed in the Big Blue River at Barneston, Nebr. (station 35) (fig. 33C) and the West Fork Big Blue River near Dorchester, Nebr. (station 23). A more detailed relation between atrazine concentrations and time and streamflow is shown in figure 34. Runoff-oriented water samples were collected from about mid-May to mid-June 1987, after atrazine had been applied to the land, at the West Fork Big Blue River near Dorchester, Nebr. (station 23), which drains $1,110 \mathrm{mi}^{2}$ of intensively cultivated cropland. Atrazine concentrations in these samples ranged from 1.7 to $18 \mu \mathrm{g} / \mathrm{L}$. Atrazine concentrations varied directly with fluctuations in streamflow, which indicates that atrazine is washed from the surface of the land into the streams as precipitation produces additional runoff. The largest concentrations of atrazine were measured just before or at the highest instantaneous streamflow rates. 


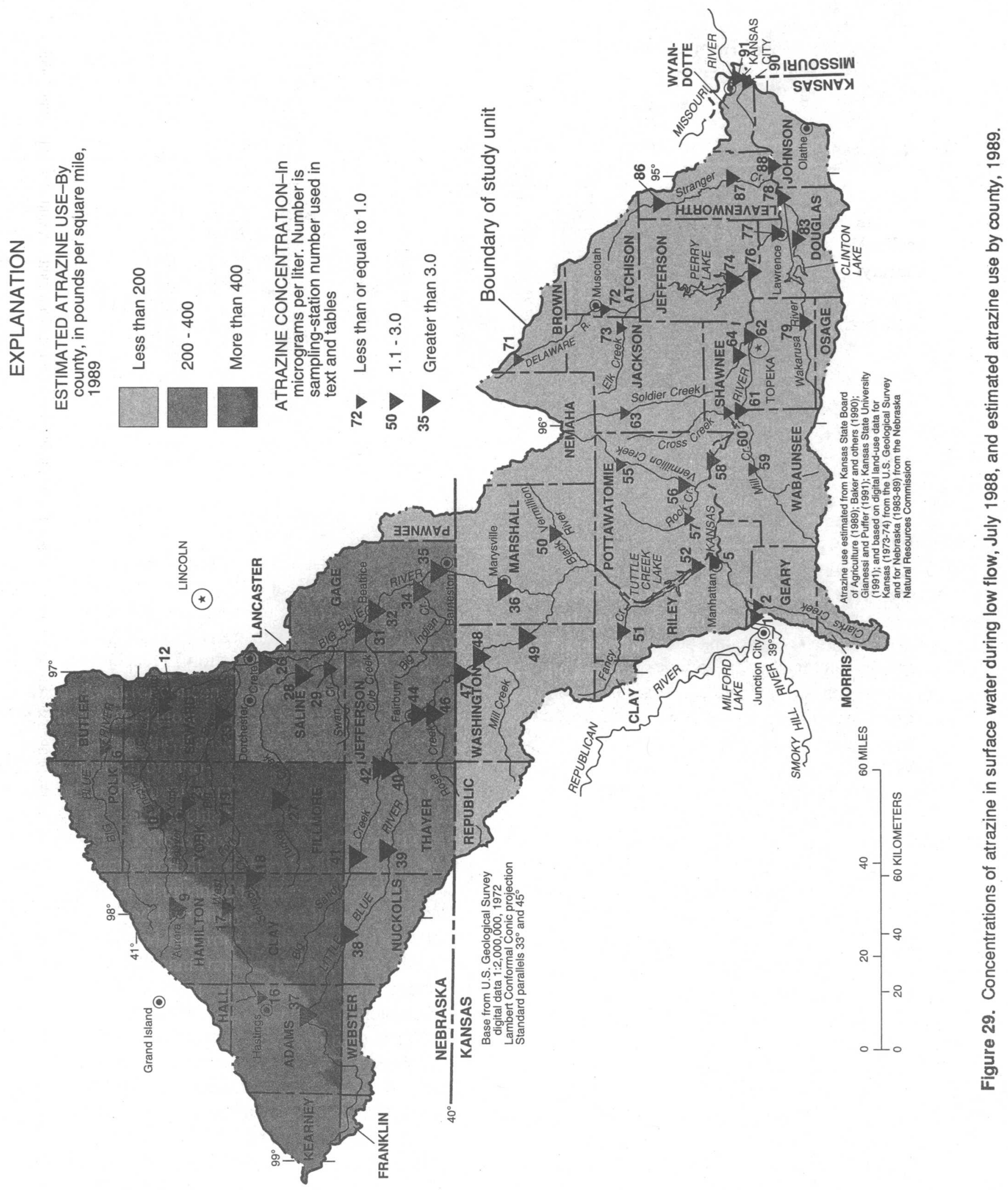

106 Surface-Water-Quality Assessment of the Lower Kansas River Basin, Kansas and Nebraska: Results of Investigations, 1987-90 

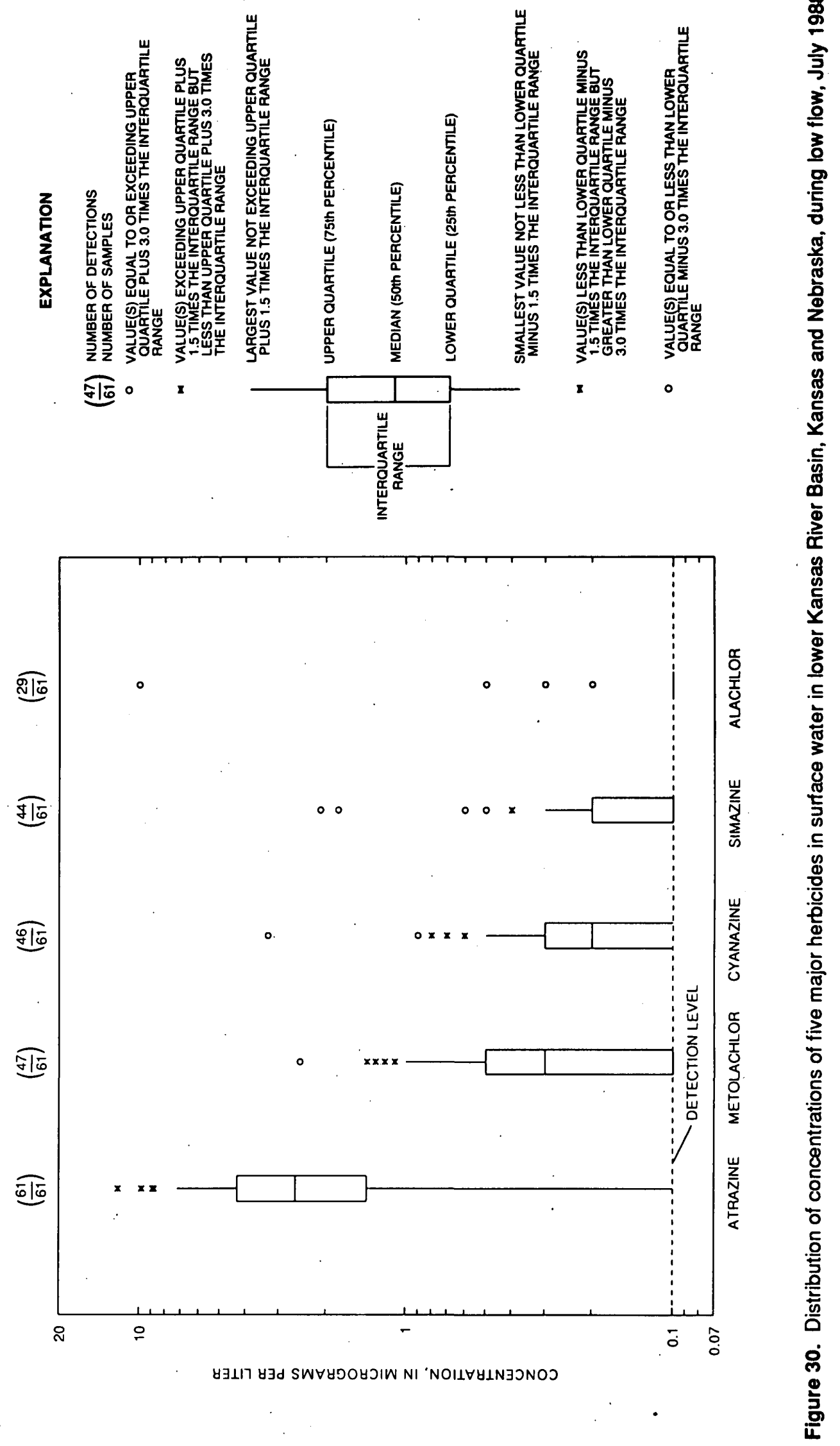

Water-Quality Conditions and Trends—-Herbicides and Insecticides 107 


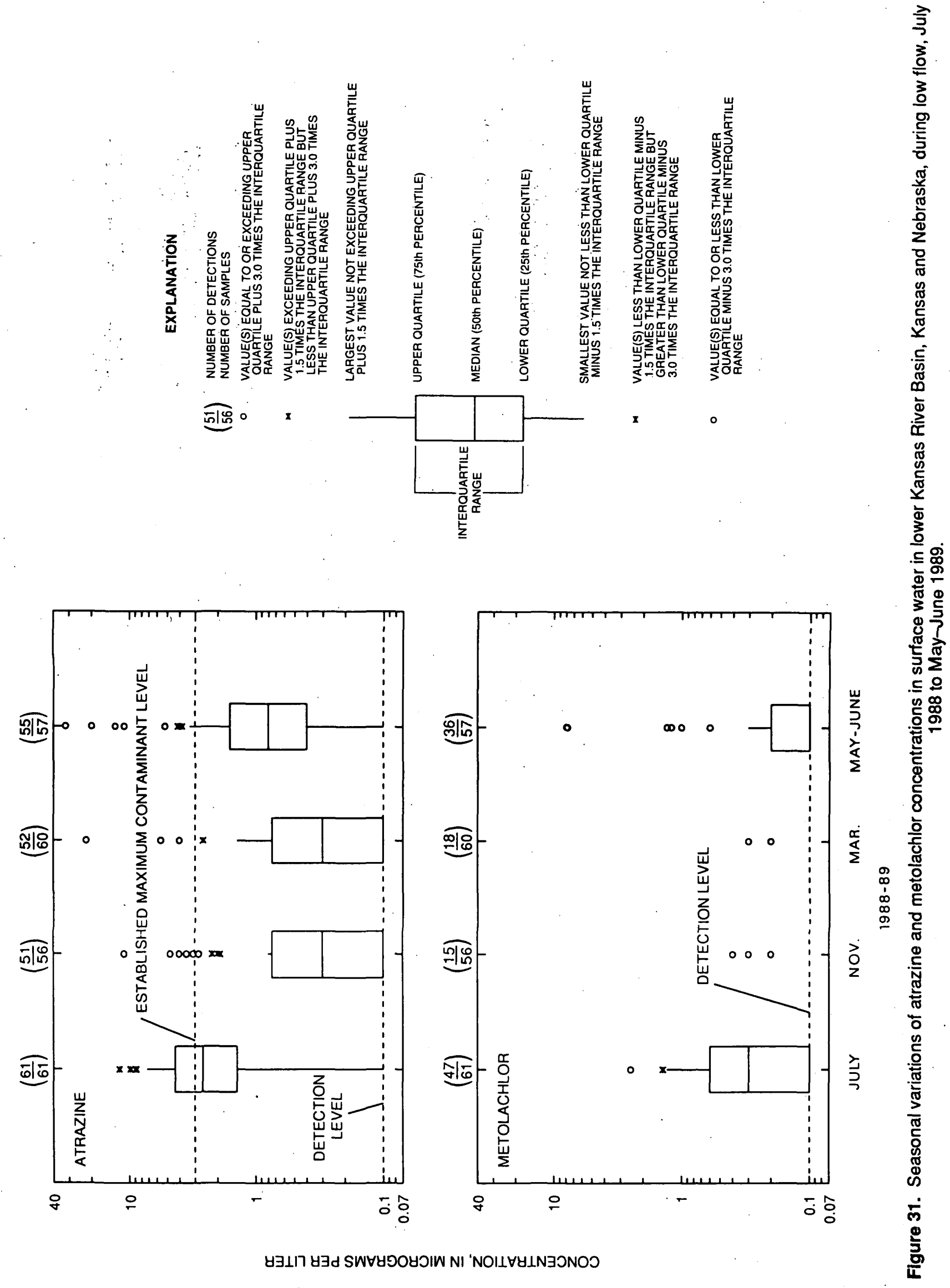



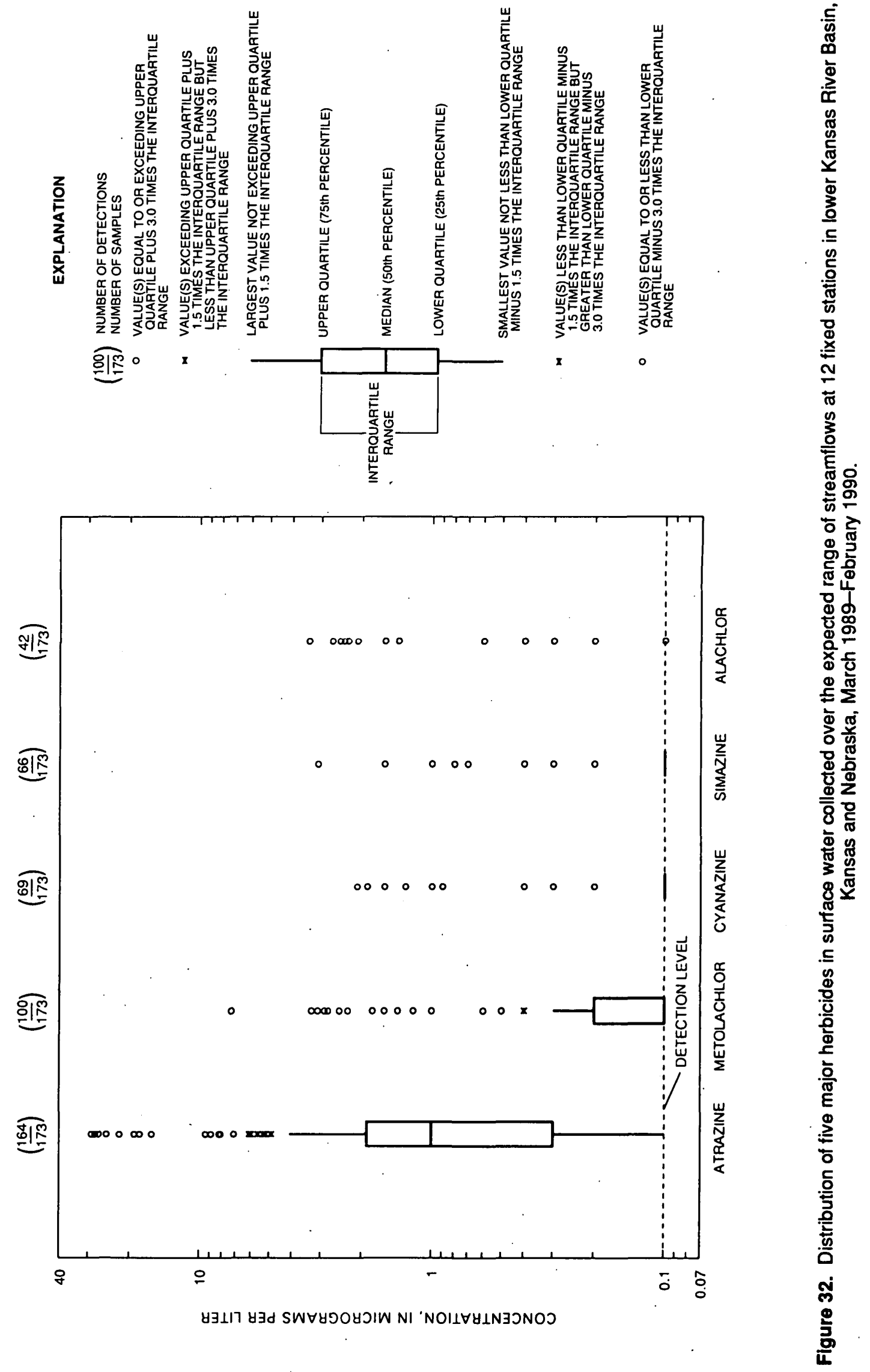

Water-Quality Conditions and Trends-Herbicides and Insecticides 109 


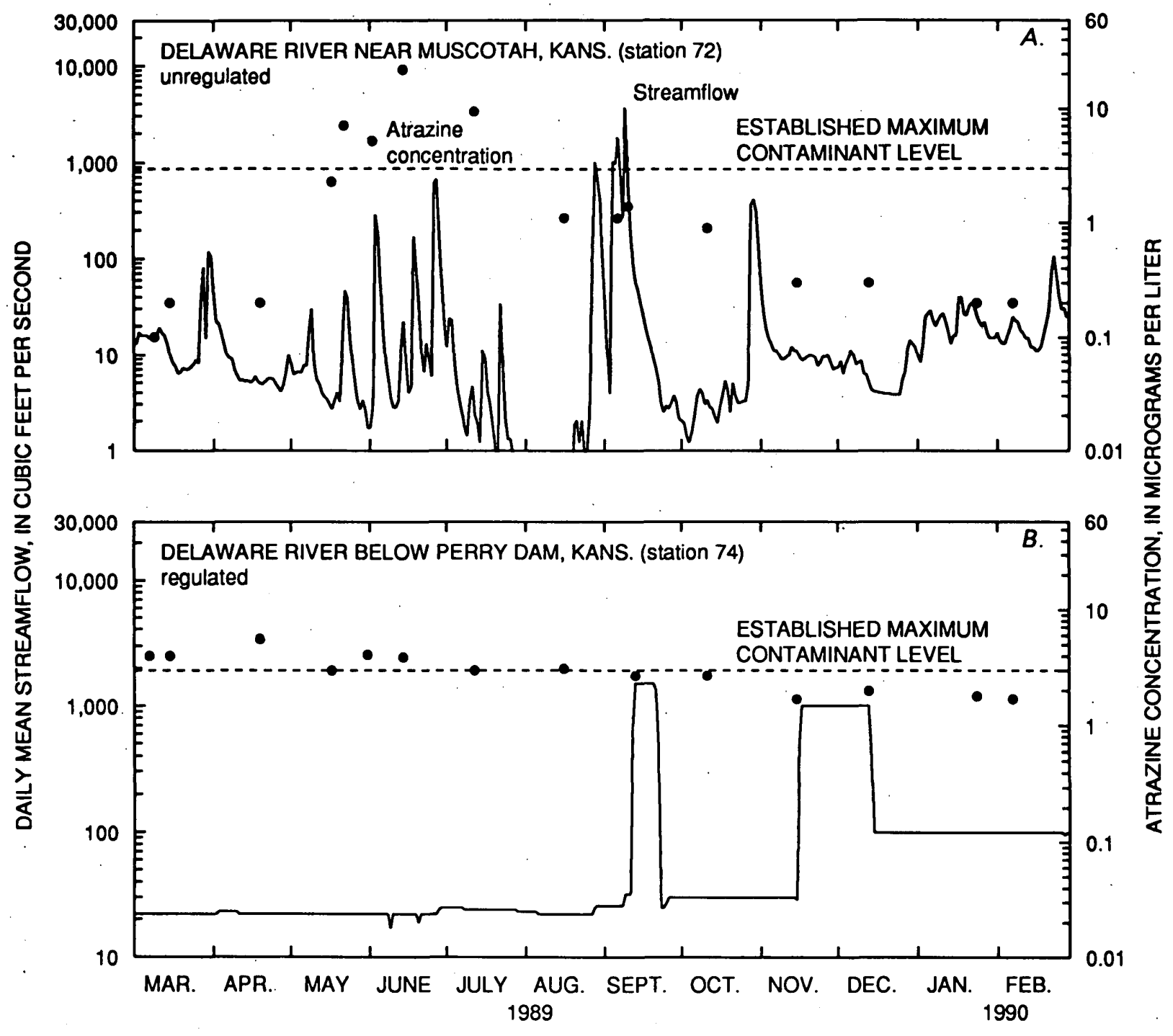

Figure 33. Concentrations of atrazine in water in unregulated and regulated reaches of Delaware and Big Blue Rivers, March 1989-February 1990.

Figures 33 and 34 show that large atrazine concentrations (10 to $20 \mu \mathrm{g} / \mathrm{L}$ ) were measured during May and June in unregulated principal streams that receive runoff from cropland where herbicide is applied.

In comparison to unregulated streams, atrazine concentrations measured in water samples from the Delaware River at the outflow of Perry Lake (station 74) showed little seasonal variability (fig. 33B). Concentrations of atrazine gradually decreased from $3.9 \mu \mathrm{g} / \mathrm{L}$ in June 1989 to $1.7 \mu \mathrm{g} / \mathrm{L}$ in February 1990 , and concentrations were equal to or greater than $3.0 \mu \mathrm{g} / \mathrm{L}$ from March through mid-
August 1989. The large volume of water in Perry Lake in relation to its outflow appeared to considerably decrease the seasonal variations in atrazine concentrations from inflowing streams. In contrast, analyses of outflow water samples from Tuttle Creek Lake (station 52) on the Big Blue River indicated some seasonal variation in atrazine concentrations (fig. 33D) because the volume of water in Tuttle Creek Lake was much smaller in relation to its outflow. For example, atrazine concentrations downstream of the outflow exceeded $3.0 \mu \mathrm{g} / \mathrm{L}$ in August and September 1989 in 


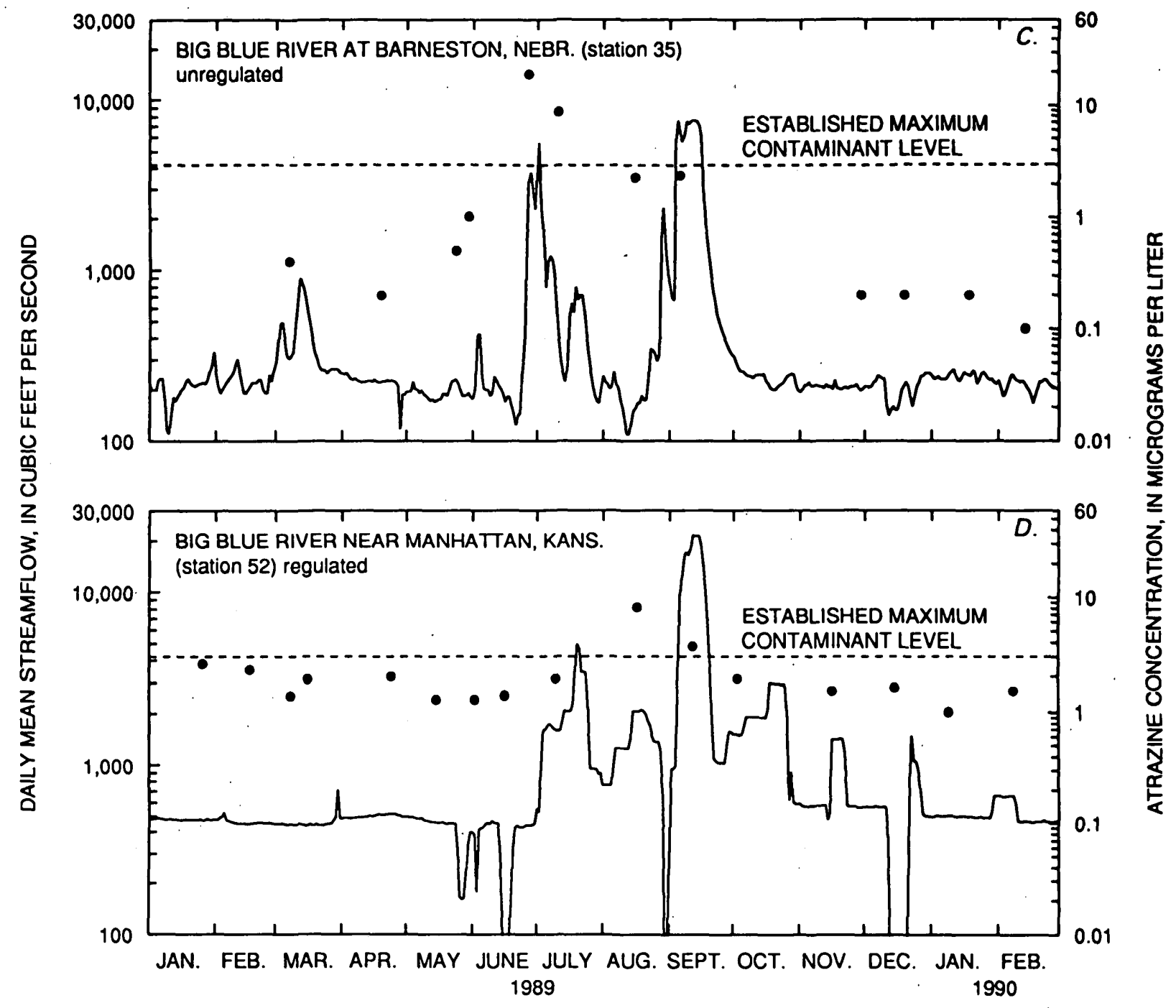

Figure 33. Concentrations of atrazine in water in unregulated and regulated reaches of Delaware and Big Blue Rivers, March 1989-February 1990-Continued

response to inflows containing large concentrations of atrazine in June and July.

It should be emphasized that conditions during March 1989 through February 1990 were relatively dry and that larger atrazine concentrations could occur during wet periods. For example, from April to October 1986, the median concentration of atrazine in the Big Blue River downstream from Tuttle Creek Lake (station 52) was $4.4 \mu \mathrm{g} / \mathrm{L}$, which was larger than the established MCL (Stamer and others, 1990). This median concentration was based on 10 samples, and the maximum concen- tration was $8.3 \mu \mathrm{g} / \mathrm{L}$. Because the Big Blue River often contributes a large percentage of the streamflow to the Kansas River during summer months, large concentrations of atrazine in the Big Blue River can cause atrazine concentrations in the Kansas River to increase to more than $3.0 \mu \mathrm{g} / \mathrm{L}$. Public-water supplies for Topeka, Lawrence, and the Kansas City, Kansas, metropolitan area are withdrawn from the Kansas River downstream from its confluence with the Big Blue River.

For the March 1989 through February 1990 sampling period, the mean of the monthly mean 


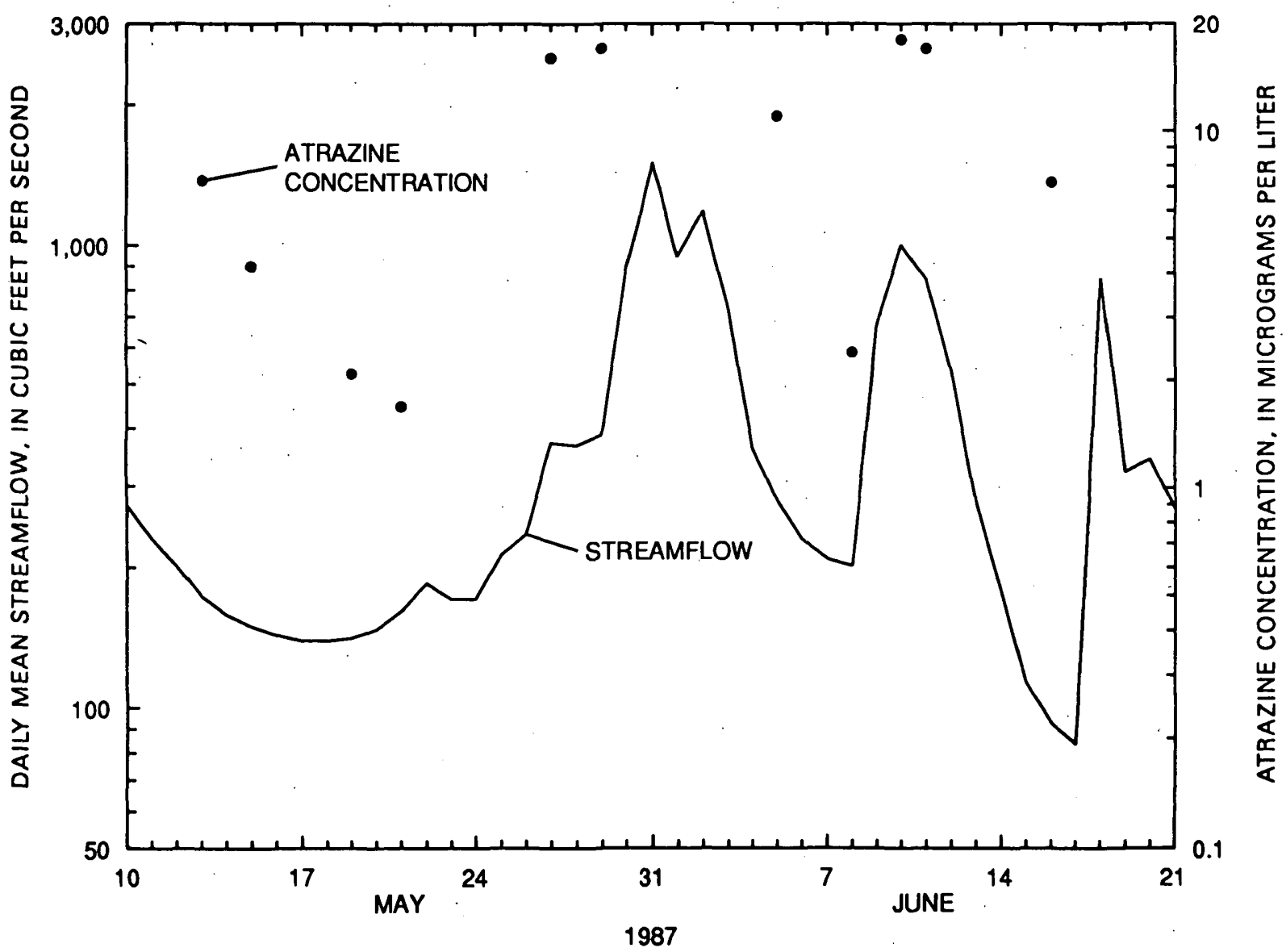

Figure 34. Daily mean streamflow and concentrations of atrazine in water from West Fork Big Blue River near Dorchester, Nebraska, May 10-June 21, 1987.

concentrations of atrazine at 1 of the 12 fixed stations (fig. 35) exceeded the established MCL of $3.0 \mu \mathrm{g} / \mathrm{L}$; the annual mean is the measure specified in the water-quality regulations (U.S. Environmental Protection Agency, 1991). Probable explanations for this exceedance, which was in the Big Blue River at Barneston, Nebr. (station 35), are that the land upstream is predominantly in row crops and that the drainage area upstream of the station is large $\left(4,427 \mathrm{mi}^{2}\right)$, which results in attenuated concentration peaks from smaller inflowing tributaries and permits large concentrations to persist for longer periods. The means of monthly mean atrazine concentrations in water from the Delaware River near Muscotah, Kans. (station 72), and the Delaware River below Perry Dam, Kans. (station 74), were 2.7 and $3.0 \mu \mathrm{g} / \mathrm{L}$, respectively, for the March 1989 through February 1990 sampling period. However, daily streamflow at the Muscotah station during this period was only 20 percent of the long-term mean. Thus, 1989-90 conditions probably represent relatively small atrazine concentrations in surface water, near normal or larger than normal streamflows could have resulted in much larger atrazine concentrations given current (1992) land-management practices and rates of atrazine application.

Studies have indicated that conventional watertreatment practices are ineffective in removing soluble herbicides, such as atrazine and alachlor, from finished water (Camey and others, 1991). Data collected as part of this study have shown that 


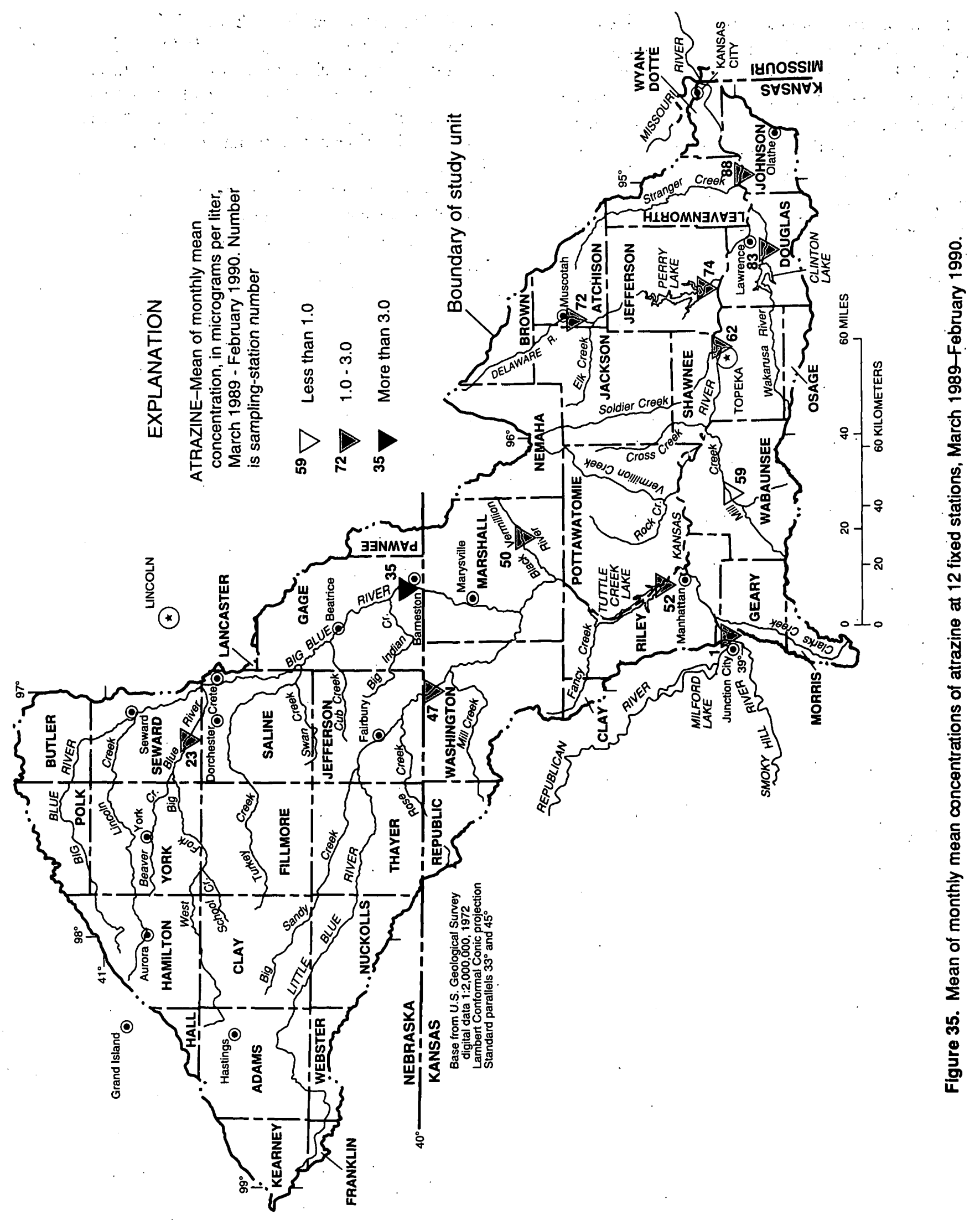


concentrations of organonitrogen herbicides, particularly atrazine, in surface water frequently exceed the U.S. Environmental Protection Agency's established MCL's for these compounds in finished water. Given current land-management practices and application rates, atrazine most likely will continue to be the pesticide detected most frequently and in the largest concentrations in surface water. This has implications for agricultural land-management and water-treatment practices.

\section{Chlorophenoxy-Acid and Thiocarbamate Herbicides}

Unlike the organonitrogen herbicides, the chlorophenoxy-acid herbicides are used exclusively in post-emergent applications. As shown in table 21, 2,4-D was the chorophenoxyacid herbicide that was most frequently detected in surface water. 2,4-D was detected in 40 (93 percent) of the 43 samples collected during the low-flow synoptic sampling surveys that were conducted in November 1988, March 1989, and May-June 1989; no low-flow survey was conducted for this class of herbicides in the summer. The largest concentrations were measured in the spring and fall and the smallest in the winter. However, the concentrations generally were small; the concentration at the 90 th percentile was $0.24 \mu \mathrm{g} / \mathrm{L}$, and the largest concentration was $0.60 \mu \mathrm{g} / \mathrm{L}$, which is substantially less than the MCL of $70 \mu \mathrm{g} / \mathrm{L}$ for $2,4-\mathrm{D}$ in finished public supplies (U.S. Environmental Protection Agency, 1992).

Butylate, which is a thiocarbamate herbicide, ranked sixth in usage in the study unit in 1989 (table 20); it is used as an incorporated preplant herbicide to control grassy weeds for corn production. Butylate was detected in only 5 of 439 water samples because thiocarbamate herbicides break down quickly in soils.

\section{Organochlorine Insecticides}

Organochlorine insecticides were the first class of insecticides to be developed and used (Smith and others, 1988). However, their production and use has decreased greatly because of their environmental persistence and accumulation in organisms. Many of the organochlorine insecticides have been banned from use in the United States (U.S. Environmental Protection Agency, 1985b). DDT was banned for agricultural use in 1973, dieldrin in 1974 , and chlordane in 1976. Organophosphorus and carbamate insecticides generally have replaced organochlorine insecticides in agricultural and urban uses.

Surface-water samples for organochlorine insecticides were collected during the synopticsampling surveys conducted in November 1988, March 1989, and May-June, 1989. As shown in table 21, few organochlorine insecticides were detected. Of the 640 samples analyzed, only 14 samples (2.2 percent) had detectable concentrations of organochlorine insecticides in water. This observation is consistent with both the decreased usage and small solubility of organochlorine insecticides in water. Concentrations, at the 90th percentile, of those organochlorine insecticides found to be present in surface water were all less than the detection level (less than $0.01,0.10$, or $1.0 \mu \mathrm{g} / \mathrm{L}$, depending on the compound). No samples contained concentrations of organochlorine insecticides that exceeded MCL's for public-water supplies. However, 12 of the 14 detected concentrations of organochlorine insecticides (chlordane, dieldrin, and lindane) were measured in Turkey Creek at Kansas City, Kans. (station 90, fig. 9), which drains one of the most urbanized areas in the study unit.

A synoptic-sampling survey for organochlorine insecticides in streambed sediment was conducted during an extended period of low flow at 60 stations in April 1989 (table 22). The analyses were done by the Tennessee Valley Authority Laboratory in Chattanooga, Tenn. Concentrations were reported at multiple detection levels, which generally ranged from 0.10 to $2.5 \mu \mathrm{g} / \mathrm{kg}$, because varying amounts of streambed material were extracted for analysis. Therefore, table 22 shows the number of samples analyzed, number of detections, and the range of detection levels by constituent. Because of the extensive use of many of these compounds in agriculture before their cancellation for use in this country and their environmental persistence, so few detections were unexpected. Most of the detections occurred in the lower reach of the Kansas River, located in the most urbanized area of the study unit.

From 1987 through 1989, samples of whole bottom-feeding fish tissue were collected at 
Table 22. Summary of detections of organochlorine insecticides in streambed sediment in lower Kansas River Basin, Kansas and Nebraska, during extended low flow, April 1989

\begin{tabular}{lccc}
\hline \multicolumn{1}{c}{ Compound } & $\begin{array}{c}\text { Number of } \\
\text { samples } \\
\text { analyzed }\end{array}$ & $\begin{array}{c}\text { Number of } \\
\text { detections }\end{array}$ & $\begin{array}{c}\text { Detection level } \\
\text { (mlcrograms } \\
\text { per kllogram) }\end{array}$ \\
\hline Aldrin & 60 & 0 & $0.10-2.5$ \\
alpha-BHC & 60 & 0 & $.10-2.5$ \\
Chlordane & 60 & 2 & $.10-2.5$ \\
P'P"DDE & 60 & 1 & $.10-2.5$ \\
P'P"DDT & 60 & 1 & $.10-2.5$ \\
& & & \\
Dieldrin & 60 & 0 & $.10-2.5$ \\
alpha-Endosulfan & 60 & 1 & $.10-2.5$ \\
Endrin & 60 & 1 & $.10-2.5$ \\
Heptachlor & 60 & 1 & $.10-2.5$ \\
Heptachlor epoxide & 60 & 1 & $.10-2.5$ \\
& &. & $.10-2.5$ \\
Lindane & 60 & 1 & $5.0-100$ \\
Toxaphene & 60 & 0 &
\end{tabular}

12 stations within the study unit. These data were collected as part of the Regional Ambient Fish Tissue Monitoring Program (RAFTMP) operated by the States of Kansas and Nebraska in cooperation with the U.S. Environmental Protection Agency. The spatial and temporal distribution of concentrations of organochlorine insecticides that exceed guidelines or action levels in whole bottomfeeding fish tissue is shown in figure 36. In general, where and when fish-tissue samples have been collected, concentrations of total cyclodiene insecticides (a group of organochlorine insecticides) in whole fish tissue have exceeded the National Academy of Sciences and the National Academy of Engineering guidelines for the protection of fish-eating birds and mammals (National Academy of Sciences and National Academy of Engineering, 1973). Of the fish-tissue data shown in figure 36, concentrations of cyclodiene insecticides detected in 23 of 25 fish-tissue samples exceeded the National Academy of Sciences and National Academy of Engineering (1973) guidelines, and concentrations of chlordane detected in 7 of 25 fish-tissue samples exceeded the U.S. Food and Drug Administration's (1989) action level of
0.3 parts per million (300 micrograms per kilogram).

The fish-tissue data shown in figure 36 show that exceedances of the U.S. Food and Drug Administration's (1989) action level for concentrations of chlordane in fish tissue were most commonly found in the lower reach of the Kansas River. This is the same reach in which organochlorine insecticides in streambed sediment were most commonly detected. The presence of chlordane in fish tissue in this reach of the Kansas River may be the result of its urban usage for termite control; this reach of the river is the most urbanized area of the study unit. This is supported by a study by the Kansas Department of Health and Environment (1987) that concluded fish downstream from urban areas along the Kansas River contained larger concentrations of chlordane than fish upstream from those urban areas.

\section{Organophosphorus and Carbamate Insecticides}

Organophosphorus and carbamate insecticides, in contrast to the organochlorine insecticides, generally are moderately soluble in water, are not persistent, and do not accumulate in organisms. 


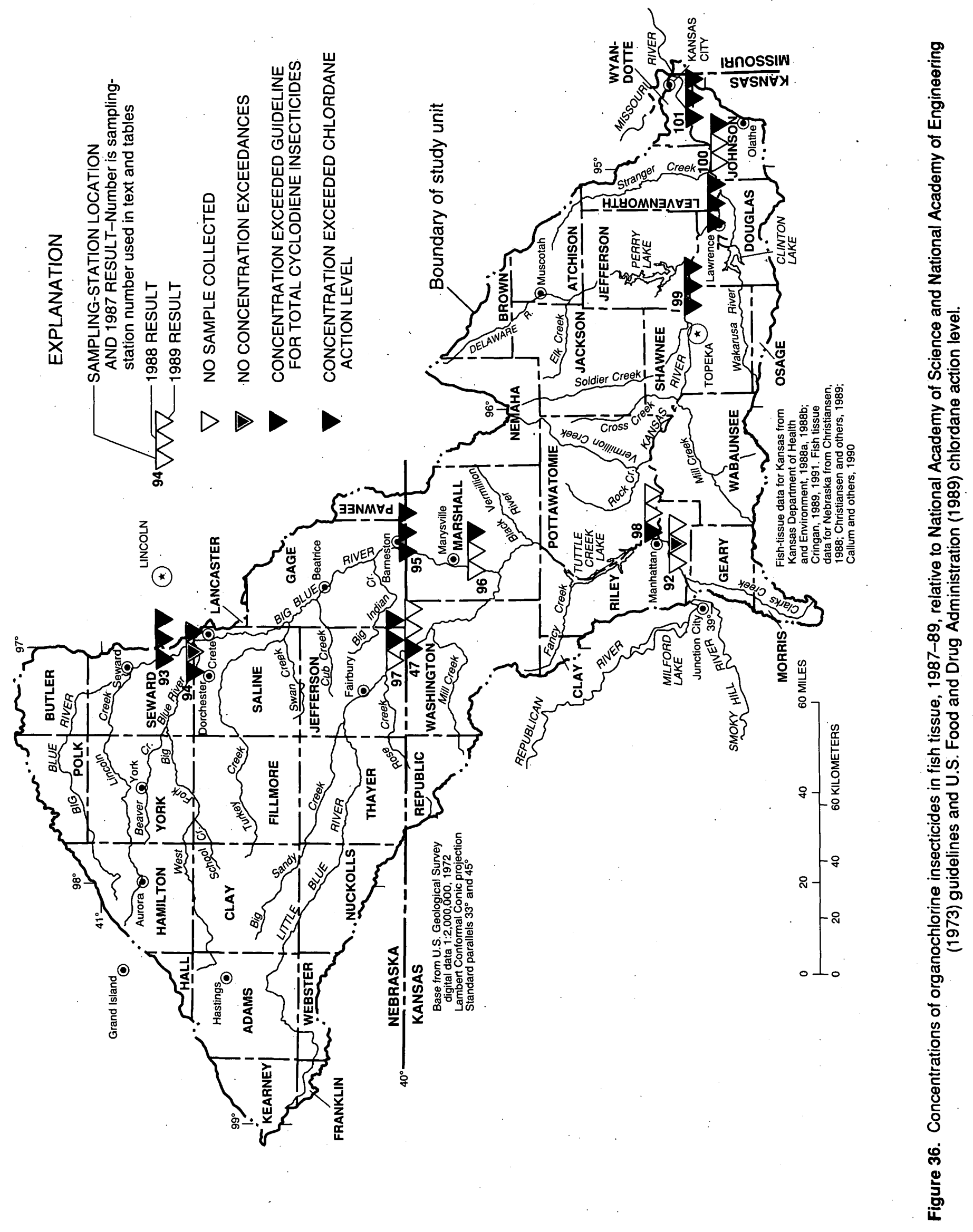


Samples for these two classes of insecticides were collected during the three low-flow synoptic sampling surveys in November 1988, March 1989, and May-June 1989. A statistical summary of the results is included in table 21 .

Diazinon was the organophosphorus insecticide that was detected most frequently (10 of 44 samples) and at the largest concentrations. The concentration of the 90 th percentile was $0.02 \mu \mathrm{g} / \mathrm{L}$; the largest concentration measured was $0.13 \mu \mathrm{g} / \mathrm{L}$, which is substantially less than the $0.6-\mu \mathrm{g} / \mathrm{L}$ lifetime Health Advisory Level established by the U.S. Environmental Protection Agency (1989) for finished drinking water. Diazinon is applied to soil to control insects in field crops and turf. Detections of Diazinon in the study unit appear to be associated with the control of insects in turf in urban settings. The largest concentrations measured $(0.05,0.12$, and $0.13 \mu \mathrm{g} / \mathrm{L})$ in each of the three low-flow synoptic-sampling surveys were in samples from Turkey Creek at Kansas City, Kans. (station 90, fig. 9), which drains a densely populated suburban area.

Carbamate insecticides break down very quickly in soil, as reflected by the lack of a single detection of these compounds in water samples collected in the study unit (table 21). However, samples for these compounds were not collected during the summer when they most likely were applied.

\section{Other Water-Quality Characteristics by J.O. Helgesen and J.K. Stamer}

This section of the report summarizes results for several water-quality characteristics not included in the previous sections. These characteristics are $\mathrm{pH}$, alkalinity, acidity, organic carbon, and radionuclides. Other data, generally collected only for a short time period at a limited number of stations, are not presented in this report but are included in data tabulated by Fallon and McChesney (1993). Those data include volatile organic compounds, acid base-neutral organic compounds, and cyanide in water and some trace elements and synthetic-organic compounds in streambed sediment.

\section{pH, Alkalinity, and Acidity}

An important factor affecting the chemical and biological quality of water in streams and lakes is $\mathrm{pH}$. $\mathrm{pH}$ is defined as the negative base-10 logarithm of hydrogen-ion activity measured in moles per liter (Hem, 1985). The $\mathrm{pH}$ of pure water at $25^{\circ} \mathrm{C}$ is 7.0 standard units; smaller values indicate acidic water, and larger values indicate alkaline water.

The alkalinity or acidity of water is its capacity to neutralize a strong acid or base (Hem, 1985). The principal source of alkalinity is atmospheric carbon dioxide. Alkalinity also is derived from the dissolution of rocks and minerals. Sedimentary rocks, which are abundant in the study unit, probably are the largest source of carbonate ions. Alkalinity is an important characteristic of water because it helps protect fish and other aquatic life from changes in pH due to photosynthesis or pointsource discharges. Alkalinity also may affect the suitability of water for municipal, industrial, and irrigation uses.

The principal sources of acidity can include solution of volcanic gases, oxidation of sulfidebearing minerals from mining operations, and acid rain. Natural rain has a pH of 5.6 standard units, which is acidic, but acid rain generally is defined as having a pH of less than 4.0 standard units. Acid rain is produced by the hydrolysis of nitrogen and sulfur oxides, which results, in part, from the burning of fossil fuel by thermoelectric powerplants, automobiles, and heating systems.

A statistical summary of $\mathrm{pH}$ and alkalinity data collected from the 13 fixed stations (table 4, fig. 9) during May 1987 through April 1990 is shown in table 23; acidity data are not applicable because no $\mathrm{pH}$ values less than 6.5 standard units were measured. These data are consistent with earlier (1978-86 water years) data, indicating that streams in the study unit generally were neutral to slightly alkaline and did not exhibit large variations in $\mathrm{pH}$ or alkalinity (Stamer, 1991a). For the 3-year sampling period, only two determinations of $\mathrm{pH}$ did not meet the chronic freshwater-aquatic criterion range of 6.5-9.0 standard units (U.S. Environmental Protection Agency, 1987). $\mathrm{pH}$ values of one sample from the Little Blue River at Hollenberg, Kans. (station 47) and one sample from the Kansas River at DeSoto, Kans. (station 88) slightly 
Table 23. Statistical summary of data on $\mathrm{pH}$, alkalinity, and organic carbon in water from fixed stations in lower Kansas River Basin, Kansas and Nebraska, May 1987-April 1990

Concentrations in milligrams per liter, except as noted; --; the 10- and 90-percentile values are not shown for stations having fewer than 30 analyses]

\begin{tabular}{|c|c|c|c|c|c|c|c|}
\hline \multirow{2}{*}{$\begin{array}{l}\text { Station } \\
\text { number } \\
\text { (flg. 9) }\end{array}$} & \multirow[b]{2}{*}{ Station name } & \multirow{2}{*}{$\begin{array}{c}\text { Number } \\
\text { of } \\
\text { analyses }\end{array}$} & \multicolumn{5}{|c|}{ Value at indicated percentlle } \\
\hline & & & 10 & 25 & $\begin{array}{l}50 \text { (me- } \\
\text { dlan) }\end{array}$ & 75 & 90 \\
\hline
\end{tabular}

$\mathrm{pH}$, in standard units

1 Kansas River at Fort Riley, Kans.

3 Kings Creek near Manhattan, Kans.

23 West Fork Big Blue River near Dorchester, Nebr.

35 Big Blue River at Barneston, Nebr.

47 Little Blue River at Hollenberg, Kans.

50 Black Vermillion River near Frankfort, Kans.

52 Big Blue River near Manhattan, Kans.

59 Mill Creek near Paxico, Kans.

62 Kansas River at Topeka, Kans.

72 Delaware River near Muscotah, Kans.

74 Delaware River below Perry Dam, Kans.

83 Wakarusa River near Lawrence, Kans.

88 Kansas River at DeSoto, Kans.
39

24

45

42

42

47

$\begin{array}{lr}7.8 & 8.2 \\ -- & 7.7\end{array}$

8.3

7.9

$\begin{array}{ll}7.3 & 7.8\end{array}$

8.1

8.3

8.3

8.0

48

43

44

44

43

43

39

39

44

Total alkalinity as $\mathrm{CaCO}_{3}$

1 Kansas River at Fort Riley, Kans.

3 Kings Creek near Manhattan, Kans.

23 West Fork Big Blue River near Dorchester, Nebr.

35 Big Blue River at Barneston, Nebr.

47 Little Blue River at Hollenberg, Kans.

50 Black Vermillion River near Frankfort, Kans.

52 Big Blue River near Manhattan, Kans.

59 Mill Creek near Paxico, Kans.

62 Kansas River at Topeka, Kans.

72 Delaware River near Muscotah, Kans.

74 Delaware River below Perry Dam, Kans.

83 Wakarusa River near Lawrence, Kans.

88 Kansas River at DeSoto, Kans.

$\begin{array}{rrrrrr}38 & 130 & 160 & 200 & 240 & 260 \\ 13 & -- & 270 & 290 & 290 & -. \\ 37 & 130 & 180 & 220 & 250 & 250 \\ 37 & 80 & 170 & 200 & 240 & 270 \\ 38 & 110 & 170 & 180 & 200 & 220 \\ & & & & & \\ 38 & 180 & 240 & 270 & 300 & 310 \\ 36 & 120 & 150 & 190 & 210 & 240 \\ 39 & 170 & 220 & 250 & 280 & 310 \\ 36 & 140 & 160 & 190 & 210 & 230 \\ 34 & 160 & 190 & 230 & 250 & 290 \\ & & & & & \\ 32 & 130 & 140 & 160 & 180 & 190 \\ 32 & 120 & 130 & 140 & 160 & 190 \\ 36 & 130 & 150 & 190 & 220 & 230\end{array}$


Table 23. Statistical summary of data on $\mathrm{pH}$, alkalinity, and organic carbon in water from fixed stations in lower Kansas River Basin, Kansas and Nebraska, May 1987-April 1990-Continued

\begin{tabular}{|c|c|c|c|c|c|c|c|}
\hline \multirow{2}{*}{$\begin{array}{c}\text { Station } \\
\text { number } \\
\text { (flg. 9) }\end{array}$} & \multirow[b]{2}{*}{ Station name } & \multirow{2}{*}{$\begin{array}{c}\text { Number } \\
\text { of } \\
\text { analyses }\end{array}$} & \multicolumn{5}{|c|}{ Value at indicated percentlle } \\
\hline & & & 10 & 25 & $\begin{array}{l}50 \text { (me- } \\
\text { dlan) }\end{array}$ & 75 & 90 \\
\hline \multicolumn{8}{|c|}{ Carbon, organic, dissolved } \\
\hline 1 & Kansas River at Fort Riley, Kans. & 38 & 4.4 & 4.6 & 5.2 & 5.8 & 6.0 \\
\hline 3 & Kings Creek near Manhattan, Kans. & 13 & -- & 1.3 & 1.5 & 2.4 & -- \\
\hline 23 & West Fork Big Blue River near Dorchester, Nebr. & 40 & 2.6 & 3.1 & 3.9 & 6.1 & 9.9 \\
\hline 35 & Big Blue River at Barneston, Nebr. & 37 & 3.7 & 4.2 & 5.0 & 7.0 & 8.3 \\
\hline 47 & Little Blue River at Hollenberg, Kans. & 36 & 2.3 & 2.6 & 3.8 & 5.4 & 7.8 \\
\hline 50 & Black Vermillion River near Frankfort, Kans. & 39 & 3.3 & 4.3 & 4.8 & 5.8 & 11 \\
\hline 52 & Big Blue River near Manhattan, Kans. & 36 & 3.5 & 4.0 & 4.4 & 5.3 & 5.9 \\
\hline 59 & Mill Creek near Paxico, Kans. & 38 & 2.0 & 2.3 & 2.9 & 4.0 & 4.9 \\
\hline 62 & Kansas River at Topeka, Kans. & 36 & 3.5 & 4.1 & 4.4 & 5.1 & 7.2 \\
\hline 72 & Delaware River near Muscotah, Kans. & 33 & 4.1 & 4.4 & 5.1 & 6.4 & 9.3 \\
\hline 74 & Delaware River below Perry Dam, Kans. & 32 & 4.1 & 4.3 & 4.5 & 5.0 & 5.8 \\
\hline 83 & Wakarusa River near Lawrence, Kans. & 32 & 4.3 & 4.6 & 4.8 & 5.5 & 7.2 \\
\hline 88 & Kansas River at DeSoto, Kans. & 37 & 4.0 & 4.4 & 5.0 & 5.8 & 7.0 \\
\hline \multicolumn{8}{|c|}{ Carbon, organic, suspended } \\
\hline 1 & Kansas River at Fort Riley, Kans. & 36 & .40 & .70 & 2.1 & 3.3 & 16 \\
\hline 3 & Kings Creek near Manhattan, Kans. & 13 & -- & .10 & .20 & .20 & -- \\
\hline 23 . & West Fork Big Blue River near Dorchester, Nebr. & 37 & .28 & .70 & 2.1 & 4.4 & 6.0 \\
\hline 35 & Big Blue River at Barneston, Nebr. & 34 & .70 & 1.6 & 3.0 & 4.9 & 5.0 \\
\hline 47 & Little Blue River at Hollenberg, Kans. & 37 & .40 & .75 & 1.7 & 5.0 & 10 \\
\hline 50 & Black Vermillion River near Frankfort, Kans. & 38 & .30 & .75 & 1.3 & 2.6 & 5.8 \\
\hline 52 & Big Blue River near Manhattan, Kans. & 34 & .30 & .47 & .80 & 1.2 & 2.2 \\
\hline 59 & Mill Creek near Paxico, Kans. & 38 & .29 & .40 & .75 & 1.4 & 5.3 \\
\hline 62 & Kansas River at Topeka, Kans. & 33 & .64 & .95 & 2.1 & 3.6 & 6.5 \\
\hline 72 & Delaware River near Muscotah, Kans. & 33 & .30 & .50 & 1.0 & 2.2 & 3.8 \\
\hline 74 & Delaware River below Perry Dam, Kans. & 31 & .32 & .40 & .50 & .90 & 1.1 \\
\hline 83 & Wakarusa River near Lawrence, Kans. & 32 & .33 & .50 & .90 & 1.5 & 1.6 \\
\hline 88 & Kansas River at DeSoto, Kans. & 37 & .68 & 1.1 & 2.4 & 3.7 & 8.8 \\
\hline
\end{tabular}


exceeded 9.0 standard units. All determinations of alkalinity met the chronic freshwater-aquatic criterion of not less than $20 \mathrm{mg} / \mathrm{L}$ (U.S. Environmental Protection Agency, 1987).

Data were adequate (periods of record of 10 years or more) to test for trends at 10 of the 13 fixed stations. Trend tests were not applied to alkalinity values because various field methods were used to determine alkalinity, affecting the comparability of results.

The results of the trend tests of flow-adjusted $\mathrm{pH}$ values are shown in table 24 . Results were statistically significant at 7 of the 10 stations; all those trends were positive, with average rates of change in $\mathrm{pH}$ ranging from 0.21 to 0.41 percent per year. Such trends could be associated with irrigation return flow, as discussed in the "Dissolved Solids and Major Ions" section in relation to increased concentrations of major ions. However, more definitive information to attribute the trends to specific human or natural factors is lacking.

\section{Organic Carbon}

Organic carbon in surface water generally consists of plant and animal debris and humic substances that enter streams and lakes. Additional sources of organic carbon are municipal- and industrial-wastewater discharges. The significance of organic carbon lies in its capability to: (1) deplete the amount of dissolved oxygen in water if the organic carbon is readily decomposable by aerobic bacteria; (2) form complexes with metals, increasing the mobility of those metals; (3) serve as a basic source of energy in the aquatic food chain; (4) cause taste, odor, or color problems in water; and (5) serve as a precursor to the formation of trihalomethane compounds, which result from chlorination in water-treatment processes.

Determinations of dissolved organic carbon (DOC) and suspended organic carbon (SOC) are summarized in table 23 for samples collected from May 1987 through April 1990 at the 13 fixed stations. According to Thurman (1985), DOC is chemically more reactive than SOC because it is organic matter that is in solution, whereas SOC may be composed of discrete plant or animal matter and organic coatings on silt and clay. Thus, DOC is more readily available to deplete dissolved oxygen, form complexes with metals, and serve as a precursor for trihalomethane formation.

Concentrations of organic carbon did not have large spatial variations throughout the study unit (table 23). For DOC, the range of median concentrations was 1.5 to $5.2 \mathrm{mg} / \mathrm{L}$, and the largest 90 th-percentile concentration was $11 \mathrm{mg} / \mathrm{L}$. SOC concentrations generally were smaller than DOC concentrations; for example, median concentrations varied from 0.20 to $3.0 \mathrm{mg} / \mathrm{L}$. Concentrations of SOC are partly a reflection of the quantities of suspended sediment carried by a stream because organic carbon can occur as sediment particles or as coatings on particles. Stamer (1991d) noted a relation between SOC and suspended-sediment concentrations by comparing 1978-89 data for the Big Blue River near Manhattan, Kans. (station 52), and the Kansas River at DeSoto, Kans. (station 88). Data for 1987-90 substantiates the relation; median SOC concentrations were $0.8 \mathrm{mg} / \mathrm{L}$ at the Manhattan station and $2.4 \mathrm{mg} / \mathrm{L}$ at the DeSoto station (table 23), the larger value being associated with larger quantities of suspended sediment being carried by the Kansas River (table 8 ).

Trend tests of organic-carbon concentrations were done for 1978-90 for the Big Blue River near Manhattan, Kans. (station 52), and the Kansas River at DeSoto, Kans. (station 88). Results did not indicate statistically significant trends in DOC or SOC concentrations through this period.

\section{Radionuclides}

Radionuclides in the environment are produced by the process of nuclear fission or may occur naturally. Radionuclides emit energy through structural changes in the atoms and, in the process, decay into other elements. The three principal forms of radionuclides that are important in the aquatic environment are: (1) alpha emitters, in which the energy consists of positively charged helium nuclei; (2) beta emitters, in which the energy consists of electrons or positrons; and (3) gamma emitters, in which the energy consists of electromagnetic wave-type energy similar to $\mathrm{X}$-rays.

In natural water, alpha-emitting radionuclides mainly are isotopes of radium and radon, which are products of the decay of uranium and thorium series (Hem, 1985). The isotopes of radium and 
Table 24. Trend-test results for $\mathrm{pH}$ of water from selected fixed stations in lower Kansas River Basin, Kansas and Nebraska

[Underlined $($ ), significant at 0.1 probability level; <, less than; results are flow-adjusted except for stations 52,74 , and 83 where flow was regulated directly by reservoir operation; calculated rate of change is percent of median per year]

\begin{tabular}{|c|c|c|c|c|c|}
\hline \multirow[b]{2}{*}{$\begin{array}{l}\text { Station } \\
\text { number } \\
\text { (fig. 9) }\end{array}$} & \multirow[b]{2}{*}{ Station name } & \multirow[b]{2}{*}{$\begin{array}{l}\text { Inclusive } \\
\text { years }\end{array}$} & \multirow[b]{2}{*}{$\begin{array}{l}\text { Number } \\
\text { of years }\end{array}$} & \multicolumn{2}{|c|}{$\begin{array}{c}\text { Results of seasonal } \\
\text { Kendall test for time } \\
\text { trend }\end{array}$} \\
\hline & & & & $\begin{array}{c}\text { Probability } \\
\text { level }\end{array}$ & $\begin{array}{l}\text { Calculated } \\
\text { rate of } \\
\text { change } \\
\text { (percent } \\
\text { per year) }\end{array}$ \\
\hline \multicolumn{6}{|c|}{ Common period } \\
\hline 23 & West Fork Big Blue R. near Dorchester, Nebr. & $1973-90$ & 18 & $<0.005$ & 0.42 \\
\hline 47 & Little Blue River at Hollenberg, Kans. & $1973-90$ & 18 & $<.005$ & 38 \\
\hline 52 & Big Blue River near Manhattan, Kans. & $1973-90$ & 18 & $<.005$ & 36 \\
\hline 74 & Delaware River below Perry Dam, Kans. & $1973-90$ & 18 & $<.005$ & 31 \\
\hline 88 & Kansas River at DeSoto, Kans. & $1973-90$ & 18 & $<, 005$ & 38 \\
\hline \multicolumn{6}{|c|}{ Longest available period } \\
\hline 3 & Kings Creek near Manhattan, Kans. & 1980-90 & 11 & .18 & -.37 \\
\hline 23 & West Fork Big Blue R. near Dorchester, Nebr & $1963-90$ & 28 & $<, 005$ & 23 \\
\hline 35 & Big Blue River at Barneston, Nebr. & $1980-90$ & 11 & .20 & .39 \\
\hline 52 & Big Blue River near Manhattan, Kans. & $1963-90$ & 28 & $<, 005$ & 21 \\
\hline 59 & Mill Creek near Paxico, Kans. & 1980-90 & 11 & .01 & 35 \\
\hline 62 & Kansas River at Topeka, Kans. & $1980-90$ & 11 & .90 & .05 \\
\hline 74 & Delaware River below Perry Dam, Kans. & $1969-90$ & 22 & $<.005$ & 36 \\
\hline 83 & Wakarusa River near Lawrence, Kans. & 1980-90 & 11 & 10 & 42 \\
\hline 88 & Kansas River at DeSoto, Kans. & $1953-90$ & 38 & $<.005$ & .22 \\
\hline
\end{tabular}

radon also can emit beta and gamma radiation. The importance of the occurrence of radionuclides in water is addressed by the National Interim Primary Drinking-Water Regulations (U.S. Environmental Protection Agency, 1986). The regulations specify maximum acceptable levels for gross-alpha ( $15 \mathrm{pCi} / \mathrm{L})$ and beta (4 millirems/yr) activity in general and, more specifically, the combined activity of radium-226 and -228 $(5 \mathrm{pCi} / \mathrm{L})$.

On the basis of limited available data, radionuclides do not appear to pose a problem in the study unit (Stamer, 1991c). During July 1987 through April 1989, from 3 to 8 samples were collected for radionuclide analysis at each of the
13 fixed stations (table 4, fig. 9). The significance of the results is not definitive because the results and the established criteria are expressed in various terms of concentration, activity, or dosage; conversion among these units may involve invalid assumptions (A.H. Mullin, U.S. Geological Survey, oral commun., 1992). In terms of the reported units, the following ranges were determined: dissolved gross alpha, from less than the detection level $(0.4 \mu \mathrm{g} / \mathrm{L})$ to $13 \mu \mathrm{g} / \mathrm{L}$ as natural uranium; suspended gross alpha, less than 0.4 to $27 \mu \mathrm{g} / \mathrm{L}$ as natural uranium; dissolved gross beta, 1.2 to $37 \mathrm{pCi} / \mathrm{L}$ as cesium-137; and suspended gross beta, less than 0.4 to $22 \mathrm{pCi} / \mathrm{L}$ as cesium-137. 


\section{SUMMARY}

Beginning in 1986, the U.S. Congress appropriated funds for the U.S. Geological Survey to test and refine concepts for a National Water-Quality Assessment (NAWQA) Program. The long-term goals of the program are to: (1) provide a nationally consistent description of current water-quality conditions for a large part of the Nation's water resources; (2) define long-term trends (or lack of trends) in water quality; and (3) identify, describe, and explain, as possible, the major factors that affect observed water-quality conditions and trends. As part of a pilot phase of the assessment program, the lower Kansas River Basin is one of seven study units that represent diverse hydrologic environments and water-quality conditions. This report summarizes results of the lower Kansas River Basin pilot study and focuses on analyses of data collected primarily by the U.S. Geological Survey from May 1987 through April 1990 to assess current surface-water-quality conditions and trends and their relation to natural and human factors.

The lower Kansas River Basin drains about $15,300 \mathrm{mi}^{2}$ in southeast Nebraska and northeast Kansas. The Kansas River is formed by the confluence of the Republican and Smoky Hill Rivers at Junction City, Kansas, and flows $170 \mathrm{mi}$ to its confluence with the Missouri River at Kansas City, Kansas. The study unit includes the Big Blue River subbasin in Nebraska and Kansas and other subbasins of smaller tributaries. About 85 percent of the study unit is agricultural land and is typical of the Midwestern United States agricultural region. Irrigation has increased severalfold in the past few decades in the Big Blue River subbasin.

Mean annual precipitation for 1951-80 ranged from about 24 in. in the northwest part of the basin to 36 in. in the southeast and produced mean annual runoff of less than 2 to almost 9 in. During the data-collection period of May 1987 through April 1990, below-normal precipitation resulted in less-than-normal runoff and streamflow in the study unit. During 1971-90, the mean flow rate of the Kansas River at its confluence with the Missouri River was about $8,200 \mathrm{ft}^{3} / \mathrm{s}$. About 70 percent of that flow was derived from within the study unit, and the remainder was contributed by the Republican and Smoky Hill Rivers. Water use in the study unit in 1990 totalled about 2.8 million acre-ft of which about 61 percent was from surface-water sources.

On the basis of established water-quality criteria, most streams in the lower Kansas River Basin were suitable for uses such as public-water supply, irrigation, and maintenance of aquatic life. However, most concerns recognized from the analysis of available data through 1986 (Jordan and Stamer, 1991) are substantiated by the analysis of data for May 1987 through April 1990. These concerns include: (1) upward trends in dissolved solids in the northwestern part of the study unit, which may result from irrigation; (2) large concentrations of dissolved solids in the main stem of the Kansas River due to chloride inflow from the Smoky Hill River; (3) large sediment yields in northeast Kansas due to erodible soils, row-crop production, and historically large precipitation and runoff; (4) large concentrations of the herbicide atrazine in surface water during the summer due to extensive use for com and sorghum production; and (5) large densities of fecal-indicator bacteria in the Big and Little Blue Rivers upstream of Tuttle Creek Lake that are derived from fecal material of livestock and from municipal-wastewater discharges. Nutrients, metals, trace elements, and radionuclides do not appear to pose any general water-quality problems in the study unit. Lessthan-normal precipitation and runoff during the data-collection period of 1987-90 affected surfacewater quality and are important factors in the interpretation of results.

Dissolved-solids concentrations in more than one-half of the samples from the main stem Kansas River during May 1987 through April 1990 exceeded $500 \mathrm{mg} / \mathrm{L}$. This concentration, the Secondary Maximum Contaminant Level (SMCL) established by the U.S. Environmental Protection Agency, may be of concern for public-water supplies and for the irrigation of sensitive crops. Surface water throughout the study unit was hard or very hard. Large concentrations of chloride in the Kansas River are derived from chlorideenriched ground water discharging from Permian formations in the Smoky Hill River Basin west of the study unit. In contrast, surface water originating within the study unit reflects the greater abundance of calcium carbonate in limestone and loess deposits, which comprise much of the surfi- 
cial and near-surface geology. Transport rates of dissolved solids within the study unit during 1987-90 were about 70 percent of rates during 1978-86, attributable mainly to smaller streamflow during the later period. Trend tests for dissolved solids, total hardness, and selected major ions for periods ending in 1990 showed results similar to trend tests for periods ending in 1986. Trends of increasing concentrations of some dissolved major ions were statistically significant in the Big Blue River subbasin, which could reflect substantial increases in irrigated acreage.

The largest concentrations of suspended sediment in streams during May 1987 through April 1990 were associated with high-density irrigated cropland in areas of little local relief and mediumdensity irrigated cropland in more dissected areas. The smallest concentrations were measured downstream from large reservoirs and in streams draining areas having little or no row-crop cultivation. Differences in particle size of suspended sediment were small among sampling stations. Suspendedsediment concentrations in relation to streamflow rate followed a consistent seasonal pattern; after accounting for the effect of flow, concentrations were typically smallest during January and February and largest during July and August. Mean annual suspended-sediment transport rates in the main stem Kansas River from May 1987 through April 1990 increased substantially in the downstream direction. Because of abnormally dry climatic conditions and large uncertainty factors in the results of some computations, no conclusions could be reached concerning the relations of suspended-sediment transport rate or yield to natural and human factors. Tests for trends in flow-adjusted suspended-sediment concentrations at five sampling stations resulted in one statistically significant downward trend for 1963-90 and one statistically significant upward trend for 1977-90. The trend-test results could not be explained by data on cropland removed from production or the effect of detention structures.

The largest sources of nitrogen and phosphorus in the study unit were fertilizer and livestock. Nitrate-nitrogen concentrations in stream-water samples did not exceed the 10-mg/L Maximum Contaminant Level (MCL) established by the U.S. Environmental Protection Agency for publicdrinking water supplies. Large concentrations in the Big Blue River subbasin were associated with fertilizer application. Ammonia and organicnitrogen concentrations generally were largest in streams in the Big Blue River subbasin and in the Kansas City, Kansas, urbanized area; sources include municipal wastewater, fertilizer, and livestock. Phosphorus concentrations frequently exceeded values recommended by the U.S. Environmental Protection Agency for minimizing the potential of eutrophication $(0.1 \mathrm{mg} / \mathrm{L})$. Concentrations of total phosphorus were much smaller downstream of reservoirs than upstream, as the reservoirs trap suspended sediment that may contain particulate phosphorus. Concentrations of total phosphorus generally were much larger in the upper part of the study unit than in the lower part, which probably relates to greater prevalence of cultivated land, fertilizer application, and livestock wastes.

Dissolved-oxygen (DO) concentrations were determined in July 1988 under maximum stress (that is, high water temperature, low streamflow, and predawn conditions). Five of 31 stations had DO concentrations less than the $5.0-\mathrm{mg} / \mathrm{L}$ minimum warmwater criterion for early aquatic life stages as established by the U.S. Environmental Protection Agency, and 4 of these 5 stations had concentrations less than the $3.0-\mathrm{mg} / \mathrm{L}$ criterion for all other life stages. Concentrations of DO less than the water-quality criteria were localized occurrences and do not reflect regional differences in DO distribution. The most severe DO deficiencies were the result of discharges from wastewater-treatment plants into small tributary streams with inadequate assimilative capacity. Even in the absence of wastewater discharge, algal respiration and inadequate reaeration associated with small streamflow may cause localized deficiencies in DO concentrations.

Densities of the fecal-indicator bacterium, Escherichia coli (E. coli), showed large regional differences within the study unit, based on a July 1988 survey. Densities at 84 percent of the stations in the Big Blue River subbasin exceeded the U.S. Environmental Protection Agency criterion of $576 \mathrm{col} / 100 \mathrm{~mL}$ for infrequently used full-body contact recreation, and 53 percent exceeded the 2,000-col/100 mL fecal coliform criterion for uses other than full-body contact established by the Kansas Department of Health and Environment. 
The largest densities of $E$. coli in the study unit were the result of discharges from municipal wastewater-treatment plants; however, densities in the Big Blue and Little Blue subbasins generally were larger than those in the Kansas River subbasin because of the greater transport of fecal material from domestic livestock in these two subbasins.

Most metals and trace elements were present only in small concentrations in the dissolved phase. Median concentrations of dissolved lithium and strontium generally were largest in water from three sampling stations on the main stem Kansas River, decreased in the downstream direction, and decreased with the increased streamflow at the Fort Riley sampling station. The source of lithium and strontium probably was saline ground-water discharge to the Smoky Hill River upstream of the study unit. Concentrations of suspended arsenic, chromium, lead, and other trace elements tended to be relatively large immediately downstream of large reservoirs in the study unit. Turbulence near the dams or the release of water from near the bottom of the reservoir may have caused these large suspended concentrations. Concentrations of elements in streambed sediment at several sampling stations may be related to wastewatertreatment or industrial activities.

Atrazine, the most extensively applied herbicide in the study unit, was detected most frequently and in the largest concentrations in samples of stream water collected from May 1987 through February 1990. In general, the largest concentrations of atrazine were measured where the largest quantities of atrazine were applied to the land. Following atrazine, in order of decreasing frequency of detection and magnitude of the median herbicide concentration, were metolachlor, cyanazine, simazine, and alachlor. Large atrazine concentrations, 10 to $20 \mu \mathrm{g} / \mathrm{L}$, were measured most frequently in unregulated principal streams during May and June. Downstream of reservoirs, the seasonal variability of atrazine concentrations was decreased compared to that of inflowing streams; however, concentrations downstream of reservoirs during the summer commonly exceeded the $3.0 \mu \mathrm{g} / \mathrm{L}$ MCL established by the U.S. Environmental Protection Agency. A chlorophenoxy-acid herbicide, 2,4-D, was detected in 40 (93 percent) of . 43 stream-water samples collected during three low-flow surveys. The largest concentration was $0.60 \mu \mathrm{g} / \mathrm{L}$, which is substantially less than the U.S. Environmental Protection Agency's MCL of $70 \mu \mathrm{g} / \mathrm{L}$ for finished water supplies. Organochlorine insecticides were detected in only 14 (2.2 percent) of 640 stream-water samples, and none of the concentrations exceeded established MCL's.

\section{REFERENCES CITED}

Arbogast, B.F., ed., 1990, Quality assurance manual for the U.S. Geological Survey's Branch of Geochemistry: U.S. Geological Survey Open-File Report 90-668, 184 p.

Baker, Maurice, Peterson, Nancy, and Kamble, S.T., 1990, Pesticide use on crops in Nebraska-1987: Lincoln, University of Nebraska Agricultural Research Division, 34 p.

Bevans, H.E., 1991, Pesticides and other syntheticorganic compounds, in Jordan, P.R., and Stamer, J.K., eds., Surface water-quality assessment of the lower Kansas River Basin, Kansas and NebraskaAnalysis of available data through 1986: U.S. Geological Survey Open-File Report 91-75, p. 138-152.

Britton, L.J., and Greeson, P.E., 1987, Methods for collection and analysis of aquatic biological and microbiological samples: U.S. Geological Survey Techniques of Water-Resources Investigations, book 5, Laboratory Analysis, chap. A4, 363 p.

Buol, S.W., Hole, F.D., and McCracken, R.J., 1980, Soil genesis and classification ( $2 \mathrm{~d}$ ed.): Ames, The Iowa State University Press, 404 p.

Callam, Michael, Lund, John, Brakhage, Paul, and Bazata, Ken, 1990, Findings of the 1989 Regional Ambient Fish Tissue Monitoring Program (RAFTMP), follow-up and special survey sites in Nébraska: Lincoln, Department of Environmental Control, State of Nebraska, 20 p.

Carney, Edward, Butler, M.K., and Hays, Eva, 1991, Atrazine in Kansas (2d ed.): Topeka, Kansas Department of Health and Environment, $34 \mathrm{p}$.

Christiansen, C.C., 1988, Findings of the 1987 Regional Ambient Fish Tissue Monitoring Program (RAFTMP) in Nebraska: Lincoln, Nebraska Department of Environmental Control, 34 p. 
Christiansen, C.C., Lund, John, Bazata, Ken, Brakhage, Paul, and Bubb, David, 1989, Findings of the 1988 Regional Ambient Fish Tissue Monitoring Program (RAFTMP) and follow-up survey in Nebraska: Lincoln, Nebraska Department of Environmental Control, 45 p.

Cringan, M.S., 1989, Regional Ambient Fish Tissue Monitoring Program (RAFTMP) and Kansas Follow-up Studies Program (KFSP)_-1988 summary report: Topeka, Kansas Department of Health and Environment, $25 \mathrm{p}$. 1991, Regional Ambient Fish Tissue Monitoring Program (RAFTMP) and Kansas Follow-up Studies Program (KFSP)_-1989 summary report: Topeka, Kansas Department of Health and Environment, 33 p.

Dreeszen, V.H., Reed, E.C., Burchett, R.R., and Prichard, G.E., 1973, Bedrock geologic map showing thickness of overlying Quaternary deposits, Grand Island quadrangle, Nebraska and Kansas: U.S. Geological Survey Miscellaneous Geologic Investigations Map I-819, 1 sheet, scale $1: 250,000$.

Dugan, J.T., 1984, Hydrologic characteristics of Nebraska soils: U.S. Geological Survey Water-Supply Paper 2222, 19 p.

Dugan, J.T., Engberg, R.A., and Jordan, P.R., 1991, Description of lower Kansas River Basin, in Jordan, P.R., and Stamer, J.K., eds., Surface water-quality assessment of the lower Kansas River Basin, Kansas and Nebraska-Analysis of available data through 1986: U.S. Geological Survey Open-File Report 91-75, p. 10-20.

Dugan, J.T., and Peckenpaugh, J.M., 1985, Effects of climate, vegetation, and soils on consumptive water use and ground-water recharge to the Central Midwest regional aquifer system, mid-continent United States: U.S. Geological Survey WaterResources Investigations Report 85-4236, 78 p.

Durfor, C.N., and Becker, Edith, 1964, Public water supplies of the 100 largest cities in the United States, 1962: U.S. Geological Survey WaterSupply Paper 1812, 364 p.

Ellis, M.J., 1981, Analysis of stream-aquifer system interrelationships in the Big Blue and Little Blue River basins in Gage and Jefferson Counties, Nebraska: U.S. Geological Survey WaterResources Investigations 81-29, 49 p.

Fader, S.W., 1974, Ground water in the Kansas River valley, Junction City to Kansas City, Kansas: Kansas Geological Survey Bulletin 206, part 2, $12 \mathrm{p}$.

Fallon, J.D., and McChesney, J.A., 1993, Surface-waterquality assessment of the lower Kansas River
Basin, Kansas and Nebraska-Project data, November 1986 through April 1990: U.S. Geological Survey Open-File Report 93-51, 594 p.

Fenneman, N.M., 1946, Physical divisions of the United States: Washington, D.C., U.S. Geological Survey special map, 1 sheet, scale 1:7,000,000.

Fishman, M.J., and Friedman, L.C., 1989, Methods for determination of inorganic substances in water and fluvial sediments: U.S. Geological Survey Techniques of Water-Resources Investigations, book 5, chap. A1, 545 p.

Fromm, Carla, and Wilk, Sally, eds., 1988, Kansas water-quality assessment 1986-87: Topeka, Kansas Department of Health and Environment 305(b) Report, 144 p.

Geological Society of America, 1959, Glacial map of the United States east of the Rocky Mountains: New York, Geological Society of America, 1 sheet, scale 1:1,750,000.

Gianessi, L.P., 1986, Water pollutant discharge and pesticide usage estimates for NAWQA surface water study regions: Washington, D.C., Resources for the Future, Renewable Resources Division, 18 p., unpaginated appendix.

Gianessi, L.P., and Puffer, C.M., 1991, Herbicide use in the United States: Washington, D.C., Resources for the Future, $128 \mathrm{p}$.

Gillespie, J.B., and Hargadine, G.D., 1981, Saline ground-water discharge to the Smoky Hill River between Salina and Abilene, central Kansas: U.S. Geological Survey Water-Resources Investigations 81-43, $71 \mathrm{p}$.

Gilliom, R.J., Alexander, R.B., and Smith, R.A., 1985, Pesticides in the Nation's rivers, 1975-1980, and implications for future monitoring: U.S. Geological Survey Water-Supply Paper 2271, 26 p.

Goerlitz, D.F., and Brown, Eugene, 1972, Methods for analysis of organic substances in water: U.S. Geological Survey Techniques of WaterResources Investigations, book 5, chap. A3, 40 p.

Goodman, T.A., Wilson, R.M., and Jordan, P.R., 1991a, Fecal-indicator bacteria, in Jordan, P.R., and Stamer, J.K., eds., Surface water-quality assessment of the lower Kansas River Basin, Kansas and Nebraska-Analysis of available data through 1986: U.S. Geological Survey Open-File Report 91-75, p. 153-160.

Goodman, T.R., Wilson, R.M., and Kelly, T.J., 1991b, Aquatic biological community, in Jordan, P.R., and Stamer, J.K., eds., Surface water-quality assessment of the lower Kansas River Basin, Kansas and Nebraska-Analysis of available data through 1986: U.S. Geological Survey Open-File Report 91-75, p. 161-167. 
Guy, H.P., and Norman, V.W., 1970, Field methods for measurement of fluvial sediment: U.S. Geological Survey Techniques of Water-Resources Investigations, book 3, chap. $\mathrm{C} 2,59 \mathrm{p}$.

Hem, J.D., 1985, Study and interpretation of the chemical characteristics of natural water ( $3 \mathrm{~d}$ ed.): U.S. Geological Survey Water-Supply Paper 2254, $263 \mathrm{p}$.

Hirsch, R.M., Alley, W.M., and Wilber, W.G., 1988, Concepts for a National Water-Quality Assessment Program: U.S. Geological Survey Circular 1021, $42 \mathrm{p}$.

Hirsch, R.M., Slack, J.R., and Smith, R.A., 1982, Techniques of trend analysis for monthly water quality data: Water Resources Research, v. 18, no. 1, p. 107-121.

Jordan, P.R., 1991a, Assessment approach, in Jordan, P.R., and Stamer, J.K., eds., Surface water-quality assessment of the lower Kansas River Basin, Kansas and Nebraska-Analysis of available data through 1986: U.S Geological Survey Open-File Report 91-75, p. 21-24. 1991b, Sources and characteristics of available surface water-quality data, in Jordan, P.R., and Stamer, J.K., eds., Surface water-quality assessment of the lower Kansas River Basin, Kansas and Nebraska-Analysis of available data through 1986: U.S. Geological Survey Open-File Report 91-75, p. 25-30. 1991c, Streamflow, in Jordan, P.R., and Stamer, J.K., eds., Surface water-quality assessment of the lower Kansas River Basin, Kansas and NebraskaAnalysis of available data through 1986:

U.S. Geological Survey Open-File Report 91-75, p. 31-33. 1991d, Dissolved solids and major ions, in Jordan, P.R., and Stamer, J.K, eds., Surface water-quality assessment of the lower Kansas River Basin, Kansas and Nebraska-Analysis of available data through 1986: U.S. Geological Survey Open-File Report 91-75, p. 42-69.

$1991 \mathrm{l}$, Suspended sediment, in Jordan, P.R., and Stamer, J.K., eds., Surface water-quality assessment of the lower Kansas River Basin, Kansas and Nebraska-Analysis of available data through 1986: U.S. Geological Survey Open-File Report 91-75, p. 70-77.

Jordan, P.R., and Stamer, J.K., eds., 1991, Surface water-quality assessment of the lower Kansas River Basin, Kansas and Nebraska-Analysis of available data through 1986: U.S. Geological Survey Open-File Report 91-75, 172 p.

Juracek, K.E., Kenny, J.F., and Perry, C.A., 1992, Herbicides, water quality and you: U.S.
Geological Survey Open-File Report 92-127, video.

Kansas Department of Health and Environment, 1987, Water quality implications of chlordane in Kansas: Topeka, Bureau of Water Protection, Division of Environment, February 1987, 25 p. 1988a, 1987 Regional ambient fish tissue monitoring program (RAFTMP)-Report/ Summary: Topeka, Water Quality Assessment Section, Bureau of Water Protection, July 1988, $12 \mathrm{p}$. 1988b, 1987 State EPA agreement fish tissue analysis-Kansas target lakes study-Report/ Summary: Topeka, Water Quality Assessment Section, Bureau of Water Protection, December $1988,17 \mathrm{p}$.

Kansas Geological Survey, 1964, Geologic map of Kansas: Kansas Geological Survey Map Series M-1, 1 sheet, scale 1:500,000.

Kansas State Board of Agriculture, 1988, Kansas farm facts 1987: Topeka, Kansas, 110 p. 1989, Kansas farm facts, 1988: Topeka, Kansas, $110 \mathrm{p}$. 1990, Kansas farm facts 1989: Topeka, Kansas, $112 \mathrm{p}$.

Kansas State University, 1991, Kansas agricultural chemical usage-1990 corn and soybean summary: Manhattan, Kansas State University Cooperative Extension Service, 28 p.

Leahy, P.P., Rosenshein, J.S., and Knopman, D.S., 1990, Implementation plan for the National WaterQuality Assessment Program: U.S. Geological Survey Open-File Report 90-174, 10 p.

Lowe, T.P., May, T.W., Brumbaugh, W.G., and Kane, D.A., 1985, National contaminant biomonitoring program-Concentrations of seven elements in freshwater fish, 1978-1981: Archives of Environmental Contamination and Toxicology, v. 14, p. $363-388$.

McKinney, R.E., 1962, Microbiology for sanitary engineers: New York, McGraw-Hill Inc., 153 p.

National Academy of Sciences, 1969, Eutrophication, causes, consequences, and corrections: Washington, D.C., $651 \mathrm{p}$.

National Academy of Sciences and National Academy of Engineering, 1973, Water quality criteria, 1972: U.S. Environmental Protection Agency Ecological Research Series EPA/R3/73/033, $594 \mathrm{p}$.

National Oceanic and Atmospheric Administration, 1951-80, Climatological data, Kansas, annual sum- mary: Asheville, N.C., National Climatic Center, published annually. 1987-90, Climatological data, Kansas: Asheville, N.C., National Climatic Center, published monthly. 
Nebraska Agricultural Statistics Service, 1988, 1987

Nebraska agricultural statistics: Lincoln, 120 p. 1989, 1988 Nebraska agricultural statistics:

Lincoln, $126 \mathrm{p}$.

1990, 1989 Nebraska agricultural statistics:

Lincoln, 154 p.

Parker, R.L., 1967, Composition of the Earth's crust, in Fleischer, Michael, ed., Data of geochemistry (6th ed.): U.S. Geological Survey Professional Paper 440-D, $19 \mathrm{p}$.

Peterjohn, W.T., and Correll, D.L., 1984, Nutrient dynamics in an agricultural watershedObservations on the role of a riparian forest: Ecology, v. 65, no. 5, p. 1466-1475.

Reid, G.K., and Wood, R.D., 1976, Ecology of inland waters and estuaries: New York, D. Van Nostrand Co., $485 \mathrm{p}$.

Ritter, D.F., 1978, Process geomorphology: Dubuque, Iowa, William C. Brown Co. Publ., 601 p.

Robertson, J.K., and Wojciechowski, Dorothea, eds., 1986a, Directory of precipitation monitoring sites-National Atmospheric Deposition Program/ National Trends Network (NADP/NTN): West Point, New York, National Acid Precipitation Assessment Program, vol. 1, unnumbered pages. 1986b, Directory of precipitation monitoring sites-National Atmospheric Deposition Program/ National Trends Network (NADP/NTN): West Point, New York, National Acid Precipitation Assessment Program, vol. 2, unnumbered pages.

Ryder, J.L., and Sanzolone, R.F., 1989, Statistical summaries of elemental constituents in streambed sediments in the lower Kansas River Basin, Nebraska, Kansas, and Missouri: U.S. Geological Survey Open-File Report 89-110, 28 p.

Sanzolone, R.F., and Ryder, J.L., 1989, Quality control procedures and results for the bed-sediment materials of the surface-water pilot studies of the National Water Quality-Assessment Program: U.S. Geological Survey Open-File Report 89-658, 22 p.

Schertz, T.L., Alexander, R.B., and Ohe, D.J., 1991, The computer program EStimateTREND (ESTREND), a system for the detection of trends in water-quality data: U.S. Geological Survey Water-Resources Investigations Report 91-4040, 63 p.

Seaber, P.R., Kapinos, F.P., and Knapp, G.L., 1984, State hydrologic unit maps: U.S. Geological Survey Open-File Report 84-708, 198 p.

Shacklette, H.T., and Boerngen, J.G., 1984, Elemental concentrations in soils and other surficial materials of the conterminous United States: U.S.

Geological Survey Professional Paper 1270, 105 p.
Simons, $\mathrm{Li}$, and Associates, Inc., 1984, Analysis of channel degradation and bank erosion in the lower Kansas River: Kansas City, Mo., U.S. Army Corps of Engineers, DACW 41-83-C-01, unnumbered pages.

Smith, J.A., Witkowski, P.J., and Fusillo, T.V., 1988, Manmade organic compounds in the surface waters of the United States-A review of current understanding: U.S. Geological Survey Circular 1007, $92 \mathrm{p}$.

Stamer, J.K., 1991a, pH, alkalinity, and acidity, in Jordan, P.R., and Stamer, J.K., eds., Surface waterquality assessment of the lower Kansas River Basin, Kansas and Nebraska-Analysis of available data through 1986: U.S. Geological Survey Open-File Report 91-75, p. 34-41. 1991b, Dissolved oxygen and biochemical oxygen demand, in Jordan, P.R., and Stamer, J.K., eds., Surface water-quality assessment of the lower Kansas River Basin, Kansas and NebraskaAnalysis of available data through 1986: U.S. Geological Survey Open-File Report 91-75, p. 101-111.

1991c, Radionuclides, in Jordan, P.R., and Stamer, J.K., eds., Surface water-quality assessment of the lower Kansas River Basin, Kansas and NebraskaAnalysis of available data through 1986: U.S. Geological Survey Open-File Report 91-75, p. 133.

1991d, Organic carbon, in Jordan, P.R., and Stamer, J.K., eds., Surface water-quality assessment of the lower Kansas River Basin, Kansas and Nebraska-Analysis of available data through 1986: U.S. Geological Survey Open-File Report 91-75, p. 134-137.

Stamer, J.K., and P.R. Jordan, 1991, Nutrients, in Jordan, P.R., and Stamer, J.K., eds., Surface waterquality assessment of the lower Kansas River Basin, Kansas and Nebraska-Analysis of available data through 1986: U.S. Geological Survey Open-File Report 91-75, p. 78-100.

Stamer, J.K., Jordan, P.R., Engberg, R.A., and Dugan, J.T., 1987, Surface-water-quality assessment of the lower Kansas River Basin, Kansas and NebraskaProject description: U.S. Geological Survey Open-File Report 87-105, 36 p.

Stamer, J.K., Pope, L.M., and Zelt, R.B., 1990, Occurrence and distribution of pesticides in the lower Kansas River Basin: Proceedings of 7th Annual Water and the Future of Kansas Conference, Manhattan, Kansas, March 7-8, 1990, p. 25-26. 
Stamer, J.K., Sanzalone, R.F., and Ryder, J.L., 1991, Major metals and trace elements, in Jordan, P.R., and Stamer, J.K., eds., Surface water-quality assessment of the lower Kansas River Basin, Kansas and Nebraska-Analysis of available data through 1986: U.S. Geological Survey Open-File Report 91-75, p. 112-132.

Stamer, J.K., and Zelt, R.B., 1992, Distribution of atrazine and similar nitrogen-containing herbicides, lower Kansas River Basin: U.S. Geological Survey Yearbook Fiscal Year 1991, p. 76-79.

Stevens, H.H., Jr., Ficke, J.F., and Smoot, G.F., 1975, Water temperature influential factors, field measurement, and data presentation:

U.S. Geological Survey Techniques of WaterResources Investigations, book 1, chap. D1, 65 p.

Tanner, D.Q., Sanzolone, R.F., and Zelt, R.B., 1990, Surface water-quality assessment of the lower Kansas River Basin, Kansas and NebraskaConcentrations of major metals and trace elements in streambed sediments, 1987: U.S. Geological Survey Open-File Report 90-581, 73 p.

Thatcher, L.L., Janzer, V.J., and Edwards, K.W., 1977, Methods for determination of radioactive substances in water and fluvial sediments: U.S. Geological Survey Techniques of Water-Resources Investigations, book 5, chap. A5, $95 \mathrm{p}$.

Thurman, E.M., 1985, Organic geochemistry of natural waters: Dordrecht, Martinus Nijhoff/Dr. W. Junk Publishers, $497 \mathrm{p}$.

Todd, D.K., 1980, Groundwater hydrology (2d ed.): New York, John Wiley and Sons, $535 \mathrm{p}$.

Union Carbide Corporation, Nuclear Division, 1979a, Hydrogeochemical and stream sediment reconnaissance basic data for Manhattan NTMS quadrangle, Kansas: U.S. Department of Energy, Oak Ridge Gaseous Diffusion Plant, report GJBX-134(79), 149 p.

1979b, Hydrogeochemical and stream sediment reconnaissance basic data for Hutchinson NTMS quadrangle, Kansas: U.S. Department of Energy, Oak Ridge Gaseous Diffusion Plant, report GJBX-133(79), $150 \mathrm{p}$.

1980, Hydrochemical and stream sediment reconnaissance basic data for Grand Island NTMS quadrangle, Nebraska: U.S. Department of Energy, Oak Ridge Gaseous Diffusion Plant, report GJBX-185(80), 138 p.

1981a, Hydrogeochemical and stream sediment reconnaissance basic data for Lincoln NTMS quadrangle, Nebraska: U.S. Department of Energy, Oak Ridge Gaseous Diffusion Plant, report GJBX-229(81), 131 p. 1981b, Hydrogeochemical and stream sediment reconnaissance basic data for Fremont NTMS quadrangle, Nebraska; Iowa: U.S. Department of Energy, Oak Ridge Gaseous Diffusion Plant, report GJBX-392(81), 124 p.

U.S. Army Corps of Engineers, 1972, Sedimentation in Kanopolis Reservoir, Smoky Hill River, Kansas: Kansas City, Mo., Department of the Army, Kansas City District, Corps of Engineers, $37 \mathrm{p}$.

U.S. Bureau of the Census, 1989a, 1987 Census of agriculture, Kansas state and county data: Washington, D.C., geographic area series, v. 1, pt. $16,499 \mathrm{p}$.

1989b, 1987 Census of agriculture, Nebraska state and county data: Washington, D.C., geographic area series, v. 1, pt. 27, $468 \mathrm{p}$.

1991a, 1990 Census of population and housing Public Law 94-171 data-Nebraska: Washington, D.C., U.S. Bureau of the Census, compact disc. 1991b, 1990 Census of population and housingPublic Law 94-171 data-Kansas: Washington, D.C., U.S. Bureau of the Census, compact disc.

U.S. Department of Agriculture, 1991a, Agricultural chemical usage, 1990 field crops summary: Washington, D.C., National Agricultural Statistical Service, Economics Research Service, 154 p. 1991b, Agricultural resources, inputs, situation and outlook report: Washington, D.C., National Agricultural Statistics Service, Economic Research Service, AR-21, $54 \mathrm{p}$.

U.S. Environmental Protection Agency, 1978, Quality criteria for water, July 1976: Washington, D.C., Office of Water and Hazardous Materials, $256 \mathrm{p}$. 1985a, Test methods for Escherichia coli and Enterococci in water by the membrane filter procedure: Washington, D.C., U.S. Environmental Protection Agency, EPA 600/4-85/076, 12 p. 1985b, Suspended, canceled, and restricted pesticides: Washington, D.C., U.S. Environmental Protection Agency Office of Pesticides and Toxic Substances Compliance and Monitoring Staff (EN-342), 29 p.

1986, Maximum contaminant levels (subpart B of part 141, National interim primary drinking- water regulations): U.S. Code of Federal Regulations, Title 40, Parts 100 to 149 , revised as of July 1 , 1986, p. 524-528. 1987, Quality criteria for water 1986: Washington, D.C., Office of Water Regulations and Standards, EPA 440/5-86-001, unnumbered pages (1986 publication with 1987 updates). 1989, Drinking water health advisory-Pesticides: Chelsea, Mich., Lewis Publ., Inc., 819 p. 
1990, Fact sheet-Drinking water regulations under the Safe Drinking Water Act: Washington, D.C., Office of Drinking Water, $43 \mathrm{p}$. 1991, Organic chemicals other than total trihalomethanes, sampling and analytical requirements (section 141.24 of part 141, national primary drinking-water regulations): U.S. Code of Federal Regulations, Title 40, Parts 100-149, revised as of January 30, 1991, p. 3583-3587.

1992, Drinking water regulations and health advisories: Washington, D.C., Office of Water, $13 \mathrm{p}$.

U.S. Food and Drug Administration, 1989, FDA compliance policy guides manual, chap. 41Pesticides attachment B.3: Washington, D.C., Office of Enforcement, CPG 7141.01-B.3, 3 p.

Van Dyne, D.L., and Gilbertson, C.B., 1978, Estimating U.S. livestock and poultry manure and nutrient production: U.S. Department of Agriculture, Economics, Statistics, and Cooperative Service, ESCS-12, $150 \mathrm{p}$.

Vanoni, V.A., 1975, Sedimentation engineering: American Society of Civil Engineers, Manuals and Reports on Engineering Practice No. 54, 745 p.

Ward, J.R., and Harr, C.A., eds., 1990, Methods for collection and processing of surface-water and bed-material samples for physical and chemical analyses: U.S. Geological Survey Open-File Report 90-140, 71 p.

Wershaw, W.L., Fishman, M.J., Grabbe, R.R., and Lowe, L.E., 1987, Methods for the determination of organic substances in water and fluvial sediments: U.S. Geological Survey Techniques of Water-Resources Investigations, book 5, chap. A3, $80 \mathrm{p}$.

Williams, D.L., and Barker, B.L., 1974, Kansas land-use map, summer 1973: Kansas Department of Economic Development, 1 sheet, scale $1: 1,000,000$.

Wischmeier, W.H., and Smith, D.D., 1965, Predicting rainfall-erosion losses from cropland east of the Rocky Mountains: U.S. Agricultural Research Service, Agriculture Handbook 282, 47 p.

Wolf, R.J., and Helgesen, J.O., 1992, Ground- and surface-water interaction between the Kansas River and associated alluvial aquifer, northeastern Kansas: U.S. Geological Survey Water-Resources Investigations Report 92-4137, $49 \mathrm{p}$.

Zelt, R.B., 1991, GIS technology used to manage and analyze hydrologic information: GIS World, August 1991, p. 70-73. 



\section{Periodicals}

Earthquakes \& Volcanoes (issued bimonthly).

Preliminary Determination of Epicenters (issued monthly).

\section{Technical Books and Reports}

Professional Papers are mainly comprehensive scientific reports of wide and lasting interest and importance to professional scientists and engineers. Included are reports on the results of resource studies and of topographic, hydrologic, and geologic investigations. They also include collections of related papers addressing different aspects of a single scientific topic.

Bulletins cortain significant data and interpretations that are of lasting scientific interest but are generally more limited in scope or geographic coverage than Professional Papers. They include the results of resource studies and of geologic and topographic investigations, as well as collections of short papers related to a specific topic.

Water-Supply Papers are comprehensive reports that present significant interpretive results of hydrologic investigations of wide interest to professional geologists, hydrologists, and engineers. The series covers investigations in all phases of hydrology, including hydrogeology, availability of water, quality of water, and use of water.

Circulars present administrative information or important scientific information of wide popular interest in a format designed for distribution at no cost to the public. Information is usually of short-term interest.

Water-Resources Investigations Reports are papers of an interpretive nature made available to the public outside the formal USGS publications series. Copies are reproduced on request unlike formal USGS publications, and they are also available for public inspection at depositories indicated in USGS catalogs.

Open-File Reports include unpublished manuscript reports, maps, and other material that are made available for public consultation at depositories. They are a nonpermanent form of publication that may be cited in other publications as sources of information.

\section{Maps}

Geologic Quadrangle Maps are multicolor geologic maps on topographic bases in 7.5- or 15-minute quadrangle formats (scales mainly $1: 24,000$ or $1: 62,500$ ) showing bedrock, surficial, or engineering geology. Maps generally include brief texts; some maps include structure and columnar sections only.

Geophysical Investigations Maps are on topographic or planimetric bases at various scales; they show results of surveys using geophysical techniques, such as gravity, magnetic, seismic, or radioactivity, which reflect subsurface structures that are of economic or geologic significance. Many maps include correlations with the geology.

Miscellaneous Investigations Series Maps are on planimetric or topographic bases of regular and irregular areas at various scales; they present a wide variety of format and subject matter. The series also includes 7.5-minute quadrangle photogeologic maps on planimetric bases that show geology as interpreted from aerial photographs. Series also includes maps of Mars and the Moon.
Coal Investigations Maps are geologic maps on topographic or planimetric bases at various scales showing bedrock or surficial geology, stratigraphy, and structural relations in certain coalresource areas.

Oil and Gas Investigations Charts show stratigraphic information for certain oil and gas fields and other areas having petroleum potential.

Miscellaneous Field Studies Maps are multicolor or blackand-white maps on topographic or planimetric bases for quadrangle or irregular areas at various scales. Pre-1971 maps show bedrock geology in relation to specific mining or mineral-deposit problems; post-1971 maps are primarily black-and-white maps on various subjects such as environmental studies or wilderness mineral investigations.

Hydrologic Investigations Atlases are multicolored or black-and-white maps on topographic or planimetric bases presenting a wide range of geohydrologic data of both regular and irregular areas; principal scale is 1:24,000, and regional studies are at $1: 250,000$ scale or smaller.

\section{Catalogs}

Permanent catalogs, as well as some others, giving comprehensive listings of U.S. Geological Survey publications are available under the conditions indicated below from the U.S. Geological Survey, Information Services, Box 25286, Federal Center, Denver, CO 80225. (See latest Price and Availability List.)

"Publications of the Geological Survey, 1879-1961" may be purchased by mail and over the counter in paperback book form and as a set of microfiche.

"Publications of the Geological Survey, 1962-1970" may be purchased by mail and over the counter in paperback book form and as a set of microfiche.

"Publications of the U.S. Geological Survey, 1971-1981" may be purchased by mail and over the counter in paperback book form (two volumes, publications listing and index) and as a set of microfiche.

Supplements for 1982, 1983, 1984, 1985, 1986, and for subsequent years since the last permanent catalog may be purchased by mail and over the counter in paperback book form.

State catalogs, "List of U.S. Geological Survey Geologic and Water-Supply Reports and Maps For (State)," may be purchased by mail and over the counter in paperback booklet form only.

"Price and Availability List of U.S. Geological Survey Publications," issued annually, is available free of charge in paperback booklet form only.

Selected copies of a monthly catalog "New Publications of the U.S. Geological Survey" are available free of charge by mail or may be obtained over the counter in paperback booklet form only. Those wishing a free subscription to the monthly catalog "New Publications of the U.S. Geological Survey" should write to the U.S. Geological Survey, 582 National Center, Reston, VA 22092.

Note-Prices of Government publications listed in older catalogs, announcements, and publications may be incorrect. Therefore, the prices charged may differ from the prices in catalogs, announcements, and publications. 